INSTITUTO DE PESQUISAS ENERGÉTICAS E NUCLEARES AUTARQUIA ASSOCIADA À UNIVERSIDADE DE SÃO PAULO

Avaliação do Ciclo de Vida de Potenciais Rotas de Produção de Hidrogênio: Estudo dos Sistemas de Gaseificação da Biomassa e de Energia Solar Fotovoltaica

Sandra Harumi Fukurozaki

Tese apresentada como parte dos requisitos para a obtenção do Grau de Doutor em Ciências na Área de Tecnologia Nuclear Materiais

Orientador: Dr. José Octavio Armani Paschoal

São Paulo 
Ao meu pai, de quem eu herdei os infindáveis por quês. 
Das primeiras idéias para um projeto de pesquisa até a concretização desta tese, além do suporte institucional, diversas pessoas colaboraram nas diferentes etapas do doutorado.

Partindo do lado institucional, agradeço ao Conselho Nacional de Pesquisa e Desenvolvimento - CNPq, pela bolsa concedida no Brasil e durante o doutorado sanduíche nos Estados Unidos. Ao Instituto de Pesquisas Energéticas e Nucleares - IPEN, por propiciar a realização desta pesquisa e a Universidade da Califórnia/ Merced - UC Merced, pela oportunidade de aperfeiçoamento.

Das pessoas que contribuíram, indireta ou diretamente, registro meu prazer em agradecer, a começar pelo Prof. Dr. José Octavio Armani Paschoal, "Honorável orientador", pela convivência construtiva, marcada pela orientação e instrução ímpar. Em especial, pela compreensão diante dos meus intermináveis questionamentos e pelas palavras de incentivo no decorrer da minha temporada no exterior.

Ao Prof. Dr. Carlos F. M. Coimbra, da UC Merced, Mechanical Engineering Department, por agregar novas abordagens ao projeto de doutorado e pela experiência de trabalho em um ambiente de pesquisa excepcional. A MSc. Kaori Coimbra pela hospitalidade e pelo auxílio nos meus primeiros dias na ensolarada Califórnia. A Sheryl Wyan, do Academic Affairs, pela recepção calorosa e conselhos.

A Dra. Cecília Makishi da Universidade de Stuttgart/Ganzheitliche Bilanzierung (GaBi) por me apresentar ao Gerente de Projeto - Life Cycle Engineering, Michael Held, que disponibilizou seu tempo e atenção, durante o $24^{\text {th }}$ PVSEC em Hamburg, em sanar todas minhas dúvidas relacionadas a avaliação do ciclo de vida em energia solar fotovoltaica e, por fornecer informações sobre o inventário do Projeto Crystal Clear.

A Dra. Martha Mora Bejarano, da Enfil S/A, pelas recomendações e sugestões que muito contribuíram para aprimorar o trabalho, em especial pela amizade e 
atenção, inclusive de madrugada, em esclarecer desde questões relacionadas aos sistemas de gaseificação até as filosóficas.

Aos professores da Universidade de São Paulo - EACH, do curso de Gestão Ambiental, Dra. Cristina Adams, pela supervisão durante o Programa de Aperfeiçoamento de Ensino (PAE) e com quem eu tive uma experiência única de aprendizado. Cris, muito obrigada pelo estímulo, apoio e confiança. Ao Dr. Astolfo A. Mello pela troca de idéias e discussões em torno da questão ambiental e recomendações.

Ao professor Dr. Eric Boria pela inestimável ajuda, que iniciou-se na visita a Universidade de Wisconsin, à acomodação em Merced, incluindo revisões de texto e as boas risadas. Eric, I am grateful for your friendship and support.

Aos amigos do IPEN, Dr. Ajibola Isau Badiru, pelas discussões sobre sustentabilidade, os cafés e devaneios acadêmicos. Á MSc. Maria Cecília, pela amizade, as horas de descontração e, principalmente, pelo grande apoio nos momentos de transição.

Aos colegas do Solar Energy Laboratory da UC Merced, David Brown, pelas informações e dados fornecidos. Ao David Larson e Dra. Lynnete Ramirez por me auxiliarem das mais diversas formas, dentro e fora da universidade. Em particular, agradeço ao engenheiro ambiental Ricardo Marques pelos debates, algumas vezes acalorados, sobre energia e meio ambiente, pelas opiniões, livros e materiais compartilhados. Ricardo and Rhonda, I am thankful for all your help!

Aos colegas do Computer Science Engineering Department, Chao Quin e Jian Wu pela amizade e companhia alegre no retorno da UC para casa e, principalmente, pela assistência e atenção no estágio final do doutorado sanduíche. Thank you guys for your friendship and companionship.

Á Donilia Martins, por se deslocar de tão longe para me ajudar e pelos lanches da tarde, recheados de pão de queijo, tortas e bolos. 
A minha família querida, pela qual manifesto eterna gratidão. Living in United States was a big step and I could not have done it without them. Aos meus pais pelo apoio constante e incondicional, a Sayuri e Mayumi, que me auxiliaram desde os primeiros contatos e visitas às universidades nos Estados Unidos até o retorno ao Brasil, a Sumié e Kozué pelas duas mãozinhas na digitação e formatação de tabelas e figuras, principalmente, pelas guloseimas que tornaram minhas madrugadas mais alegres.

Por fim, but not ever, ever the least, ao Miguel, o contrapeso da minha balança. Obrigada pela paciência, parceria e brincadeiras no decorrer do meu doutorado. 
When the fuel cell is becoming the automotive engine choice in the automotive industry, those companies focused on increasing the performance and efficiency of the internal combustion engine might themselves left behind. It is time to keep making what are making? Or is it time to create a new niche? Innovation requires noticing signals outside the company itself: signals in the community, the environment, and the word at large. Be open to "feedforwad", not just to feedback ${ }^{1}$.

${ }^{1}$ Willian McDonough \& Michael Braungart, Remaking the Way We Make Things: Cradle to Cradle, p.184. 


\title{
AVALIAÇÃO DO CICLO DE VIDA DE POTENCIAS ROTAS DE PRODUÇÃO DE HIDROGÊNIO: ESTUDO DOS SISTEMAS DE GASEIFICAÇÃO DA BIOMASSA E DE ENERGIA SOLAR FOTOVOLTAICA:
}

\author{
SANDRA HARUMI FUKUROZAKI
}

\begin{abstract}
RESUMO
No presente trabalho, o desempenho energético e ambiental de potencias rotas de produção de hidrogênio - gaseificação da biomassa via leito fixo (LFX) e leito fluidizado (LFL) e de energia solar fotovoltaica - foram estudados com base na metodologia de Avaliação do Ciclo de Vida (ACV). Após a revisão da literatura e a descrição dos procedimentos de análise, os resultados da ACV são apresentados e discutidos em termos de Demanda Acumulada de Energia (CED), Tempo de Retorno de Investimento em Energia (EPBT) e danos relacionados à Saúde Humana (SH), Qualidade do Ecossistema (QE) e Recursos Minerais e Combustíveis Fósseis (RMCF). No cômputo geral, o LFL é mais favorável para a produção de hidrogênio, embora os dois sistemas de gaseificação apresentem desempenho energético e ambiental similares. Comparativamente, o sistema fotovoltaico apresenta um EPBT maior (4,55 anos) do que os encontrados nos dois sistemas de conversão da biomassa (1,65 anos no LFL e 1,77 anos no LFX). Por outro lado, o sistema de energia solar fotovoltaico é o mais ambientalmente recomendável para a produção de hidrogênio, tendo em vista a menor contribuição em relação aos danos majoritários (saúde humana). Dentro do escopo do estudo, os sistemas avaliados apresentam mais características de complementaridade do que competição. Neste caso, enfatiza-se a importância de uma análise dos fatores econômicos e sociais pertinentes a cada país ou região, bem como dos processos posteriores de reforma e/ou purificação e eletrólise da água, considerando também o seu inteiro ciclo de vida.
\end{abstract}

Palavras chaves: avaliação do ciclo de vida, hidrogênio, sistemas de gaseificação, energia solar fotovoltaica, desempenho energético e ambiental. 


\title{
LIFE CYCLE ASSESSMENT OF HYDROGEN PRODUCTION ROUTES: STUDY OF GASEIFICATION SYSTEMS AND PHOTOVOLTAIC SOLAR POWER
}

\author{
SANDRA HARUMI FUKUROZAKI
}

\begin{abstract}
In the present study, the energy and environmental performance of hydrogen potential routes - biomass gasification systems by fixed bed and fluidized bed and the solar photovoltaic power plant - were studied based on Life Cycle Assessment (LCA) methodology. After reviewing the literature and analytical procedures description, the results of life cycle assessment are discussed in terms of Cumulative Energy Demand (CED), Energy Payback Time (EPBT) and damages related to Human Health (SH), Ecosystem Quality (QE) and Mineral and Fossil Fuels Resources (RMCF). Although the two gasification systems have similar energy and environmental performance, the LFL is more favorable for hydrogen production. Regarding the photovoltaic system, this has a greater EPBT (4.55 years) than those found in the two systems of biomass conversion (1.65 and 1.77 years in the LFL and $L F X$, respectively). On the other hand, the solar photovoltaic system is the more environmentally suitable for hydrogen production, since its contribution related to human health impact is smaller than gasification systems. Within the scope of the study, the evaluated systems have more features of complementarities than competition. In this case, we emphasize the importance of analyzing the economic and social factors that are relevant in each country or region, as well as the subsequent process for hydrogen production (purification and water electrolysis) also considering the entire life cycle of systems.
\end{abstract}

Key words: life cycle assessment, hydrogen, gasification systems, solar PV, energy and environmental performance. 
Figura 1.1 - Cadeia de produção de energia a partir da extração - topo - até os serviços base.

Figura 1.2 - Participação das fontes de energia na matriz energética mundial e no Brasil. 26

Figura 2.1 - Diagrama básico das rotas convencionais de produção de hidrogênio.

Figura 2.2 - Diagrama básico das rotas alternativas de produção de hidrogênio.

Figura 2.3 - Gaseificação da biomassa e produção de combustíveis, eletricidade e calor. 40

Figura 2.4 - Diagrama esquemático da síntese de combustíveis e produtos químicos a partir do syngas.

Figura 2.5 - Produção de hidrogênio solar.

Figura 2.6 - Diagrama esquemático da integração de um sistema FV e de produção de hidrogênio.

Figura 3.1 - Diagrama esquemático dos processos de conversão energética da biomassa.

Figura 3.2 - Gaseificador de leito fixo, fluxo ascendente ou contracorrente.

Figura 3.3 - Gaseificador de leito fixo, fluxo descendente ou concorrente.

Figura 3.4 - Tipos de gaseificadores e escala típica da capacidade de alimentação.

Figura 3.5 - Gaseificador de leito fluidizado.

Figura 4.1 - Conversão da energia solar em eletricidade por meio de células solares fotovoltaicas.

Figura 4.2 - Reflexão da radiação solar na atmosfera conduzindo a irradiação difusa.

Figura 4.3 - Média anual da irradiação global horizontal no Brasil.

Figura 4.4 - Efeito fotovoltaico na junção pn.

Figura 4.5 - Diagrama das atuais tecnologias de energia solar fotovoltaica disponíveis.

Figura 4.6 - Planta Solar Fotovoltaica de10 MWp, on grid.

Figura 4.7 - Sistema Solar Fotovoltaico de 203 kWp, tipo telhado.

Figura 4.8 - Sistema Solar Fotovoltaico de 71,5 kWp, tipo fachada.

Figura 4.9 - Planta. Solar Fotovoltaico de 4,2 MW, off grid.

Figura 4.10 - Sistema. Solar Fotovoltaico autônomo, off grid, tipo telhado. 
Figura 4.11- Percentual de participação das diferentes tecnologias no mercado fotovoltaico.

Figura 5.1 - Ilustração simplificada da abordagem da Avaliação do Ciclo de Vida

Figura 5.2 - Estrutura conceitual do ciclo de vida e da metodologia ACV

Figura 5.3 - Exemplo de um diagrama simplificado para ACV de um modelo de sistema técnico - produção de biomassa e transporte

Figura 5.4 - Exemplo simplificado de uma avaliação de impacto do ciclo de vida

Figura 5.5 - Tipos de pacotes de softwares de ACV

Figura 5.6 - Software de Avaliação do Ciclo de Vida - Gabi 4.

Figura 5.7 - Estrutura conceitual da metodologia do Eco-indicator 99

Figura 5.8 - Exemplo da curva do PAF em função da exposição de uma dada $s p$ a determinadas concentrações.

Figura 5.9 - Triangle tool.

Figura 5.10 - Linha de indiferença dentro do Triangle tool e as sub áreas.

Figura 6.1 - Exemplo de um esquema de instalação de um gaseificador de biomassa - leito fixo contracorrente.

Figura 6.2 - Exemplo de um esquema de instalação de um gaseificador de biomassa - leito fluidizado circulante.

Figura 6.3 - Diagrama esquemático de uma célula SOFC operando com um gaseificador de biomassa.

Figura 6.4 - Diagrama simplificado das atividades e processos incluídos nos limites dos sistemas de gaseificação estudados.

Figura 6.5 - Produção de lascas de madeira a partir dos resíduos da construção e demolição e suprimento de lascas de madeira para a planta de gaseificação.

Figura 6.6 - Diagrama do processo de limpeza do gás úmido em baixa temperatura.

Figura 6.7 - Demanda Acumulada de Energia $\left(C E D=E_{0}\right)$ dos sistemas de gaseificação estudados (valor líquido calorífico em MJ)

Figura 6.8 - CED das variáveis independentes do tempo (CED, $E_{0}$ ), CED das variáveis dependentes do tempo - Energia auxiliar $\left(E_{U}, E_{A}\right)$ e Transporte $\left(E_{U}, F\right)$.

Figura 6.9 - Contribuição relativa dos danos a SH, QE e RMCF dos sistemas LFL e LFX (\%). 
Figura 6.10 - Contribuição relativa (mudanças climáticas e efeitos respiratórios inorgânicos) dos sistemas de LFL e LFX na categoria de danos a saúde humana (\%).

Figura 6.11 - Contribuição relativa (acidificação/eutrofização e ecotoxicidade) dos sistemas de LFL e LFX na categoria de danos a qualidade do ecossistema (\%).

Figura 6.12 - Comparação do desempenho ambiental entre o sistema de gaseificação LFX e o LFL.

Figura 6.13 - Planta Solar Fotovoltaica de $1 \mathrm{MW}$ da Universidade da Califórnia - UC Merced (2009).

Figura 6.14 - Diagrama simplificado de um sistema de energia solar fotovoltaico (modificado a partir de Sumco Corporation, 2010)

Figura 6.15 - Diagrama ilustrando a relação entre as células (1) o módulo (2), painel (3) e o arranjo (4) do sistema FV (modificado a partir de PRASAD \&SNOW,2005).

Figura 6.16 - Diagrama simplificado dos processos incluídos nos limites do sistema de energia solar fotovoltaico estudado.

Figura 6.17 - Diagrama simplificado do processo de produção do silício monocristalino pelo método Czochralski .

Figura 6.18 - Diagrama simplificado do processo de produção de lâminas de silício monocristalino.

Figura 6.19 - llustração do processo de produção de células até a montagem do painel fotovoltaico (modificado a partir de Sumco Corporation, 2010).

Figura 6.20 - Exemplo de inversor para plantas fotovoltaicas com geração de energia acima de $500 \mathrm{~kW}$.

Figura 6.21 - Demanda Acumulada de Energia do sistema fotovoltaico (valor calorífico líquido em TJ).

Figura 6.22 - Demanda Acumulada de Energia de cada processo produtivo do sistema FV (valor calorífico liquido em TJ).

Figura 6.23 - Contribuição relativa dos danos a SH, QE e RMCF do sistema FV (percentual de participação) 
Figura 6.24 - Contribuição relativa de cada processo produtivo do sistema FV de danos a SH, QE e RMCF (percentual de participação).

Figura 6.25 - Contribuição relativa dos danos a SH, QE e RMCF por processo produtivo do sistema FV (percentual de participação normalizados para 100\%).

Figura 6.26 - Comparação do desempenho ambiental entre o sistema de gaseificação LFX e o sistema FV.

Figura 6.27 - Comparação do desempenho ambiental entre o sistema de gaseificação LFL e o sistema FV. 
Tabela 2.1 - Propriedades do Hidrogênio

Tabela 3.1 - Estimativa de uso de energia da biomassa no suprimento global de energia no futuro (EJ)

Tabela 3.2 - Mudança de energia nas reações de conversão térmica estimadas para celulose.

Tabela 4.1 - Potencial de contribuição das tecnologias de energia solar

Tabela 5.1 - Exemplo de valores típicos das três perspectivas de análise do Eco-indicator 99.

Tabela 5.2 - Média dos fatores de danos, normalização e ponderação na perspectiva hieraquista.

Tabela 5.3 - Exemplo dos resultados da AICV com suas respectivas contribuições relativas e valores agregados.

Tabela 6.1 - Composição típica da biomassa (lascas de madeira), percentual de umidade (u) e demais características utilizadas no estudo.

Tabela 6.2 - Dados das unidades do processo das diferentes misturas de lascas de madeira utilizadas no estudo e respectivas quantidades e valores.

Tabela 6.3 - Características dos gaseificadores.

Tabela 6.4 - Sumário do quantidade de calor e eletricidade requerida no sistema de gaseificação de leito fixo e leito fluidizado.

Tabela 6.5 - Composição típica do gás de síntese em leito fixo e leito fluidizado.

Tabela 6.6 - Dados das unidades de processo da planta de gaseificador de leito fixo (1MW) utilizadas no estudo e respectivas quantidades e tipo de fluxo.

Tabela 6.7 - Dados das unidades de processo da planta de gaseificador de leito fluidizado (1MW) utilizadas no estudo e respectivas quantidades e tipo de fluxo.

Tabela 6.8 - Síntese das principais emissões atmosféricas (orgânicas e inorgânicas) dos sistemas de gaseificação estudados.

Tabela 6.9 - CED das variáveis independentes do tempo ( CED, $E_{0}$ ).

Tabela 6.10 - CED das variáveis independentes $\left(E_{O}\right)$ e independentes $\left(E_{U} / E_{A}, E_{F}\right)$ do tempo, CED integrada $\left(E_{0}, E_{U}\right)$, Produção Anual Líquida (PAE) e Tempo de Retorno de Investimento em Energia (EPBT) dos sistemas de gaseificação LFX e LFL.

Tabela 6.11 - Contribuição relativa dos diferentes parâmetros utilizados na avaliação de impacto e valor agregado por categoria de dano (\%) dos si temas LFL e LFX. 
Tabela 6.12 - Dados das unidades de processo da produção mix de silício purificado com respectivas quantidades e unidades de medidas. .

Tabela 6.13 - Dados das unidades de processo da produção de silício monocristalino (método CZ) e respectivas referências de quantidades.

Tabela 6.14 - Dados das unidades de processo da produção de lâminas de silício monocristalino e respectivas referências de quantidades.

Tabela 6.15 - Dados das unidades de processo da produção das células solares de Si-sc e respectivas referências de quantidades.

Tabela 6.16 - Dados das unidades de processo da produção dos painéis solares de Si-sc e respectivas referências de quantidades.

Tabela 6.17 - Dados das unidades de processo da produção dos inversores e respectivas referências de quantidades.

Tabela 6.18 - Síntese das principais emissões atmosféricas (orgânicas e inorgânicas) do sistema solar fotovoltaico.

Tabela 6.19 - Valores absolutos e contribuição relativa dos recursos não renováveis na Demanda Acumulada de Energia do sistema FV:

Tabela 6.20 - Contribuição relativa de cada parâmetro e o valor agregado por categoria de dano do sistema FV: 


\begin{tabular}{|ll|}
\hline ACV & Avaliação do Ciclo de Vida \\
AICV & Avaliação de Impacto do Ciclo de Vida \\
BOS & Componentes Auxiliares do Sistema Fotovoltaico \\
CED & Demanda Acumulada de Energia \\
CdTe & Cadmio Telúrio \\
CIS & Cobre Indio Diselênio \\
CZ & Czochralski \\
EI 99 & Ecoindicador 99 \\
E/R & Relação de Equivalência \\
S/B & Razão entre Vapor e Massa \\
EPBT & Tempo de Retorno de Investimento em Energia \\
FV & Fotovoltaico (a) \\
GB & Gaseificação da Biomassa \\
ICV & Inventário do Ciclo de Vida \\
LFX & Leito Fixo \\
LFL & Leito Fluidizado \\
MCFC & Célula a Combustível de Carbonato Fundido \\
MWp & Megawatt pico \\
MWth & Megawatt térmico \\
NOEF & Efeito de Concentração Não Observado \\
PAE & Produção Anual Líquida \\
PAF & Fraça Potencialmente Afetada \\
PCI & Poder Calorífico Inferior \\
pCS & Peças \\
PDF & Fração Potencialmente Desaparecida \\
PEMFC & Célula a Combustível de Membrana Trocadora de Prótons \\
PPO & Probabilidade de Ocorrência \\
QE & Qualidade do Ecossistema \\
RCD & Resíduos da Construção e Demolição \\
RMCF & Recursos Minerais e Combustíveis Fósseis \\
Si-a & Silício Amorfo \\
Si-c & Silício Cristalino \\
Si- sC & Silício Monocristalino \\
Si-EG & Silício de Grau Eletrônico \\
Si-mc & Silício Multicristalino \\
Si-OG & Silício Off Grade \\
SG & Silício de Grau Solar \\
SH & Saúde Humana \\
SOFC & Célula a Combustível de Óxido Sólido \\
tkm & Toneladas transportadas por quilômetro rodado \\
& \\
& \\
\hline
\end{tabular}




\section{FUNDAMENTAÇÃO TÉORICA}

1. ENERGIA E SUSTENTABILIDADE 24

1.1 Sistemas de Energia $\quad 24$

1.2 Desenvolvimento de Sistemas de Energia Sustentável 26

1.2.1 Energia e a dimensão social 28

1.2.2 Energia e a dimensão ambiental 29

$\begin{array}{ll}\text { 1.2.1 Energia e a dimensão econômica } & \mathbf{3 0}\end{array}$

2. HIDROGÊNIO 33

2.1 Panorama geral 33

2.2 Propriedades e aplicações do hidrogênio 34

2.3 Produção industrial 35

2.4 Rotas de produção energética 38

3. BIOMASSA 48

3.1 Recurso e potencial de energético 48

3.2 Processos termoquímicos $\mathbf{5 2}$

3.2.1. Princípios de funcionamento da gaseificação e pirólise 5

3.2.3 Tecnologias de conversão $\quad \mathbf{5 5}$

3.3.1 Gaseificadores de leito fixo 56

$\begin{array}{ll}\text { 3.3.2 Gaseificadores de leito fluidizado } & \mathbf{6 0}\end{array}$

$\begin{array}{lll}3.4 & \text { Variáveis econômicas } & 62\end{array}$

3.5 Impactos ambientais $\quad 62$

4. ENERGIA SOLAR FOTOVOLTAICA 64

4.1 Recurso e potencial de energético 65

$\begin{array}{lll}4.2 & \text { Características do sistema fotovoltaico } & 70\end{array}$

$\begin{array}{ll}\text { 4.2.1 Tecnologias de conversão } & 71\end{array}$

4.2.2 Tamanhos da instalação e tipos de aplicações $\quad 73$

$\begin{array}{lll}4.3 & \text { Variáveis econômicas } & 76\end{array}$

$\begin{array}{lll}4.4 & \text { Impactos ambientais } & 79\end{array}$ 


\section{METODOLOGIA}

5. Visão Geral $\quad 82$

5.1 Avaliação do Ciclo de Vida: modelo conceitual 83

$\begin{array}{lll}5.2 & \text { Inventário do Ciclo de Vida } & \mathbf{8 7}\end{array}$

$\begin{array}{lll}5.3 & \text { Análise do Balanço Energético } & \mathbf{8 9}\end{array}$

5.3.1 Demanda Acumulada de Energia $\quad \mathbf{8 9}$

5.3.2 Tempo de Retorno de Investimento em Energia 94

5.4 Contabilidade dos fluxos de entrada e saída do sistema 97

5.5 Metodologia de Avaliação de Impactos Ambientais 99

5.5.1 Categoria de danos: saúde humana 100

5.5.2 Categoria de danos: qualidade do ecossistema 101

5.5.3 Categoria de danos: recursos minerais e combustíveis fósseis 103

5.5.4 Normalização 106

$\begin{array}{lll}\text { 5.5.5 Ponderação } & 108\end{array}$

$\begin{array}{lll}5.6 & \text { Interpretação dos resultados } & 111\end{array}$

\section{RESULTADOS E DISCUSSÕES}

6. Avaliação do Ciclo de Vida dos Sistemas de Gaseificação e Energia Solar Fotovoltaica

6.1 Sistemas de Gaseificação $\quad 113$

6.1.1 Objetivo, Escopo e Unidade Funcional 113

$\begin{array}{ll}\text { 6.1.2 Inventário } & \mathbf{1 1 7}\end{array}$

6.1.2.1 Características e composição da biomassa 117

$\begin{array}{ll}\text { 6.1.2.2 Processo de gaseificação da biomassa } & 120\end{array}$

6.1.2.3 Limpeza do gás e composição do syngas produzido 121

6.1.3 Análise do Balanço Energético 127

6.1.3.1 Demanda Acumulada de Energia e Tempo de Retorno em Investimento de Energia

6.1.4 Avaliação de Impacto Ambiental

6.2 Sistemas de Energia Fotovoltaica

6.2.1 Objetivo, Escopo e Unidade Funcional 
6.2.2 Inventário

6.2.2.1 Produção mix de silício purificado - silício off grade (OG), grau eletrônico (EG) e grau solar (SG)

6.2.2.2 Silício monocristalino

6.2.2.3 Produção de lâminas

6.2.2.4 Produção de células solares, painéis solares e inversores

6.2.3 Análise do Balanço Energético

6.2.3.1 Demanda Acumulada de Energia e Tempo de Retorno em Investimento de Energia

6.2.5 Avaliação de Impacto Ambiental

\section{CONCLUSÕES E RECOMENDAÇÕES}

7. Interpretação

8 Estudos futuros 
Do ponto de vista de produção, o hidrogênio pode ser obtido por diferentes métodos, tais como eletrólise da água, reforma a vapor, conversão fotoquímica, gaseificação de biomassa e de resíduos, entre outros, todos a partir de fontes renováveis, muitas das quais geograficamente disponíveis em larga escala, como a energia solar e a biomassa oriunda de plantações agrícolas, resíduos agroindustriais e resíduos sólidos municipais. Assim, o entusiasmo mundial de líderes políticos, da comunidade científica e das empresas pelo hidrogênio também se configura em uma promessa de independência energética (HERZOG \&TATSUTANI, 2005).

Contudo, os custos e os benefícios ambientais do hidrogênio dependem da sua fonte de origem e de como é produzido. Isto é, para que o hidrogênio constituase em uma alternativa de energia sustentável, torna-se premente que as repercussões ecológicas, sociais e econômicas, não só do uso final desse vetor, como, e principalmente, da sua fonte e dos processos de produção do mesmo. Destarte, avaliar os potenciais impactos ambientais decorrentes das diferentes rotas de geração do hidrogênio torna-se de suma importância para o uso e pleno desenvolvimento deste vetor energético.

Neste contexto, a metodologia de Avaliação do Ciclo de Vida - ACV, estabelecida pela Organização Internacional para Normalização (International Organization for Standardization), tem se destacado como um instrumento apropriado para fornecer as informações ambientais necessárias de apoio à tomada de decisões relacionadas à sustentabilidade, ao avaliar os impactos ambientais de todas as fases de uma atividade industrial, desde a aquisição de matéria prima até sua disposição final (UTIGKAR \& THIESEN, 2005).

Internacionalmente, diversos pesquisadores têm utilizado a ACV para identificar os riscos e as oportunidades da futura economia do hidrogênio. Observase, por exemplo, a realização de estudos recentes voltados para avaliações comparativas do ciclo de vida ${ }^{1}$ de combustíveis fósseis e de hidrogênio em sistemas de transporte (GRANOVCKII et. al, 2006; ALLY \& PRIOR, 2007). Porém, o mesmo ainda não se constata no Brasil, no qual os estudos sobre a ACV de produtos em geral ou atividade econômica ainda se encontram distantes da realidade internacional (Cf. CALDEIRA-PIRES, 2006).

\footnotetext{
${ }^{1}$ Notadamente voltados para o estágio de uso do ciclo de vida do combustível.
} 
Notadamente após as crises do petróleo na década de 1970, o uso de fontes de energia alternativas aos combustíveis fósseis vem ganhando importância no Brasil e no mundo (CALLE et. al, 2005). Em adição ao declínio das reservas conhecidas e a instabilidade política das regiões com vastos recursos, a questão de como suprir a crescente demanda de energia, sem provocar danos irreparáveis ao meio ambiente, tem sido objeto de intenso debate.

De fato, no decorrer das últimas décadas, o suprimento energético tomou posição central na agenda ambiental global, notadamente dentro das negociações da Convenção do Clima; bem como nas discussões sobre as mudanças de paradigma do desenvolvimento humano. Neste sentido, a relação entre produção e o uso de energia e o desenvolvimento sustentável tem três importantes aspectos (REIS et. al, 2005).

O primeiro refere-se ao reconhecimento do suprimento energético como condição básica para o desenvolvimento econômico, o segundo está relacionado à equidade, no qual, no âmbito energético, pode ser traduzido como universalização do acesso e atendimento das necessidades básicas. O terceiro é a constatação dos significativos impactos que os sistemas energéticos impõem aos sistemas naturais (GOLDEMBERG, 2000).

Desta forma, enquanto o século 20 foi caracterizado pela crescente dependência em combustíveis fósseis, o atual século está sendo direcionado para a transição aos sistemas energéticos alternativos, com o intuito de promover um modelo de desenvolvimento que atenda as necessidades energéticas, compatível com a perspectiva de sustentabilidade.

Neste quadro, muitos pesquisadores tem projetado o hidrogênio como futuro vetor energético, capaz de proporcionar uma alta eficiência de conversão direta em eletricidade, sem os impactos das correspondentes emissões atmosféricas dos combustíveis fósseis (SORENSEN, 2004). A viabilidade de uso a médio prazo do hidrogênio encontra-se na tecnologia de Células a Combustível - $\mathrm{CaC}$, na qual destaca-se, além da eficiência e segurança, a flexibilidade de planejamento (modularidade) e o desempenho ambiental durante o uso. 
Conforme verificado por FUKUROZAKI (2006), também há uma ausência de trabalhos e publicações nacionais sobre o uso da ACV na tecnologia de células a combustíveis $(\mathrm{CaC})$, assim como, dos respectivos sistemas de produção de hidrogênio. Por outro lado, destaca-se que as conclusões obtidas no estudo anterior, permitiram dar um primeiro passo na direção de métodos que visem, dentre outros, minimizar os possíveis impactos associados a esta tecnologia.

Diante das considerações acima, a preocupação primordial do presente trabalho está em convergência com o momento atual. Ou seja, com a necessidade de incorporação de estudos de impactos ambientais, relacionada à tecnologia $\mathrm{CaC}$, ao planejamento de longo prazo no Brasil, como meio de assistir a tomada de decisões e colaborar para o desenvolvimento de sistemas energéticos que vão de encontro as aspirações humanas atuais e futuras. 
Face ao contexto apresentado na introdução, o presente trabalho tem como objetivo geral avaliar o desempenho ambiental e energético de duas potenciais rotas de produção de hidrogênio: sistemas de gaseificação da biomassa e de uma planta de energia solar fotovoltaica. Destarte, os objetivos específicos delimitados para este trabalho foram:

I. Contextualizar a premência do desenvolvimento de sistemas energéticos que atendam aos princípios de sustentabilidade e apresentar a importância do hidrogênio, como vetor energético, bem como suas rotas de produção.

II. Prover informações técnicas, econômicas e ambientais do sistema de conversão energética da biomassa, especificamente a tecnologia de gaseificação de leito fixo e fluidizado e, de energia solar fotovoltaica baseada em silício monocristalino.

III. Avaliar o ciclo de vida dos sistemas energéticos, considerando, como parâmetros de análise, os danos à qualidade do ecossistema, da saúde humana e dos recursos energéticos, bem como a demanda acumulada de energia (CED) e o tempo de retorno de investimento em energia (EPBT).

IV. Por fim, comparar o desempenho ambiental e energético dos sistemas estudados e identificar quais parâmetros favorecem e/ou desfavorecem cada rota analisada em uma futura aplicação na produção de hidrogênio.

Neste sentido, pretende-se prover uma visão integrada e abrangente que subsidie as tomadas de decisões e estratégias, no âmbito da sustentabilidade, para o desenvolvimento de uma "Economia do Hidrogênio" no país. 


\section{FUNDAMENTAÇÃO TÉORICA}

\section{ENERGIA E SUSTENTABILIDADE}

\section{$1.1 \quad$ Sistemas de Energia}

As conquistas das civilizações têm sido alcançadas por meio da crescente eficiência e transformação das várias formas de energia. Ou seja, a energia é indispensável para o contínuo desenvolvimento humano e crescimento econômico (REIS et. al. 2005). Sob a perspectiva da sociedade, o sistema de energia é projetado para atender as suas demandas por meio de uma variedade de serviços, tais como iluminação, climatização, refrigeração, transporte, informação, produção de bens de consumo e serviços, entre outros. Em outras palavras, o objetivo do sistema energético é propiciar aos consumidores os benefícios que a energia oferece.

Segundo Jochen (2000), a cadeia produtiva de energia que propicia estes serviços inicia-se com a extração ou coleta de energia primária, na qual em um ou mais estágios, pode ser convertida em vetores energéticos, tais como a eletricidade ou o hidrogênio, que permitem o uso final da energia. Os equipamentos de uso final, como por exemplo, lâmpadas, motores, máquinas, convertem os vetores em energia útil. Um exemplo da cadeia energética é apresentado na figura 1.1.

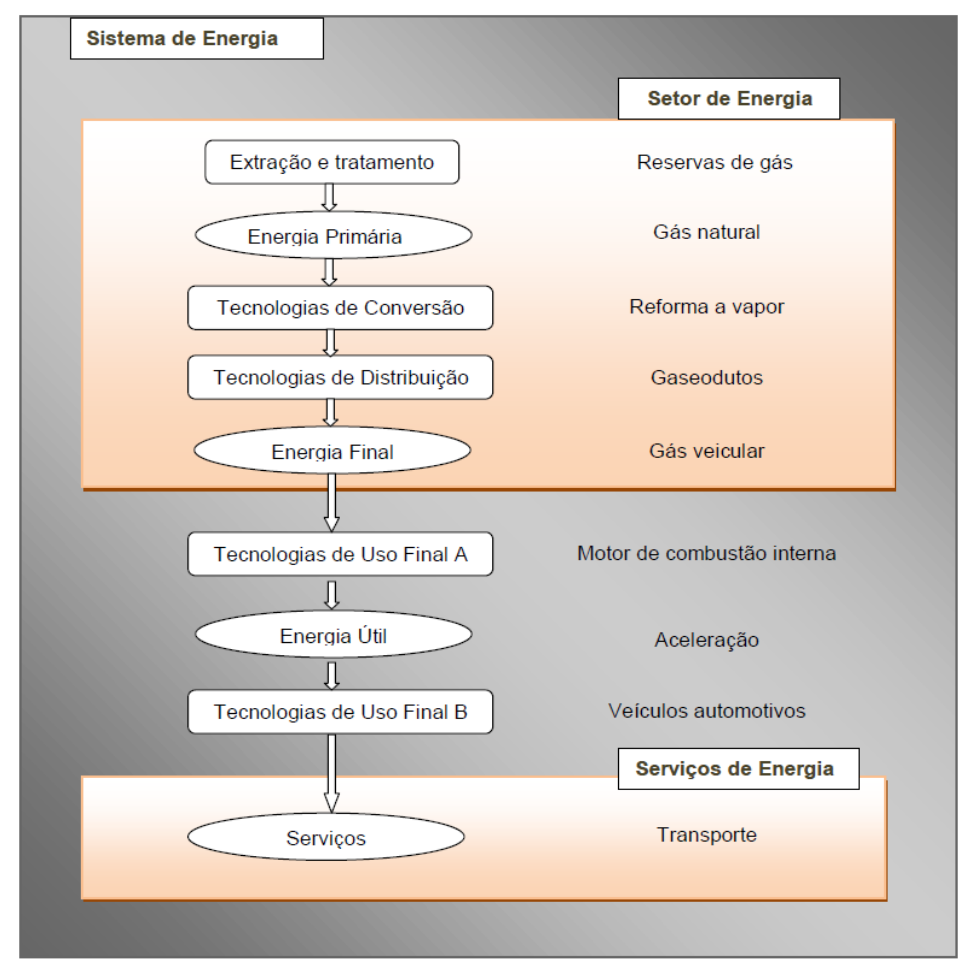

Figura 1.1 - Cadeia de produção de energia a partir da extração - topo - até os serviços - base (baseado em JOCHEN, 2000). 
Os sistemas de energia resultam da combinação de várias tecnologias, infraestrutura (capital), trabalho (conhecimento), materiais e vetores energéticos. Do ponto de vista do consumidor, o vetor energético ou a fonte deste vetor possui menor significância. Isto é, geralmente, os consumidores ignoram o topo da cadeia do sistema de energia, uma vez que esta é conduzida da base (serviços) para o topo, onde os fluxos de energia são direcionados em função da disponibilidade dos recursos energéticos e os seus processos de conversão.

De fato, Rogner \& Popescu (2000) apontam que para os consumidores, os fatores importantes são os valores econômicos ou a utilidade derivada dos serviços da cadeia produtiva de energia. No entanto, recursos, reservas energéticas e sua ocorrência, bem como as forças condutoras - oferta e demanda de energia, capital, conhecimento e tecnologia - estão intimamente relacionadas.

Se por um lado, os sistemas de energia modernos baseiam-se em combustíveis processados ou manufaturados e em sofisticados equipamentos de conversão, por outro, os sistemas tradicionais, usualmente, apresentam combustíveis não processados, próximos à sua forma primária e dispositivos tecnológicos rudimentares (ou nenhuma tecnologia). Comumente, tecnologias rudimentares de conversão de energia, comumente, implicam em baixas eficiências e elevado índice de poluição.

Notoriamente, nenhuma produção de energia ou tecnologia de conversão é realizada sem riscos ou resíduos. Em algum ponto de toda a cadeia energética, desde a extração de recursos até a provisão de serviços de energia - poluentes são produzidos, emitidos ou dispostos (HOLDREN\& SMITH, 2000). Enquanto a queima de combustíveis fósseis é responsável por grande parte da poluição do ar nas cidades, a manufatura de painéis solares produz resíduos tóxicos e, em alguns países em desenvolvimento, o uso de biomassa contribui para a desertificação.

É neste sentido que a energia foi reconhecida como uma questão chave para atingir um desenvolvimento sustentável (UNEP, 2000; REIS \& SILVEIRA, 2001, GRIMONI \& UDAETA, 2004; REIS et. al , 2005; FUKUROZAKI, 2006), no qual a acessibilidade e a provisão adequada são essenciais para erradicar a pobreza, aperfeiçoar o bem estar social e promover o crescimento econômico. 


\section{FUNDAMENTAÇÃO TÉORICA}

Tendo em vista, a crescente tendência da sociedade em demandar serviços de energia associados a uma maior proteção ao meio ambiente e à saúde humana, a exploração de recursos energéticos, a orientação tecnológica e as mudanças institucionais direcionam-se atualmente para o desenvolvimento de sistemas de energia sustentáveis.

\subsection{Desenvolvimento de Sistemas de Energia Sustentável}

O termo Energia Sustentável não se refere apenas a simples continuidade do suprimento, mas à produção e uso de recursos energéticos de forma a promover ou no mínimo ser compatíveis - a longo prazo com o bem estar da sociedade e o equilíbrio natural (UNEP, 2000). Ou seja, a energia deve ser produzida e utilizada de forma a suportar o desenvolvimento humano em todas as suas dimensões sociais, econômicas e ambientais.

Segundo Reis e colaboradores (2005), a atual matriz energética mundial depende, ainda, significativamente (mais de $80 \%$ ) de recursos energéticos não renováveis, tais como petróleo e derivados, gás natural e carvão, cuja produção e uso contribuem para aumentar a concentração dos gases do efeito estufa (GEE). O Brasil, em particular, é um dos poucos países no qual a participação de fontes renováveis (hidroelétrica e biomassa) na matriz energética é expressiva, cerca de 45\%(Figura 1.2).

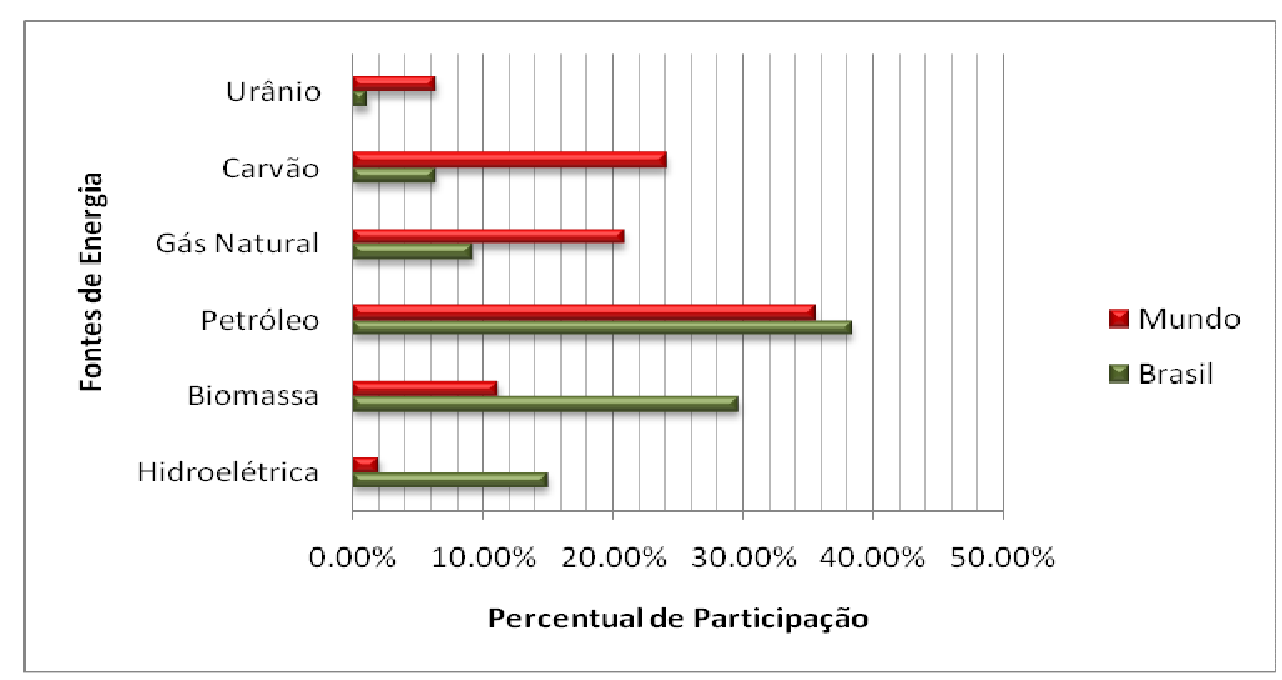

Figura 1.2 - Participação das fontes de energia na matriz energética mundial e no Brasil (modificado a partir do Balanço Energético Nacional - Ministério de Minas e Energia, 2006). 


\section{FUNDAMENTAÇÃO TÉORICA}

Neste quadro, os sistemas de energia existentes, na maioria dos países, são ainda conflitantes com o objetivo do Desenvolvimento Sustentável (UNITED NATIONS DEVELOPMENT PROGRAMME - UNDP, 1997). Dentre as relações entre energia e as variáveis socioeconômicas e ambientais destacam-se:

- Os modernos sistemas de fornecimento de energia, incluindo combustíveis líquidos e gasosos, eletricidade e tecnologias de uso final mais eficientes não estão disponíveis para cerca de 2 bilhões de pessoas (UNEP, 2000). Isto, por sua vez, limita as oportunidades de crescimento econômico mundial e melhoria dos padrões de qualidade de vida.

- A disparidade no acesso a energia comercial e de serviços de energia são incoerentes com o conceito de desenvolvimento humano e a estabilidade social. Particularmente, mulheres e crianças são desproporcionalmente afetadas pela dependência de combustíveis tradicionais, observados em muitos países em desenvolvimento.

- A saúde da população é ameaçada pelo elevado índice de poluição resultante do uso da energia no âmbito doméstico, na escala local e regional. Os impactos ambientais das emissões relacionadas aos sistemas de energia incluindo partículas finas e precursores da deposição ácida - contribuem significativamente para a poluição do ar e a degradação ecológica.

- A influência das emissões dos gases do efeito estufa resultantes das atividades antropogênicas, a maioria derivada da produção e uso da energia, é reconhecida cientificamente nas mudanças climáticas globais.

- O fornecimento adequado é economicamente inacessível para a maioria da população mundial. Soma-se ainda a dependência de combustíveis fósseis, cuja importação conduz a vulnerabilidade econômica de muitos países, em virtude das interrupções no fornecimento.

Portanto, encontrar caminhos para expandir os sistemas de energia, simultaneamente a mitigação dos impactos ambientais associados, representa um desafio crítico para humanidade. Na dimensão social, a energia está particularmente relacionada à diminuição da pobreza, ao crescimento econômico, à urbanização e a falta de oportunidades para as mulheres. Embora estas questões afetem a demanda 


\section{FUNDAMENTAÇÃO TÉORICA}

de energia, tal relação é uma via de mão dupla: a qualidade e quantidade de serviços de energia e como estes são alcançados tem, igualmente, suas conseqüências nas variáveis da dimensão social.

\subsubsection{Energia e a Dimensão Social}

Cerca de 1,3 bilhões de pessoas em países em desenvolvimento vivem com menos de 1 \$ por dia (REDDY et. al, 2000). Porém, somente a medição da renda não retrata a miséria e a ausência de opções que a pobreza representa. Os padrões de consumo de energia das classes menos favorecidas - especialmente nas áreas rurais e àquelas baseadas nos combustíveis tradicionais - tendem a manter a população empobrecida.

$\mathrm{Na}$ escala mundial, 2 bilhões de pessoas estão sem acesso à eletricidade e, em igual número, continuam usando tradicionais combustíveis sólidos para cozinhar e aquecer (UNEP, 2000). Centenas de milhões de pessoas, a maioria mulheres e crianças, consomem horas por dia na coleta de água e madeira para consumo próprio, geralmente, a consideráveis distâncias. Em razão destas demandas, mulheres e crianças, comumente, não possuem oportunidades para educação e outras atividades produtivas.

Rendas limitadas tendem a forçar a população a utilizar combustíveis tradicionais e ineficientes tecnologias. Na população de baixa renda, a madeira para a queima é o combustível dominante, enquanto nas de rendas elevadas, este recurso é substituído pela eletricidade. A falta de eletricidade, usualmente, representa iluminações inadequadas e poucos eletrodomésticos, bem como limitação das possibilidades de comunicação e entretenimento. $O$ acesso a vetores energéticos habilita a comunidade, em curto prazo, a obter melhorias nos padrões de qualidade de vida. Destarte, a disponibilidade de energia adequada e acessível pode permitir a quebra do ciclo de pobreza.

Outra questão social relacionada à energia é a crescente concentração da densidade demográfica nos centros urbanos. Embora o mercado, em geral, direcione a urbanização, a criação de mais opções para os residentes rurais, por meio de intervenções energéticas, pode reduzir potencialmente as migrações e o crescimento das cidades. 
FUNDAMENTAÇÃO TÉORICA

\section{FUNDAMENTAÇÃO TÉORICA}

Ainda que as externalidades negativas associadas ao uso da energia em áreas urbanas possam ser severas, várias estratégias podem mitigar os efeitos e promover a conservação da energia. Por exemplo, considerar a variável energética no planejamento do uso do solo, no projeto físico de infraestrutura, padrões de construção e sistema de transporte pode reduzir o aumento da demanda da energia e consequentes efeitos ambientais que acompanham a rápida urbanização.

\subsubsection{Energia e a Dimensão Ambiental}

Independente da escala, os atuais padrões de geração e uso de energia são responsáveis por consideráveis impactos à saúde humana e ao meio ambiente (REIS \& SILVEIRA, 2001 GRIMONI \& UDAETA, 2004; FUKUROZAKI, 2006). No âmbito doméstico, cerca de metade da população utiliza combustíveis sólidos, tais como a biomassa e o carvão, para o aquecimento e cozimento em simples equipamentos, que produzem grande quantidade de emissões poluentes.

Tal poluição é responsável, provavelmente, por 4 a $5 \%$ dos problemas globais relacionadas à saúde humana (HOLDREN \& SMITH, 2000). A exposição a uma baixa qualidade do ar (resultante, por exemplo, da queima dos combustíveis em espaços pouco ventilados) é associada a um aumento de doenças respiratórias e mortes prematuras. Os principais impactos no ecossistema, relacionados ao uso de combustíveis sólidos são, respectivamente, as atividades de mineração e utilização do carvão e a extração de madeira.

No âmbito industrial, os ciclos de combustíveis resultaram em significativos riscos à saúde dos trabalhadores e a comunidade de entorno de plantas de energia. Por outro lado, a principal causa da poluição do ar nas áreas urbanas, principalmente de cidades densamente povoadas, origina-se da queima de combustíveis fósseis e fontes estacionárias. Basicamente, os poluentes emitidos são óxidos de enxofre e nitrogênio, monóxido de carbono e material particulado suspenso, onde os setores de transporte e de geração de energia são os principais contribuintes.

$\mathrm{Na}$ escala regional, precursores da deposição ácida, também resultantes da queima, são precipitados a quilômetros de distância do local de origem comumente atravessando os limites de fronteiras nacionais (FUKUROZAKI, 2006). O resultado da acidificação caracteriza-se por danos aos sistemas naturais, 


\section{FUNDAMENTAÇÃO TÉORICA}

plantações e construções urbanas e, ao longo do tempo, a alterações da composição e funcionamento de um ecossistema inteiro. Em muitas regiões no mundo, a acidificação tem reduzido à produtividade pesqueira e de propriedades agrícolas (SEGUIN, 2007).

Reconhecidamente, a queima de combustíveis fósseis produz mais dióxido de carbono do que qualquer outra atividade humana e, é a maior fonte antropogênica de emissões de GEE. Na escala global, os sistemas de energia são responsáveis por 2/3 do aumento destas emissões. Segundo o Intergovernamental Panel on Climate Change - IPCC (IPCC, 2001), as projeções científicas (baseadas no aumento dos GEE) das alterações da composição da atmosfera, incluindo o padrão de chuvas, indicam a nítida influência das atividades humanas nas mudanças climáticas.

Segundo Cohen (2003), o uso de energia tem sido objeto de grandes discussões no tocante ao seu papel no desenvolvimento dos países. Algumas correntes econômicas afirmam que o desenvolvimento econômico e consumo de energia caminham necessariamente juntos. Desta forma, entre outros impactos pertinentes ao sistema de energia que requerem especial atenção, destacam-se àqueles relacionados às questões econômicas.

\subsubsection{Energia e a Dimensão Econômica}

Serviços específicos de energia são fornecidos pelas várias combinações entre fontes de energia e tecnologia. Neste sentido, tecnologia é frequentemente vista como conhecimento e capital. Para uma ampliação dos serviços de energia, os recursos energéticos e a tecnologia dominante, podem ser substituídos por capital e conhecimento. Isto é, substituir tecnologias menos eficientes e poluidoras, por outras mais eficientes e mais limpas, significa a substituição de capital ${ }^{1}$ e conhecimento por energia. Ou seja, tecnologia é uma variável determinante entre o suprimento e acesso aos serviços de energia, viabilidade de crescimento econômico e compatibilidade ambiental.

\footnotetext{
${ }^{1}$ Investimento de capital envolve tipicamente a energia incorporada em materiais, manufatura, construção, bem como mão de obra e conhecimento.
} 
FUNDAMENTAÇÃO TÉORICA

\section{FUNDAMENTAÇÃO TÉORICA}

No entanto, tecnologia é mais do que uma planta de geração de energia, um automóvel ou refrigerador; esta inclui infraestrutura (construções), padrões de assentamento, estradas, sistemas de transporte, plantas industriais e equipamentos. Não obstante, também compreende preferências sociais e culturais, bem como leis e regulamentações que refletem a compatibilidade das opções tecnológicas com tais preferências (ROGNER \& POPESCU, 2000).

Neste panorama, a disponibilidade de energia a qualquer tempo, em várias formas, em quantidades suficientes e a preços acessíveis são pontos críticos no debate sobre Energia e Desenvolvimento Sustentável. Isto é, o suprimento energético é foco de atenção devido, tanto a distribuição irregular das reservas de petróleo (no qual a maioria dos países depende), quanto à capacidade de desenvolver tecnologias e explorar recursos renováveis.

Embora os recursos renováveis sejam melhores distribuídos do que os fósseis e nucleares, seu potencial econômico é afetado por restrições no uso do solo, variação da disponibilidade da irradiação solar na superfície terrestre (em função da latitude), localização (vento e hidroeletricidade) e qualidade do solo e água (biomassa). Ainda assim, os fluxos de energia renovável são, na ordem de magnitude, 3 (três) vezes maior do que a demanda global (ROGNER \& POPESCU, 2000).

Sob o ponto de vista dos recursos, mesmo diante da ausência de limitações reais no futuro da disponibilidade energética, a existência de fontes renováveis é menos relevante do que como estas podem contribuir no suprimento dos serviços de energia. Por outro lado, à medida que a sociedade reconhece a insustentabilidade dos atuais sistemas energéticos e a necessidade premente de introduzir adequadas políticas públicas, a participação de serviços que utilizam recursos renováveis pode alterar a forma como é realizado o suprimento energético.

De outra forma, políticas públicas podem estimular os avanços e o desenvolvimento tecnológico, estimular o consumo eficiente de recursos, os processos de conversão limpos e uso de fontes renováveis. No campo tecnológico, destaca-se, além do aumento da eficiência de conversão e a conservação da energia, o uso de novos vetores energéticos, particularmente o hidrogênio. Este 
FUNDAMENTAÇÃO TÉORICA

\section{FUNDAMENTAÇÃO TÉORICA}

vetor tem sido vislumbrado como o combustível do futuro, no qual credita-se diversos benefícios sociais, econômicos e ambientais (BALLAT, 2008).

O potencial a longo prazo do hidrogênio é o de, entre outros, permitir a redução da dependência de combustíveis fósseis e das emissões de carbono no setor de transporte. No âmbito da energia sustentável, a introdução de sistemas de energia baseados em hidrogênio é uma das numerosas estratégias "ganha-ganha" que pode, simultaneamente, beneficiar o bem estar social, o meio ambiente (em diferentes escalas) e a economia (SORENSEN, 2005). 


\section{HIDROGÊNIO}

\subsection{Panorama Geral}

O documento Estado da Arte e Tendências das Tecnologias para Energia, elaborado pelo Centro de Gestão e Estudos Estratégicos - CGEE (2003) relata que o uso do hidrogênio como vetor energético tem sido crescentemente estudado e existe já um razoável consenso sobre suas vantagens em sistemas de energia futuros. Revisões a esse respeito pode ser encontradas nas publicações de Kordesh \& Simader (1996), Soresen (2004, 2005), Ballat (2008), Babir (2008) e Bartels (2010).

Atualmente, o uso ideal do hidrogênio para produção de energia elétrica ocorre por meio da Célula a Combustível $(\mathrm{CaC})$. Estas são dispositivos eletroquímicos que podem converter continuamente a energia química desse elemento em eletricidade, sem a necessidade de combustão a quente e com um rendimento global superior aos equipamentos de transformação convencionais.

Em adição a natureza eletroquímica da reação produzindo água (KORDESH \& SHIMADER, 1996), a alta eficiência pode propiciar uma significativa redução do uso de combustíveis fósseis e da liberação de gases do efeito estufa, resultando em emissões locais extremamente baixas durante o uso, fator especialmente importante em áreas densamente povoadas (PENHT, 2004).

Desta forma, os diferentes tipos de tecnologia $\mathrm{CaC}$ podem viabilizar a utilização energética do hidrogênio, em aplicações móveis e estacionárias, incluindo pequenas residências, plantas de energia e calor de média e larga escala, respectivamente. No setor móvel, as $\mathrm{CaC}$, particularmente as de baixa temperatura de operação (80 a $90{ }^{\circ} \mathrm{C}$ ), como a Célula a Combustível de Membrana Trocadora de Prótons - PEMFC, podem ser usadas em veículos comerciais e coletivos, trens, aviões, barcos, além de sistemas portáteis de diversos usos (BAUEN et. al., 2003).

Diante deste quadro, os líderes políticos, a comunidade científica, a mídia e as grandes empresas automobilísticas têm abraçado o hidrogênio como a melhor opção para responder rapidamente as ameaças levantadas pelo aquecimento global e a dependência da importação de combustíveis fósseis. $O$ entusiasmo pelo hidrogênio é largamente predizível, não somente, pelas potenciais vantagens em 
relação ao petróleo como combustível veicular, como também pela grande diversidade de fontes de suprimento, na qual a biomassa e energia solar representa um importante papel na promessa de independência energética, por ser encontrar distribuída mundialmente e, amplamente, em países tropicais como o Brasil.

Neste sentido, além das propriedades, aplicações atuais e fabricação industrial do hidrogênio, este capítulo apresenta as rotas de produção energética do hidrogênio, notadamente a partir da biomassa e da energia solar fotovoltaica, bem como de outras tecnologias vigentes e aplicáveis.

\subsection{Propriedades e Aplicações do Hidrogênio}

O hidrogênio é o mais simples e abundante elemento químico conhecido no universo. Sob condições de pressão e temperatura ambiente, caracteriza-se por ser um gás incolor, inodoro, insípido e mais leve que os demais gases, podendo se dispersar facilmente na atmosfera. Sua fórmula molecular é $\mathrm{H}_{2}$ e o principal isótopo, consiste de um próton e um elétron ocupando o menor ângulo no estado de valência zero, relativa à energia de $2,18 \times 10^{-18} \mathrm{~J}$ (Tabela 3.1).

Tabela 2.1 - Propriedades do Hidrogênio (SORESEN, 2005, modificado).

\begin{tabular}{cc} 
NÚMERO ATÔMICO & $\mathbf{1}$ \\
\hline ESTADO DE VALÊNCIA ZERO & $2,18 \mathrm{aJ}$ \\
MASSA MOLAR & $2,016103 \mathrm{~kg} \mathrm{~mol}^{-1}$ \\
\hline ENERGIA DE DISSOCIAÇÄO ( $\mathrm{H}_{2}$ PARA 2H) & $0,71 \mathrm{aJ}$ \\
\hline CONDUTIVIDADE IÔNICA DOS ÍONS H+ (DILUÍDOS EM ÁGUA EM 298K) & $0,035 \mathrm{~m}^{2} \mathrm{~mol}^{-1} \mathrm{\Omega}^{-1}$ \\
\hline PONTO DE FUSÄO ( EM 101,33 kPa) & $13,8 \mathrm{~K}$ \\
\hline PONTO DE EBULIÇÃO (EM 101,33kPa) & $20,3 \mathrm{~K}^{-1}$ \\
\hline CAPACIDADE DE AQUECIMENTO ( EM PRESSAO CONSTANTE E 298K) & $14,3 \mathrm{~kJ} \mathrm{~K}^{-1} \mathrm{~kg}^{-1}$ \\
\hline SOLUBILIDADE EM ÁGUA (A 101,33 kPa E 298 K) & $0,019 \mathrm{~m}^{-3} \mathrm{~m}^{-3}$ \\
\hline DENSIDADE, H2 ( EM 101,33 kPa E 298 K) & $0,084 \mathrm{~kg} \mathrm{~m}^{-3}$ \\
\hline
\end{tabular}

Apesar da pequena massa específica, o hidrogênio apresenta alto poder calorífico, não é tóxico e é bastante reativo. Devido à baixa densidade volumétrica, o hidrogênio pode ser armazenado e transportado como gás comprimido $\left(\mathrm{CGH}_{2}\right)$ ou em estado liquefeito $\left(\mathrm{LH}_{2}\right)$, no entanto, o ponto de ebulição torna a liquefação um processo de uso intensivo de energia.

Comumente, o hidrogênio apresenta-se associado a outros elementos químicos. É encontrado como gás interestelar e como o principal constituinte da 
formação de estrelas. Na Terra, o hidrogênio encontra-se como parte das moléculas de água, metano e material orgânico, fossilizados ou não.

Embora o hidrogênio não ocorra naturalmente em grandes proporções, também pode ser formado por processos naturais, como resultado da atividade metabólica das bactérias na decomposição de remanescentes vegetais e animais no solo, onde tende a se acumular somente em profundidade. Pesquisas atuais sugerem que os estoques subterrâneos de hidrogênio podem ser muito mais extensos do que os previamente identificados, porém os aspectos econômicos e ambientais tornam essas reservas naturais não atrativas (HERZOG \& TATSUTANI, 2005).

Não obstante, esse elemento pode e vem sendo produzido a partir de fontes primárias de energia, disponíveis livremente na natureza, tanto renováveis, as que natural e/ou continuamente renovam a si mesmas (água e biomassa), quanto as não renováveis, como os combustíveis fósseis (carvão, gás natural e petróleo), todos largamente compostos de átomos de carbono e hidrogênio em diferentes combinações.

Presentemente, o hidrogênio é produzido por diferentes processos para fins não energéticos, sendo o principal insumo para a síntese de amônia e metanol, tratamento de óleos e graxas e para a indústria de vidro e eletrônicos, entre outros. Estima-se que, em 2000, a produção e consumo mundial de hidrogênio foi cerca de 500 bilhões de $\mathrm{Nm}^{3}$ - metros cúbicos normais, em grande parte utilizada em refinarias de óleo e na manufatura de fertilizantes e produtos químicos (SPATH \& DAYTON, 2003).

\subsection{Produção Industrial de Hidrogênio}

A produção de hidrogênio é comercialmente empregada na produção de amônia, metanol e na indústria de refino do petróleo, na qual as tecnologias de reforma a vapor e purificação são usadas para converter hidrocarbonetos leves, o gás natural, o gás liquefeito de petróleo/butano e naftas leves em hidrogênio. Os hidrocarbonetos pesados, como o óleo combustível, podem ser usados para a 
produção de hidrogênio por oxidação parcial (BAIN, OVEREND \& CRAIG, 2005), tal como a tecnologia oferecida pela Texaco (Figura 2.1).

Por várias décadas, a reforma a vapor de hidrocarbonetos tem sido o processo mais eficiente, econômico e largamente utilizado na produção de hidrogênio (KORDESH \& SHIMADER, 1996). A tecnologia dominante é a reforma a vapor do metano, oriundo do gás natural, cuja conversão catalítica produz hidrogênio e óxidos de carbono. Tipicamente, dividi-se em quatro etapas seqüenciais: pré-tratamento (dessulfurização), reforma a vapor, conversão shift água-gás e purificação do hidrogênio. $O$ metano reage com o vapor sob pressão de 3 a 25 bar na presença de um catalisador para produzir hidrogênio, monóxido de carbono e pequenas quantidades de dióxido de carbono.

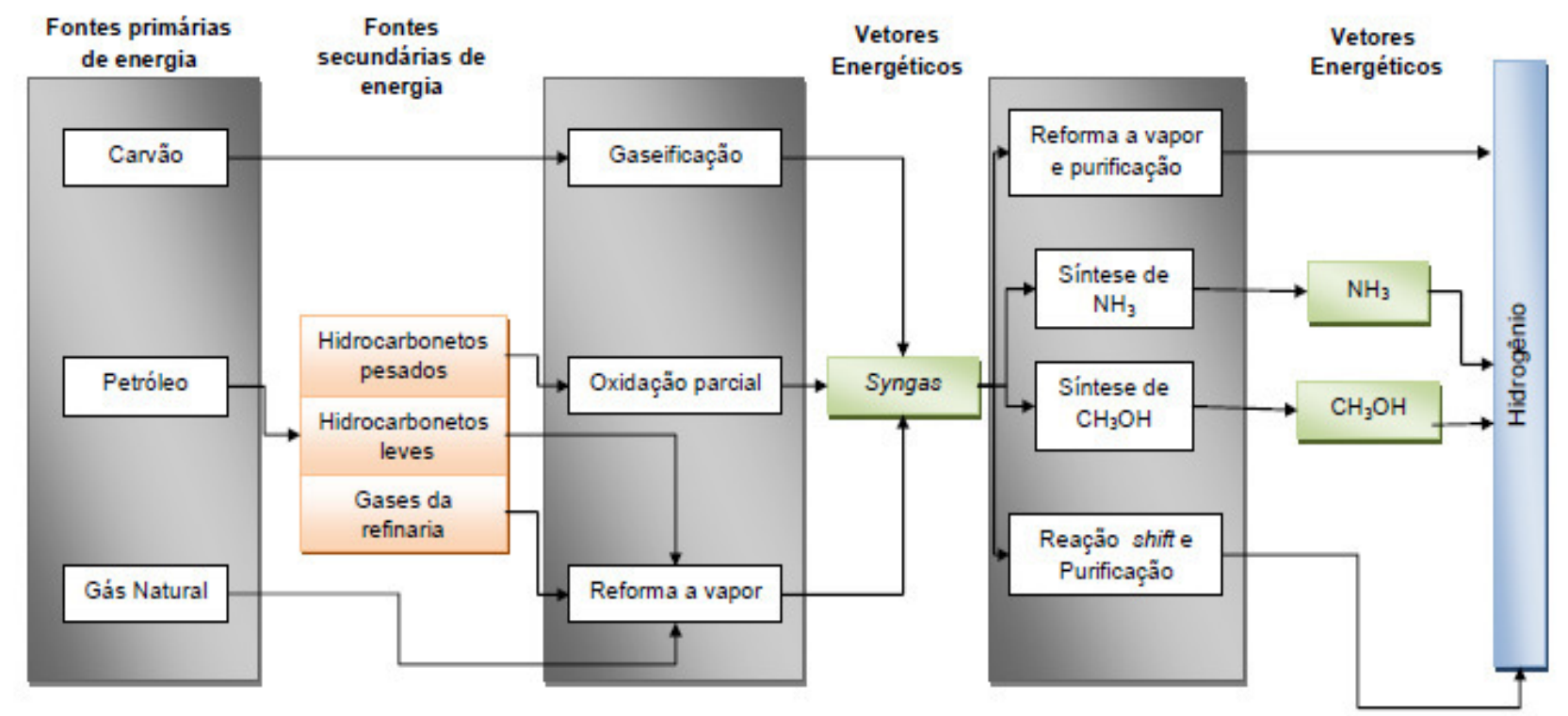

Figura 2.1 - Diagrama básico das rotas convencionais de produção de hidrogênio (FUKUROZAKI, 2011)

Na etapa de conversão, denominada reação shift água-gás, o monóxido de carbono e o vapor de água reagem para produzir dióxido de carbono e mais hidrogênio. No estágio final, conhecido como Pressure Swing Adsorption - PSA, o dióxido de carbono e outras impurezas são removidos do gás, propiciando a obtenção de hidrogênio puro.

Nos casos, onde o gás natural não se encontra viável economicamente, ou há excesso de óleos pesados disponíveis a baixo custo, a tecnologia utilizada para a 
produção de hidrogênio é a oxidação parcial de hidrocarbonetos líquidos (KORDESH \& SIMADER, 1996). Esse processo ocorre sob condições limitadas de quantidades de oxigênio (tipicamente 0 ar), que não são suficientes para oxidá-los em dióxido de carbono e água.

$\mathrm{Na}$ oxidação parcial, a menor quantidade estequiométrica de oxigênio disponível para a reação, resulta em produtos, primariamente, hidrogênio e monóxido de carbono, além de pequenas quantidades de dióxido de carbono e outros componentes. O gás produzido é comumente referenciando como gás de síntese ou syngas, do qual o hidrogênio pode ser produzido. Para maximizar a geração de hidrogênio adicional, usualmente submete-se o syngas à reação shift água-gás, tal como na reforma.

Haussinger et. al. (2000) apud Spath \& Dayton (2003), apontam que $77 \%$ da produção mundial de hidrogênio origina-se a partir de petroquímicos, $18 \%$ do carvão, $4 \%$ da eletrólise da água e $1 \%$ de outras fontes. O processo térmico utilizado para converter o carvão em uma mistura gasosa de hidrogênio, monóxido de carbono, dióxido de carbono e outros componentes, pela aplicação de calor sob pressão e na presença de vapor é a gaseificação.

Kordesh \& Simader (1996) relatam que a gaseificação do carvão tem sido objeto de consideráveis pesquisas e esforços de desenvolvimento comercial para a geração de eletricidade em plantas de ciclo combinado, para a produção de reservas de monóxido de carbono e hidrogênio, bem como na fabricação de gás natural sintético. Na escala comercial, plantas de gaseificação de carvão (1000 t/dia) para essas aplicações estão atualmente em operação.

Outra forma de produção bem conhecida e que vem sendo utilizado para a produção industrial desde meados de 1900 (SOLLI, 2004) é a eletrólise. Neste processo, a água é convertida em hidrogênio e oxigênio pela aplicação e passagem de uma corrente direta na água, contendo sais de hidróxido de metais alcalinos. Tipicamente, apresenta uma planta de purificação, eletrolisador, separação do gás, transformador, regulador e retificadores. 
Embora esta tecnologia apresente um alto custo, comparado à reforma a vapor ou quando a eletricidade é obtida de combustíveis fósseis, a alta pureza do hidrogênio necessária em algumas aplicações é facilmente obtida (SORESEN, 2004). Tal aspecto somado à flexibilidade de operação justifica, em termos gerais, sua participação no mercado atual.

Conforme o Ministério de Minas e Energia - MME (MCT, 2007), no Brasil, a quantidade de hidrogênio de uso industrial é bastante expressiva nas indústrias de petróleo, alimentícia, de fertilizantes e de aço. Em 2002, foram produzidas 425 mil toneladas de hidrogênio no Brasil. Em 2004, a produção cresceu, sendo que apenas a Petrobrás ultrapassou 180 mil toneladas/ano de hidrogênio produzido nas refinarias de petróleo. Essa quantidade, se convertida integralmente em eletricidade por meio de células a combustível de $40 \%$ de eficiência, geraria mais de 2,4 TWh.

Contudo, a produção de hidrogênio para fins energéticos é praticamente inexistente no Brasil. Estima-se que esteja em $5.000 \mathrm{~m}^{3} / \mathrm{ano}$, consumida totalmente nos projetos de demonstração. Os sistemas de eletrólise atuais não são competitivos e a reforma de gás natural só é viável economicamente em grande escala, adequada aos sistemas de geração muitos $\mathrm{MW}$, mas não às plantas baseadas em células a combustível existentes hoje, abaixo de 400 kW (MME, 2005).

Por outro lado, o hidrogênio obtido a partir da eletrólise via energia solar fotovoltaica e sistemas de gaseificação da biomassa sinalizam rotas alternativas e promissoras de produção energética de hidrogênio.

\subsection{Rotas de Produção Energética}

De acordo com Herzog \&Tatsutani (2005), cenários a longo prazo para a completa e sustentável economia do hidrogênio, com baixa ou nenhuma emissão para o aquecimento global, indica que o hidrogênio poderá ser produzido usando a eletricidade gerada por recursos renováveis (como a energia solar e eólica), de outros hidrocarbonetos ${ }^{1}$, usando processos que capturam e estocam as emissões de dióxido de carbono, e principalmente da biomassa, usando uma variedade de processos termoquímicos e bioquímicos potencialmente promissores (figura 2.2).

\footnotetext{
${ }^{1}$ Neste caso oriundo de fontes renováveis, como por exemplo, a biomassa.
} 
Particularmente em relação à biomassa, o Laboratório Nacional de Energia Renovável (National Renewable Energy Laboratories - NREL) tem desenvolvido métodos para a conversão desse recurso em combustíveis, produtos químicos, calor e energia. $\mathrm{O}$ crescente sucesso dos esforços em pesquisa indica que a biomassa é atualmente uma das melhores opções para a produção de hidrogênio renovável (NREL, 2003).

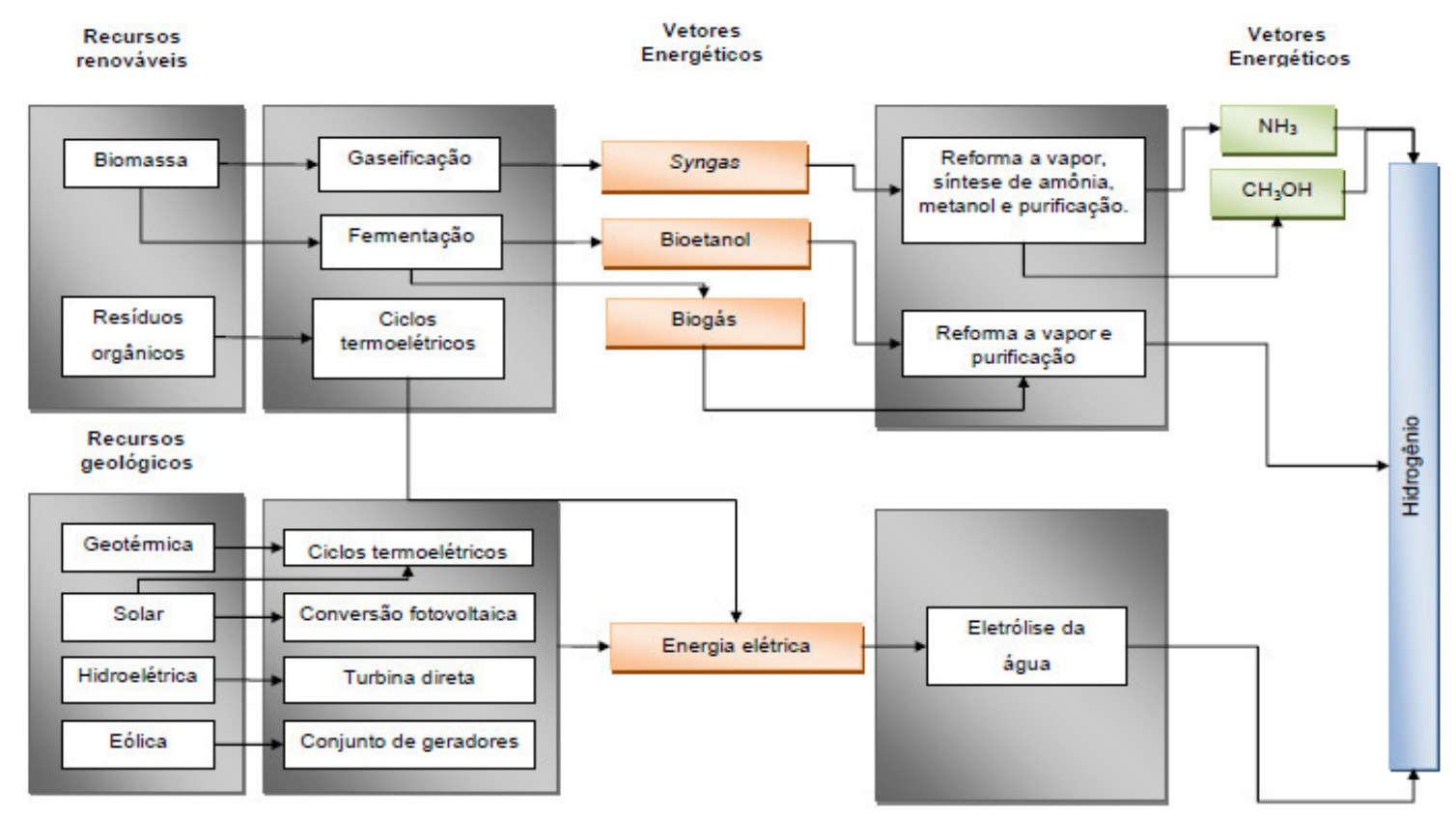

Figura 2.2 - Diagrama básico das rotas alternativas de produção de hidrogênio (FUKUROZAKI, 2011)

Para Walter e colaboradores (2005), muitos fatores têm contribuído de forma combinada para o crescente interesse na biomassa como fonte de energia, entre eles encontram-se as questões ambientais associadas ao aquecimento global, o crescente aumento dos preços de petróleo e da demanda de eletricidade, as mudanças no setor elétrico e a disponibilidade de matéria prima, principalmente resultante da indústria da cana de açúcar e de papel e celulose (particularmente no que se refere às fontes no Brasil).

Tais fatores, em conjunto com os novos desenvolvimentos tecnológicos, aumentaram significativamente a abrangência do uso da biomassa na geração de energia, em especial no que se refere à produção de vetores energéticos. Dentre os métodos de produção de hidrogênio baseada em biomassa destacam-se: i) pirólise, 


\section{FUNDAMENTAÇÃO TÉORICA}

ii) gaseificação conhecida como supercritical water conditions gasification - SWCG e, iii) gaseificação convencional - leito fixo e leito fluidizado.

Em linhas gerais, a gaseificação é a conversão em altas temperaturas de combustíveis sólidos carbonáceos em uma mistura de gases, algumas vezes também reconhecida como syngas, consistindo em $\mathrm{CO}, \mathrm{H}_{2}, \mathrm{CO}_{2}$, metano $\left(\mathrm{CH}_{4}\right)$, metano e nitrogênio $\left(\mathrm{N}_{2}\right)$ e pequenas quantidades de hidrocarbonetos pesados. Não somente o syngas pode ser usado para a geração de calor e energia, como também servir como fonte para a produção de combustíveis líquidos e produtos químicos. (Figura 2.3).

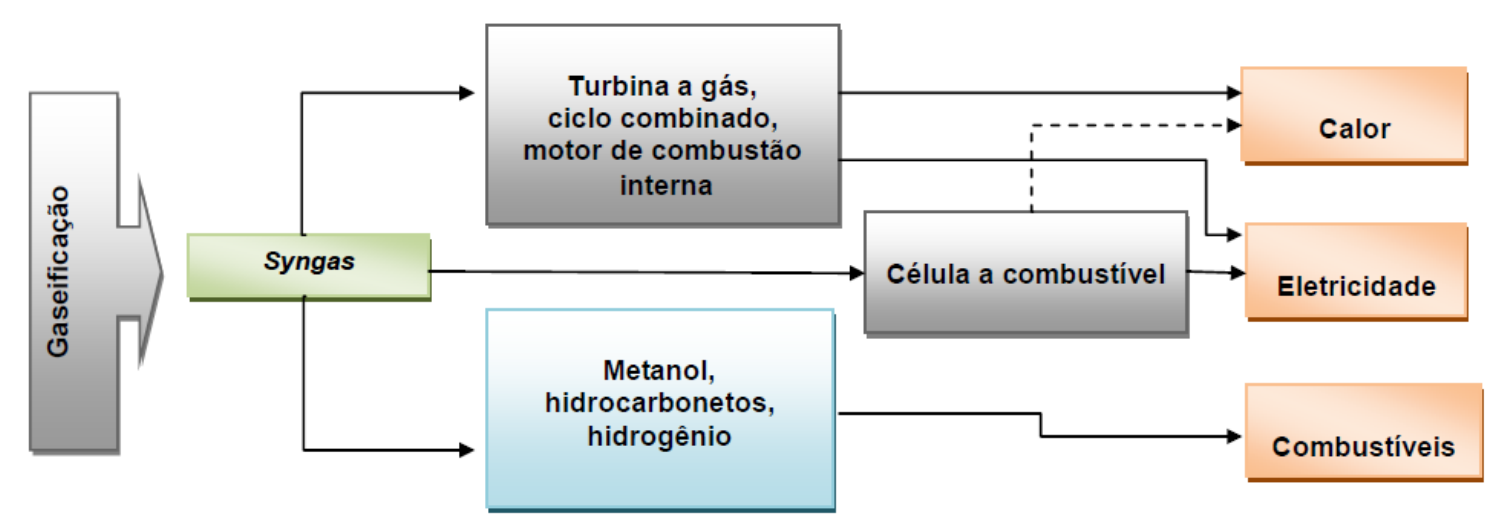

Figura 2.3 - Gaseificação da biomassa e produção de combustíveis, eletricidade e calor (FUKUROZAKI, 2011).

O syngas como produto intermediário da gaseificação, tem dois aspectos atrativos: i) uma grande variedade de reservas de biomassa que podem ser completamente convertidas, e ii) o syngas é um produto intermediário universal para uma produção diversos combustíveis de transporte (Fischer-Tropsch diesel, gasolina, nafta, querosene, metanol, etanol, dimetil éter, hidrogênio, dentre outros) (Figura 2.4).

Para Turkenburg (2000), embora a produção de metanol e hidrogênio, utilizando a tecnologia de gaseificação, tenha recebido bastante atenção no início dos anos 80, o baixo preço do petróleo tornou-os não atrativos na época. No entanto, novas tecnologias de purificação e separação do syngas, somados à produção de eletricidade, podem propiciar baixos custos de produção e uma alta eficiência de conversão (FAllJ et.al, 1999; SPATH \& MANN, 2000). 


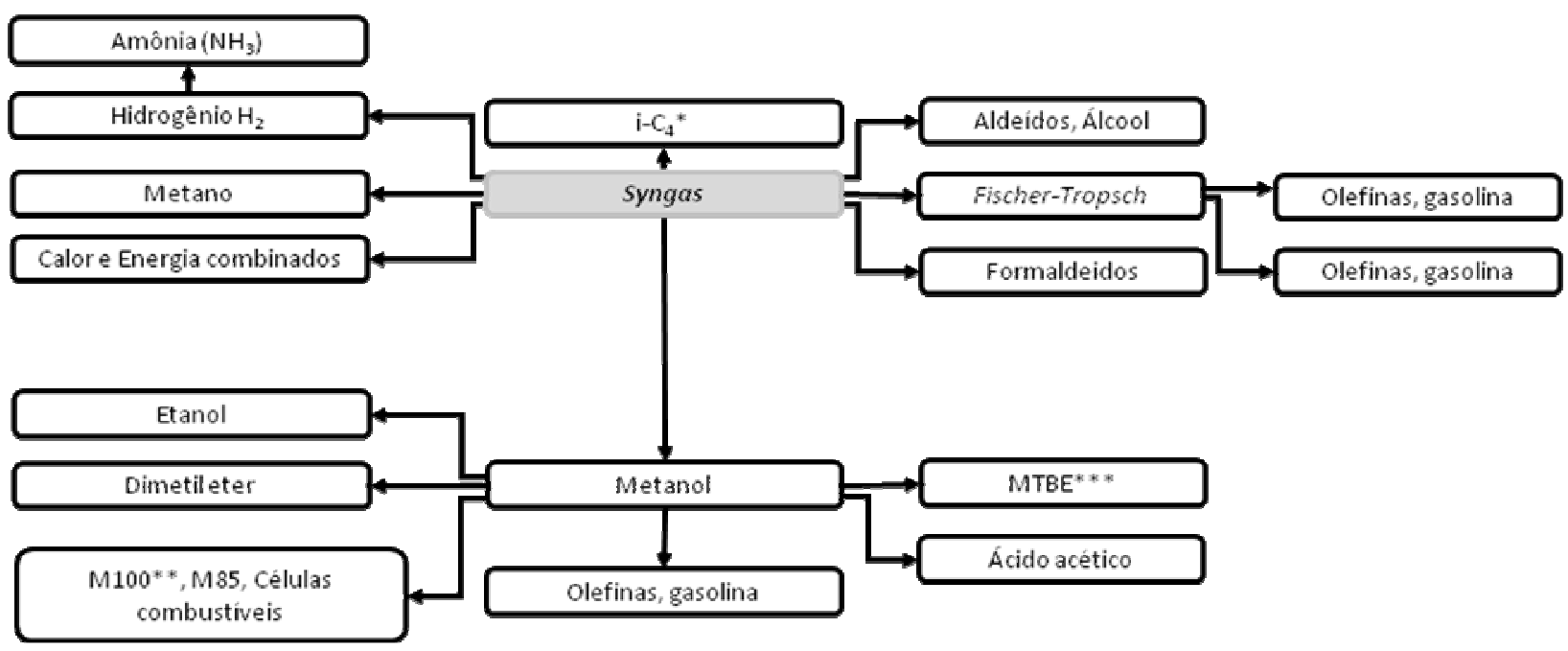

\section{i-C4 combustiveis iso-sintéticos (i-C4hidrocarbonetos)* \\ M100 refere-se a metanol puro, enquanto M855 refere-se a mistura de 15\%vol. de gasolina com 85\% vol. metanol. Esta terminologia geralmente se aplica a metanol usado como combustivel ** MTBE refere-se a metil terc-butil éter, produto da reação do metanol com isobuteno. ${ }^{* * *}$}

Figura 2.4 - Diagrama esquemático da síntese de combustíveis e produtos químicos a partir do syngas (NREL, 2003).

No sentido de aperfeiçoar os processos de produção de hidrogênio e provar sua viabilidade, uma série de esforços em pesquisas tem sido conduzidos para avaliar a produção de hidrogênio via gaseificação, com diferentes tipos de biomassa e sob várias condições de operação (exemplos destas pesquisas podem ser consultados em TANG et. al 2010).

$\mathrm{Ni}$ e colaboradores (2006) relatam que a partir da biomassa é possível alcançar uma eficiência de produção de hidrogênio em torno de $60 \%$, utilizando, por exemplo, gaseificadores de leito fluidizado e de catalisadores adequados. Tal eficiência de conversão, somado aos benefícios ambientais (aproveitamento energético de resíduos, baixa emissões), tem tornado a gaseificação atrativa para a produção renovável de hidrogênio.

Komiyama et. al (2001), por exemplo, apontam um valor de emissões $14 \mathrm{~kg}$ de C/TOC (carbono por toneladas de óleo equivalente) para um sistema de produção de hidrogênio via gaseificação de biomassa, o que representa menos do que $20 \%$ das emissões típicas dos sistemas baseados em combustíveis fósseis. Sob o de vista econômico, Bartels et. al (2010), que estudaram os custos de diferentes rotas de produção de hidrogênio (convencionais e alternativas), indicam que o custo 
esperado da produção de hidrogênio via gaseificação seja de 1,44 USD/kg a 2,83 $\mathrm{USD} / \mathrm{kg}^{2}$.

Embora aspectos sociais, de infraestrutura, tipos de biomassa e condições geográficas afetem os custos da produção, os valores mencionados acima são menores do que as estimativas de produção de hidrogênio via gás natural $(2,48$ USD $/ \mathrm{kg}$ a 3,17 USD/kg). Desta forma, uma vez que a produção de hidrogênio via gaseificação da biomassa é ainda uma tecnologia em desenvolvimento, a expectativa é de que esta torne possível, em um futuro próximo, a produção em larga escala de hidrogênio.

Por outro lado, diversos pesquisadores consideram o hidrogênio obtido a partir da energia solar (hidrogênio solar) ${ }^{3}$ como o vetor energético mais apropriado a longo prazo (ZINI \& TARTARINI, 2009; JOSHI et. al., 2010). Diferente da gaseificação da biomassa, que converte uma fonte de energia solar indireta em vetores energéticos e eletricidade (Figura 2.5), os sistemas de energia solar, particularmente as tecnologias FV, podem converter a irradiação do sol diretamente em energia elétrica.

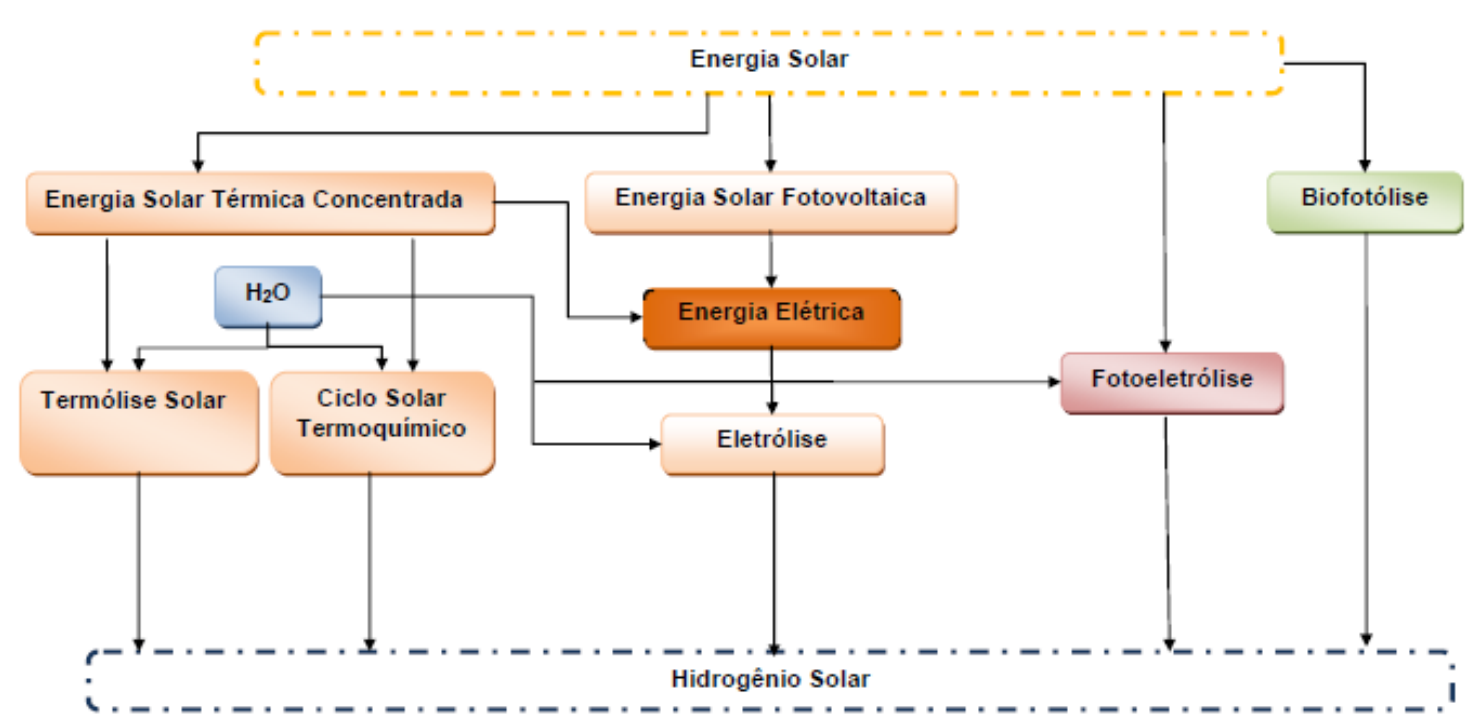

Figura 2.5 - Produção de hidrogênio solar (modificado a partir Joshi et. al, 2010).

\footnotetext{
${ }^{2}$ Valores ajustados para o ano base de 2007. No caso de plantas que utilizam a tecnologia de gaseificação direta é esperado um aumento de $5 \%$ no custo em relação tecnologia de gaseificação indireta.

${ }^{3}$ A produção de hidrogênio usando energia solar pode ser classificada em 4 tipos, nomeadamente: i) fotovoltaica ii) energia térmica solar iii) fotoeletrólise iv) biofotólise.
} 
A combinação da tecnologia fotovoltaica (FV) e a eletrólise configuram-se em um caminho simples de obter a eletricidade e hidrogênio puro (eletrólise da água), a partir da energia solar. Não obstante, destaca-se que o armazenamento de energia, via hidrogênio, pode minimizar a intermitência inerente ao sistema FV e, garantir a continuidade do fornecimento de eletricidade por meio das Células a Combustível (Figura 2.6).

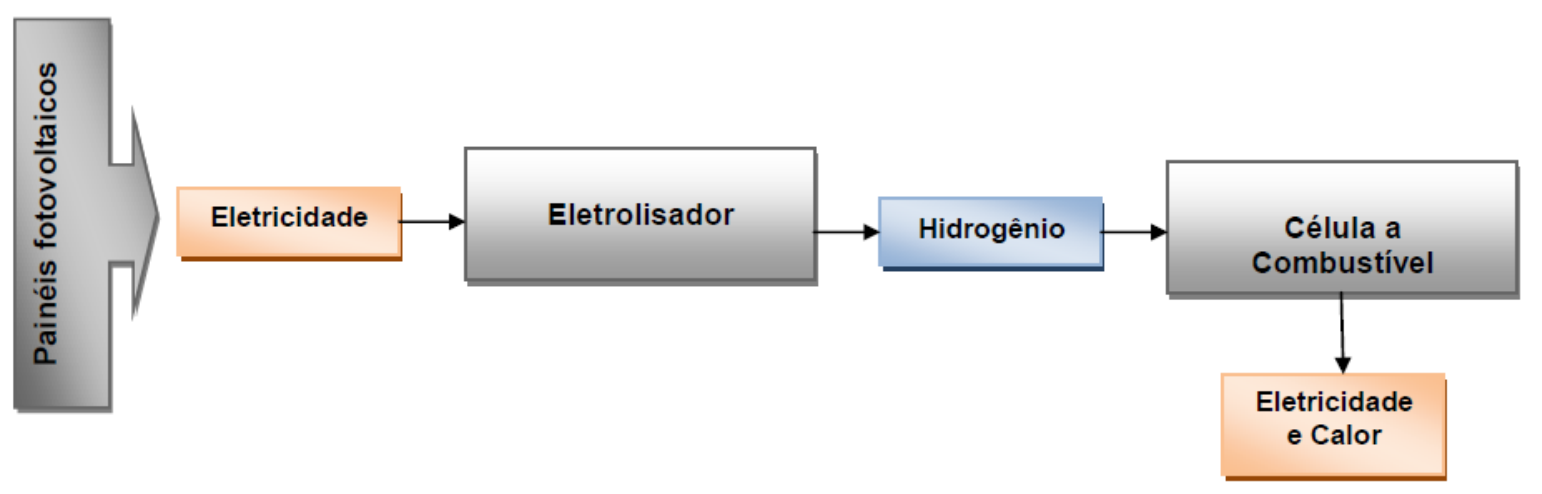

Figura 2.6 - Diagrama esquemático da integração de um sistema FV e de produção de hidrogênio.

No início dos anos 70, a eletricidade gerada pelas células fotovoltaicas foi utilizada para produzir hidrogênio via eletrólise da água. Contudo, por um longo período de tempo, os avanços e a aplicação deste sistema decaíram em virtude da baixa eficiência e do alto custo de manufatura das células FV.

No entanto, o fato da tecnologia FV não emitir gases de efeito estufa (GEE), durante a sua operação, motivaram a continuidade das pesquisas, uma vez que a utilização de energias renováveis (como a solar) tem ganhado significativa importância do ponto de vista ambiental (FUKUROZAKI \& PASCHOAL, 2010).

Isto é, o recente crescimento dos projetos de energia fotovoltaica em escala útil, de políticas agressivas de energia limpa, discussões mais sérias do preço do carbono e a introdução de tarifas de incentivo em diversas nações, motivaram o rápido crescimento da indústria de energia solar e da sua aplicação. Este cenário resultou em significativos avanços nos processos de manufatura das células FV, com ganhos de eficiência e significativos decréscimo do custo.

O baixo custo dos painéis, no qual o valor atual está estimado em torno de 4,83 USD/kWp, tem tornado a produção de hidrogênio a partir da eletrólise via 
FUNDAMENTAÇÃO TÉORICA

\section{FUNDAMENTAÇÃO TÉORICA}

energia solar FV atrativa. Gray \& Tomlinson (2002) estimaram o custo do hidrogênio, a partir da eletrólise via energia fotovoltaica, variando entre 0,98 USD/kg a 6,02 USD $/ \mathrm{kg}$, com um eletrolizador de 231 USD/kW e considerando uma eficiência do painel FV e da eletrólise de 18\% e 85\%, respectivamente. Estes valores podem conduzir ao desenvolvimento de sistemas comerciais a um preço competitivo em relação às fontes tradicionais de energia (BARTELS et. al., 2010).

Exemplos da aplicação atual da energia solar na produção de hidrogênio podem ser verificados em Zini \& Tartarini (2009). Estes autores avaliaram doze plantas (sistema híbrido solar) de produção de hidrogênio e destacaram (considerando as eficiências de conversão) que o uso da energia solar fotovoltaica é uma das melhores opções para a produção de hidrogênio.

Nesta mesma direção, Granoviski et. al (2007), utilizando a análise exergética relatam que, dependendo das taxas de eficiências na $\mathrm{CaC}$, a utilização de hidrogênio solar pode reduzir as emissões dos gases do efeito estufa em até 8 vezes e, a poluição do ar em até 32 vezes. Destarte, tanto a energia solar fotovoltaica, quanto à gaseificação da biomassa apresentam um potencial promissor para a produção de hidrogênio.

Destaca-se que, embora exista uma significativa quantidade de estudos disponíveis na literatura (notoriamente no exterior) sobre a produção de hidrogênio 4 relativos às duas rotas mencionadas acima, a vasta maioria destas publicações restringem-se às análises, tais como a natureza da operação, eficiências de conversão dos sistemas, viabilidade econômica da integração e aplicação no mercado.

Por exemplo, Kalinci et. al (2009) apresentam uma revisão e análise abrangente dos estudos realizados sobre a produção de hidrogênio utilizando a biomassa, conduzidos, até o momento, por pesquisadores de diferentes áreas disciplinares tais como, mecânica, química, biológica e ambiental. Vários métodos de produção de hidrogênio via biomassa, alguns baseados em dados experimentais

\footnotetext{
4 Muitas investigações sobre os vários métodos de produção de hidrogênio têm sido conduzidas nas últimas décadas e estas incluem majoritariamente a produção convencional, ou seja, via fontes não renováveis de energia.
} 
de operação e desempenho, foram revisados e classificados em termos de aplicações.

Dos estudos analisados por Kalinci e colaboradores, alguns focaram nos métodos termoquímicos, outros em métodos bioquímicos (produção de $\mathrm{H}_{2}$ utilizando bactérias) ou ainda, no aumento da eficiência dos parâmetros dos processos ou desenvolvimento de catalisadores. Todos os estudos analisados incluíam a produção de hidrogênio via gaseificação da biomassa. Os resultados alcançados por estes autores destacaram a importância dos parâmetros técnicos na definição do desempenho do sistema de conversão da biomassa.

Do ponto de vista dos sistemas fotovoltaicos, destaca-se o estudo realizado por Bolton (1996), que analisou as diferentes opções tecnológicas de produção de hidrogênio solar. Ao mensurar as eficiências dos processos produtivos disponíveis, Bartels enfatizou que apenas quatro métodos apresentam suficiente expectativa que justifica os investimentos em pesquisa e desenvolvimento (P\&D), a saber: sistemas híbridos (painel fotovoltaico/ eletrolisador), células fotoeletroquímicas, sistemas fotobiológicos e os fotodegradativos.

Recentemente, os dados de eficiência energética de sistemas solar híbridos foram atualizados por Zini \& Tartarine (op. cit, 2009). Estes autores analisaram sistemas híbridos reais e simulados, concluindo, dentre outros, que a conversão de energia do sistema - energia fotovoltaica/ eletrolisador/armazenamento de $\mathrm{H}_{2}$ / célula a combustível - é muito mais complexa do que o fornecimento direto do vetor energético. No entanto, esta configuração evita as perdas no fornecimento e permite a estocagem de energia por longos períodos.

$\mathrm{Na}$ esfera econômica, Bartels et. al (op cit., 2010) trazem uma recente e consolidada avaliação comparativa dos custos da produção de hidrogênio,via fontes convencionais (recursos fósseis) e alternativas, tais como, eólica, solar, biomassa e nuclear. Os custos reportados na publicação foram originalmente obtidos dos estudos empregados para elaborar o Índice de Custo de Plantas de Engenharia Química - Chemical Engineering Plant Cost Index, no qual estão inclusos os custos de equipamentos, da construção, edificação, engenharia e supervisão das plantas químicas. Nesta avaliação, Bartels e colaboradores constataram que, apesar do 
elevado custo das fontes alternativas, estas poderão ser mais econômicas no futuro à medida que avançar o desenvolvimento tecnológico e aumentarem os custos de energia fóssil.

Em contraste ao quadro acima, poucas são as investigações que se dedicam a avaliar as variáveis ambientais com foco na identificação e análise dos impactos, de forma a propiciar uma análise comparativa, não somente dos parâmetros operacionais (tais como os citados anteriormente), como também dos fatores ambientais. Indubitavelmente, para promover a sustentabilidade dos sistemas energéticos renováveis, os fatores ambientais que influenciam o seu desempenho são essenciais na definição de políticas públicas, desenvolvimento de rotas tecnológicas, investimentos e aplicação no mercado.

No que tange à produção de hidrogênio via gaseificação da biomassa destacam-se os estudos realizados por Komiyama e colaboradores (2010) e o de Koroneos et. al (2009). Nestes estudos, a metodologia de Avaliação do Ciclo de Vida (ACV) foi empregada para avaliar os aspectos ambientais dos sistemas de conversão de biomassa. O primeiro estudo enfocou a análise energética e de custos, enquanto o segundo identificou os potenciais impactos. Ressalta-se, no entanto, que dada às diferenças existentes no tratamento dos dados e na ausência de informações suficientes, as comparações entre os sistemas são difíceis de executar e, não obstante, não propiciam uma análise, deste tipo, consistente.

Referente aos sistemas fotovoltaicos há uma grande quantidade de trabalhos com foco na análise ambiental, utilizando diferentes abordagens metodológicas, destacando-se, entre elas, a ACV. Especificamente, em relação aos sistemas de produção de hidrogênio solar, observa-se comumente a utilização da análise exergética. Em Joshi et. al (2010), por exemplo, diferentes processos de produção de hidrogênio solar são avaliados e as vantagens e desvantagens são comparadas em termos de exergia e fator de sustentabilidade. Neste estudo, a eletrólise da água usando painéis fotovoltaicos apresentou o maior índice.

Especialmente no Brasil, tais publicações são ainda inexistentes, inclusive no que refere às análises ambientais abrangentes (como a fornecida pela ACV), específicas dos sistemas de gaseificação e energia fotovoltaica atualmente em 
FUNDAMENTAÇÃO TÉORICA

FUNDAMENTAÇÃO TÉORICA

operação no país. Isto por sua vez, enfatiza a necessidade e a importância de uma avaliação compreensiva dos impactos ambientais utilizando a abordagem do ciclo de vida.

Neste sentido, os próximos três capítulos apresentam com maior profundidade, as características de cada recurso, as tecnologias aplicadas, os impactos resultantes da cadeia produtiva e as variáveis econômicas dos sistemas de gaseificação da biomassa e de energia solar. Por último, é apresentada a metodologia de ACV empregada no presente estudo, incluindo os procedimentos específicos de tratamento dos dados. 


\section{FUNDAMENTAÇÃO TÉORICA}

\section{BIOMASSA}

\subsection{Recurso e Potencial Energético}

Do ponto de vista energético e para fins de outorga de empreendimentos do setor elétrico, a Agência Nacional de Energia Elétrica - ANEEL (2005, p. 77) define a biomassa como "todo recurso renovável oriundo de matéria orgânica (de origem animal ou vegetal) que pode ser utilizada na produção de energia". Tal como a energia hidráulica e outras fontes renováveis, a biomassa é uma forma indireta de energia solar. Através da fotossíntese, base dos processos biológicos de todos os seres vivos, a energia solar é convertida em energia química.

Brás et. al. (2007, p. 24) definem a biomassa como "a fração biodegradável de produtos e resíduos da agricultura (incluindo substâncias vegetais e animais), da floresta e das indústrias conexas, bem como a fração biodegradável dos resíduos industriais e urbanos". Desta forma, a biomassa pode ser considerada como uma fonte de energia derivada de:

- Produtos e dos subprodutos da floresta;

- Resíduos da indústria da madeira;

- Resíduos de culturas agrícolas;

- Efluentes domésticos;

- Instalações agropecuárias e de indústrias agro-alimentares (lacticínios, matadouros, entre outros);

- Culturas energéticas e;

- Resíduos sólidos urbanos.

Uma das principais vantagens da biomassa é que, embora de eficiência reduzida, seu aproveitamento pode ser realizado diretamente, por exemplo, pelo intermédio da combustão em fornos e caldeiras a vapor. Para aumentar a eficiência do processo e reduzir impactos socioambientais tem-se desenvolvido e aperfeiçoado tecnologias de conversão mais eficientes, como a gaseificação e a pirólise, também sendo comum o uso da cogeração em sistemas que utilizam a biomassa como fonte energética.

No médio e longo prazo, a exaustão de fontes não renováveis e as pressões ambientalistas poderão acarretar maior aproveitamento energético da biomassa. Atualmente, a biomassa vem sendo cada vez mais utilizada na geração de 
eletricidade, principalmente em sistemas de cogeração e no suprimento de eletricidade para demandas isoladas da rede elétrica (ANEEL, 2005).

Segundo Hall, House \& Scrave (2005), nos anos 90, foram publicados vários estudos envolvendo cenários globais de energia que incluem questões como eficiência na produção e consumo, bem como as energias renováveis. Parte desses estudos abordou a biomassa e previu importantes participações no fornecimento de bioenergia.

A tabela 3.1 apresenta as estimativas para o uso de biomassa no futuro, a partir dos estudos analisados por esses autores. Os dados devem ser comparados com o total de energia usada atualmente, de aproximadamente $400 \mathrm{EJ}\left(10^{18}\right.$ joule), dos quais cerca de 55 EJ são obtidos a partir da biomassa, na sua maioria utilizada na forma de fontes tradicionais de energia.

Tabela 3.1. - Estimativa de uso de energia da biomassa no suprimento global de energia no futuro $\left(10^{18} \mathrm{~J}\right)$ (HALL, HOUSE \& SCRAVE, 2005).

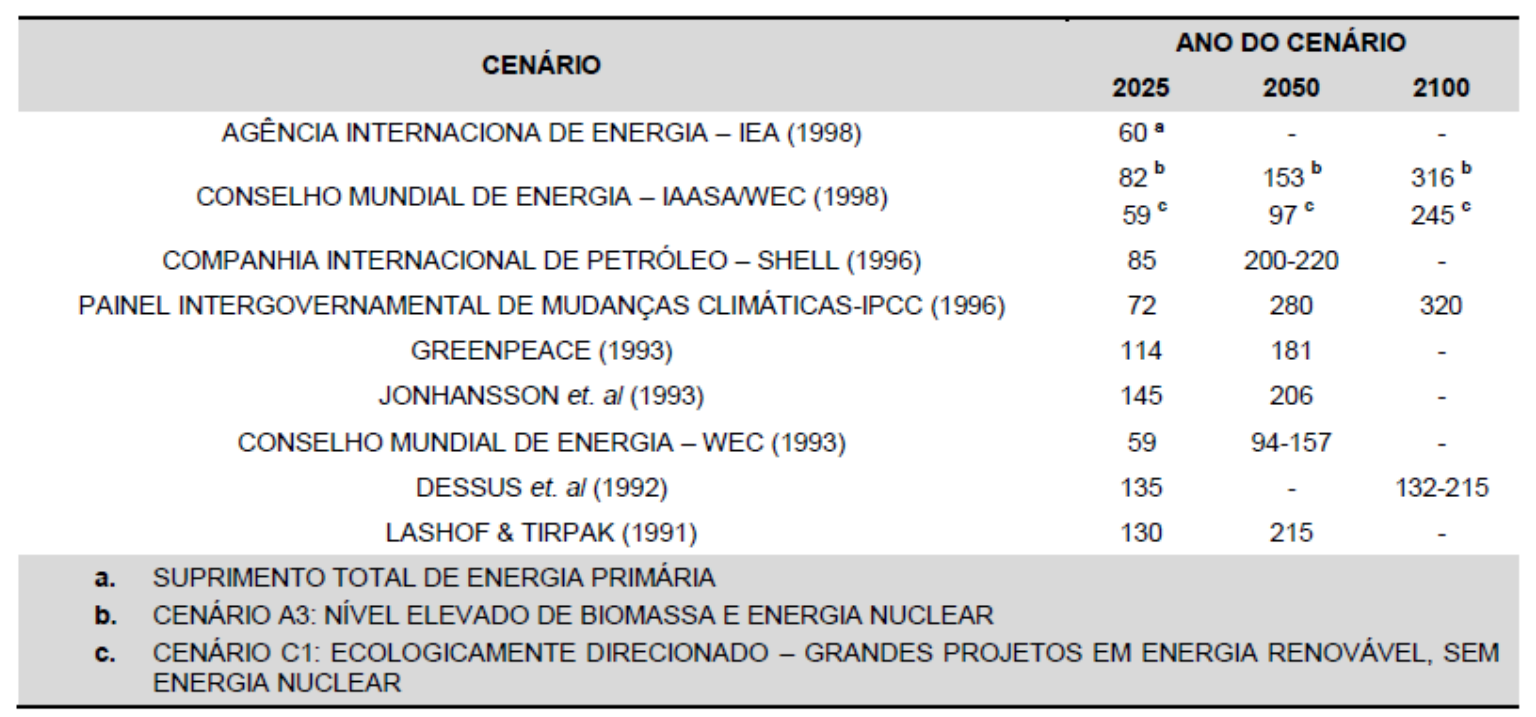

A expectativa de maior participação da biomassa no suprimento de energia no futuro pode ser explicada por vários motivos. Para Hall, House \& Scrase (2005), três aspectos são destacados. Primeiro, os combustíveis derivados da biomassa podem substituir direto ou indiretamente os combustíveis fósseis na atual infraestrutura de suprimento de energia. Em segundo, os potenciais recursos são abundantes, uma vez que há disponibilidade de terras. As terras não destinadas à plantação de alimentos e produtos agrícolas continuam a expandir-se mais do que a taxa de crescimento demográfico. Por fim, nos países em desenvolvimento, a 
demanda de energia está crescendo rapidamente devido ao crescimento da polução, à urbanização acelerada e à melhoria nos padrões de qualidade de vida.

De acordo com a Federação de Indústrias do Estado de São Paulo (FIESP/CIESP, 2001), no Brasil, a imensa superfície do território nacional, quase todo localizado em regiões tropicais e chuvosas, oferece excelentes condições para a produção e o uso energético da biomassa em larga escala. Além da fabricação do etanol, queima em fornos, caldeiras e outros usos não comerciais, a biomassa apresenta grande potencial no setor de geração de energia elétrica. Em 2005, a oferta interna de energia oriunda da biomassa no Brasil foi de 65,8. $10^{6}$ tep (toneladas equivalentes de petróleo) (MME, 2006).

Especificamente, em São Paulo é intensa a geração de biomassa energética por meio da cana-de-açúcar, sendo comparável à produção hidráulica. O Estado é importador de $40 \%$ de eletricidade e exportador de etanol para o país. Constata-se, portanto, que apesar do cultivo da biomassa energética ser uma atividade mundialmente considerada como extremamente demandante de terras, é possível encontrar áreas para essa atividade mesmo numa região com alta densidade demográfica (COELHO, 2002).

Além disso, o setor sucroalcooleiro brasileiro gera uma grande quantidade de resíduos - bagaço, palha, entre outros - que podem ser aproveitados na geração de eletricidade, principalmente em sistemas de cogeração. Ao contrário da produção de madeira, o cultivo e o beneficiamento da cana são realizados em extensões contínuas e o aproveitamento é facilitado pela centralização dos processos de produção.

Atualmente, o recurso (biomassa) de maior potencial para a geração de energia elétrica no Brasil é a cana-de-açúcar. A alta produtividade alcançada pela lavoura canavieira, acrescida dos ganhos sucessivos nos processos de transformação dessa biomassa, tem disponibilizado enorme quantidade de matéria orgânica, sob a forma de bagaço e palha, nas usinas e destilarias de cana-de-açúcar (FIESP/CIESP, 2001).

Ademais, estudos realizados pelo Centro de Referência em Biomassa CENBIO (2007) destacam a cana de açúcar como a fonte de biomassa com alto potencial para produção de energia em relação aos outros resíduos, tais como 
agrícolas (casca de arroz, de castanha de caju e do coco- da- baía), os urbanos (lodo da estação de tratamento de esgoto e resíduos sólidos municipais), da suinocultura e silvicultura, entre outros.

Conforme Johnson (2006), a conversão da biomassa para combustíveis (ou outros produtos industriais) decorre por meio de três tipos primários de processos: bioquímicos, termoquímicos e conversão mecânica, os quais apresentam várias alternativas tecnológicas, que na sua maioria resultam em produtos específicos combustíveis químicos ou eletricidade. Algumas opções de processos são específicos para os diferentes tipos de recursos de biomassa, outros podem servir a maioria. A figura 3.1 apresenta as principais fontes de biomassa, os processos de conversão e o produto energético.

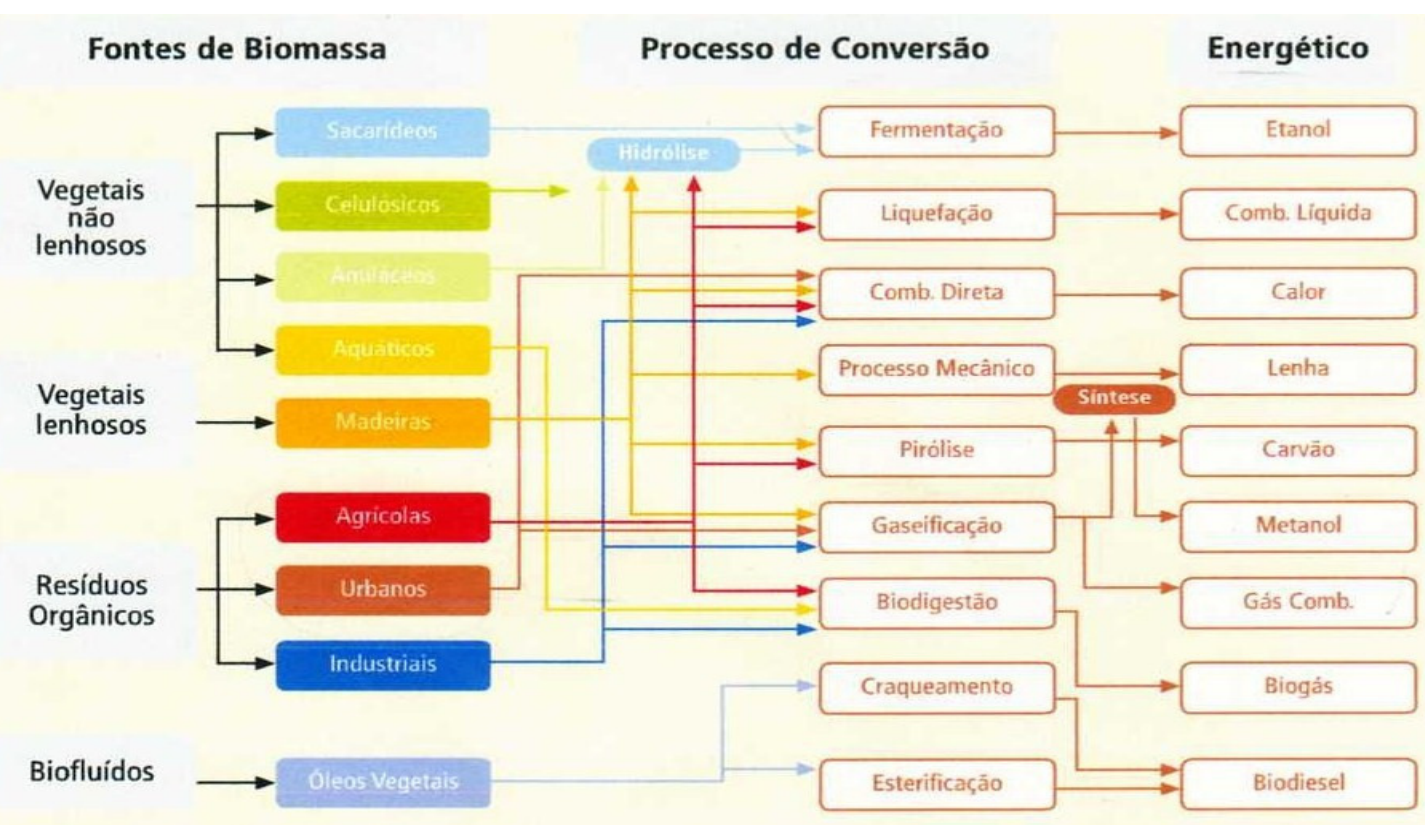

Figura 3.1 - Diagrama esquemático dos processos de conversão energética da biomassa (Balanço Energético Nacional - BEN. Brasília, MME, 1982 (adaptado) apud ANEEL, 2005).

$\mathrm{Na}$ visão de Faaij e colaboradores (2005), o crescimento da concorrência entre as empresas geradoras e distribuidores de energia, bem como a crescente consciência da sociedade para com a conservação ambiental e o uso sustentável dos recursos naturais, são fatores determinantes na promoção de profundas alterações no setor energético.

Neste caminho, as perspectivas futuras para biomassa voltam-se claramente para os vetores energéticos modernos: o uso dos combustíveis líquidos e gasosos, 
como o etanol e o hidrogênio, em substituição ao uso direto de combustíveis fósseis. Uma das tecnologias utilizadas para quebrar a estrutura molecular da biomassa e produzir hidrogênio, provavelmente mais próxima de ser competitiva em relação aos sistemas convencionais (reforma a vapor e eletrólise), está relacionada aos processos termoquímicos da gaseificação e da pirólise (NREL, 2003).

\subsection{Processos Termoquímicos de Conversão da Biomassa}

Por meio da gaseificação da biomassa é possível converter um material muito heterogêneo em combustível gasoso rico em carbono e hidrogênio, em geral, facilmente utilizados com ganhos na eficiência e no desempenho ambiental em comparação a combustão direta da biomassa. Os sistemas de gaseificação compreendem o sistema de manuseio da biomassa e o da alimentação, conectados ao gaseificador por meio de retentores de ar. $O$ gaseificador é revestido com material refratário e a gaseificação geralmente ocorre em altas temperaturas, sob condições de pressão atmosférica ou sob elevada pressão.

O processo de gaseificação pode ser entendido como uma conversão semelhante à combustão, mas com menos oxigênio disponível do que o necessário para a queima completa. A razão entre o oxigênio disponível e a quantidade de oxigênio necessária para a combustão completa é denominada de relação de equivalência.

Para uma relação de equivalência ${ }^{1}$ abaixo de 0,1 , o processo é denominado pirólise e, somente uma modesta fração de energia da biomassa é encontrada nos produtos gasosos, o restante encontra-se na forma de cinzas e óleos residuais. Se a relação de equivalência encontra-se entre 0,2 e 0,4, o processo é propriamente conhecido como gaseificação, no qual o máximo de energia é transferida para os gases produzidos (REED, 1981).

A tabela 3.2 lista um número de reações envolvendo um material polissacarídeo e as mudanças de energia estimadas para a conversão térmica da celulose, incluindo os processos de pirólise e gaseificação. Para a celulose, considerada na tabela 3.2, a relação de carbono, hidrogênio e oxigênio são 1: 1,4: 0,6 .

\footnotetext{
${ }^{1}$ Relação da atual massa de oxigênio injetado no reator na forma de ar para a massa de oxigênio que deverá ser necessária para a estequiometria de combustão do combustível.
} 
O gás produzido pela gaseificação da biomassa é em si mesmo um gás de média qualidade (com valores de queima em torno de 10-18 $\mathrm{MJ} \mathrm{m}^{-3}$ ), que pode ser utilizado diretamente em motores a diesel ou de ciclo Otto. Contudo, se o propósito é o de servir como fonte de hidrogênio, o gás precisa adquirir a qualidade do gás das linhas de distribuição (cerca de $30 \mathrm{MJ} \mathrm{m}^{-3}$ ) e a pureza do hidrogênio depende da aplicação desejada. Para tipos complexos de biomassa, como resíduos urbanos ou da agricultura, a gaseificação apresenta um gás com menor quantidade de hidrogênio (20 a 25\%), que requer adicionais reações ou etapas de purificação (MÉRIDA et. al, 2004).

Tabela 3.2 - Mudança de energia nas reações de conversão térmica estimadas para celulose (SORESEN, 2005).

\begin{tabular}{|c|c|c|}
\hline REAÇÃO QUÍMICA & $\begin{array}{c}\text { ENERGIA } \\
\text { CONSUMIDA } \\
\left(\mathbf{k J g}^{-1}\right)^{\text {a }}\end{array}$ & PRODUTOS/PROCESSOS \\
\hline $\mathrm{C}_{6} \mathrm{H}_{10} \mathrm{O}_{5} \Rightarrow 6 \mathrm{C}+5 \mathrm{H}_{2}+2,5 \mathrm{O}_{2}$ & $5,94^{b}$ & ELEMENTOS, DISSOCIAÇÃO \\
\hline $\mathrm{C}_{6} \mathrm{H}_{10} \mathrm{O}_{5} \Rightarrow 6 \mathrm{C}+5 \mathrm{H}_{2} \mathrm{O}(\mathrm{g})$ & $-2,86$ & CARVÃO, CARREAMENTO \\
\hline $\mathrm{C}_{6} \mathrm{H}_{10} \mathrm{O}_{5} \Rightarrow 0,8 \mathrm{C}_{6} \mathrm{H}_{8}+1,8 \mathrm{H}_{2} \mathrm{O}(\mathrm{g})+1,2 \mathrm{CO}_{2}$ & $-2,07^{c}$ & ÓLEOS RESÍDUAIS, PIRÓLISE \\
\hline $\mathrm{C}_{6} \mathrm{H}_{10} \mathrm{O}_{5} \Rightarrow 2 \mathrm{C}_{2} \mathrm{H}_{4}+2 \mathrm{CO}_{2}+\mathrm{H}_{2} \mathrm{O}(\mathrm{g})$ & 0,16 & ETILENO, PIRÓLISE RÁPIDA \\
\hline $\mathrm{C}_{6} \mathrm{H}_{10} \mathrm{O}_{5}+1 / 2 \mathrm{O}_{2} \Rightarrow 6 \mathrm{CO}+5 \mathrm{H}_{2}$ & 1,85 & GÁS DE SIINTESE, GASEIFICAÇAO \\
\hline $\mathrm{C}_{6} \mathrm{H}_{10} \mathrm{O}_{5}+6 \mathrm{H}_{2} \mathrm{O} \Rightarrow 6 \mathrm{CH}_{2}+5 \mathrm{H}_{2} \mathrm{O}(\mathrm{g})$ & $-4,86^{d}$ & HIDROCARBONETOS, GERAÇÃO \\
\hline $\mathrm{C}_{6} \mathrm{H}_{10} \mathrm{O}_{5}+6 \mathrm{O}_{2} \Rightarrow 6 \mathrm{CO}_{2}+5 \mathrm{H}_{2} \mathrm{O}(\mathrm{g})$ & $-17,48$ & CALOR, COMBUSTÃO \\
\hline \multicolumn{3}{|c|}{$\begin{array}{l}\text { a. Calor específico da reação } \\
\text { b. O negativo do calor convencional formado é calculado para a celulose a partir do calor de combustão do amido } \\
\text { c. Calculado a partir dos dados da pirólise do óleo } \mathrm{C}_{6} \mathrm{H}_{8} \mathrm{O}\left(\Delta \mathrm{H}_{\mathrm{c}}=-745,9 \mathrm{kcal} \mathrm{mol}{ }^{-1}, \Delta \mathrm{H}_{\mathrm{f}}=149,6 \mathrm{kcal} \mathrm{g}^{-1} \text {, onde } \mathrm{H}_{\mathrm{c}}=\right. \\
\text { calor da combustão e } \mathrm{H}_{\mathrm{f}}=\text { calor de fusão) } \\
\text { d. Calculado para o hidrocarboneto com } \Delta \mathrm{H}_{\mathrm{c}} \text { como acima. O hidrogênio é consumido. }\end{array}$} \\
\hline
\end{tabular}

Nas aplicações em células a combustível, é necessário que o gás tenha alto teor de hidrogênio e não esteja contaminado por enxofre, cloro e monóxido de carbono para assegurar a proteção dos eletrodos, bem como também se faz necessário à remoção de particulados e substâncias como $\mathrm{CO}$ e ácido sulfúrico para evitar o envenenamento dos catalisadores.

Células a combustível de alta temperatura, como a de carbonato fundido Molten Carbonate Fuel Cell (MCFC) e a célula de óxido sólido - Solid Oxide Fuel Cell (SOFC) são consideradas as opções mais promissoras para a integração com os sistemas de gaseificação, principalmente por não ser necessário à adequação de CO na composição do gás e, visto que as células de baixa temperatura, como a de membrana trocadora de prótons - PEMFC, somente toleram níveis de $\mathrm{CO}$ abaixo de algumas partes por milhão (KALTSCHMITT et. al., 1998). 
De acordo com Faaij et. al. (2005), a eficiência térmica da gaseificação é de 80 a $85 \%$, avaliada pela energia de mistura do gás combustível em relação ao conteúdo da matéria prima. Estima-se uma eficiência final da conversão da biomassa em eletricidade superior a $45 \%$, com o uso dos ciclos combinados de geração de eletricidade. Se os gases forem convertidos em hidrogênio, a eficiência máxima com o emprego de células a combustível pode ser superior a 55\% (base do poder calorífico superior).

Neste caso, a vantagem ambiental é que o volume do gás combustível é bem menor do que o do gás de combustão que sai da caldeira. Tal aspecto associado à temperatura, geralmente baixa de tratamento da biomassa, resultam na retenção de metais (inclusive álcalis), como sais, nas cinzas e no ciclone, que não podem ser descartados. Os componentes gasosos ácidos, como o ácido clorídrico, podem ser facilmente retirados do gás antes da combustão e, por isso, a gaseificação é ambientalmente superior à combustão direta.

\subsubsection{Princípios de Funcionamento da Gaseificação e Pirólise}

A gaseificação consiste de uma série de distintos processos: aquecimento e secagem do combustível; pirólise do combustível sólido em gases, condensação de vapores e materiais carbonáceos, reações sólido-gás que consumem os materiais carbonáceos, e a fase de reações do gás que ajustam a composição química do syngas.

A pirólise, que inicia-se entre $300^{\circ}$ e $400^{\circ} \mathrm{C}$, pode converter mais de $80 \%$ da biomassa sólida em gases e vapores. Os gases pirolíticos incluem $\mathrm{CO}, \mathrm{CO}_{2}, \mathrm{H}_{2}, \mathrm{H}_{2} \mathrm{O}$ e metano, enquanto os vapores condensados incluem uma variedade de hidrocarbonetos e compostos orgânicos oxigenados. As reações sólido-gás produzem $\mathrm{CO}, \mathrm{H}_{2}$ e $\mathrm{CH}_{4}$, seguido das seguintes reações (REED, 1981):

I. Reação carbono-oxigênio:

$$
\mathrm{C}+1 / 2 \mathrm{O}_{2} \leftrightarrow \mathrm{CO} \quad \Delta \mathrm{HR}=-110.5 \mathrm{MJ} / \mathrm{kmol}
$$

II. Reação redox (equilíbrio químico):

$$
\mathrm{C}+\mathrm{CO}_{2} \leftrightarrow 2 \mathrm{CO}
$$$$
\Delta \mathrm{HR}=172,4 \mathrm{MJ} / \mathrm{kmol}
$$

III. Reação carbono-água: 


$$
\mathrm{C}+\mathrm{H}_{2} \mathrm{O} \leftrightarrow \mathrm{H}_{2}+\mathrm{CO} \quad \Delta \mathrm{HR}=131,3 \mathrm{MJ} / \mathrm{kmol}
$$

IV. Reação de hidrogenação

$$
\mathrm{C}+2 \mathrm{H}_{2} \leftrightarrow \mathrm{CH}_{4} \quad \Delta \mathrm{HR}=-74,8 \mathrm{MJ} / \mathrm{kmol}
$$

Duas importantes reações da fase de gás também influenciam todo o processo de gaseificação:

I. Reação shiftágua-gás:

$$
\mathrm{CO}+\mathrm{H}_{2} \mathrm{O} \leftrightarrow \mathrm{H}_{2}+\mathrm{CO}_{2} \quad \Delta \mathrm{HR}=-41.1 \mathrm{MJ} / \mathrm{kmol}
$$

II. Metanização:

$$
\mathrm{CO}+3 \mathrm{H}_{2} \leftrightarrow \mathrm{CH}_{4}+\mathrm{H}_{2} \mathrm{O} \quad \Delta \mathrm{HR}=-206.1 \mathrm{MJ} / \mathrm{kmol}
$$

A composição do gás é fortemente dependente da quantidade de oxigênio e vapor admitidos para o reator, assim como o tempo e a temperatura de reação. $O$ equilíbrio químico é alcançado em reações de tempos relativamente longos e os produtos são essencialmente limitados a gases leves como $\mathrm{CO}, \mathrm{CO}_{2}, \mathrm{H}_{2}$ e $\mathrm{CH}_{4}(\mathrm{e}$ nitrogênio, se o ar foi usado como fonte de oxigênio).

Conforme Brown (2005), temperaturas do gaseificador e tempos de reação geralmente não são suficientes para atingir o equilíbrio químico e o produto, syngas bruto contém normalmente hidrocarbonetos leves como $\mathrm{C}_{2} \mathrm{H}_{2}$ e $\mathrm{C}_{2} \mathrm{H}_{4}$, como também, mais de $10 \%$ da massa total na forma de hidrocarbonetos pesados, condensados em um líquido preto, viscoso, conhecido como alcatrão.

Ainda, dois tipos de materiais particulados contaminam o gás. O primeiro, conhecido como cinza é um material mineral das sobras da biomassa bruta remanescente da completa gaseificação. $O$ segundo, são os materiais carbonáceos formado durante a pirólise, mas que não é consumido nas reações sólido-gás. Juntos, esses materiais e a cinza são referenciados, muitas vezes, como cinza ou resíduos da gaseificação.

\subsection{Tecnologias de Conversão}

Os gaseificadores são geralmente classificados de acordo com o método de contato do combustível e o gás (QUAAK et.al, 1998). Brown (2005) destaca três tipos apropriados para gaseificação da biomassa: 


\section{FUNDAMENTACC̃̃O TÉORICA}

- Gaseificador de leito fixo de fluxo ascendente ou contracorrente - updraft;

- Gaseificador fixo de fluxo descendente ou concorrente - downdraft,

- Gaseificador de leito fluidizado.

\subsubsection{Gaseificadores de Leito Fixo}

Os gaseificadores de fluxo ascendente são os mais antigos e mais simples. Caracteriza-se por um reator de contracorrente, no qual o combustível é introduzido na parte superior por meio de um silo com válvulas de retenção, fluindo para baixo por todo o reator até uma grelha da qual a cinza é removida. O meio de gaseificação, ar ou oxigênio e, possivelmente, o vapor é introduzido abaixo da grelha, fluindo para cima, por todo o gaseificador. Geralmente, a temperatura de saída do gás produzido encontra-se entre 80 a 100ํ(Figura 3.2).

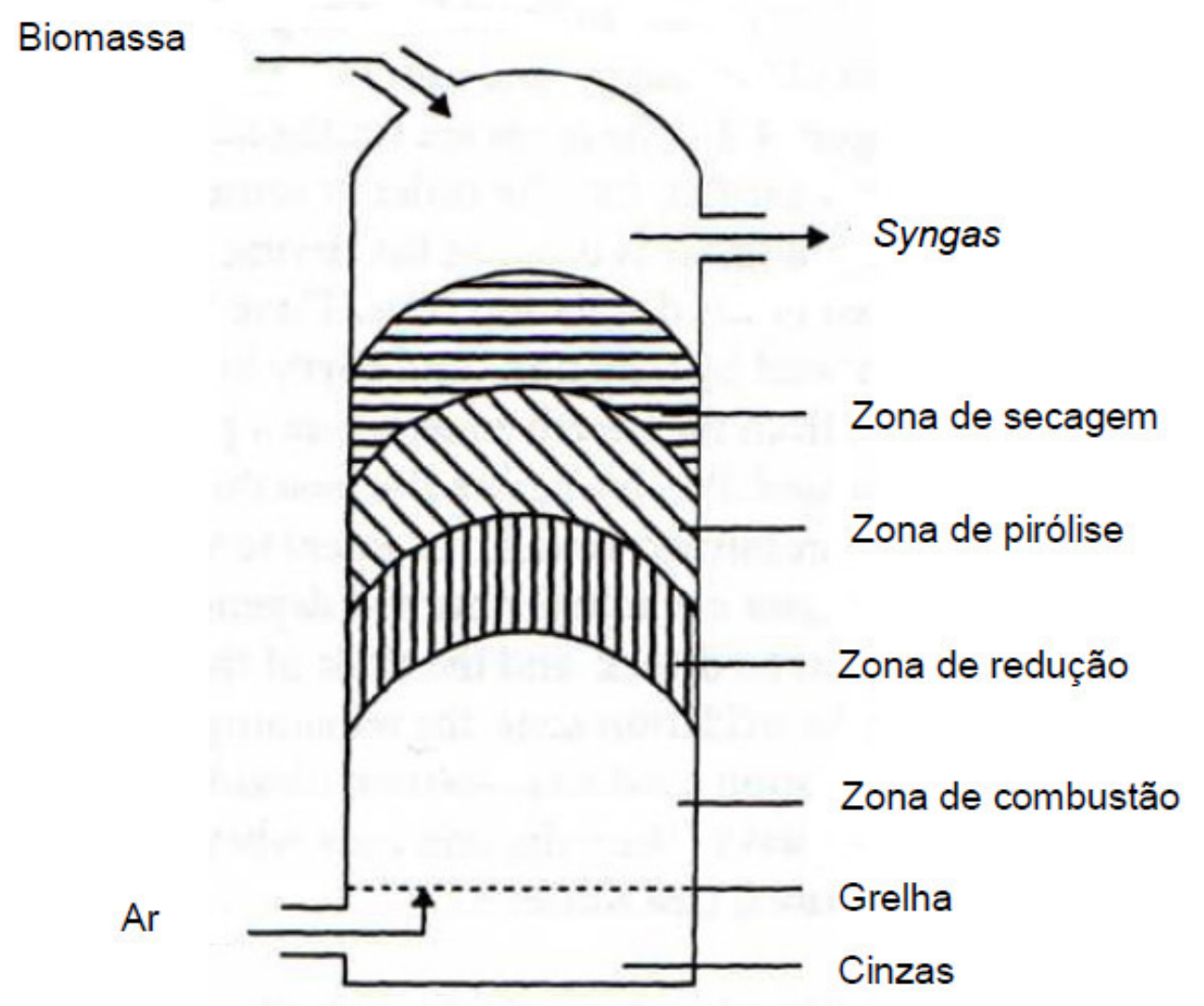

Figura 3.2- Gaseificador de leito fixo, fluxo ascendente ou contracorrente (FAO, 1986).

Na zona de pirólise, uma grande variedade de alcatrões e óleos podem se condensar na tubulação de transporte. Assim como, determinadas matérias primas, que produzem cinzas com baixo ponto de fusão, podem gerar escória na grelha de 


\section{FUNDAMENTAÇÃO TÉORICA}

combustão. Por essa razão, esse tipo de gaseificador é geralmente acoplado a um forno ou caldeira. No caso de utilização do gás produzido em equipamentos de combustão interna, um extensivo processo de limpeza do gás torna-se necessário (QUAAK et. al, 1998).

Por outro lado, Quaak et. al (1998) destacam que as maiores vantagens do gaseificador contracorrente é a simplicidade e a troca interna de calor que conduz a uma saída de gás a baixa temperatura e uma gaseificação de alta eficiência. Devido a esta troca, a secagem do combustível (biomassa) ocorre no topo do equipamento, o que por sua vez, permite o uso de combustíveis com alto conteúdo de base úmida (até $60 \%$ ). Ademais, este tipo de gaseificador permite processar combustíveis com certa variação de tamanho, incluindo partículas relativamente pequenas.

Já os gaseificadores de fluxo descendente, o ar e o gás produzido fluem na mesma direção que o leito sólido. Esses equipamentos são especificamente projetados para reduzir a formação de alcatrão e óleo. O combustível e os vapores pirolíticos fluem para baixo através do leito e a temperatura de saída do gás é de aproximadamente $700^{\circ} \mathrm{C}$.

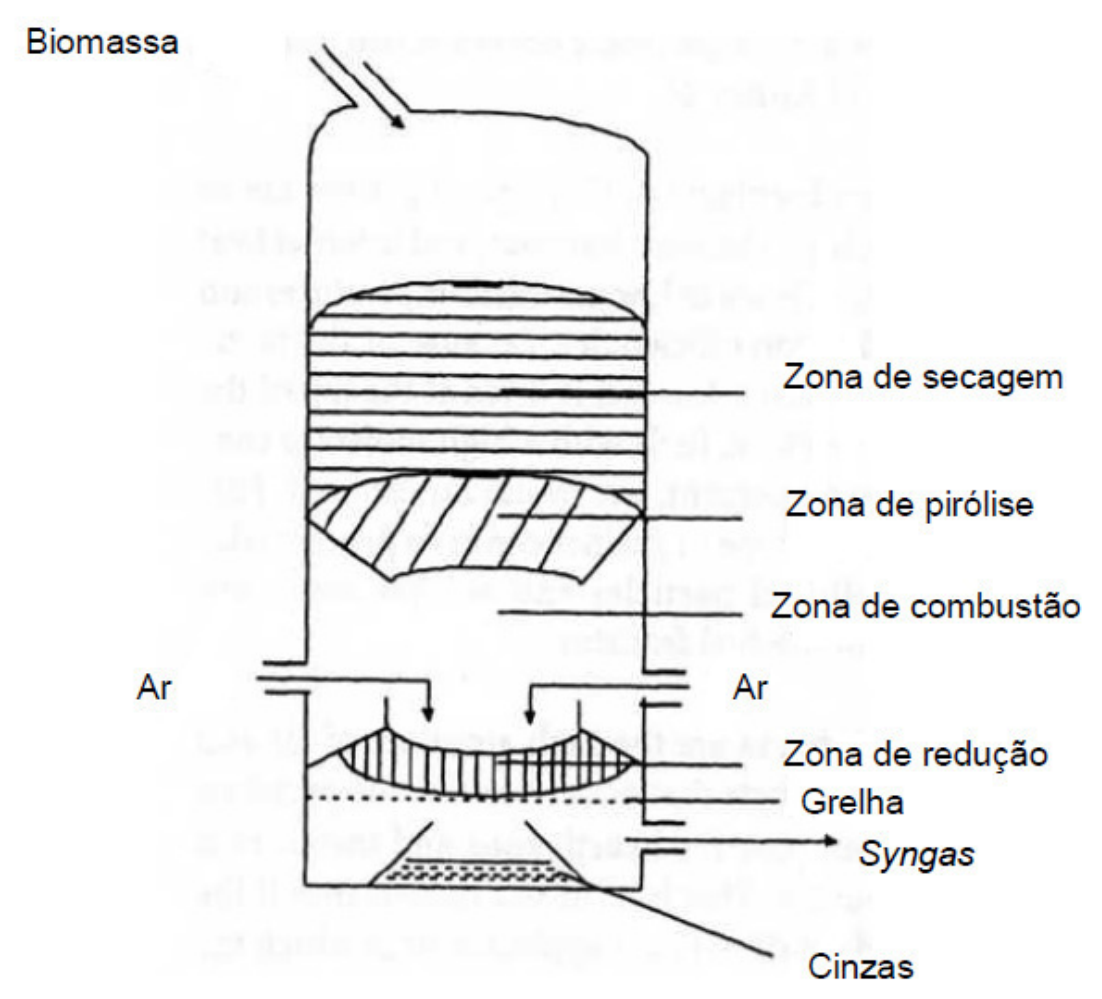

Figura 3.3- Gaseificador de leito fixo, fluxo descendente ou concorrente (FAO, 1986). 


\section{FUNDAMENTAÇÃO TÉORICA}

Quanto às propriedades da matéria prima de alimentação, esta deve ter preferencialmente baixo teor de cinzas, alta temperatura de fusão e um teor da umidade menor que $20 \%$, para manter a temperatura necessária ao craqueamento do alcatrão (FAAlJ et. al, 2005). O gaseificador concorrente (ou fluxo descendente) apresenta como principal vantagem produzir um gás de baixo teor de alcatrão, portanto mais apropriado para motores de combustão interna. Na prática, contudo, um gás livre de alcatrão pode ocorrer eventualmente. Quaak e colaboradores (1998) indicam que a principal razão para tal ocorrência é de que o tempo de residência dos gases na zona de combustão é muito curto.

Segundo Quaak et.al (2000), a distribuição de gaseificadores comercializados no mercado (Europa, Estados Unidos e Canadá), conforme o projeto da planta (potência) e o tipo de reator (tecnologia), corresponde a 77,5\% para gaseificadores de leito fixo (concorrente e contracorrente), $20 \%$ de leito fluidizado e $2,5 \%$ para outras tecnologias.

Em geral, os gaseificadores de leito fixo (LFX) são mais apropriados para baixa capacidade de geração (< $10 \mathrm{MW}_{\text {th }}$ ), enquanto os de leito fluidizado (LFL) são mais adequados para alta capacidade $\left(>10 \mathrm{MW}_{\text {th }}\right)$. A figura 3.4 apresenta a escala típica de capacidade de alimentação de biomassa de vários tipos de gaseificadores.

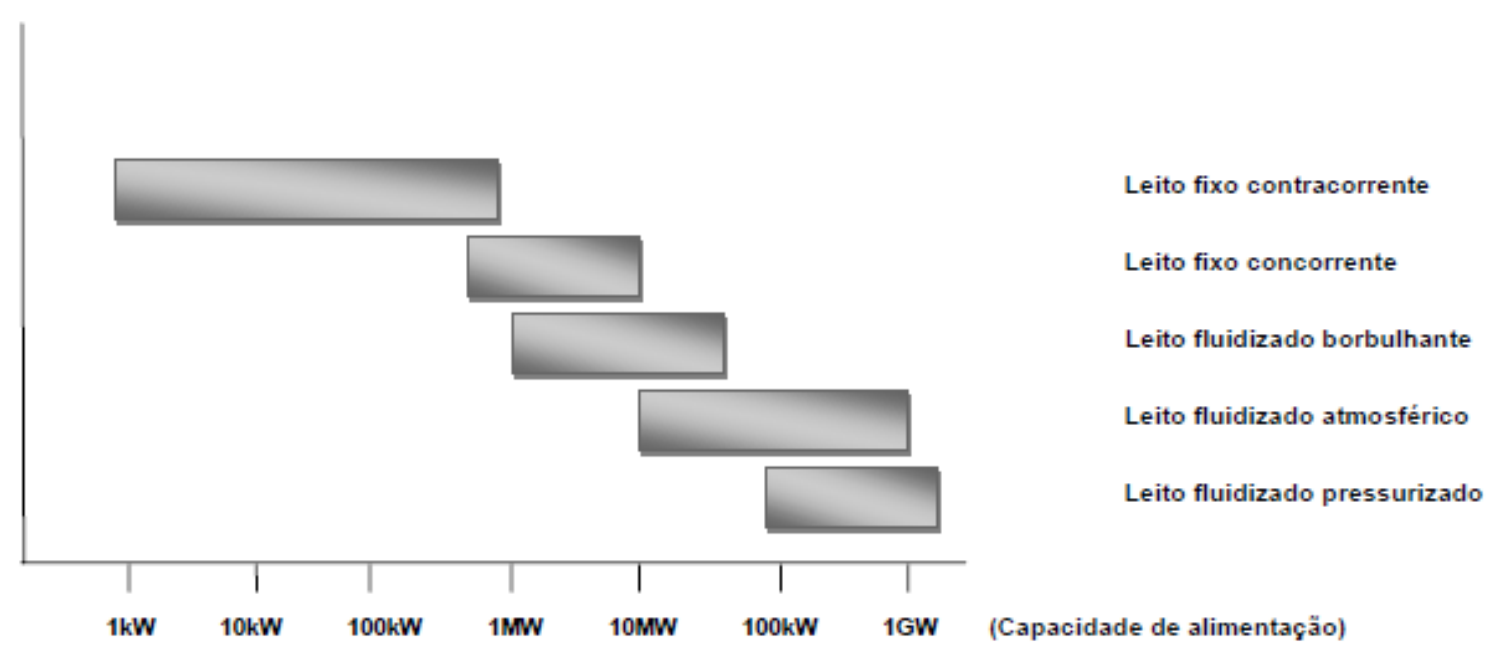

Figura 3.4 - Tipos de gaseificadores e escala típica da capacidade de alimentação (DAURIAT, 2006) 


\section{FUNDAMENTAÇ̃̃O TÉORICA}

\subsubsection{Gaseificadores de Leito Fluidizado}

Nos gaseificadores de leito fluidizado, uma corrente de gás passa no sentido ascendente através de um leito de materiais granulares de fluxo livre, no qual a velocidade do gás é suficientemente alta para que as partículas sólidas sejam separadas entre elas e circulem livremente. Durante toda a circulação no leito, as correntes de gases fluem em um sentido ascendente em canais que contém poucos sólidos, enquanto massas sólidas fluem para baixo (PERRY \& CHILTON, 1973).

$\mathrm{Na}$ gaseificação da biomassa em leito fluidizado, o meio de gaseificação pode ser ar, oxigênio ou vapor, enquanto o leito é geralmente formado por sílica, calcário, dolomita ou alumina (Figura 3.5).

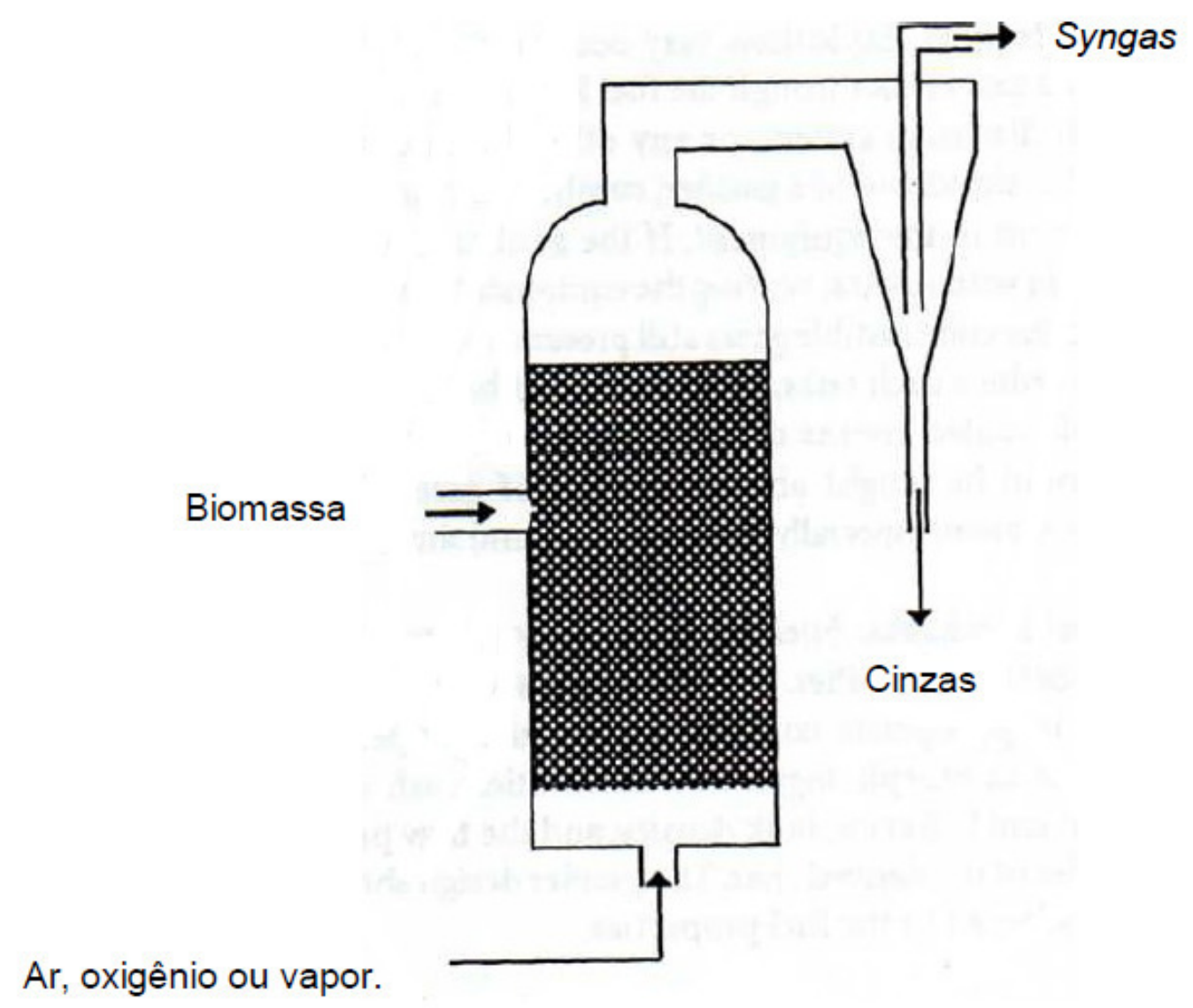

Figura 3.5- Gaseificador de leito fluidizado (FAO, 1986).

Para reter os finos e levá-los de volta ao leito ou, ainda, remover do sistema os finos ricos em cinza, utiliza-se um ciclone. O leito é fluidizado por um tubo de distribuição de gás de aspersão (HANSEN, 1992). A biomassa é inserida por meio 
de um tubo inclinado na parte superior do leito, que é pré-aquecido por meio de um queimador externo e alimentado a gás natural, propano ou óleo combustível.

Os gaseificadores de leito fluidizado oferecem a vantagem de uma alta eficiência de transferência de calor, que resultam em condições muito uniformes no leito. Brown (2005) relata que este tipo de gaseificador é hábil para processar uma vasta variedade de combustíveis e são facilmente reproduzíveis para larga escala de produção. As desvantagens incluem a formação moderada de alcatrão, alta carga de particulados e relativamente um grande consumo de energia para promover a velocidade da corrente de ar.

Em síntese, a gaseificação é endotérmica e requer outras partes simultâneas de queima do combustível ou de uma fonte externa de calor para direcionar o processo. A adição do ar é denominada de gaseificação air-blown e tem a desvantagem de admitir nitrogênio no syngas, que dilui a concentração de compostos reativos e reduz a entalpia química.

A substituição do ar pelo oxigênio, conhecida como gaseificação oxygenblown, elimina o nitrogênio como diluente, porém é uma solução mais expensiva. Diversos pesquisadores têm desenvolvidos métodos para trazer calor suficiente para - gaseificador, em um processo conhecido como gaseificação indireta (BRIGDWATER, 1995). A entalpia química é tipicamente $200 \%$ maior do que a de gaseificadores air-blown.

Apesar de bem estudados, os processos termoquímicos, especificamente a gaseificação, apresentam desafios. Para se tornarem competitivos é necessário que o processo seja flexível o suficiente para abranger a escala de reservas de baixo custo (como por exemplo, resíduos urbanos e agroindustriais) e suas variações nas características químicas e físicas. Turkenburg et.al (2000), por exemplo, indica que a conversão biomassa é uma alternativa preferencial, principalmente quando resíduos de biomassa de baixo custo ou de custo negativo estão disponíveis.

\subsection{Variáveis Econômicas}

O uso da energia da biomassa é notório em vários países. Dentre as barreiras econômicas que dificultam a sua expansão, encontra-se o fato dos vetores energéticos produzidos por sistemas de conversão de biomassa não serem 
competitivos (comparados aos sistemas convencionais), a menos que resíduos da biomassa sejam utilizados.

Os dois setores industriais que oferecem excelentes oportunidades para o uso eficiente deste recurso e de forma competitiva na escala mundial são: a indústria de papel e celulose, bem como a sucroalcooleira. Tradicionalmente, estes setores utilizam os resíduos da biomassa para as suas necessidades internas de energia.

Embora a ausência de regulamentações, visando assegurar tarifas de eletricidade razoáveis, para produtores independentes tenha desfavorecido o investimento das indústrias em uma geração de energia mais eficiente, a liberação dos mercados em muitos países está removendo esta barreira e criando oportunidades para reduzir os custos e modernizar a capacidade de produção.

O uso da biomassa e o emprego de tecnologias dependem das condições locais, tanto físicas quanto socioeconômicas. Turkenburg et. al (2000) ressalta que a otimização de sistemas de geração de energia, por meio do desenvolvimento de sistemas de múltiplas saídas (eletricidade, calor e vetores energéticos) e a produção de biomassa a partir de culturas perenes (tais como a de florestas energéticas), podem conduzir a uma expectativa de custos dos sistemas de conversão da biomassa a valores próximos dos custos da conversão energética do carvão.

Outras questões fortemente relacionadas aos custos são a disponibilidade e a demonstração em larga escala de tecnologias avançadas de conversão, combinando uma alta eficiência operacional e desempenho ambiental com baixo custo de investimento. Para a produção de hidrogênio e metanol, o desenvolvimento de tecnologias de gaseificação, dos mercados e da infraestrutura são considerados fatores determinantes para uma produção avançada de vetores energéticos competitivos.

Não obstante, a conversão da biomassa em vetores energéticos modernos agrega um valor comercial à biomassa, a qual pode propiciar um aumento da geração de renda e desenvolvimento local de economias rurais. Por fim, o custo de sistemas de gaseificação depende, além da qualidade do combustível, dos limites de emissões e impactos considerados aceitáveis. 


\subsection{Impactos Ambientais}

Conforme Bartles et.al (2010), a biomassa pode ser considerada uma fonte energética de carbono "neutro". Isto é, o efeito líquido da concentração do $\mathrm{CO}_{2}$ na atmosfera é considerado zero, uma vez que o dióxido de carbono liberado pela combustão do biocombustível é absorvido pela planta durante a fotossíntese. A substituição de combustíveis fósseis por combustíveis oriundos da biomassa, por meio de tecnologias de conversão eficientes e aceitáveis do ponto de vista ambiental, é uma importante alternativa para reduzir a poluição da atmosfera e a pressão sobre os recursos não renováveis.

Apesar dos benefícios ambientais que podem ser obtidos com o uso da biomassa, se esta não for produzida e empregada de forma sustentável (com políticas adequadas e esquemas de manejo), pode causar significativos impactos adversos, tanto na esfera econômica, como social e ambiental. Estudos recentes têm indicado que o uso da biomassa, a partir de culturas energéticas, pode aumentar as emissões dos gases do efeito estufa (GEE).

Tais indicações têm sido baseadas no uso do solo, da água e de agrotóxicos, mudanças na biodiversidade e na paisagem, principalmente relacionadas ao uso da biomassa oriunda de culturas energéticas (Cf. COUTO \& MULLER, 2008; MACEDO \& LEAL, 2008). Não obstante, a coleta e o transporte de biomassa aumenta a demanda de veículos, combustíveis e infraestrutura, resultando também em um aumento das emissões para a atmosfera.

Desta forma, a conversão da biomassa para produtos intermediários, como os vetores energéticos e outros serviços de energia, deve ir de encontro com os padrões ambientais do local e ainda utilizando, além da biomassa oriunda de resíduos agrícolas e/ou agro-florestais, tecnologias que permitam a limpeza do gás antes da combustão ou, outro posterior processamento, que minimizem os impactos relativos às emissões.

Notadamente, no que se refere ao uso de vetores energéticos produzidos pela conversão da biomassa em energia, a tecnologia $\mathrm{CaC}$ oferece uma solução ideal. Além do alto nível de eficiência (mesmo em aplicações de pequena escala e em carga parcial), sua utilização é favorecida pelos baixos níveis de emissão de 
NOx e CO, comparados ao uso do gás nas turbinas ou motores, e o menor consumo de água em relação às tecnologias concorrentes (FAllJ et. al, 2005).

Turkenburg et. al (2000) ressalta que uma atenção especial deve ser dada a sistemas de conversão da biomassa menores do que $1 \mathrm{MW}_{\text {th. }}$. Embora as tecnologias de limpeza do gás e de posterior utilização, que atendam restritos padrões de emissões, estejam atualmente disponíveis no mercado, os custos dos mesmos podem ter sérios impactos nos custos operacionais e de investimentos de tais sistemas.

Por outro lado, a utilização da biomassa pode oferecer uma série de benefícios ambientais em relação aos combustíveis fósseis que não são aparentes no custo (externalidades). Além de ser reconhecida como uma fonte de carbono neutro, a biomassa apresenta baixo conteúdo de enxofre e encontra-se disponível mundialmente, enquanto os combustíveis fósseis estão concentrados em determinadas regiões e precisam ser importados pela maioria dos países.

Particularmente no Brasil, o Programa Nacional de Álcool, por exemplo, gerou e gera positivos impactos ambientais e econômicos na redução de emissões de carbono e da importação de petróleo. Em suma, as tecnologias de gaseificação da biomassa apresentam vantagens e desvantagens em relação aos aspectos ambientais e econômicos, tanto no que diz respeito ao recurso, quando ao método de conversão, tal como a energia solar fotovoltaica, apresentada no capítulo a seguir. 


\section{ENERGIA SOLAR FOTOVOLTAICA}

A conversão de energia solar fotovoltaica (FV) é a conversão direta da irradiação solar em eletricidade, por meio de células solares (Figura 4.1). Embora o primeiro dispositivo tenha sido demonstrado em 1839 por Edmond Bequerel, a compreensão e a exploração do sistema dependeram de importantes avanços científicos e tecnológicos ocorridos no século 20.

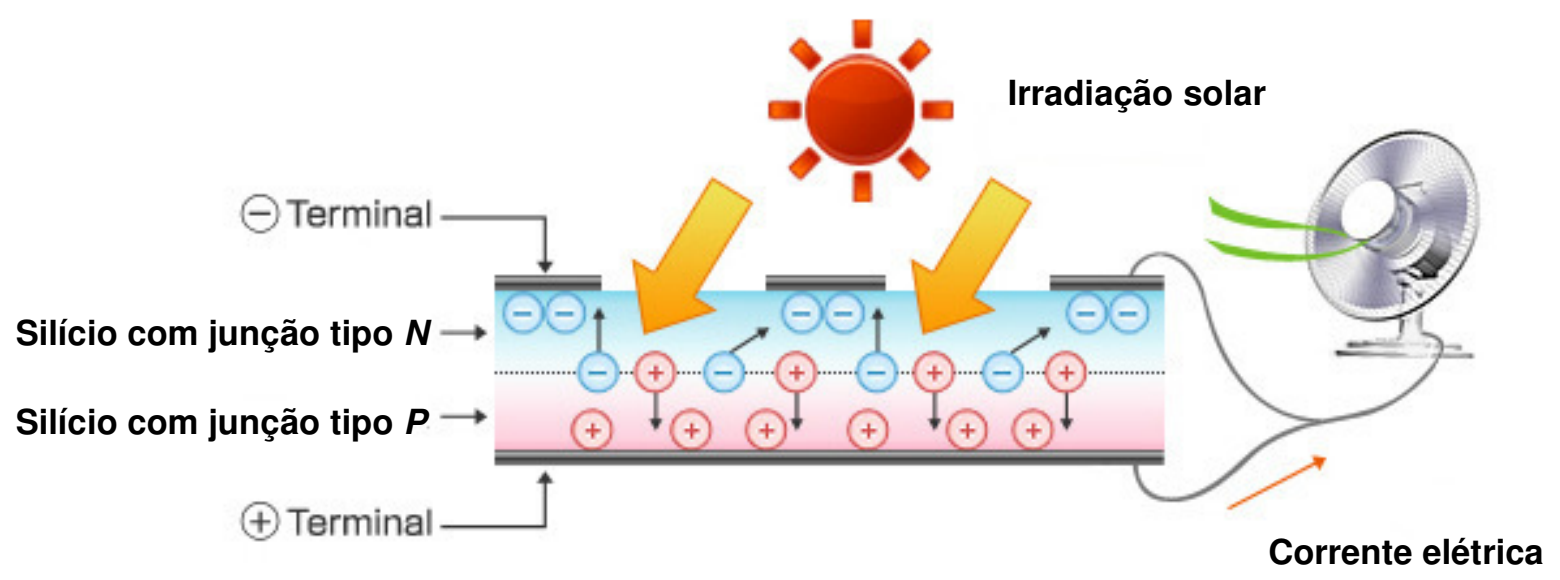

Figura 4.1 - Conversão da energia solar em eletricidade por meio de células solares fotovoltaicas (adaptado a partir de Sumco Corporation, 2010). ${ }^{1}$

Segundo Wenham et. al (2009), dentre estes progressos, destaca-se o desenvolvimento da mecânica quântica, uma das maiores conquistas intelectuais do século 20. Não obstante, o desenvolvimento de semicondutores (condicionado aos avanços obtidos anteriormente pela academia) influenciou a revolução da indústria eletrônica e fotônica, introduzindo novos caminhos tecnológicos ${ }^{2}$.

Neste sentido, a importância da energia solar fotovoltaica no mundo tem crescido significativamente nos últimos anos, não apenas diante dos avanços tecnológicos e o aumento da participação da energia solar no mercado energético, como também em virtude da necessidade de implementação de fontes de energia renováveis na matriz energética de muitos países.

\footnotetext{
${ }^{1}$ Disponível em http://www.sumco.com. Acessado em fevereiro de 2010.

2 O desenvolvimento da tecnologia fotovoltaica moderna pode ser consultado em Loferki (1993) e a história dos primeiros estudos, com riqueza de detalhes técnicos, na publicação de Crossley et. al (1968).
} 
Nomeadamente, o aumento do uso de sistemas fotovoltaicos ocorreu principalmente na Europa, onde a Espanha e a Alemanha constituem importantes exemplos. Novas centrais de conversão de energia elétrica fotovoltaica são instaladas anualmente em diversas regiões do mundo, com potências tipicamente superiores a 1MW (BURLER et. al, 2010).

\subsection{Recurso e Potencial Energético}

Comumente, a fonte de energia solar é descrita em termos de insolação, ou seja, de energia disponível por unidade de área e por unidade de tempo $\left(\mathrm{kWh} / \mathrm{m}^{2}\right)$. Para estimar o potencial de produção energética deste recurso em uma região, utilizase 0 índice de insolação que é uma média da radiação solar que atinge uma determinada área. A radiação solar está disponível em qualquer local na superfície terrestre e a irradiância máxima (densidade de potência) de luz solar na Terra é de cerca de $1000 \mathrm{~W} / \mathrm{m}^{2}$, independentemente da localização (TURKENBURG, 2000).

Medida no plano horizontal, a radiação solar varia ao longo da superfície da Terra por um fator de 3 . Isto é, cerca de $800 \mathrm{kWh} / \mathrm{m}^{2} /$ ano no norte da Escandinávia e do Canadá a um máximo de $2500 \mathrm{kWh} / \mathrm{m}^{2} / a n o$ em algumas áreas desérticas. As diferenças das médias mensais de irradiação, entre junho a dezembro, por exemplo, pode variar de $25 \%$ (próximos ao equador) até um fator de $10 \mathrm{em}$ áreas muito próximas ao norte ou ao sul, determinando desta forma o padrão anual de produção de sistemas de energia solar (TURKENBURG, 2000).

Embora a radiação na superfície do sol seja razoavelmente constante (WENHAM et. al , 2009), o número de vezes que esta alcança à superfície da terra é altamente variável devido à absorção e reflexão dos raios solares na atmosfera terrestre. Ou seja, a luz solar que atravessa a atmosfera é atenuada (ou reduzida), em cerca de 30 vezes decorrente da reflexão por aerossóis e partículas de poeira e/ou absorção por gases da atmosfera, tais como oxigênio, ozônio, vapor de água e dióxido de carbono. Soma-se, ainda, a cobertura de nuvens, que é definitivamente responsável por uma significativa atenuação ou reflexão da irradiação ${ }^{3}$.

Comumente, considera-se a irradiação solar em dois tipos: i) direta (beam), caracterizada pela irradiação direta do sol e ii) difusa, caracterizada pela irradiação de

\footnotetext{
${ }^{3}$ A presença de nuvens tipo cumulus e a baixa altitude das mesmas são efetivas no bloqueio dos raios solares.
} 


\section{FUNDAMENTAÇÃO TÉORICA}

advinda de qualquer lugar do céu. A somatória dos dois tipos de irradiação (direta e difusa) é denominada irradiação global. A figura 4.2 apresenta como a reflexão atmosférica resulta na componente difusa da irradiação solar chegando a partir de todas as direções do céu.

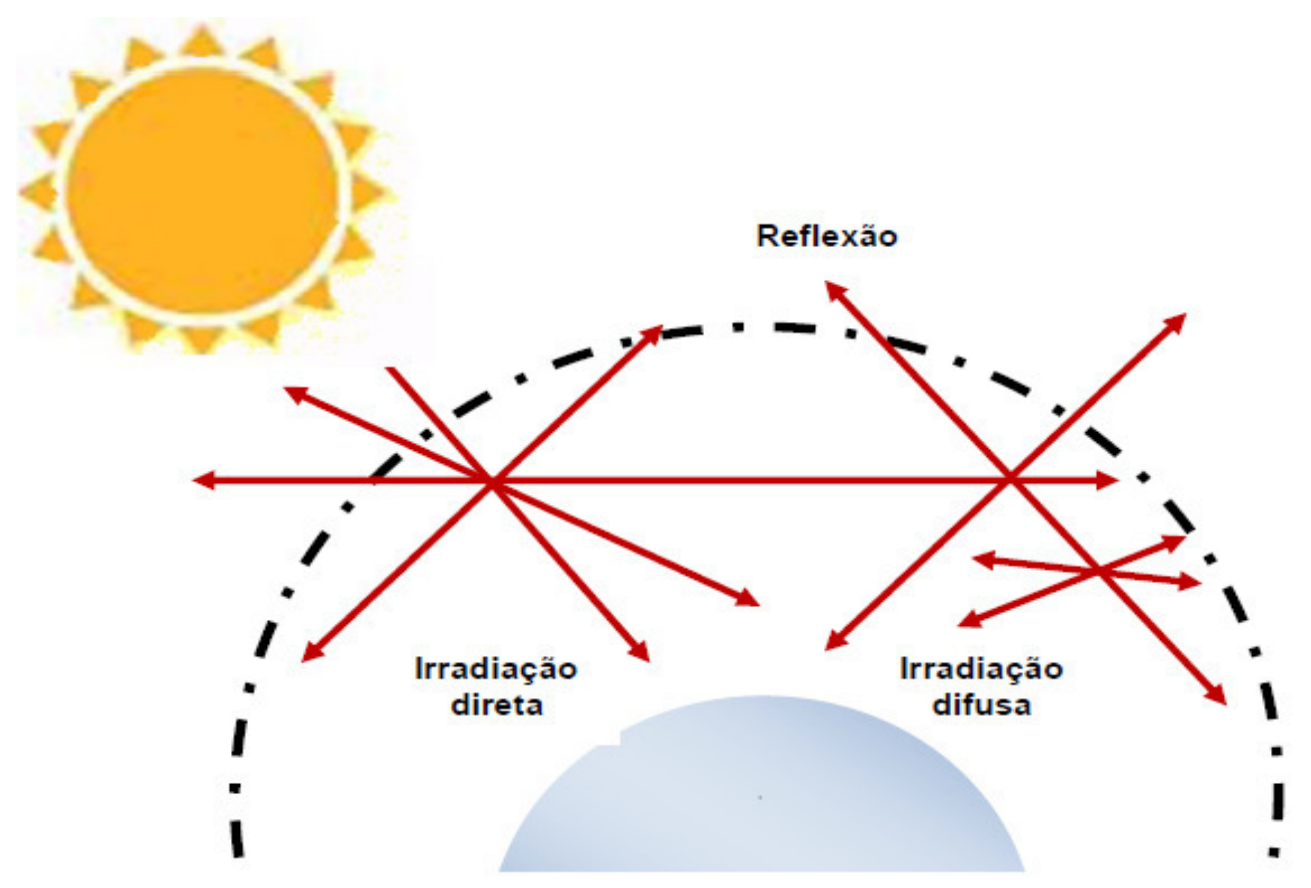

Figura 4.2 - Reflexão da radiação solar na atmosfera conduzindo a irradiação difusa (baseado em WENHAM et. al , 2009).

A proporção difusa do total de irradiação anual pode variar de $10 \%$ em áreas ensolaradas até acima de $60 \%$ em áreas com clima moderado, como por exemplo, a Europa Ocidental. A proporção real entre a irradiação difusa e a direta determina, em grande parte, o tipo de tecnologia de energia solar (fotovoltaica ou de concentração) que pode ser utilizada em um dado local (TURKENBURG, 2000).

Para projetar os sistemas fotovoltaicos, as estimativas esperadas de incidência de insolação na superfície de uma dada região são essenciais e, na maioria das aplicações, os valores da média diária de insolação no mês são suficientes. Usualmente, a separação dos componentes de irradiação (difusa e direta) é requerida para estimar os efeitos do ângulo do módulo. Revisões abrangentes sobre os dados e as estimativas de insolação podem ser encontradas em Perez et. al., (2001) e Lorenzo (2003).

Particularmente, o Brasil apresenta um alto índice de insolação, com quase todas as suas regiões recebendo anualmente mais de $1900 \mathrm{kWh} / \mathrm{m}^{2}$. A energia solar 
incidente sobre o solo brasileiro ( 15 trilhões de MWh/ano) corresponde a 20.000 vezes a sua produção anual de petróleo ou 50.000 vezes o consumo nacional de energia elétrica (PINHEIRO, 2010).

Segundo Martins et. al (2008), o total em 1 (um) ano de irradiação solar global diária em qualquer região do Brasil (1500 a $2500 \mathrm{kWh} / \mathrm{m}^{2}$ ) é maior do que a maioria dos países europeus como a Alemanha (900 a $1250 \mathrm{kWh} / \mathrm{m}^{2}$ ), França (900 a 1650 $\mathrm{kWh} / \mathrm{m}^{2}$ ) e Espanha (1200 a $1850 \mathrm{kWh} / \mathrm{m}^{2}$ ), onde projetos de utilização dos recursos da energia solar são bastante disseminados, alguns com grandes incentivos governamentais. A figura 4.3 apresenta a irradiação global horizontal no Brasil (média anual).

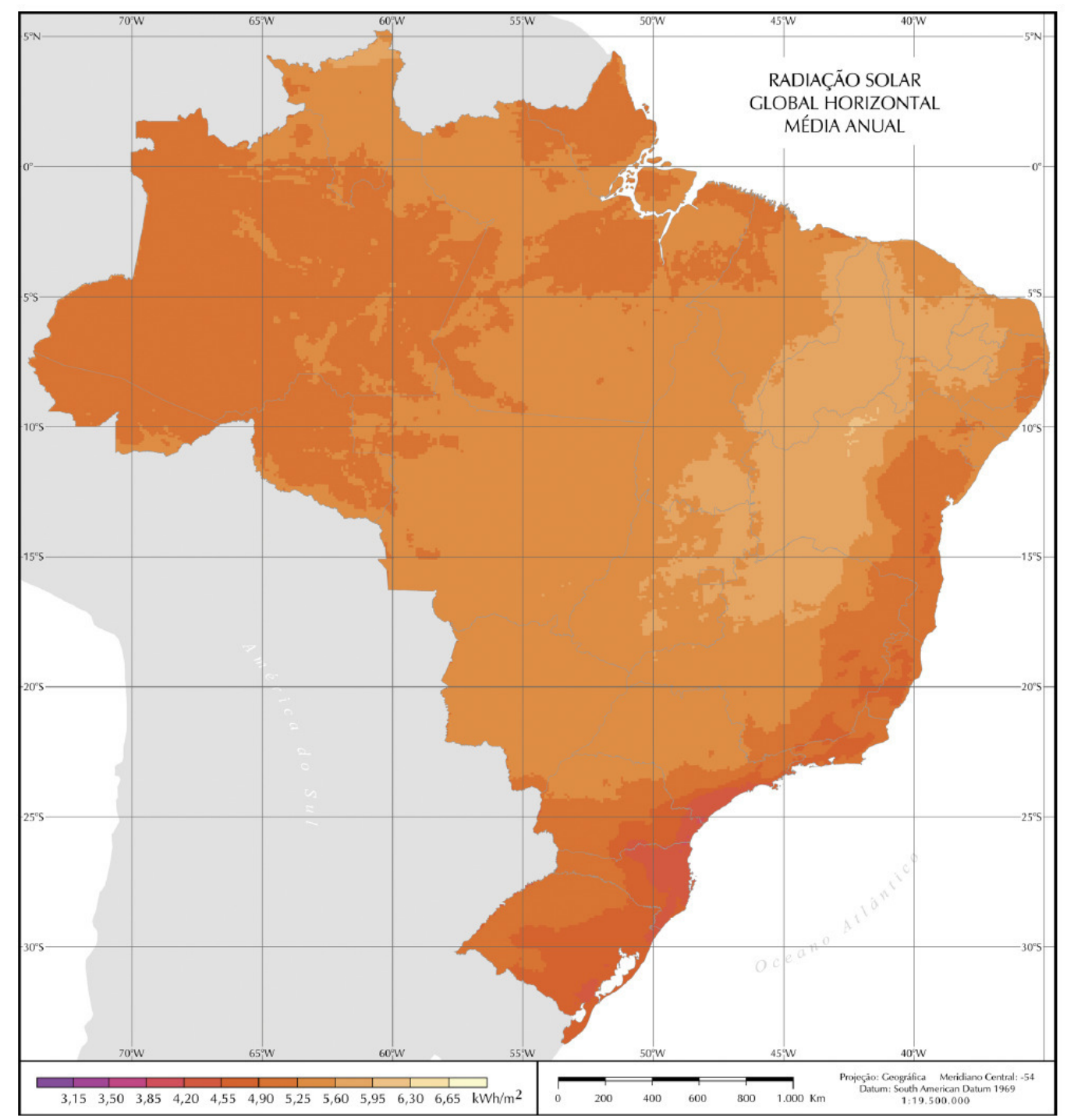

Figura 4.3 - Média anual da irradiação global horizontal no Brasil (Pereira et. al , 2006). 
Os valores de maior irradiação solar no Brasil são encontrados na área semiárida da região nordeste, no qual o ambiente extremamente seco (semidesértico) e o alto número de horas de sol por ano resultam em uma média de irradiação solar de $6,5 \mathrm{kWh} / \mathrm{m}^{2} / \mathrm{dia}$. Pequenas diferenças podem ser encontradas na região sudeste durante a primavera e o verão. Entretanto, a irradiação solar nesta região brasileira apresenta alta variabilidade ao longo do ano devido à incursão de frentes frias, originadas na região da Antártica, principalmente durante o outono e o inverno (MARTINS et. al , 2008).

Informações detalhadas da insolação no Brasil, incluindo a metodologia de obtenção e análise dos dados, bem como cenários descritivos da utilização dos recursos de energia solar podem ser consultados no Atlas Brasileiro de Energia Solar, elaborado por Pereira e colaboradores (2006).

Em relação ao uso da energia fotovoltaica, a eficiência líquida de sistemas de conversão solar em energia elétrica é tipicamente 10 a $15 \%$. Desta forma, são necessárias áreas substanciais para capturar e converter parte significativa da energia solar para atender as necessidades de energia, especialmente nos países industrializados, em função do atual consumo de energia. Para uma eficiência da planta de $10 \%$ é necessário, por exemplo, uma área de 3 a $10 \mathrm{~km}^{2}$ para gerar uma média de $100 \mathrm{MW}$ de eletricidade (ou 0,9 TWh de eletricidade ou 3,2 PJ de eletricidade por ano) utilizando um sistema fotovoltaico ou a eletricidade solar térmica (TURKENBURG, 2000).

A potência total média disponível na superfície da Terra sob a forma de irradiação solar é superior ao consumo total de energia humana em cerca de 1500. A potência média solar disponível, calculado por pessoa, é de $3 \mathrm{MW}$, enquanto 0 consumo varia de $100 \mathrm{~W}$ (países menos industrializados) para $10 \mathrm{~kW}$ (EUA), com uma média de $2 \mathrm{~kW}$ (TURKENBURG, 2000).

Embora esses números forneçam uma imagem útil aproximada dos limites absolutos da possibilidade de uso energia solar, estes têm pouco significado em relação ao potencial técnico e econômico. Devido às diferenças no padrão de fornecimento de energia solar, a infraestrutura de energia, a densidade populacional, as condições geográficas, entre outros, trona-se necessário uma análise detalhada 
técnica e econômica da energia solar regionalmente ou nacionalmente. O potencial global é a soma dos potenciais regionais e nacionais (TURKENBURG, 2000).

O potencial econômico da energia solar é uma questão de debate e depende das perspectivas de redução de custos. No passado recente, um cenário elaborado a partir de vários estudos avaliou o potencial de contribuição das tecnologias de energia solar (IIASA e WEC, 1998; WEC, 1994 a; Johansson e outros 1993a; Shell, 1996; Greenpeace e SEl, 1993), fornecendo um panorama dos diferentes pontos de vista sobre a penetração da energia solar no século 21 (tabela 4.1).

Tabela 4.1 - Potencial de contribuição das tecnologias de energia solar (Turkenburg et. al, 2000).

\begin{tabular}{lccc}
\hline \multicolumn{1}{c}{ Estudo } & $\begin{array}{c}2020-2025 \\
\left(10^{18} \mathrm{kWh}\right)\end{array}$ & $\begin{array}{c}2050 \\
\left(10^{18} \mathrm{kWh}\right)\end{array}$ & $\begin{array}{c}2100 \\
\left(10^{18} \mathrm{kWh}\right)\end{array}$ \\
WEC, 1994 a,b & 16 & & \\
IASA e WEC, 1998 & $2-4$ & $7-14$ & \\
RIGES, 1993 (solar e eólica) & 17 & 35 & 830 \\
Shell, 1996 & $<10$ & 200 & \\
Greenpeace e SEl, 1993 (solar e eólica) & 90 & 270 & \\
Total de energia consumida no mundo & $400-600$ & $400-1200$ & \\
\hline
\end{tabular}

No que se refere ao potencial técnico de energia fotovoltaica, este tem sido estudado com certo detalhe em vários países. Em países densamente povoados, com uma infraestrutura bem desenvolvida, há uma ênfase nas aplicações do sistema fotovoltaico conectadas à rede no ambiente construído (incluindo integrado a elementos de infraestrutura).

Tais sistemas são, necessariamente, pequenos ou de médio porte, normalmente de $1 \mathrm{~kW}$ a $1 \mathrm{MW}$. A eletricidade é fisicamente gerada perto do lugar onde a eletricidade também é consumida, nos países com áreas menos densamente povoadas também há um considerável interesse em sistemas terrestres, geralmente maior que $1 \mathrm{MW}$.

A área necessária para gerar uma potência elétrica média igual ao consumo humano total de energia- assumindo $10 \%$ da eficiência da planta e insolação de 2.000 $\mathrm{kWh} / \mathrm{m}^{2} /$ ano - é de aproximadamente $750 \mathrm{~km}^{2}$. Nos países ou regiões rurais, com 
uma infraestrutura de rede frágil ou incompleta, sistemas autônomos pequenos e sistemas modulares elétricos podem ser utilizados para a eletrificação de casas e comunidades rurais (TURKENBURG, 2000).

Segundo Katan e colaboradores (2009), a eletricidade a partir sistemas FV distribuídos é, ainda hoje, mais onerosa do que a eletricidade obtida a partir de sistemas convencionais. Consequentemente, sistemas distribuídos de energia solar FV não são economicamente viáveis, na maioria dos mercados, sem um suporte governamental. Desta forma, o foco das políticas públicas, principalmente na Europa, Ásia e América do Norte, é o de providenciar incentivos suficientes para assegurar a eletricidade solar a um custo adequado ás condições locais.

\subsection{Características do Sistema Fotovoltaico}

Conforme Reis e colaboradores (2005) existem na natureza materiais classificados como semicondutores que se caracterizam por possuírem uma banda de valência totalmente preenchida por elétrons e uma banda de condução totalmente vazia a temperaturas muito baixas. Tais materiais apresentam a característica de excitação térmica de portadores da banda de valência para a banda de condução.

No caso das células fotovoltaicas, a propriedade fundamental do material semicondutor é a possibilidade de fótons (na faixa do visível), com energia superior ao gap do material, excitarem elétrons à banda de condução. Este efeito, que pode ser observado em semicondutores puros, também caracterizados como intrínsecos, não garante por si só o funcionamento de células fotovoltaicas. Para obtê-las, é necessária uma estrutura apropriada para que os elétrons excitados possam ser coletados, gerando uma corrente útil (KOMP, 2002).

Neste sentido, acrescenta-se aos átomos de silício, átomos de fósforo e boro, num processo conhecido como dopagem do silício, formando uma junção $p n$. Quando uma junção pn fica exposta a fótons com energia maior que o gap existente entre a banda de valência e condução, ocorre a geração de pares elétrons-lacuna. Se esses elétrons ocorrem na região onde o campo elétrico é diferente de zero, as cargas serão aceleradas produzindo, desta forma, uma corrente através da junção; este deslocamento de cargas origina uma diferença de potencial no qual chamamos de efeito fotovoltaico (WENHAM et. al, 2007) (Figura 4.4). 


\section{FUNDAMENTAÇÃO TÉORICA}

Para fazer uso da eletricidade produzida nas células e módulos fotovoltaicos, o sistema é constituído por peças eletrônicas (inversores, transformadores), estruturas de apoio (suporte de alumínio, blocos de concreto), e por vezes de meios de armazenamento de eletricidade (baterias). Comumente utiliza-se o termo Balance of System (BOS) para designar o conjunto de componentes necessários para o funcionamento e instalação do sistema, excluindo os módulos e/ou painéis.
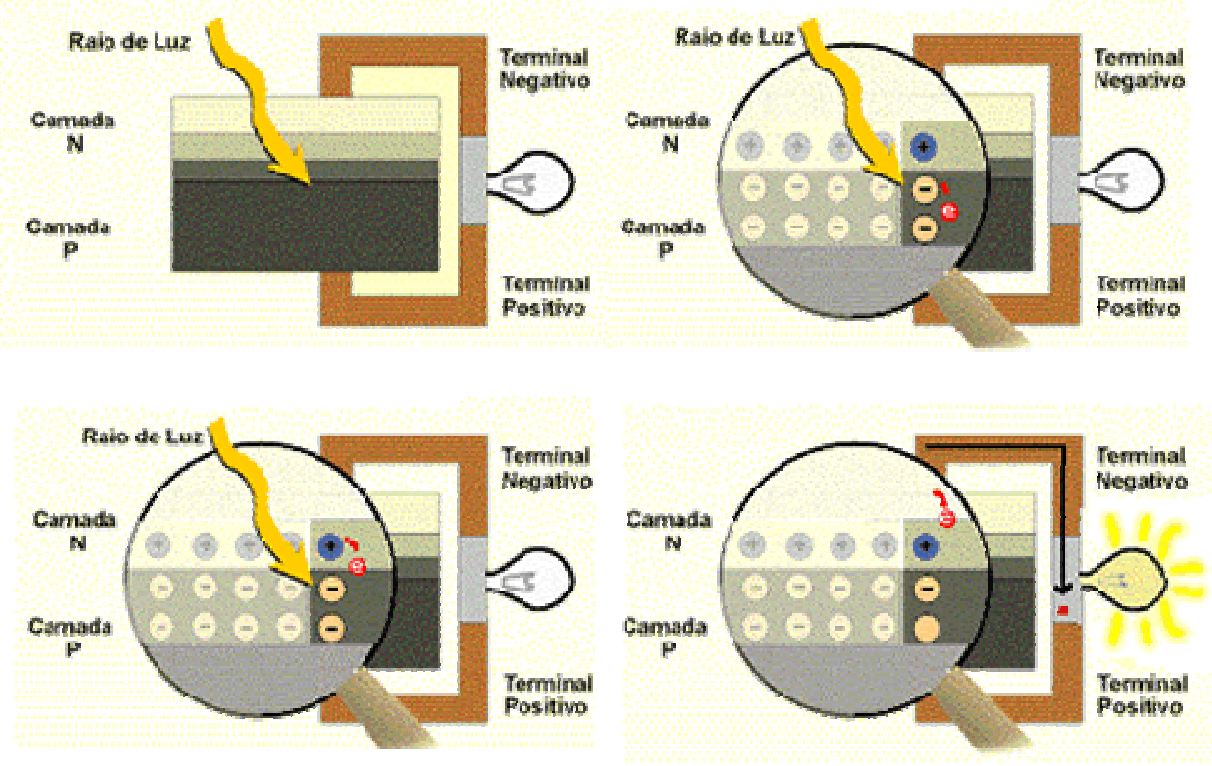

Figura 4.4 - Efeito fotovoltaico na junção pn (Eletrosul, 2010) ${ }^{4}$.

Tendo em vista que o componente fundamental dos sistemas de energia solar fotovoltaica é o módulo solar (comumente constituído de um número de células solares ligadas em série), os sistemas FV também podem ser classificados em relação ao tipo de módulo empregado.

\subsubsection{Tecnologias de Conversão}

Os módulos com células solares baseadas em silício cristalino (Si-c) são considerados a tecnologia mais tradicional e madura. $\mathrm{O}$ conhecimento da tecnologia que emprega o silício (em particular, o monocristal) e a abundância deste recurso na natureza são as razões mais importantes que tornaram o silício o material predominante no processo de desenvolvimento tecnológico. Um diagrama de blocos das tecnologias atualmente disponíveis é ilustrado na figura 4.5.

\footnotetext{
${ }^{4}$ Disponível em http://www.eletrosul.gov.br. Acessado em fevereiro de 2010.
} 
O problema da eficiência de conversão e custo do material, e ainda o grande conhecimento adquirido pela teoria física das células, tem impulsionado a pesquisa de células solares produzidas com materiais diferentes do silício monocristalino (Si-sc). Atualmente, são estudados as tecnologias de células solares baseadas em silício multicristalino (Si-mc) e amorfo (Si-a), o cádmio telúrio (CdTe) e o cobre índio diselênio (CIS), dentre outros.

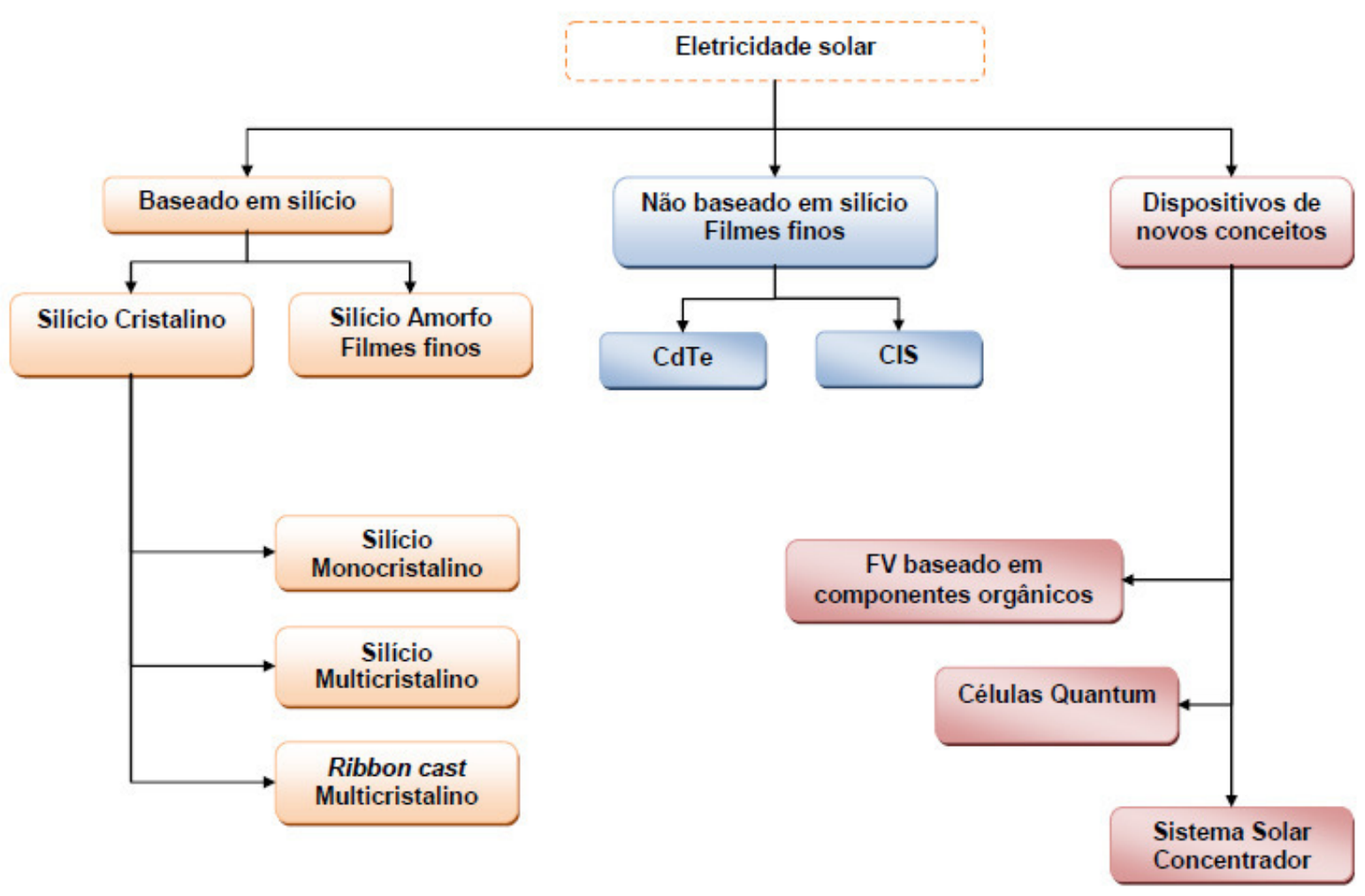

Figura 4.5 - Diagrama das atuais tecnologias de energia solar fotovoltaica disponíveis (adaptado a partir de Raugei \& Frankl , 2009).

Destaca-se que, recentemente, um tipo de módulo inovador baseado em $\mathrm{Si}$ cristalino, denominado tecnologia de silício ribbon, foi introduzido no mercado. Esta tecnologia utiliza o silício disponível mais eficientemente, pois as lâminas são produzidas (cristalizadas) a partir do silício fundido. Tal prática reduz o consumo de energia, de demanda de tempo e de perdas de materiais e consequentemente, conduz a custos mais baixos de produção.

Os módulos de silício amorfo são produzidos a partir de uma camada fina de silício hidrogenado depositado em vidro, caracterizando-se essencialmente por uma baixa eficiência e baixo custo. Os módulos são primariamente empregados integrados a edificações (fachadas, entre outros), bem como em bens de consumo eletrônicos. 
Já os módulos FV não baseados em silício (CIS e CdTe) são fabricados utilizando camadas extremamente finas (poucos mícrons) de semicondutores binários eletrodepositados em painéis de vidro. Estas tecnologias são comparativamente novas e alcançaram o mercado no início de 2000.

De acordo com Raugei e Frankl (2009), sob o título de dispositivos de novo conceito, três grandes famílias de tecnologias são agrupadas:

i. Módulos de eficiência baixo-média, baseados em orgânicos (por exemplo, polímeros orgânicos) de custo ultra-baixo,

ii. Módulos de eficiência ultra-alta, baseados em células quantum e dispositivos nanoestruturados;

iii. Sistemas solares concentradores, no qual o arranjo fotovoltaico é montado em grandes estruturas móveis (rastreadores) que dirigem o módulo continuamente em direção ao sol.

Todas as tecnologias da terceira geração estão ainda no estágio de protótipos e não possuem participação no mercado, com exceção dos sistemas solares concentradores (RAUGEI \& FRANKL, 2009).

\subsubsection{Tamanhos de Instalação e Tipos de Aplicações}

A energia fotovoltaica pode ser usada em uma ampla variedade de aplicações, desde produtos de consumo e pequenas unidades autônomas de uso rural (como sistemas de energia solar residencial e lanternas solares) aos sistemas de cobertura conectados à rede e centrais de grande porte. O tamanho típico do sistema varia de $50 \mathrm{~W}$ a $1 \mathrm{~kW}$ para sistemas autônomos com armazenamento em bateria, de $500 \mathrm{~W}$ a $5 \mathrm{~kW}$ para os sistemas de cobertura conectados à rede, e de $10 \mathrm{~kW}$ a vários MW para sistemas terrestres ligados a rede e grandes sistemas integrados em prédios.

Dentre os segmentos do mercado, espera-se o rápido crescimento para a aplicação em áreas rurais e a construção de sistemas integrados (como precursores da aplicação em larga escala.) devido aos esforços conjuntos dos segmentos de marketing e incentivos financeiros (RAUGEI \& FRANKL, 2009).

Considerando a capacidade instalada na Europa, Japão, China, Taiwan e Estados Unidos (o maior mercado de energia fotovoltaica do mundo), quatro tipos de 
instalações de sistemas fotovoltaicos são as aplicações predominantemente encontradas, a sabe (IEA/PVSP, 2009):

i. Grandes plantas de geração elétrica - centralizadas e conectadas à rede de distribuição; (on grid) (Figura 4.6);

ii. Pequenos sistemas em telhados e fachadas - distribuídas e conectadas a rede de distribuição (on grid) (Figura 4.7 e 4.8);

iii. Plantas de geração e instalações industriais em áreas remotas - não conectadas a rede (off grid) (Figura 4.9);

iv. Sistemas autônomos em telhados para residências em áreas remotas não conectadas a rede e doméstica (off grid) (Figura 4.10).

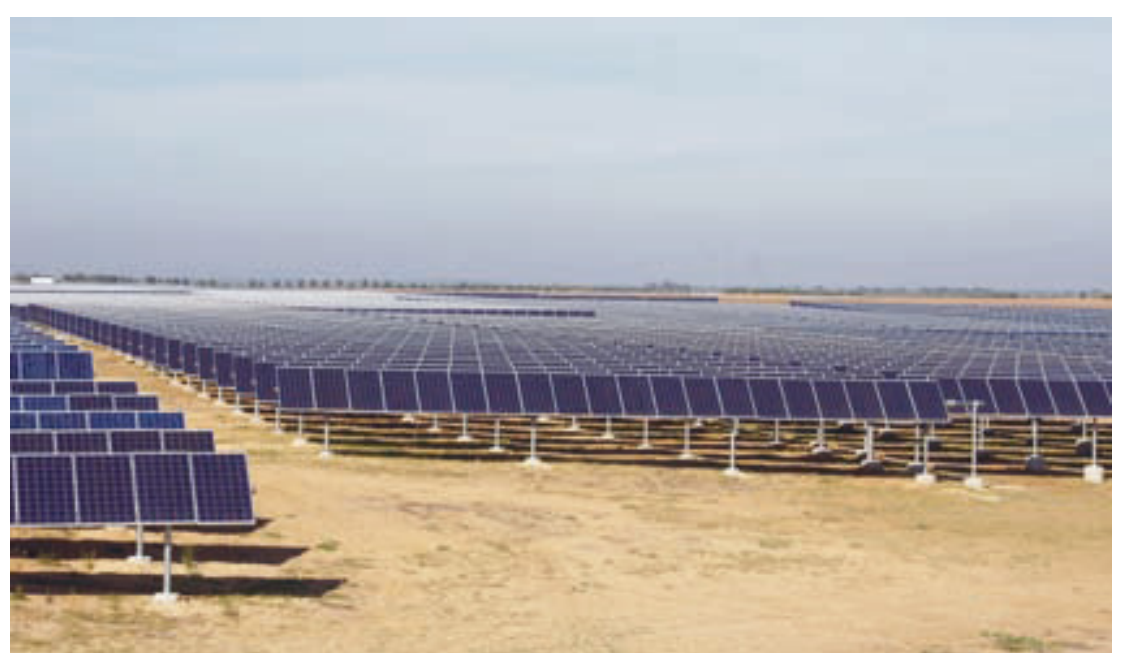

Figura 4.6 - Planta Solar Fotovoltaica de10 MWp, on grid (IEA/PVSP, 2009)

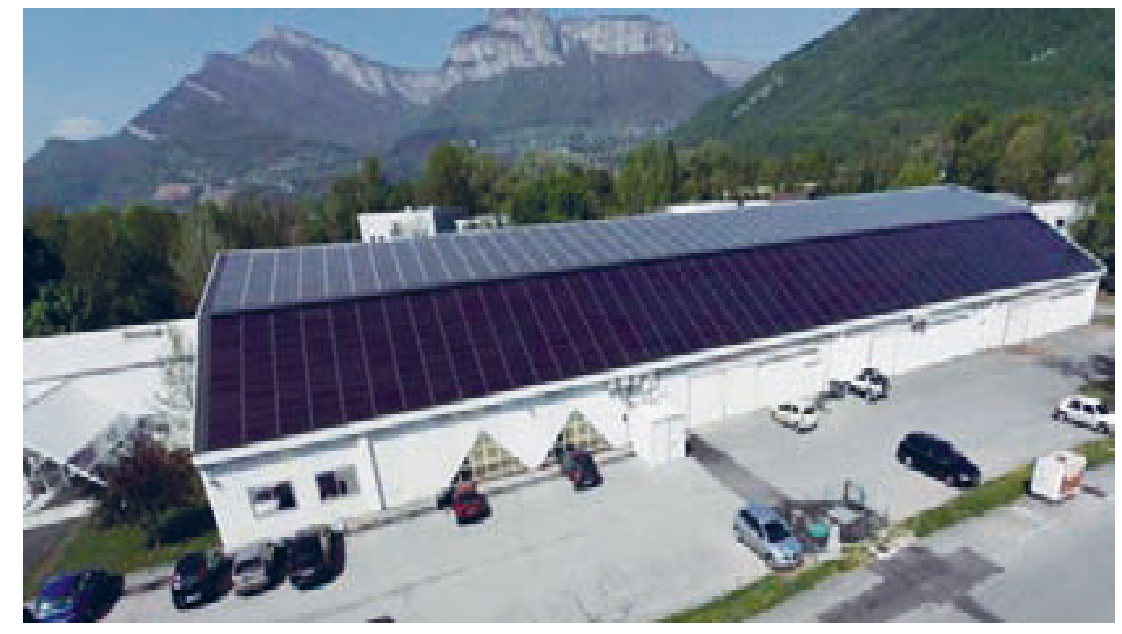

Figura 4.7 - Sistema Solar Fotovoltaico de 203 kWp, tipo telhado (IEA/PVSP, 2009) 


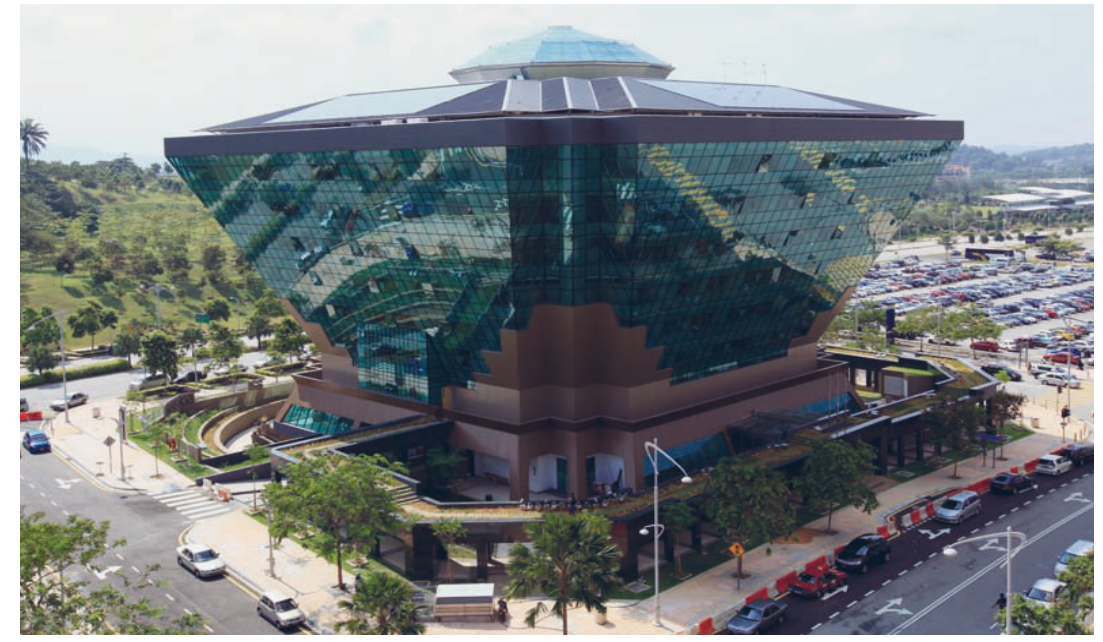

Figura 4.8 - Sistema Solar Fotovoltaico de 71,5 kWp, tipo fachada (IEA/PVSP, 2009)

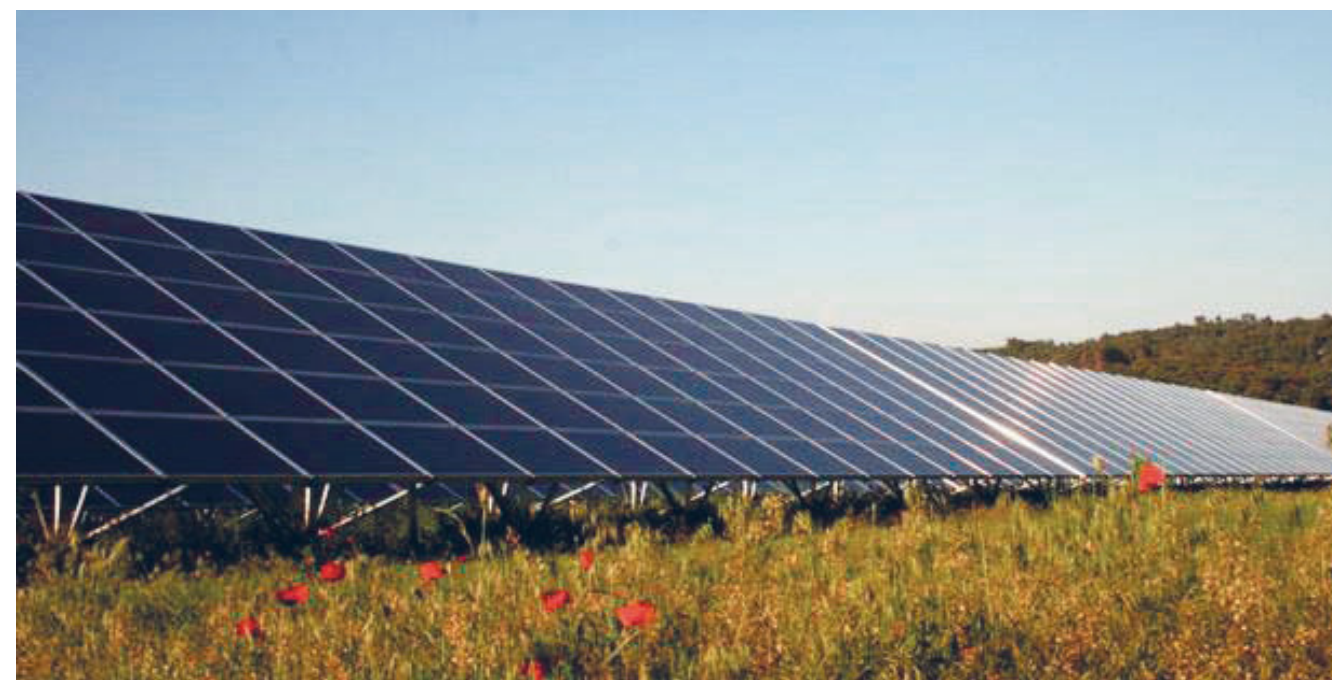

Figura 4.9 - Planta Solar Fotovoltaico de 4,2 MW, off grid (IEA/PVSP, 2009).

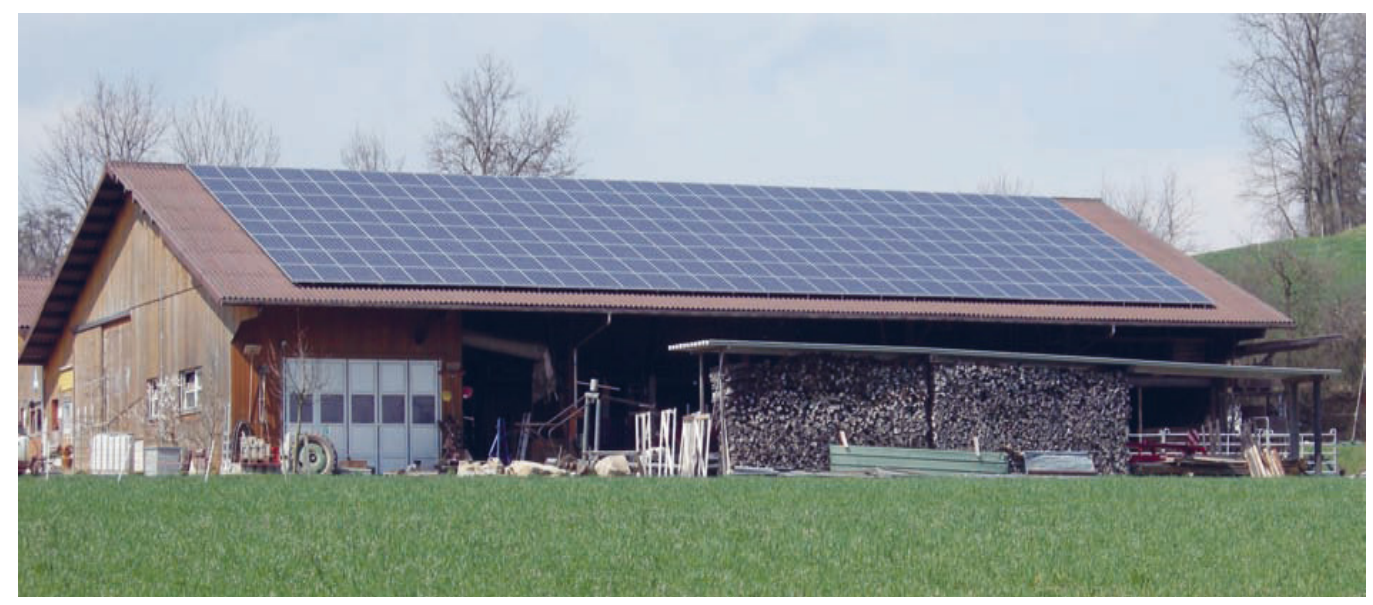

Figura 4.10 - Sistema Solar Fotovoltaico autônomo, off grid, tipo telhado (IEA/PVSP, 2009). 
Conforme Raugei e Frankl (2009), estes quatro tipos de instalação diferem significativamente nos requerimentos para os componentes do BOS e, neste caso, o principal aspecto de distinção é a necessidade de baterias para o armazenamento de energia em sistemas não conectados à rede.

Como os módulos fotovoltaicos oferecem uma fonte de energia intermitente, a maioria dos sistemas autônomos é equipada com bateria de armazenamento (geralmente uma bateria de chumbo-ácido) para fornecer energia durante a noite ou durante dias quando a luz solar é insuficiente.

Em alguns casos, as baterias armazenam energia durante períodos mais longos. Ao utilizar sistemas fotovoltaicos ligados em rede, esta serve como "depósito virtual", o que significa que a eletricidade fornecida pela rede de energia fotovoltaica pode efetivamente reduzir o uso de combustível por usinas de energia alimentadas com carvão, petróleo ou gás.

\subsection{Variáveis econômicas}

Ainda que os custos reais de todos os componentes de um sistema FV variem largamente e dependa de diversas especificações técnicas, tais como, tipo de tecnologia, tamanho do sistema e conexão com a rede de distribuição até a finalidade do uso, o custo do módulo tipicamente representa cerca de $40 \%$ a $60 \%$ do custo total de um sistema FV completo, ou seja, o módulo é um elemento chave no preço final do sistema FV instalado (IEA - PVPS, 2009).

De acordo com a Administração de Informação em Energia - Energy Information Administration (EIA), o custo dos módulos de FV vem declinando significativamente, de mais de USD100 Mp em 1979 para menos de USD 6/Wp nos dias atuais. Reduções drásticas e recentes do custo de produção tem pavimentado um caminho para as tecnologias FV se tornarem mais competitivas em relação à geração de energia baseada em combustível fóssil (FTENASKIS et. al., 2009). Primariamente, a redução do custo das tecnologias FV resultou no incremento da eficiência das células, inovações no processo de manufatura do módulo e do aumento da manufatura em escala.

O aumento da eficiência das tecnologias de energia solar decorreu de uma série de avanços tecnológicos. Por exemplo, a texturização da superfície da célula e o 
uso de cobertura anti-reflexo propiciaram um acréscimo da absorção da luz, enquanto o isolamento das bordas de junção e aplicação da impressão de camadas de alumínio na parte posterior da superfície de contato da célula (formando uma região altamente dopada) permitiu uma melhor separação e captura da carga de elétrons (Wenham et. al, 2007).

Tais práticas conduziram a significativas melhorias na saída da densidade de potência e também resultaram, juntamente com a modernização dos processos de produção de lingotes e lâminas, na redução do uso e desperdício de silício de alta pureza (Sinke, 2005). Em função da economia de escala de manufatura, durante a última década a indústria de energia solar cresceu anualmente cerca de $30 \%$ (OCDE/IEA, 2003). Programas de suporte governamentais e incentivos econômicos conduziram a uma elevação nos níveis de produção e vendas de células e módulos solares.

O total do volume de produção reportado pelos países participantes do Programa de Sistemas de Energia Fotovoltaicos - Photovoltaics Power Systems Program (PVSP) apresentou um aumento de 56\%, de 2400 MW em 2007, para 3740 MW em 2008. Os Estados Unidos (EUA), o terceiro maior país produtor de células, alcançou um percentual de aumento de $67 \%$ para o mesmo período (IEA- PVPS, 2009).

Em anos recentes, uma ligeira mudança no mercado de FV provocou um aumento dos custos e dos preços devido à diminuição da reserva de silício de alta pureza. Isto ocorreu como consequência do rápido crescimento do mercado global de FV nos últimos cinco anos e paralelo a demanda crescente da atividade da indústria de semicondutores, no qual a indústria FV compete por silício (policristalino virgem).

Sob outro aspecto, a falta de silício estimulou fortemente o desenvolvimento de tecnologias de filmes finos, as quais são menos dependentes deste semicondutor e apresentam um menor uso de energia e custo na manufatura do que as tecnologias de Si-c. A divisão do mercado para as diferentes tecnologias de FV é apresentado na figura 4.11 . 


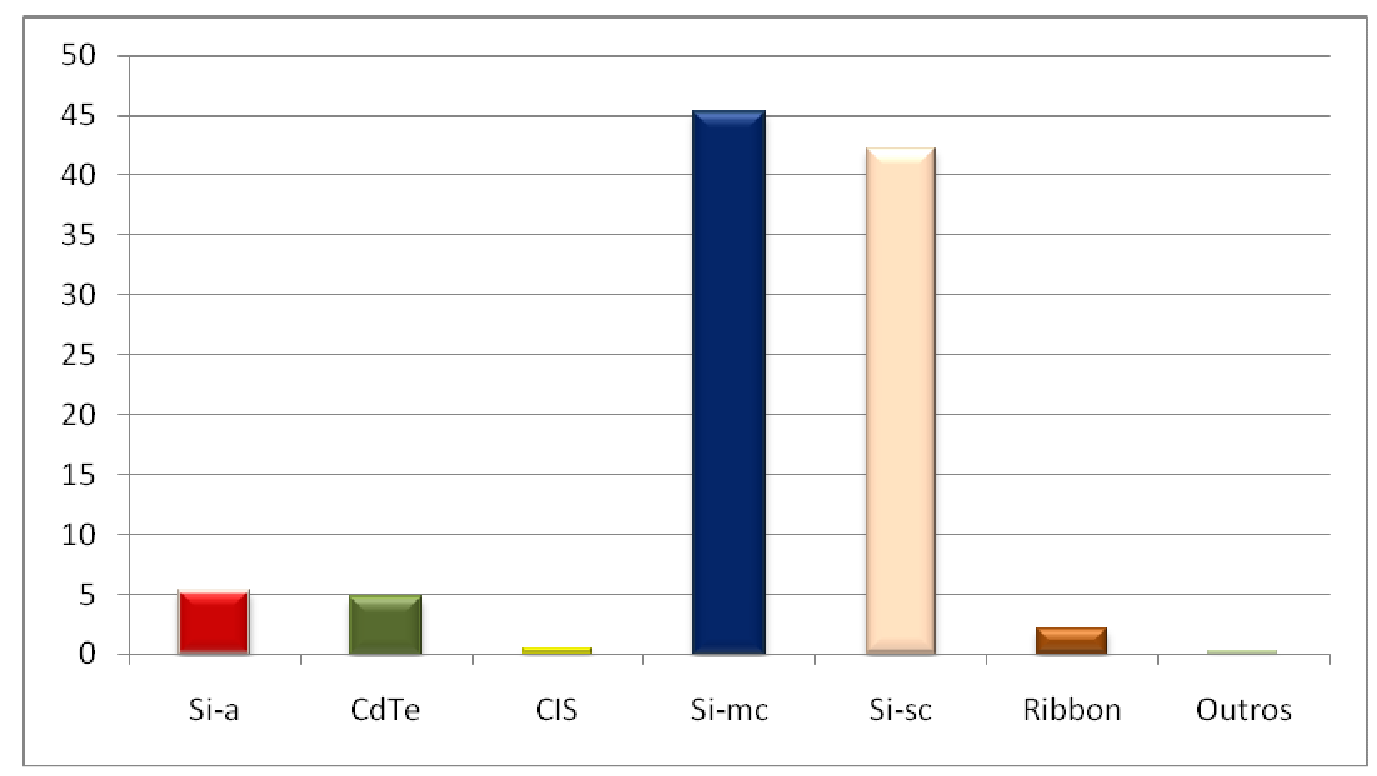

Figura 4.11 - Percentual de participação das diferentes tecnologias no mercado fotovoltaico (adaptado a partir de Raugei \& Frankl, 2009).

Apesar de o mercado atual estar fortemente direcionado para as tecnologias de filmes finos, células e módulos baseados em Si-sc continuam dominando a indústria FV global. Particularmente nos EUA, as células/módulos de Si-sc contabilizaram em 2007 , cerca de $60 \%$ do total de vendas. Comparado ao ano de 2005 , de $76 \%$, o valor atual representa um considerável declínio do percentual de divisão do mercado.

Em termos de aplicação, em 1990 as tecnologias FV eram usadas principalmente como sistemas autônomos, para eletrificação rural e aplicações de pequena escala. Nos dias atuais, o número de sistemas conectados à rede aumentou significativamente. A Europa e o Japão tem o maior número de sistemas FV conectados à rede de distribuição, na maioria integrada às edificações. A distribuição da divisão do mercado para as instalações conectadas a rede está crescendo significativamente e alcançou em 2008 , o valor de $76 \%$ da capacidade acumulada e instalada em países participantes do PVSP (IEA - PVSP, 2009).

Contudo, os sistemas correntes conectados à rede são viáveis economicamente somente em conexão com programas de incentivos e suporte ao mercado. Estes programas têm sido implementados como instrumentos de políticas governamentais no Japão, Alemanha e Estados Unidos, visando o desenvolvimento da indústria local e a implementação em larga escala de sistemas FV (HOFFMAN, 2005). 
A legislação federal norte-americana - Crédito de Investimento em Imposto (Investment Tax Credit - ITC), por exemplo, teve um grande impacto no mercado FV, em 2008. A ansiedade sobre a possível expiração do ITC, no início de 2009, encorajou uma corrida dos empresários e de consumidores para instalar sistemas FV utilizando os créditos existentes (IEA- PVSP, 2009).

Outras ações, tais como, a Iniciativa Solar Americana (Solar America Iniciative SAI) do Departamento de Energia dos EUA (Department of Energy - DOE) e o programa de Divisão Solar - SolarShares Program da capital da Califórnia Sacramento, auxiliaram na aceleração da adoção do uso de energia solar no nível governamental e local, respectivamente.

Exemplos de políticas públicas para o uso de energia solar que impactaram o mercado, aumentando a geração de eletricidade a partir de energias renováveis e reduzindo os gases do efeito estufa em cidades densamente povoadas, são notórios no Japão (Programa de Disseminação de Sistemas FV Residenciais) e na Alemanha (Programa Integrado de Energia e Clima - Lei de Fontes de Energia Renováveis) (IEAPVSP, 2009).

Embora os investimentos iniciais nas tecnologias FV estivessem relacionados às preocupações com a segurança energética, o contínuo foco no desenvolvimento e aplicação é devido principalmente ao seu positivo impacto ambiental. Conforme Fukurozaki \& Paschoal (2010), os sistemas FV podem servir a demanda corrente e projetada de energia com similar escala de emissões de gases do efeito estufa que as outras opções de sistemas energéticos de baixa emissão de carbono.

\subsection{Impactos Ambientais}

Os módulos fotovoltaicos (FV) têm sido identificados como uma promissora e "regenerativa tecnologia" de geração de eletricidade. Segundo Stopatto (2006), as plantas de energia fotovoltaica não produzem emissões poluidoras durante a sua operação e podem ser consideradas como "limpas". De fato, os impactos significativos são decorrentes principalmente das atividades de mineração da matéria prima (silício) e da manufatura dos painéis (SORESEN, 2004).

Neste sentido, observa-se que a prática de avaliar o ciclo de vida de tecnologias de energia solar, principalmente a fotovoltaica, é comumente utilizada para 
identificar e analisar os impactos ambientais específicos de componentes (silício, módulos e BOS) e do inteiro sistema. Os estudos de Avaliação do Ciclo de Vida (ACV) de sistemas fotovoltaicos ${ }^{5}$ (ALSEMA, 1998; 1999; 2000) reforçaram as vantagens ambientais da aplicação da energia FV (RAUGEI \& FRANKL, 2009), tais como baixas emissões, ausência ou mínima produção de ruídos, entre outros, durante a operação.

Por outro lado, tais estudos também comprovaram os impactos negativos das outras etapas da cadeia do produto (uso intensivo de materiais e energia, entre outros), bem como as influências das variáveis ambientais no direcionamento do desenvolvimento tecnológico e na inserção das tecnologias fotovoltaicas no mercado (FTENASKIS et. al., 2005; FTENASKIS \& ALSEMA, 2006; FTENASKIS et. al., 2008).

Um exemplo da aplicação prática das análises de ACV resultou, por exemplo, no desenvolvimento de uma pasta à base de água que substituiu a comumente utilizada (à base de solventes orgânicos) no processo de metalização serigráfica dos módulos fotovoltaicos (TSUO et. al, 1998).

Soma-se ainda, o desenvolvimento de vários processos de reciclagem, visando o reaproveitamento de materiais desperdiçados (como silício ultrapuro resultante da fresa do lingote), rejeitados ou no fim da vida útil (como módulos). Tais aprimoramentos conduziram a uma melhoria no desempenho ambiental (redução no uso de recursos e de emissões poluentes) e, sobretudo, em um considerável interesse das partes envolvidas (indústrias, governos e comunidade acadêmica) pelas variáveis ambientais relacionadas às tecnologias de energia solar.

Não obstante, uma das questões mais controversas da energia fotovoltaica, decorrentes da análise ambiental é se a quantidade de energia necessária para produzir um sistema completo é menor ou maior que a energia produzida durante sua vida útil. No passado, os primeiros sistemas fotovoltaicos eram consumidores de energia em vez de produtores, o que em outras palavras, significava que o tempo de retorno de investimento em energia (Energy Payback Time - EPBT) desses sistemas era maior do que a sua vida útil. Contudo, este cenário alterou-se e os modernos sistemas FV apresentam, atualmente, um EPBT cerca de 5 vezes menor do que sua vida útil (30 anos).

\footnotetext{
${ }^{5}$ Diversos estudos sobre a ACV de sistemas fotovoltaicos, realizados desde 1990 até os dias atuais, se encontram disponibilizados na literatura.
} 
È importante destacar que o EPBT é uma métrica de avaliação do desempenho ambiental com foco no balanço energético, extensivamente utilizada nos estudos de ACV de sistemas de energia solar ${ }^{6}$. Análogo ao indicador - Tempo de Retorno de Investimento (Payback Time - PT), utilizado em análises econômicas, o EPBT indica quanto tempo será necessário para que o sistema FV produza a mesma quantidade de energia consumida no seu inteiro ciclo de vida (desde a extração de matériasprimas, incluindo o transporte, manufatura de componentes, instalação, uso e descomissionamento). Informações mais aprofundadas sobre a Avaliação do Ciclo de Vida e do EPBT são apresentados no capítulo 5.

\footnotetext{
${ }^{6}$ Comparativamente, os sistemas de gaseificação da biomassa não apresentam, com a mesma frequência, o uso desta métrica nas análises ambientais disponíveis na literatura.
} 


\section{VISÃO GERAL}

Neste trabalho, além da pesquisa bibliográfica, utilizou-se o procedimento convencional da Avaliação do Ciclo de Vida (ACV), conforme a última atualização da norma brasileira de Gestão Ambiental: Avaliação do Ciclo de Vida - Requisitos e Orientações (ABNT- NBR/ISO 14044, 2009). Os dois principais critérios que condicionaram o uso desta metodologia, em detrimento das outras existentes para a avaliação ambiental ${ }^{1}$, são:

- A constatação das contribuições da ACV no desenvolvimento e inovação na tecnologia $\mathrm{CaC}$, observadas no estudo realizado anteriormente (FUKUROZAKI, 2006). Portanto, há a necessidade da continuidade da aplicação desta ferramenta no âmbito brasileiro, principalmente na análise de sistemas energéticos.

- A grande experiência do uso da ACV na avaliação de sistemas fotovoltaicos, suas contribuições no aperfeiçoamento do seu desempenho ambiental, desenvolvimento industrial e inserção no mercado (FUKUROZAKI et. al, 2010; FUKUROZAKI \& PASCHOAL, 2010).

Em linhas gerais, a ACV apresenta diversas características que a tornam atrativa para o uso na engenharia e nas indústrias ${ }^{2}$. Esta metodologia tem se destacado como um instrumento de análise qualitativo, quantitativo e bem estruturado, que foca os sistemas técnicos concomitantes às diversas questões de caráter ambiental. Isto é, os trade offs entre o meio ambiente e distintas partes do ciclo de vida de um sistema (produto ou serviço) são evidenciados e melhor compreendidos quando se utiliza a ACV.

Não obstante, a ACV apresenta vários tipos de aplicações, cada qual com particulares requerimentos metodológicos. Usualmente, tais requerimentos são direcionados em função da aplicação/objetivo do estudo, embora esta distinção não se encontre sempre clara em muitos manuais e guias de procedimentos.

\footnotetext{
${ }^{1}$ Como por exemplo, Avaliação do Risco Ecológico, Contabilidade do Fluxo de Materiais, Pegada Ecológica, entre outros.

2 A utilidade da ACV também é melhor compreendida quando esta é comparada com outras ferramentas de análise ambiental. Para uma exploração entre a relação da ACV com outros métodos de análise, o artigo de Bauman \& Cowell (1998) representa um ponto inicial de partida, em termos metodológicos. Também o relatório compilado por Wrisberg et. al. (2002) apresenta um completo panorama, onde diferentes metodologias são aplicadas e comparadas em estudos de casos.
} 
Neste sentido, este capítulo apresenta inicialmente uma síntese da metodologia da ACV (base conceitual), conforme a norma em vigor. Posteriormente são apresentados os procedimentos de análise específicos para atender os objetivos deste estudo, nos quais encontram-se descrições abrangentes sobre os principais conceitos envolvidos e os critérios de análise considerados no estudo.

Revisões sobre o histórico do desenvolvimento da ACV, atividades iniciais, experiências internacionais, estudos de casos, guias de procedimentos e aplicações não foram abordadas e podem ser consultadas nas referências aqui citadas e em diversos trabalhos, tais como, UNEP/SETAC (2000); Baumann \& Tilman (2004); Manzini \& Vezzoli (2005); Hendrickson et. al (2006); Fukurozaki (2006).

\subsection{Avaliação do Ciclo de Vida: Modelo Conceitual}

A ACV, também conhecida como Life Cycle Assessment - LCA, é uma metodologia para avaliar os impactos ambientais positivos ou negativos da cadeia produtiva de um bem ou serviço, cuja abordagem é do berço ao túmulo (cradle to grave). Ou seja, a avaliação inicia-se com a extração de recursos para criar o produto $^{3}$ e finaliza no ponto em que todos os materiais são devolvidos ao ambiente natural (Figura 5.1).

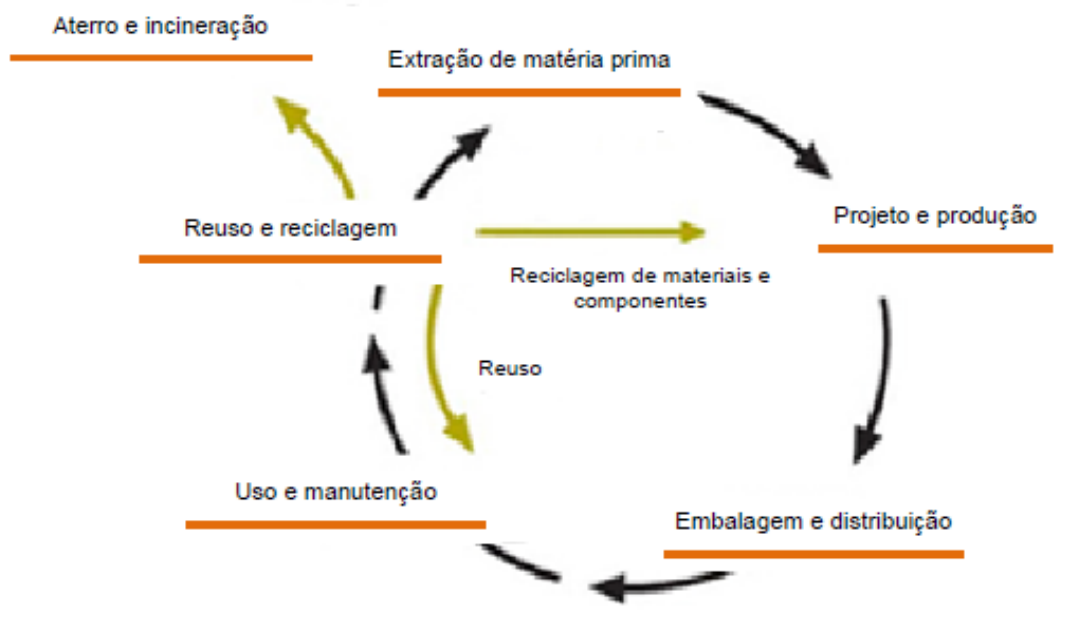

Figura 5.1 - Ilustração simplificada da abordagem da Avaliação do Ciclo de Vida (FUKUROZAKI, 2011).

Desta forma, a ACV permite estimar os impactos ambientais cumulativos, resultantes de todas as etapas do ciclo de vida, incluindo, frequentemente, impactos das fases não consideradas nas análises tradicionais, tais como, extração de

\footnotetext{
${ }^{3}$ Tal como na norma NBR ISO 14044 (2009), o termo produto também inclui serviços.
} 
matérias primas, transporte de material, reciclagem e disposição final. Ou seja, a ACV providencia uma visão holística dos aspectos ambientais envolvidos e, consequentemente, um quadro mais preciso dos reais intercâmbios entre o produto e o meio ambiente ( CALDEIRA-PIRES et. al, 2005).

Especificamente, a ACV é uma metodologia estabelecida pela Organização Internacional de Normalização - International Standardization Organization (ISO 14040, 1997) para avaliar os aspectos e os potenciais impactos ambientais associados a um produto, processo ou outra atividade econômica por meio de:

I. Compilação de um inventário de energia pertinente, contribuições de materiais e emissões ambientais;

II. Avaliação de potenciais impactos ambientais associados às contribuições e emissões identificadas;

III. Interpretação dos resultados obtidos nas constatações da análise do inventário e na avaliação de impactos.

O processo da ACV é sistemático, iterativo (Figura 5.2) e, tal como apresentado na norma NBR ISO 14044 (2009), consiste de quatro etapas sumarizadas por: i) definição do objetivo e escopo, ii) análise do inventário (ICV), iii) avaliação de impactos (AICV) e iv) interpretação de resultados.
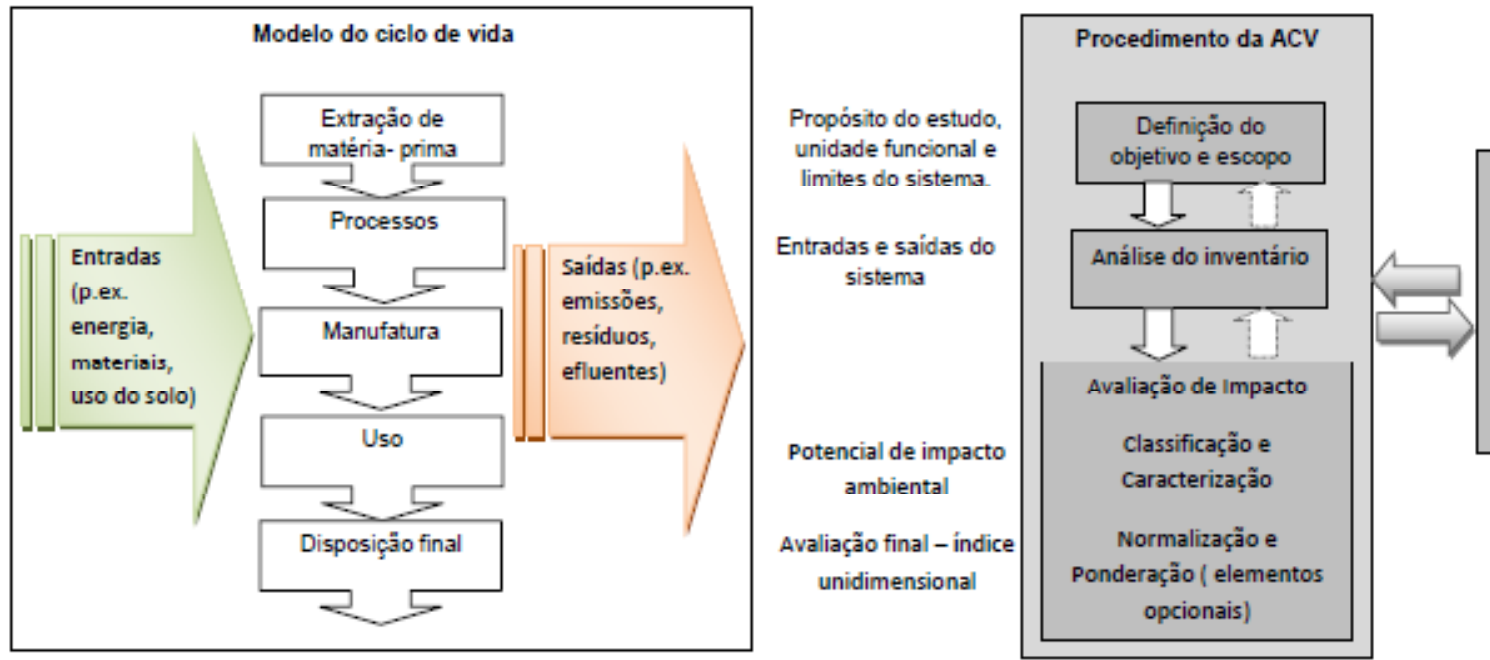

Figura 5.2 - Estrutura conceitual do ciclo de vida e da metodologia ACV (baseado em Tilman \& Baumann, 1995).

O objeto de estudo e o objetivo pretendido para a condução de uma ACV determinam o escopo da mesma, incluindo as fronteiras/limites do sistema (onde 
iniciar e parar a análise), o nível de detalhamento e os pressupostos majoritários ${ }^{4}$ considerados no estudo, bem como a medida de quantificação da função do sistema (unidade funcional). Dependendo do objetivo do estudo em particular, a profundidade e a abrangência podem variar consideravelmente ${ }^{5}$.

No campo da ACV, notadamente, o foco dessa ferramenta encontra-se em duas etapas analíticas, na análise do inventário e na avaliação de impactos do ciclo de vida (AICV) (UNEP/SETAC, 2001), em ambas, a principal técnica utilizada é a modelagem (Pré Consultants, 2004).

O Inventário do Ciclo de Vida (ICV) pode ser descrito como um modelo do sistema técnico utilizado para produzir, transportar, usar e eliminar um produto, no qual se estabelece um diagrama de fluxos, onde todos os processos relevantes e as entradas e saídas do sistema são compilados (Figura 5.3). O propósito do ICV consiste em identificar e quantificar os recursos requeridos do meio e as emissões geradas para os diversos compartimentos ambientais.

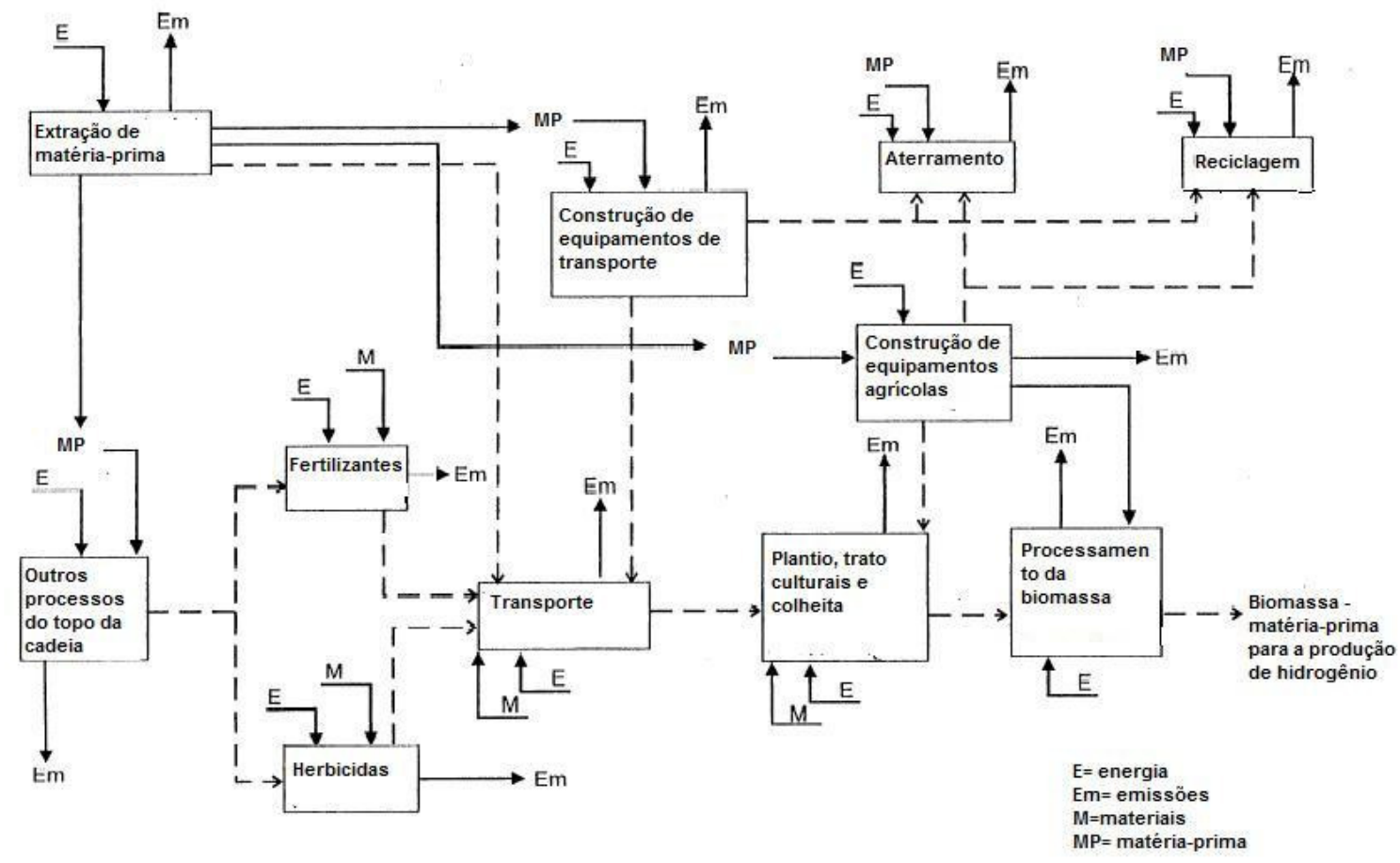

Figura 5.3 - Exemplo de um diagrama simplificado para ACV de um modelo de sistema técnico - produção de biomassa e transporte (baseado em MANN \& SPATH, 1997).

\footnotetext{
4 Tipicamente são apresentados os principais pressupostos/considerações, isto é, aqueles relacionados a um conjunto de dados e não a dados específicos (BAUMANN \& TILMANN, 2004).

5 Cabe ressaltar que outros fatores, tais como, a disponibilidade e acesso aos dados produtivos do sistema também são fatores que influenciam esta etapa, ou melhor, determinam o grau de profundidade, detalhamento e fronteiras do sistema.
} 
Por sua vez, a Avaliação de Impactos do Ciclo de Vida (AICV) é dirigida à avaliação da significância das contribuições relacionadas à extração de recursos e emissões para o ambiente obtidas no inventário. Para tanto, utiliza-se modelos de mecanismos ambientais, nos quais os resultados do inventário podem ser traduzidos em potenciais impactos (e/ou danos), tais como mudanças climáticas, acidificação, efeitos toxicológicos a saúde humana e aos ecossistemas, depleção do ozônio estratosférico, entre outros (Figura 5.4).

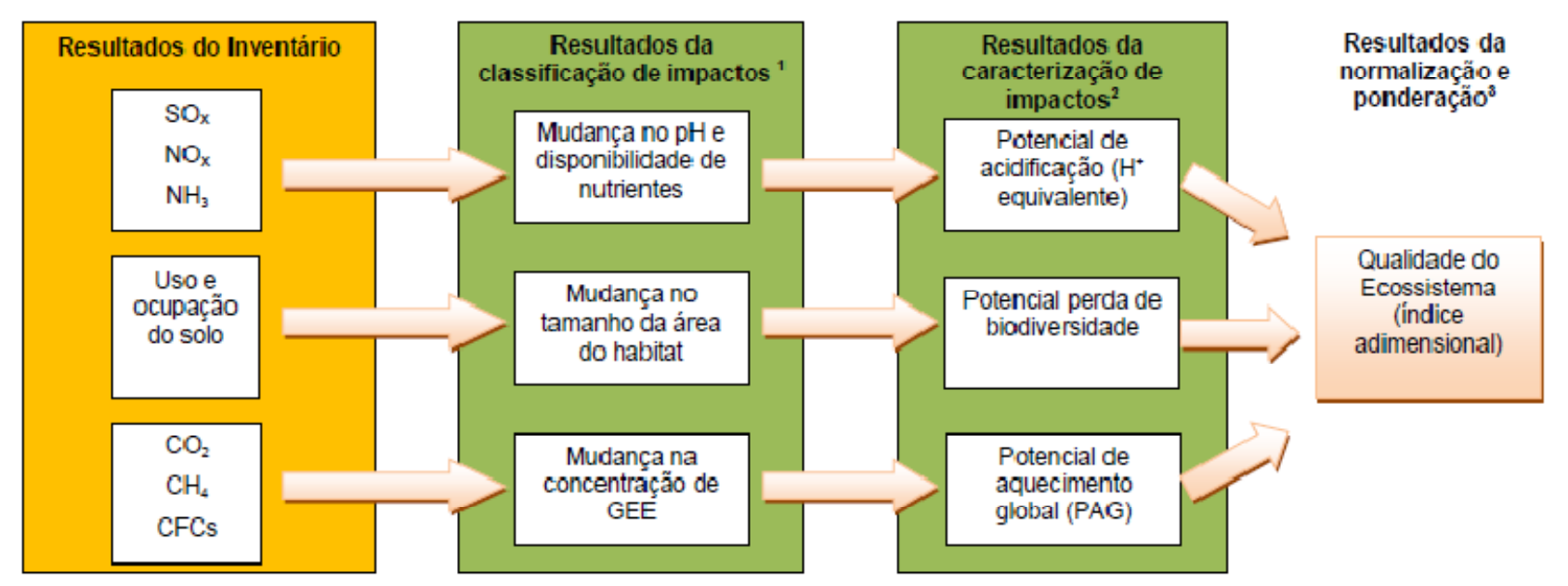

1) Classificação: relaciona os resultados do inventário âs respectivas categorias de impactos

2) Caracterização: calcula a extensão dos impactos por categoria de impacto

3) Normalização e ponderação- converte e agrega os resultados da caracterização das categorias de impactos, considereando a magnitude do impacto e uma escala de valores (elementos de análises apcionais)

Figura 5.4 - Exemplo simplificado de uma avaliação de impacto do ciclo de vida (FUKUROZAKI, 2011).

As combinações dos resultados obtidos no ICV e na AICV podem tomar a forma de conclusões e recomendações úteis para a tomada de decisão das diferentes partes interessadas em relação: a escolha de processos e produtos menos impactantes, a identificação de oportunidades de melhorias dos aspectos ambientais dos produtos e processos, ao planejamento estratégico, o projeto ou reprojeto, a seleção de indicadores de desempenho ambiental, a rotulagem ecológica, dentre outros.

Baumann \& Tilman (2004) relatam que há uma série de guias de procedimentos de como conduzir uma $\mathrm{ACV}$, tal como o Código de Prática da SETAC, procedimentos de análise de ACV oriundos de países como a Holanda 
(CML/NOH), Estados Unidos (USEPA), Países Nórdicos (NORD) e Dinamarca (EDIP).

A maioria destes estudos foi escrita antes da padronização ter sido considerada e realizaram importantes contribuições ao desenvolvimento das normas ISO. Estes guias são mais detalhados nas suas recomendações do que a norma e, a maioria destes, incluem métodos para a avaliação de impactos. Alguns métodos descrevem como a ACV pode dar suporte para um propósito específico. Por exemplo, o método holandês Eco-indicator 99 (Eco-indicador 99) foi projetado para propósitos de desenvolvimento e redesign de produtos e, o dos Países Nórdicos, foi elaborado com foco em como desenvolver os "fatores chaves de identificação" da ACV.

De fato, embora as terminologias entre os procedimentos acima e a norma sejam relativamente diferentes (uma vez que foram escritas antes ou paralelamente à norma ISO), a norma não especifica claramente o procedimento para a modelagem do sistema (partes envolvidas e escopo), não faz distinção ou recomendações sobre quais metodologias de impacto são mais apropriadas para a ACV e nem estabelece requerimentos para a publicação dos resultados (transparência).

Diante das considerações expostas acima, bem como da importância do ICV e AICV como pontos críticos da avaliação do ciclo de vida, a seção a seguir apresenta os procedimentos específicos considerados neste trabalho, particularmente nestas duas etapas analíticas de modelagem.

\subsection{Inventário do Ciclo de Vida}

O questionamento sobre onde iniciar e parar de contabilizar a energia, o uso de materiais e as emissões resultantes nos processos da cadeia produtiva é um fator chave da análise, uma vez que o sistema técnico de um produto se relaciona com vários outros setores (como por exemplo, transporte, energia, materiais, entre outros) que, de uma forma ou outra, colaboram para os potenciais impactos (ou desempenho ambiental) do produto.

Além das questões relacionadas ao objeto de análise e o propósito do estudo, as decisões sobre quais fluxos de entrada e saída do inventário devem ser contabilizados, comumente, consideram-se as etapas (processos) ou estágios do 
ciclo onde há restrições para executar a avaliação. Frequentemente, a determinação dos limites é realizada considerando a disponibilidade de dados sobre os processos envolvidos (MANN \& SPATH, 1997), de tal forma que isto define o escopo e como é conduzida a análise do estudo.

Destarte, em adição a contabilidade dos fluxos de materiais e energia dos processos de interesse, àqueles envolvidos com a extração de matéria prima e produção de reservas intermediárias ${ }^{6}$ foram, quando possível, incluídos na análise do presente estudo. Similarmente, também incluiu-se a disposição de resíduos e materiais processados nos limites do sistema.

Especificamente neste trabalho, a modelagem dos sistemas técnicos de gaseificação da biomassa (GB) e de energia solar fotovoltaica (FV) baseou-se, principalmente, nos inventários (fluxos de materiais e energia) disponíveis no banco de dados do Ecoinvent V.2.01 (2007) e na base do software GaBi 4 Professional. Ambos apresentam um banco de dados com informações oriundas de patentes, literatura especializada e da indústria.

$\mathrm{Na}$ modelagem do sistema de gaseificação, considerou-se a vasta experiência comercial em plantas de gaseificação da madeira, nas quais as tecnologias de gaseificação de leito fixo (LFX) e de leito fluidizado (LFL) possuem maior participação no mercado. Visto que ambas as tecnologias também apresentam vantagens e desvantagens para a produção futura de hidrogênio e outros vetores energéticos, os dois sistemas (LFX e LFL) foram analisados na ACV (Cf. capítulo 3).

Particularmente, para modelar o sistema fotovoltaico, o estudo sobre os diferentes tipos de tecnologias de energia solar, processos de produção de células e painéis, irradiação solar, bem como a ACV e Energy Packback Time (EPBT), foi conduzido durante o programa de doutorado sanduíche na Universidade da Califórnia - Merced (UC Merced). Neste caso, a modelagem do sistema FV também

\footnotetext{
${ }^{6}$ As reservas intermediárias são algumas vezes referenciadas como materiais auxiliares, visto que são usados indiretamente na manufatura do produto final (como por exemplo, inversores, molduras de alumínio, no caso de painéis solares).

${ }^{7}$ O Ecoinvent configura-se em um banco de dados de referência para Inventários do Ciclo de Vida (ICV), no qual estão inclusos dados (atividades, processos e infraestrutura) das áreas de energia, produtos químicos, agricultura, serviços de transporte e tratamento de resíduos, entre outros. Os dados representam a situação de produção e suprimento para o contexto do Norte Europeu e condições globais.
} 
METODOLOGIA

considerou as características da planta de energia solar da UC Merced (como por exemplo, potência instalada e tipo de tecnologia).

\subsection{Análise do Balanço Energético}

Diferente das múltiplas tecnologias de energia solar, os estudos de ACV de sistemas de energia convencionais (incluindo os de gaseificação) encontrados na literatura, tradicionalmente não utilizam a métrica Tempo de Retorno de Investimento em Energia (EPBT) na avaliação do seu desempenho ambiental (Cf. capítulo 4). Neste sentido, dada à importância da mesma na análise de sistemas de energias sustentáveis, foram calculados o EPBT das diferentes tecnologias aqui estudadas.

Portanto, outra métrica necessária para a análise do EPBT, foi utilizada, a saber: Demanda Acumulada de Energia, também conhecida como Cumulative Energy Demand (CED) ${ }^{8}$, conforme apresentado a seguir.

\subsubsection{Demanda Acumulada de Energia (CED)}

Tendo em vista que o objetivo de um sistema de conversão energética é obter energia, uma medida comum para o sucesso deste é a razão entre a energia produzida e a energia consumida em um sistema específico (Hagens \& Mulder, 2008). Diversas abordagens para quantificar o coeficiente de sucesso de uma dada tecnologia podem ser encontradas na literatura, incluindo: Fator de Produção de Energia - Energy Yield Factor (HALL et. al., 1986), Ganho Energético - Energy Gain (TAINTER, 2003) e Tempo de Retorno do Investimento em Energia - Energy Payback Time (KEIOLEIAN \& LEWIS, 1997; ALSEMA, 1998).

Notadamente, é possível observar que não há uma terminologia uniforme para análise do desempenho energético (PATEL, 2003). Por exemplo, dependendo da comunidade científica, um dos termos dados - Requerimento de Energia Total Gross Energy Requirements (IFIAS 1978) ou Demanda Acumulada de Energia Cumulative Energy Demand (KLOPFER, 1997) é atualmente utilizado para indicar o consumo equivalente de energia primária na cadeia de um produto ou a energia consumida em um determinado sistema. No presente estudo, adotou-se os termos CED e EPBT, considerando a sua ampla utilização na análise de sistemas energéticos.

\footnotetext{
8 Também conhecida como Grey Energy ou Hidden Energy (SCHAEFER \& HAGERDON, 1992), Embodied Energy ( WILSON \& YOUNG, 1995), Gross Energy Requirement (ALSEMA, 1998)
} 
O CED é definido como a somatória dos requerimentos de entrada de energia em todos os estágios do ciclo de vida do sistema. Isto é, desde a energia consumida para construir toda a planta energética (materiais, equipamentos, entre outros) aqui referida como manufatura $\left(E_{M}\right)$, incluindo a energia requerida para a instalação da planta $\left(E_{1}\right)$, a operação e/ou produção de energia $\left(E_{U}\right)$ até o descomissionamento $\left(E_{D}\right)$ do sistema após sua vida útil, desta forma:

$$
\mathrm{CED}=\mathrm{E}_{M}+\mathrm{E}_{1}+\mathrm{E}_{U}+\mathrm{E}_{\mathrm{D}}[\mathrm{MJ}]
$$

O consumo de energia nos diferentes estágios do ciclo de vida pode ser distinguido em duas principais categorias de energia secundária: energia térmica e energia elétrica. Em determinados casos, adicionalmente, utiliza-se a categoria "não energética" ou "reserva de energia", no qual contabiliza-se o valor calorífico de um material quando este também pode ser considerado como um vetor energético.

Para análise direta dos dados de energia, utiliza-se o Equivalente em Energia Primária (EEP) ${ }^{9}$, aplicando as respectivas eficiências de conversão $(\eta)$ de energia elétrica $\left(E_{e l}\right)$ e/ou térmica $\left(E_{\text {ter }}\right)$, a fim de obter o seu correspondente no fluxo de entrada em energia primária $(\mathrm{MJ})$ :

$$
\begin{aligned}
& E_{\text {EEP }}=\frac{E_{\text {el }}}{\eta_{\text {el }}}[M J] \\
& E_{\text {EEP }}=\frac{E_{\text {ter }}}{\eta_{\text {ter }}}[M J]
\end{aligned}
$$

É importante destacar que a somatória de energia utilizada nos seguintes estágios do ciclo de vida do sistema, manufatura $\left(E_{M}\right)$, instalação $\left(E_{1}\right)$ e descomissionamento $\left(E_{\mathrm{D}}\right)$, são independentes do tempo ${ }^{10}$, de tal forma que:

\footnotetext{
${ }^{9}$ Cf. Alsema (1998)

${ }^{10}$ Cf. Nussbaumer \& Oser (2004)
} 


$$
\mathrm{E}_{0}=\mathrm{E}_{\mathrm{M}}+\mathrm{E}_{\mathrm{I}}+\mathrm{E}_{\mathrm{D}}[\mathrm{MJ}]
$$

Por outro lado, a demanda de energia primária durante a utilização da planta $\left(E_{U}\right)$ é dependente do tempo ${ }^{8}(t)$, neste caso contabiliza-se o tempo de vida útil da planta energética $(t \omega)$ :

$$
E_{U}=\int_{0}^{t \omega} \dot{E}_{U}(t) d t[M J]
$$

onde:

$\dot{\mathbf{E}}_{\mathrm{U}}$ : corresponde a demanda de energia primária na fase de operação do sistema.

$(t)$ : corresponde ao tempo de vida útil da planta energética estudada.

No presente estudo, a energia consumida na fase de uso e/ ou operação ( $\left.E_{\mathrm{U}}\right)$ está estritamente relacionada à função dos processos ${ }^{11}$, como por exemplo, secagem da biomassa e operação do arranjo FV (movimentação do conjunto de painéis solares - rastreamento do sol). Desta forma, o consumo de energia primária durante a utilização da planta (Eu) é distinguido por:

$$
\mathrm{E}_{\mathrm{U}}=\mathrm{E}_{\mathrm{A}}+\mathrm{F}[\mathrm{MJ}]
$$

onde:

$\mathrm{E}_{\mathrm{A}}$ : corresponde a demanda auxiliar de energia primária durante a utilização da planta.

F: corresponde a demanda de energia primária relacionada ao consumo de combustível durante a fase de utilização (operação) da planta.

Entretanto, o consumo de combustíveis também ocorre no transporte de materiais, produtos intermediários, produto final, equipamentos e resíduos em outras etapas do ciclo de vida ( $\left.E_{M}, E_{1}, E_{D}\right)$, nas quais este consumo $\left(F_{T, O}\right)$ não é dependente do tempo de vida útil, de forma que:

$$
\mathrm{F}_{\mathrm{T}, \mathrm{O}}=\mathrm{F}_{\mathrm{T}, \mathrm{M}}+\mathrm{F}_{\mathrm{T}, \mathrm{I}}+\mathrm{F}_{\mathrm{T}, \mathrm{D}}[\mathrm{MJ}]
$$

onde:

$\mathrm{F}_{\mathrm{T}, \mathrm{M}:}$ corresponde ao consumo de combustíveis no transporte utilizado durante a etapa de manufatura.

\footnotetext{
11 Portanto, estão excluídos os consumos de energia relacionados: i) à função dos trabalhadores dentro da área de operação (climatização, controle de saúde e segurança, entre outros) e, ii) à função dos trabalhadores fora da área de operação (computadores, entre outros).
} 
$\mathrm{F}_{\mathrm{T}, \mathrm{I}}$ : corresponde ao consumo de combustíveis no transporte utilizado durante a etapa de instalação.

$\mathrm{F}_{\mathrm{T}, \mathrm{D}}$ : corresponde ao consumo de combustíveis no transporte utilizado durante a etapa de descomissionamento.

Para comparar dois sistemas de energia distintos ${ }^{12 .}$, em termos de contribuição de combustíveis não renováveis $\left(F_{N R}\right)$ e renováveis $\left(F_{R}\right)$, o consumo de combustíveis (F) é expresso desta forma:

$$
\mathrm{F}=\mathrm{F}_{\mathrm{NR}}+\mathrm{F}_{\mathrm{R}} \quad[\mathrm{MJ}]
$$

Por fim, a CED integrada ao tempo de vida útil é determinada por:

$$
\mathrm{CED}=\mathrm{E}_{\mathrm{o}}+\mathrm{F}_{\mathrm{T}, \mathrm{O}}+\int_{0}^{\mathrm{t} \omega} \dot{\mathrm{E}}_{\mathrm{U}}(\mathrm{t}) \mathrm{dt}[\mathrm{MJ}]
$$

Os resultados do CED são apresentados em três categorias: i) recursos energéticos não renováveis (óleo cru, carvão mineral, lignina, gás natural e urânio); ii) recursos de energia renovável e iii) recursos de energia em materiais (o qual representa o material considerado como "reserva de energia" (conforme discutido anteriormente) .

Visto que o Valor Calorífico Líquido - Net Calorific Value (NCV) ${ }^{13}$ indica um valor mais apropriado na avaliação da energia disponível para um uso subsequente (MCKENDRY, 2002), os resultados do CED dos sistemas aqui estudados são expressos pelo valor calorífico líquido (MJ).

Ademais, dada às características de operação de cada sistema aqui estudado, considerações específicas quanto ao procedimento de cálculo do CED dos sistemas de gaseificação e de energia solar são apresentadas a seguir.

\section{CED do Sistema de Gaseificação da Biomassa}

Nos sistemas de gaseificação da biomassa, a demanda de energia primária do combustível $(F)$ está relacionada com as seguintes contribuições:

\footnotetext{
12 Esta comparação permite a identificação do sistema que consume menos combustível não renovável e menos combustível no total. Neste caso, esta avaliação pode servir de base para a tomada de decisão.

13 Também nomeado como Valor Calorífico Inferior - Lower Heating Value (LHV) ou, ainda, Poder Calorífico Inferior (PCI),
} 


$$
\mathrm{F}=\mathrm{F}_{\mathrm{C}}+\mathrm{F}_{\mathrm{P}}+\mathrm{F}_{\mathrm{T}}[\mathrm{MJ}]
$$

onde:

$\mathrm{F}_{\mathrm{C}:}$ corresponde ao poder calorífico do combustível utilizado na operação do sistema ou planta (biomassa).

F: corresponde ao pré- tratamento do combustível, por exemplo, secagem e cominuição.

$\mathrm{F}_{\mathrm{T}}$ : corresponde ao combustível fóssil utilizado no transporte da biomassa.

Segundo Nussbaumer \& Oser (2004), a eficiência de uma planta não é adequadamente validada quando o consumo de combustível (predominantemente de energia primária renovável) é contabilizado durante a operação da planta $\left(F_{C}\right)$, pois isto conduz a baixos coeficientes de produção de energia. Desta forma, assume-se que:

$\mathrm{F}_{\mathrm{C}}$ : no caso da biomassa é $100 \%$ renovável $\left(\mathrm{F}_{\mathrm{C}}=0\right)$.

$F_{p:}$ a energia elétrica consumida no sistema é não renovável e parte da energia requerida em forma de calor é fornecida pelo próprio sistema.

$\mathrm{F}_{\mathrm{T}}$ : são $100 \%$ não renováveis $\left(\mathrm{F}_{\mathrm{T}, \mathrm{R}}=0\right)$.

Não obstante, Mann \& Spath (1997) relatam que o consumo de combustíveis durante a operação $\left(\mathrm{F}_{\mathrm{C}}\right)$ da planta de gaseificação, não é contabilizada na análise energética, pois, no caso da biomassa, estes são repostos em uma taxa igual ou maior do que a consumida.

\section{$\underline{\text { CED do Sistema de Energia Solar Fotovoltaica }}$}

Tal como nos sistemas de gaseificação, a energia consumida durante a fase de uso $\left(E_{U}\right)$ é dependente do tempo. No entanto, assume-se que a energia utilizada durante a fase de uso ( $\left.E_{U}\right)$ nos sistema FV é negligenciável (portanto igual a zero), tal como verificado em Alsema (2000) ${ }^{14}$ e Koroneos et. al ( 2006). Soma-se, ainda, os seguintes pressupostos:

I. A demanda primária de energia auxiliar $\left(E_{A}\right)$ para a movimentação dos painéis solares (rastreamento do sol) é desprezível ou, nula (no caso em que não há rastreamento do sol). Assim sendo, $E_{A}=0$.

\footnotetext{
14 De fato, este mesmo autor discute em outra publicação (Alsema, 1998) as controvérsias e/ou confusões, bem como as dificuldades em estabelecer o consumo de energia relacionado a esta fase. Koroneos et. al (2006), com base em outros autores (ALSEMA, 1998; LEWIS \& KEOLEIAN, 1997), também assume que nesta fase o consumo é igual à zero.
} 
II. Não ocorre nenhuma das contribuições referentes ao consumo de combustíveis $\left(F_{C}, F_{P}\right.$ e $\left.F_{T}\right)$ durante a etapa de uso $\left(E_{U}, F\right)$ do sistema, uma vez que a fonte de energia (irradiação solar) do sistema FV encontra-se disponível diretamente no local; diferente da gaseificação, no qual o principal recurso (biomassa) necessita ser transportada para a planta e pré-tratada. Portanto, $\mathrm{F}=0$.

Desta forma, no sistema FV, o CED comumente é expresso por:

$$
\mathrm{CED}=\mathrm{E}_{\mathrm{M}}+\mathrm{E}_{\mathrm{T}}+\mathrm{E}_{\mathrm{I}}+\mathrm{E}_{\mathrm{U}}+\mathrm{E}_{\mathrm{D}}[\mathrm{MJ}]
$$

onde:

$\mathrm{E}_{\mathrm{M}}$ : corresponde à demanda de energia primária durante a manufatura do módulo (incluindo todos os materiais e processos intermediários necessários para a produção do módulo).

$\mathrm{E}_{\mathrm{T}}$ : corresponde à demanda de energia primária durante o transporte de materiais e do módulo. $\mathrm{E}_{\text {I: }}$ corresponde à demanda de energia primária durante a instalação do módulo ou planta.

Eu: corresponde à demanda de energia primária durante a operação do módulo ou planta.

$\mathrm{E}_{\mathrm{D}}$ : corresponde à demanda de energia primária durante o descomissionamento do módulo ou planta.

No caso do sistema $F V$, o uso de combustíveis $(F)$, renováveis ou não, é representado pela variável $\mathrm{E}_{\mathrm{T}}$ que não é dependente do tempo, pois está estritamente relacionado ao consumo de combustíveis no transporte $\left(\mathrm{F}_{\mathrm{T}, \mathrm{O}}\right)$ de materiais, equipamentos, entre outros, durante os estágios de manufatura, instalação e descomissionamento $\left(E_{M}, E_{I}\right.$ e $\left.E_{D}\right)$. Assim, o CED do sistema FV pode ser definido por:

$$
\mathrm{CED}=\mathrm{E}_{\mathrm{O}}+\mathrm{F}_{\mathrm{T}, \mathrm{O}}[\mathrm{MJ}]
$$

\subsubsection{Tempo de Retorno de Investimento em Energia (EPBT)}

Uma vez que o EPBT indica o tempo (anos) necessário para que o sistema energético produza a mesma quantidade de energia investida no seu inteiro ciclo de vida (CED) (Cf. capítulo 4), o procedimento de cálculo para este parâmetro é dado por:

$$
\mathrm{EPBT}=\frac{\mathrm{E} \text { entrada }(\mathrm{MJ})}{\mathrm{E} \text { saída }(\mathrm{MJ})}
$$

onde: 
$E_{\text {entrada: }}$ corresponde a demanda acumulada de energia (CED) do sistema em MJ (NCV).

$\mathrm{E}_{\text {saída: }}$ corresponde à produção anual de energia líquida (PAE) do sistema em MJ (NCV).

Similarmente ao procedimento de cálculo do CED dos sistemas estudados, para o cálculo do EPBT dos sistemas de gaseificação e de energia fotovoltaica considerou-se as características da operação de cada sistema, conforme apresentados a seguir.

\section{EPBT do Sistema de Gaseificação da Biomassa}

Para contabilizar da produção anual de energia líquida (PAE) dos sistemas de gaseificação, assume-se que o sistema opera durante 24 horas e 330 dias por ano, sendo 35 dias dedicados à manutenção (Cf. DAURIAT, 2006). A produção de syngas dos sistemas de gaseificação é expressa por:

$$
\mathrm{PAE}=\mathrm{P}_{\mathrm{L}} \text { PCI. }\left(\mathrm{t}_{1}\right)
$$

onde:

$\mathrm{P}_{\mathrm{L}}$ : corresponde à produção líquida do syngas por dia $\left(\mathrm{Nm}^{3} /\right.$ dia $)$

PCI: corresponde ao poder calor inferior do syngas produzido pelo sistema (MJ/ $\left./ \mathrm{Nm}^{3}\right)$

$\left(t_{1}\right)$ : corresponde ao período de operação da planta durante 1 (um) ano

\section{EPBT do Sistema de Energia Solar Fotovoltaica}

Para o cálculo do EPBT nos sistemas FV, os seguintes pressupostos foram considerados:

A produção anual líquida (PAE) do sistema solar fotovoltaico depende:

I. Fator de qualidade (também conhecido Performance Ratio - PR): definido como a relação entre o atual retorno (potência produzida) e o potencial teórico de retorno de energia (potência instalada) de um sistema FV, dada por um número adimensional (Cf.IEC 61724) ${ }^{15}$ :

- Com base no relatório da International Energy Agency/ Photovoltaic Power System (IEA/PVPS - Agência Internacional

\footnotetext{
15 O PR é utilizado para indicar todas as perdas efetivas na saída de energia do arranjo fotovoltaico devido à temperatura dos painéis, incompleta utilização da irradiação, ineficiências ou falhas dos componentes do sistema. A norma do International Eletrotechinal Commission, (IEC 61724) dá as definições do PR, dos parâmetros envolvidos e os procedimentos padrão para o seu cálculo.
} 
de Energia/ Programa de Sistemas de Energia Fotovoltaica 2000), assume-se que o PR para o estudo é de 0,72. Este valor refere-se à média do $\mathrm{PR}$ obtido em plantas FV, conectadas a rede e que apresentaram uma boa manutenção.

II. Tipo de instalação, potência instalada e tecnologia utilizada:

- Tal como a planta da UC Merced, o tipo de instalação grounded monted (estruturada no solo - planta solar), a potência instalada (1 MW) e a tecnologia de silício monocristalino - Si-sc são consideradas para este estudo.

III. Localização geográfica da planta (média de irradiação anual):

- Martins et. al (2008) relatam que a irradiação solar global anual $(H)$, em qualquer região do Brasil, pode variar de 1500 a 2500 $\mathrm{kWh} / \mathrm{m}^{2}$. Para o cálculo neste trabalho, o valor da irradiação considerado é a média dos valores acima, a saber: 2000 $\mathrm{kWh} / \mathrm{m}^{2} / \mathrm{ano}$.

Portanto, a produção anual de energia líquida de um sistema FV com uma dada potência instalada $(\mathrm{kWp}){ }^{16}$, sob uma determinada irradiação $\left(\mathrm{kWh} / \mathrm{m}^{2} / \mathrm{ano}\right)$ e fator de qualidade, é dada por (Cf. ALSEMA \& WILD-SCHOLTEN, 2005) :

$$
\mathrm{PAE}=\mathrm{PR} \cdot \mathrm{H} \cdot \mathrm{kWp}
$$

onde:

$\mathrm{KW}_{\mathrm{P}}$ : corresponde à potência instalada, dada pela área total de incidência de irradiação solar no plano coletor (painel) versus a potência do painel por $\mathrm{m}^{2}\left(\mathrm{kWp} / \mathrm{m}^{2}\right)$

$\mathrm{O}$ resultado em eletricidade $(\mathrm{kWh} / \mathrm{kW} / \mathrm{ano})$, conforme mencionado anteriomente, é convertido para o seu correspondente em energia primária (valor calorífico líquido em MJ).

\footnotetext{
${ }^{16}$ Conforme Reis e Silveira (2001), a potência instalada de uma central fotovoltaica é considerada a potência obtida pelo arranjo durante o período de insolação máxima. Para a radiação solar máxima costuma-se usar o valor $1 \mathrm{~kW} / \mathrm{m}^{2}$.
} 


\subsection{Contabilidade dos Fluxos de Entrada e Saída do Sistema}

Rastrear um vasto número de fluxos de materiais e energia para e, a partir de cada processo produtivo dentro dos sistemas, representa um enorme desafio. Diversos software projetados para a avaliação do ciclo de vida são disponibilizados pelo mercado para auxiliar na execução deste trabalho. Alguns destes software são projetados para realizar qualquer tipo de ACV, outros foram projetados para atender determinados objetivos ou setores industriais específicos.

Segundo Baumann \& Tilmann (2004), a distinção entre os diferentes pacotes de software é baseada na capacidade computacional da ferramenta e estende-se para a qualidade dos dados utilizados nos cálculos da ACV. Divide-se em três tipos, conforme apresentado na figura $\mathbf{5 . 5}$.

O pacote de software da ACV qualitativa (Screening/ Qualitative LCA) é utilizado para realizar análises rápidas e robustas de ACV. Neste modelo, é possível visualizar um panorama do ciclo, no qual os resultados das avaliações são apresentados em um alto nível de agregação. Geralmente é aplicável para o desenvolvimento de produtos (por exemplo, Eco-it 1.0).

(1)

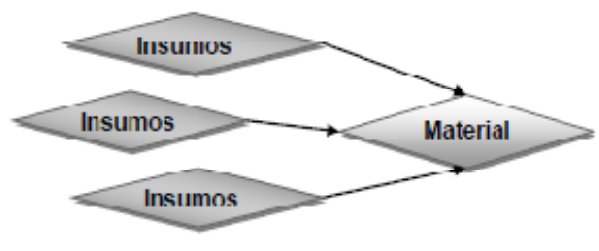

(2)

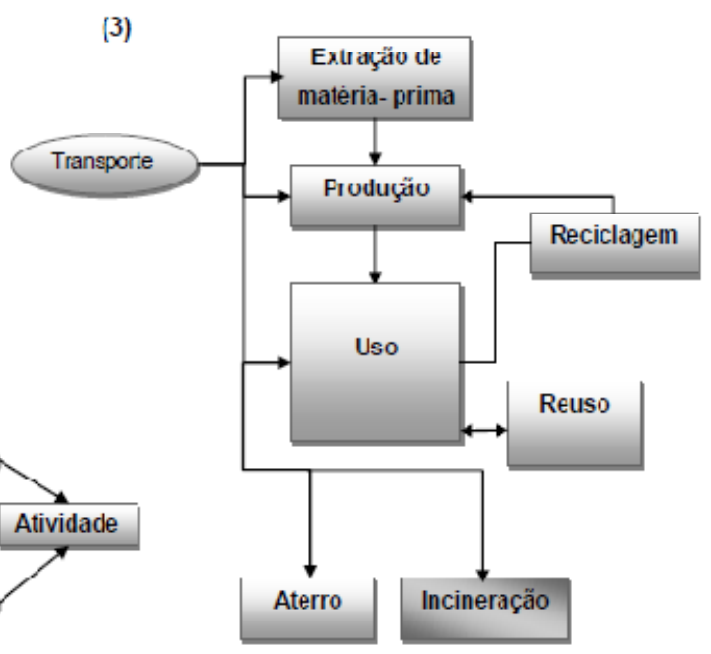

Figura 5.5 - Tipos de pacotes de software de ACV. (1) ACV qualitativa, utiliza estimativas robustas de fornecedores e de dados de transporte. (2) ACV de contabilidade específica adiciona partes da cadeia de um produto em uma estrutura de árvore. (3) ACV completa permite o uso de uma rede de trabalho e fluxos de reciclagem (modificado a partir de TILMANN \& BAUMANN, 2004).

Por outro lado, o pacote de dados do software de ACV de contabilidade específica (Accounting Type LCA) permite avaliações transparentes, isto é, que 
podem ser revisadas por uma terceira parte. É comumente utilizada para a rotulagem e declarações ambientais (por exemplo, Umberto 3.5 e EDIP 2.11 beta $^{17}$ ). Por fim, o do tipo ACV completa (Fullblow) inclui fluxos da rede de trabalho e ciclos de reciclagem. O software apresenta uma extensiva capacidade matemática e envolve uma modelagem mais abrangente do sistema, quando comparada aos outros dois modelos citados anteriormente (GaBi 3, Gabi 4).

Conforme Tilmann \& Baumann (2004), praticamente todos os pacotes de softwares estão em conformidade com os padrões da ISO 14040. Muitos incluem, como parte integrante da ferramenta, um ou diversos métodos de contabilidade, bem como um banco de dados e processos que são comumente utilizados, como, por exemplo, na extração de matérias primas ou na produção de uma vasta quantidade de produção de compostos químicos.

O software escolhido para esse estudo foi o $\mathrm{GaBi} 4^{18}$. Este se caracteriza por propiciar uma ACV "fullblow". Ou seja, uma compreensiva avaliação técnica, econômica e de impactos ambientais de produtos, serviços e sistemas, cujo procedimento para realizar os balanços ecológicos está padronizado de acordo com a norma ISO. Originalmente desenvolvido pelo Institute for Polymer Testing and Polymer Science da Universidade de Sttugart (em cooperação com a PE Europe $\mathrm{GmbH}$ ), o GaBi 4 configura-se, atualmente, em um dos principais software utilizados em estudos de ACV (Figura 5.6).

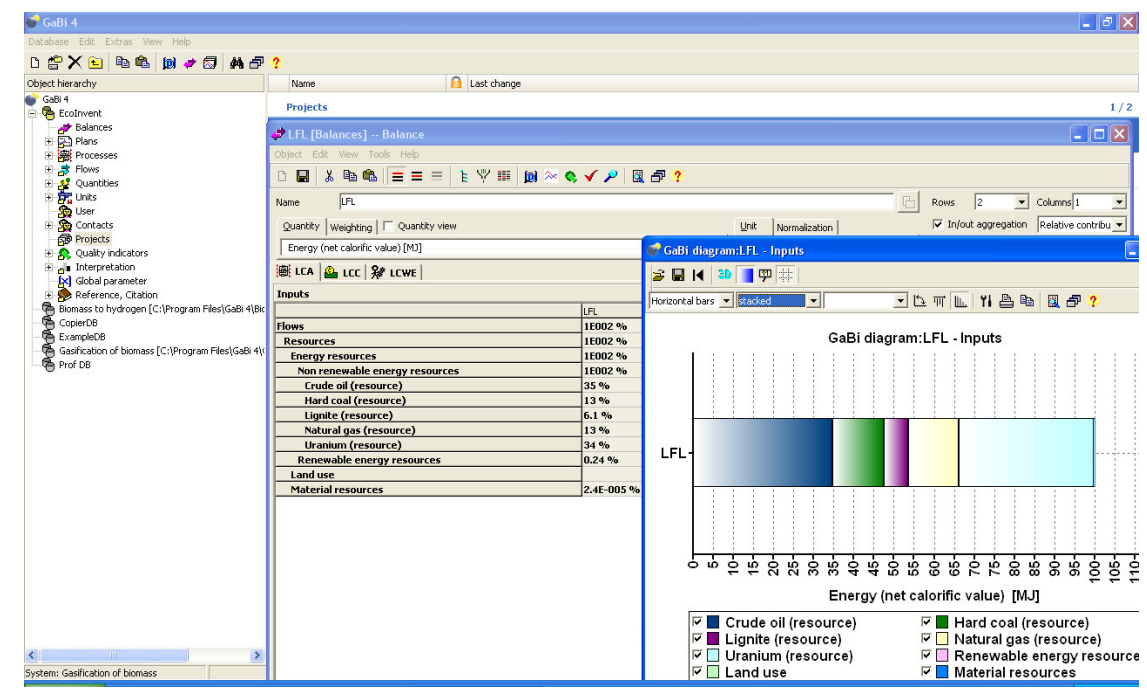

Figura 5.6 - Software de Avaliação do Ciclo de Vida - GaBi 4

\footnotetext{
17 Estes softwares também permitem uma ACV fullblow

18 Disponibilizado durante o doutorado sanduíche na UC Merced e posteriormente pelo IPEN.
} 
METODOLOGIA

O GaBi 4 providencia o suporte necessário para gerenciar uma grande quantidade de um conjunto de dados e modelar ciclos de vida de produtos. Sua funcionalidade permite calcular diferentes tipos de balanços, analisar e interpretar os resultados do ciclo de vida.

Os conjuntos de dados do software incluem as áreas decisivas de cadeias produtivas de metais (aço, alumínio e metais não-ferrosos), de orgânicos e não orgânicos, de materiais sintéticos e minerais, de fornecimento de energia (vapor de água, energia térmica, centrais elétricas), de disposição final, incluindo a reciclagem. Estes bancos de dados são modulares e pré-definidos de acordo com a versão escolhida (professional, lean, student).

O software utilizado também disponibiliza um módulo de métodos de avaliação de impactos ${ }^{19}$, inclusive a utilizada neste estudo, bem como àqueles relacionados à análise energética. Além de auxiliar na modelagem do AICV, é possível realizar a análise de normalização, ponderação e de sensibilidade dos resultados alcançados na avaliação de impacto.

Cabe ressaltar que a maioria dos programas de ACV é disponibilizada apenas na versão em inglês, alguns também incluem versões de comunicação em alemão, japonês ou francês. No caso do GaBi 4, embora haja a disponibilidade de trabalhar com as ferramentas do software em português, a modelagem do sistema bem como os seus resultados são apresentados em inglês.

Desta forma, foram mantidas as siglas em inglês dos parâmetros estudados na avaliação ambiental e na análise do balanço energético. Isto se justifica, por um lado, pelo fato das mesmas serem reconhecidas e utilizadas por especialistas da área no Brasil e no exterior. E por outro, para facilitar a rápida compreensão dos dados nos softwares de ACV e/ou aplicação destas ferramentas de análise.

\subsection{Metodologia de Avaliação de Impactos Ambientais}

A avaliação de impactos do ciclo de vida significa essencialmente compreender os resultados da fase do inventário. Até os dias atuais, muitas metodologias foram sugeridas e descritas. Estas metodologias podem ser divididas

\footnotetext{
19 As metodologias de AICV disponíveis no GaBi 4 são CML1996, CML2001, Eco-indicator 95, Eco-indicator 95 -RF, Eco-indicator 99, EDIP 1997, EDIP 2003, Impact 2002+, Method of Ecological Scarcity (UBP Method) e TRACI.
} 
em métodos orientados para determinados temas (por exemplo, pegada ecológica) e métodos orientados para os danos (por exemplo, avaliação de riscos). A primeira categoria converte os resultados em um número de temas (HEIJUNGS et. al., 1992; HAUSCHILD et. al., 1998), o segundo tipo modela os danos causados pelos resultados do inventário.

Para a avaliação de impactos, o método escolhido foi o do Eco-indicador 99 (El99), que tem se destacado em estudos da ACV de sistemas energéticos renováveis e no uso interno em empresas. Este método é orientado para identificação, caracterização e quantificação dos danos. Os resultados da avaliação são apresentados em um formato simples (agregados em um índice unidimensional $)^{20}$ que permite aos engenheiros e projetistas trabalharem com as informações ambientais no desenvolvimento de projeto ou reprojeto de produtos.

Embora, existam diversos e diferentes conceitos que descrevam o papel dos ecossistemas na sociedade, no nível mais fundamental estes estão inteiramente relacionados com a base da existência humana. Isto é, danos causados ao meio ambiente são considerados ameaças diretas à humanidade. Este conceito é comumente referenciado como o princípio da sustentabilidade, no qual se almeja um desenvolvimento que suporte a vida humana na terra atual, no médio e longo prazo.

Segundo Goedkoop \& Spriensma, 2001, no El 99, todas as emissões, extrações e uso do solo, que podem ocorrer durante o ciclo de vida do produto, são expressos em três parâmetros independentes e envolvem os seguintes preceitos:

I. Saúde Humana (SH): todo ser humano, no presente e futuro, deve viver em um ambiente livre de doenças transmissíveis, deficiências ou mortes prematuras.

II. Qualidade do Ecossistema (QE): as espécies não humanas não devem sofrer distúrbios que provoque mudanças nas suas populações ou na sua distribuição geográfica.

III. Recursos Minerais e Combustíveis fósseis (RMCF): o ambiente natural, fornecedor de recursos essenciais para a sociedade, deve estar disponível também para as futuras gerações.

\footnotetext{
${ }^{20}$ Nussbaumner (2004) relata que resultados propiciados por este método tem importante valor para a avaliação genérica de diferentes tecnologias.
} 
Para estabelecer a relação entre os dados do inventário e os potenciais danos, o El 99 utiliza quatro diferentes procedimentos sequenciais, a saber: i) análise dos recursos, do uso da terra e da probabilidade; ii) análise da exposição e dos efeitos; iii) análise dos danos e iv) normalização e ponderação. A figura 5.7 apresenta os diferentes procedimentos e os seus resultados.

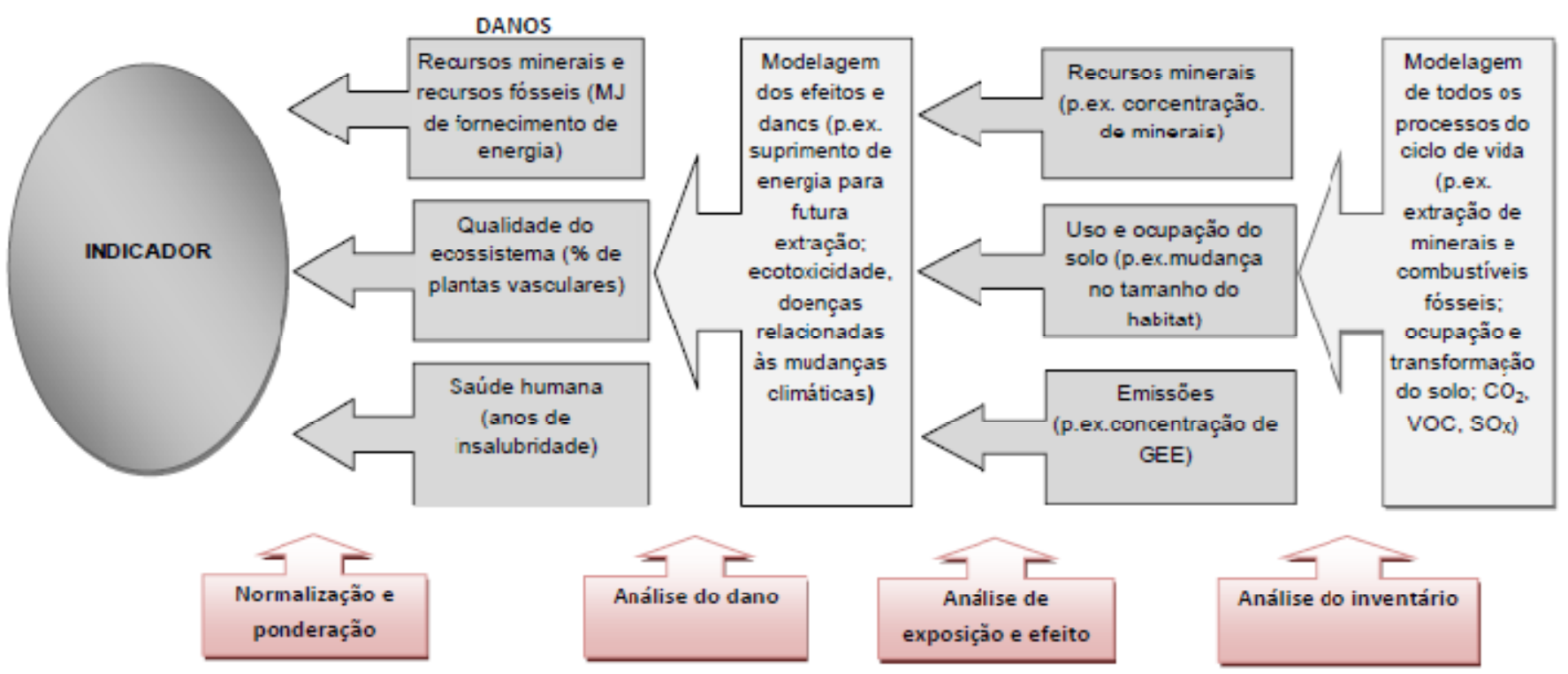

Figura 5.7 - Estrutura conceitual da metodologia do Eco-indicator 99 (modificado a partir de GOEDKOOP \& SPRIENSMA, 2001).

Nas etapas sequenciais mencionadas acima, cada parâmetro, por sua vez, apresenta procedimentos de cálculos e resultados intermediários distintos. Uma vez que a metodologia do El 99 abrange uma série de outros conceitos e métodos para modelar cada dano, a seção a seguir apresenta uma descrição sucinta dos três parâmetros - SH, QE e RMCF e os estágios de análise, bem como os conceitos básicos envolvidos para efetuar a avaliação. Para um aprofundamento sobre o assunto (dados operacionais, fontes e modelagem das incertezas), as referências aqui citadas e, principalmente, o relatório metodológico desenvolvido por Goedkoop \& Spriensma (2001) devem ser consultados.

\subsubsection{Categoria de Danos: Saúde Humana}

A saúde de qualquer indivíduo humano, membro da presente ou de uma futura geração, pode ser ameaçada tanto pela redução dos anos de vida, quanto pela morte prematura ou, por uma temporária ou permanente redução das capacidades do corpo humano (deficiências/desabilidades). 
De acordo com Goedkoop \& Spriensma (2001), os danos à saúde humana causados por fontes ambientais são principalmente: i) doenças infecciosas, cardiorrespiratórias e respiratórias, bem como o deslocamento da população devido às mudanças climáticas; ii) câncer resultante de radiação ionizante; iii) câncer e danos aos olhos devido à depleção da camada de ozônio; iv) doenças respiratórias e câncer devido a compostos químicos tóxicos; no ar, água ou alimentos.

Tais danos, decorrentes de emissões de sistemas produtivos, são os mais importantes relacionados à saúde humana. No El 99, os danos à saúde humana são apresentados em 6 (seis) categorias ( parâmetros):

I. Efeitos carcinogênicos: esta categoria utiliza a classificação dada pela Agência Internacional de Pesquisa em Cancer - International Agency for Research on Cancer (IARC) para relacionar uma evidência disponível de um grupo de substâncias químicas a carcinogenicidade humana ou animal ${ }^{21}$.

II. Mudanças climáticas: esta categoria utiliza dois modelos para relacionar os danos (migração, perda de áreas secas e áreas úmidas, malária, ciclone tropical e extra-tropical, deslocamento da população, entre outros) às mudanças climáticas à saúde humana. $O$ primeiro é o FUND 1.6, que calcula o dano total em função da concentração de $\mathrm{CO}_{2}$, o segundo é o ExternE, adaptado para calcular os danos marginais (como por exemplo, malária, esquistossomose, entre outros).

III. Depleção da camada de ozônio: esta categoria relaciona a depleção da camada de ozônio, devido ao aumento da concentração de substancias derivadas do CFC's (cloretos e brometos), á danos a saúde humana (tais como câncer da pele e catarata).

IV. Radiação ionizante: esta categoria relaciona emissões rotineiras de material radioativo para o meio ambiente aos danos a saúde humana (câncer não fatal e fatal, entre outros). Nesta categoria não são considerados os efeitos à saúde relacionados a emissões acidentais e devido à exposição ocupacional

\footnotetext{
21 O dano, resultante das emissões do sistema produtivo, é calculado para todas as substâncias classificadas no IARC nos quais há suficiente informação disponível das características físicas, químicas e de carcinogênese.
} 
V. Efeitos respiratórios inorgânicos e (VI) orgânicos: estas duas categorias relacionam, com base em estudos epidemiológicos, diversas substâncias não orgânicas e orgânicas a efeitos respiratórios. Segundo Pilkington et. al. (1997), os efeitos respiratórios são causados pelas seguintes substâncias: materiais particulados $\left(\mathrm{PM}_{10}\right.$ e $\left.\mathrm{PM}_{23}\right)$, nitretos e sulfetos, $\mathrm{SO}_{3}, \mathrm{O}_{3}, \mathrm{CO}$ e similares, $\mathrm{NO}_{x}$.

Para agregar os diferentes tipos de danos à SH (doenças) utiliza-se a escala DALY (Disability Adjusted Life Years), desenvolvido por Murray et. al. (1996). O sistema DALY é uma escala de pesos, no qual 0 (zero) representa perfeitamente saudável e 1 (um) morto ${ }^{22}$. Quatro procedimentos são utilizados para a modelagem dos danos à saúde humana:

I. Na análise de probabilidade, as emissões (expressa em massa) são relacionadas a uma mudança temporária na sua concentração,

II. $\mathrm{Na}$ análise de exposição, as mudanças temporárias são relacionadas a uma dose;

III. Na análise de efeitos, as doses são relacionadas a um número de efeitos (doenças), tais como câncer e efeitos respiratórios.

IV. Na análise do dano, os efeitos à saúde são relacionados com um número de anos de perda de capacidade e/ou número de anos de vida perdidos.

Destarte, a unidade de medida para esta categoria é o DALY, expresso em anos de vida perdidos, devido a perda da saúde ou morte prematura, tal como utilizado pela World Heath Organization (WHO - Organização Mundial da Saúde).

\subsubsection{Categorias de Danos: Qualidade do Ecossistema}

Os ecossistemas são muito complexos e é muito difícil determinar todos os danos sofridos. Diferente da saúde humana, dificilmente é possível direcionar a atenção para cada espécie de planta ou animal. Neste sentido, o El 99 utiliza a

\footnotetext{
22 Aplicações do uso do DALY em ACV, bem como os dados para os efeitos respiratórios e cancerígenos, devida a emissões de compostos químicos, são providenciados no estudo de Hofstetter (1998), o qual também estudou os efeitos das mudanças climáticas à SH. No que tange aos efeitos das radiações ionizantes, os dados são encontrados em Frischknecht et. al (1999).
} 
diversidade de espécies como indicador deste dano. Para quantificá-lo, quatro outros parâmetros são utilizados: ecotoxicidade, acidificação e eutrofização, conversão e uso do solo.

\section{Ecotoxidade}

Para este parâmetro, o El 99 utiliza o método recentemente desenvolvido para o Dutch Environmental Outlook (MEENT \& KLEPPER, 1997). Este método determina a Fração Potencialmente Afetada - Potentially Affected Fraction (PAF) de espécies $(s p)$ em relação à concentração de substâncias tóxicas. A figura $\mathbf{5 . 8}$ apresenta a curva do PAF, expressando a fração potencialmente afetada pela exposição a uma dada substancia tóxica.

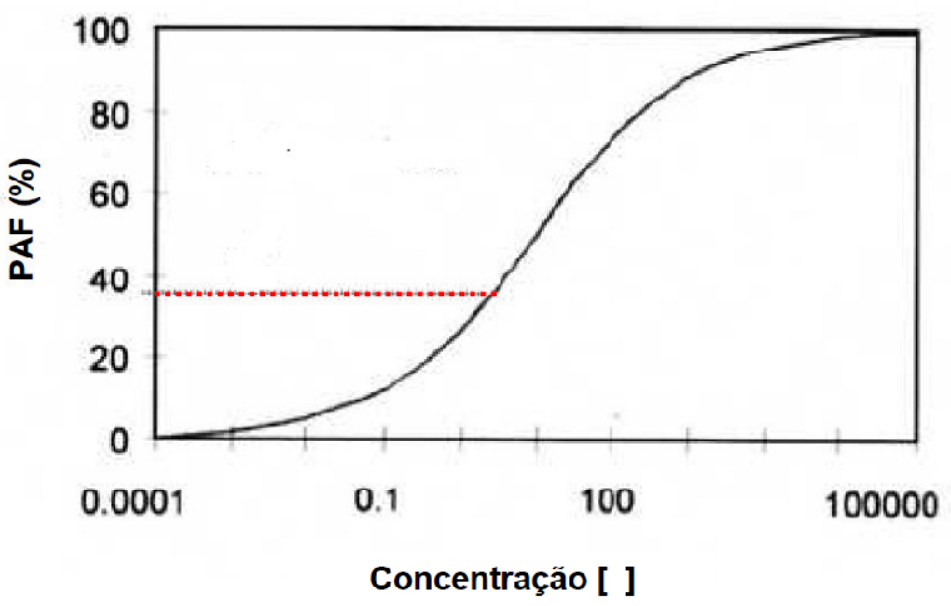

Figura 5.8 Exemplo da curva do PAF em função da exposição de uma dada sp a determinadas concentrações (modificado a partir de GOEDKOOP \& SPRIENSMA, 2001).

Os PAFs são determinados com base nos dados de toxicidade para os organismos terrestres e aquáticos, tais como algas, crustáceos, peixes, entre outros. Esta medida expressa a porcentagem de $s p$ expostas a uma concentração acima do Efeito de Concentração Não Observado - No Observed Effect Concentraction (NOEC). Quanto maior a concentração, maior será o número de sp afetadas.

Tendo em vista que o PAF, baseado no NOEC, não necessariamente produz um dano observável (desaparecimento ou extinção), nem mesmo quando os valores de PAF são de $50 \%$ ou $90 \%$. Esta medida é interpretada como estresse tóxico e não como uma medida para modelar o desaparecimento ou extinção de espécies (MEENT \& KLEPPER, loc. cit). 


\section{Acidificação e eutrofização}

Para a acidificação e eutrofização, não é possível utilizar o conceito da PAF diretamente, visto que os danos oriundos destes dois parâmetros são causados por mecanismo bioquímicos inteiramente diferentes e complexos. No entanto, a partir dos efeitos observáveis da acidificação e eutrofização, a probabilidade de $s p$ de plantas que ainda ocorrem em uma determinada área podem ser determinadas. Esta probabilidade é denominada como Probabilidade de Ocorrência - Probability of Ocurrence (POO) (WEIRTZ et. al , 1992) a qual, no El 99, é nomeada como Fração Potencialmente Desaparecida - Potentially Disappeared Fraction (PDF), onde:

$$
\mathrm{PDF}=1-\mathrm{POO}
$$

O modelo computacional Natuur Planner desenvolvido pelo RIVM (GOEDKOOP \& SPRIENSMA, 2001) é usado tanto para a modelagem da probabilidade, quanto para a modelagem dos danos para a deposição de $\mathrm{NO}_{x}, \mathrm{SO}_{x} \mathrm{e}$ $\mathrm{NH}_{3}$. Este modelo utiliza um detalhado conjunto de $s p$ indicadoras (que ocorrem em um específico ambiente, no qual não há mudanças nos níveis de nutrientes e acidez provocados por atividades antrópicas), e o tipo de ecossistemas associados a estas $s p$. A modelagem do dano calcula qual a extensão do número de $s p$ indicadoras que aumentam ou diminuem se uma deposição adicional é acrescida ao ambiente.

\section{Uso e conversão do solo}

Para o uso da terra, o El 99 também utiliza a PDF como indicador. Entretanto, neste caso, as $s p$ indicadores não foram consideradas para todos os organismos. A modelagem dos danos é ainda mais complexa e para tanto, são utilizados quadro diferentes modelos: i) o efeito local da ocupação do solo; ii) o efeito local da conversão do solo; iii) o efeito regional da ocupação do solo e iv) o efeito regional da conversão do solo.

Os efeitos locais referem-se às mudanças no número de ocorrências de $s p$ de um solo ocupado e convertido, enquanto os efeitos regionais se referem às alterações de áreas naturais fora das áreas ocupadas ou convertidas. Os efeitos regionais foram inicialmente descritos por Muller-Wenk (1998). Os dados para um número de $s p$ por tipo e uso do solo e alguns dos conceitos utilizados para descrever os efeitos locais são baseados em Kollner (1999). 
Para converter os resultados obtidos em cada parâmetro, mencionado acima, no dano à qualidade dos ecossistemas, duas diferentes abordagens são utilizadas na modelagem:

A. Emissões tóxicas e emissões que alteram os níveis de acidez e nutrientes seguem o procedimento abaixo:

i. Análise de probabilidade: relaciona as emissões a concentrações de substâncias ( $\left.\mathrm{kg} / \mathrm{m}^{2} / \mathrm{ano}\right)$;

ii. Análise de efeito: as concentrações são relacionadas ao estresse tóxico ou aumento dos níveis de nutrientes ou acidez;

iii. Análise do dano: estes efeitos são relacionados um potencial aumento da fração de $s p$ de plantas desaparecidas e/ou extintas.

B. O uso da terra e transformação do solo é modelado com base nos dados empíricos de qualidade do ecossistema, em função do tipo de uso e do tamanho da área.

Desta forma, a unidade de medida da categoria de dano QE é dada pelo decréscimo das espécies de uma determinada área e durante um período de tempo, a saber:

$$
\mathrm{QE}=\mathrm{PDF} \text {. tempo.área }\left(\mathrm{m}^{2} / \mathrm{ano}\right)
$$

\subsubsection{Categoria de Danos: Recursos Minerais e Combustíveis Fósseis}

No El 99 somente os minerais e combustíveis fósseis são modelados. O uso de recursos bióticos da agricultura e da silvicultura, bem como a mineração de recursos, como por exemplo, a areia, são considerados adequadamente cobertos pela análise do efeito do uso do solo ${ }^{23}$. Recursos bióticos extraídos diretamente da natureza, como peixe e plantas silvestres, não são modelados no El 99.

O conceito do dano, utilizado no El 99, foi elaborado a partir do estudo desenvolvido por Chapman \& Roberts (1993). Estes autores desenvolveram um procedimento de avaliação para severa depleção de recursos, baseados na energia necessária para extrair um mineral em relação à sua concentração. Por este motivo,

\footnotetext{
${ }^{23}$ Por definição, os recursos parcialmente se sobrepõem com outras categorias de danos, particularmente no que se refere à qualidade dos ecossistemas. Por exemplo, a disponibilidade de água e ar limpo, bem como a biodiversidade, são cobertas por outras categorias de danos.
} 
- El 99 não considera a quantidade de um dado recurso, mas a qualidade da estrutura do mesmo, no qual o decréscimo da concentração do recurso é a base da análise.

Segundo Goedkoop \& Spriensma (2001), embora seja evidente que os recursos não renováveis avaliados nesta categoria (minerais e combustíveis fósseis) sejam limitados, é arbitrário fixar limites convincentes para incluir ou não incluir a ocorrência de reservas acessíveis. Se contabilizarmos as reservas facilmente acessíveis (ou de alta concentração), as quantidades serão bem menores em comparação às atuais extrações. Se incluirmos as ocorrências de difícil exploração (ou de baixa concentração), a quantidade do recurso se tornará enorme.

Por outro lado, as forças do mercado asseguram que as reservas com alta concentração de um dado recurso sejam as primeiras a serem exploradas, deixando que as futuras gerações lidem com as reservas de baixa concentração. Portanto, em teoria, a quantidade de minerais disponíveis para as futuras gerações irá diminuir com a extração de cada quilo, enquanto os esforços (demanda de energia) para a sua extração irão aumentar (GOEDKOOP \& SPRIENSMA, op. cit).

Neste sentido, o dano é modelado em função da energia necessária para extrair um kg de mineral no futuro, no qual o conceito de suprimento de energia é utilizado tanto para os minerais, quanto os combustíveis fósseis. Para calcular os danos aos recursos, esta análise segue dois procedimentos:

I. Análise dos recursos: análoga à análise de probabilidade, esta etapa relaciona a extração de um recurso ao decréscimo da concentração do mesmo;

II. Análise de dano: relaciona a baixa concentração ao aumento dos esforços (demanda de energia) em extrair os recursos no futuro.

A unidade de medida desta categoria é expressa pelo suprimento de energia em MJ por kg de material extraído. Este valor é a expectativa de aumento de consumo de energia para cada kg de um dado material extraído. 


\subsubsection{Normalização}

Todas as três categorias de danos tem diferentes unidades. Neste caso, para avaliação da magnitude de cada dano a uma dada referência ${ }^{24}$, utiliza-se um conjunto de fatores adimensionais para converter os valores de cada categoria em adimensionais.

Desta forma, como o El 99 foi desenvolvido na Europa, os fatores de conversão são baseados nos valores de normalização europeus ${ }^{25}$. O procedimento de normalização do El 99 é determinado pela contribuição relativa dos danos calculados para um total de danos causados a um sistema de referência. Usualmente, o sistema de referência é o conjunto de todas as emissões e extrações no mundo ou em uma específica localidade, durante certo tempo.

\subsubsection{Ponderação}

Nesta etapa, os resultados obtidos nos parâmetros analisados dentre as diferentes categorias de impacto, são convertidos e agregados, utilizando-se fatores numéricos baseados em uma escolha de valores. Uma particularidade do método de avaliação do Eco-indicador 99 é o uso da Teoria Cultural (TOMPSON et. al.,1990 apud GOEDKOOP \& SPRIENSMA, 2001) para avaliar os danos, uma vez que a mesma também depende da percepção dos riscos e envolve escolhas, na sua maioria subjetivas.

Desta forma, há três diferentes conjuntos de escolhas de valores ou três versões (arquétipos) de modelagem dos danos, nomeadamente: i) igualitário; ii) individualista e iii) hieraquista (Tabela 5.1).

A versão igualitária utiliza o "Princípio da Precaução" e não aceita que futuros problemas possam ser evitados, enquanto o arquétipo individualista considera que os limites em relação aos danos não são negociáveis até que suficiente prova seja dada. Por outro lado, o modelo hierarquista considera fatos que possuem suficiente respaldo e reconhecimento científico e político

\footnotetext{
24 A norma NBR ISO 14044 (2009) indica como exemplos de valores de referência, as entradas e as saídas para uma dada área (global, regional e local), valores com base em per capita ou um cenário de linha -base. Outros exemplos, como padrões de qualidade de ar, água e solo podem ser utilizados.

25 Blonk et. al (1997) descrevem os valores de normalização da área geográfica europeia, bem como o total de consumo por média de consumidores. Em cada caso, o período é um ano e os resultados são divididos pelo número de habitantes da região.
} 
Tabela 5.1 - Exemplo de valores típicos das três perspectivas de análise do Ecoindicator 99 (modificado a partir de GOEDKOOP \& SPRIENSMA, 2001).

\begin{tabular}{cccc}
\hline Arquétipo & Igualitário & Individualista & Hieraquista \\
\hline Critério & Argumento & Experiência & Evidência \\
\hline Perfil de gerenciamento & Preventivo & Adaptativo & Controle \\
Distribuição & Paridade & Prieridade & Balanço distinto entre curto e \\
longo prazo
\end{tabular}

No presente estudo, o modelo considerado foi o hierarquista, uma vez que tal posicionamento é o mais comum na comunidade científica e dentre os legisladores. Um exemplo típico é a ampla aceitação das linhas guia do Intergovernamental Panel Climate Change para as mudanças climáticas.

Neste sentido, os resultados obtidos na avaliação de cada parâmetro (por exemplo, ecotoxicidade, eutrofização) das diferentes categorias de danos (SH, QE, RMCF), são normalizados, combinados com os valores de ponderação (atribuição de pesos) dada pelo modelo hierarquista.

Cabe ressaltar que no El 99 cada substância e atividade apresenta um fator de dano, normalização e ponderação específico. A tabela 5.2 apresenta a média ${ }^{26}$ dos fatores de normalização e de ponderação, utilizados neste estudo.

Tabela 5.2 - Média dos fatores de danos, normalização e ponderação na perspectiva hieraquista (Cf. GOEDKOOP \& SPRIENSMA, 2001)

\begin{tabular}{ccc}
\hline Categoria de dano & Normalizaçäo & Ponderaçäo \\
\hline Saúde Humana & $1,54 \mathrm{E}-02$ & 0,4 \\
Qualidade dos Ecossistemas & $5,13 \mathrm{E}+03$ & 0,4 \\
Recursos e Combustivieis Fósseis & $8,41 \mathrm{E}+03$ & 0,2 \\
\hline
\end{tabular}

Desta forma, na avaliação de impacto do ciclo de vida dos sistemas aqui estudados, os resultados finais (obtidos após a etapa de normalização e

26 Esta media é dada pelo EI 99 com base nos valores (fator de normalização e fator de ponderação) de cada substância química e outros parâmetros de inventário, listados na maioria dos mais populares banco de dados de ACV. Mais de 1000 substâncias encontram-se listadas no EI-99. 
ponderação) são apresentados conforme a sua contribuição relativa e o valor agregado na sua respectiva categoria de dano (Tabela 5.3).

\begin{tabular}{lcc}
\hline \multicolumn{1}{c}{ Eco-indicador 99 } & Contribuição relativa (\%) & Valor agregado (\%) \\
QE - Acidificação/Eutrofização & 5,00 & \\
QE - Ecotoxicidade & 5,00 & \\
QE - Conversão do solo & 0,00 & 10,00 \\
QE - Uso do Solo & 0,00 & \\
SH - Efeitos carcinogênicos & 0,00 & \\
SH - Mudanças climáticas & 20,00 & \\
SH - Depleção da camada de ozônio & 0,00 & 40,00 \\
SH - Radiação ionizante & 20,00 & \\
SH - Efeitos respiratórios (inorgânicos) & 0,00 & \\
SH- Efeitos respiratórios (orgânicos) & 0,00 & \\
RMCF - Combustiveis fósseis & 30,00 & 50,00 \\
RMCF - Recursos minerais & 20,00 & 100 \\
Total & 100 & \\
\hline
\end{tabular}

Tabela 5.3 - Exemplo dos resultados da AICV com suas respectivas contribuições relativas e valores agregados (FUKUROZAKI, 2011).

Para comparar o perfil ambiental de dois produtos alternativos, utilizou-se a ferrramenta do Triângulo, conhecida como Triangle Tool disponibilizado pela PréConsultants $^{27}$ (Figura 5.9).

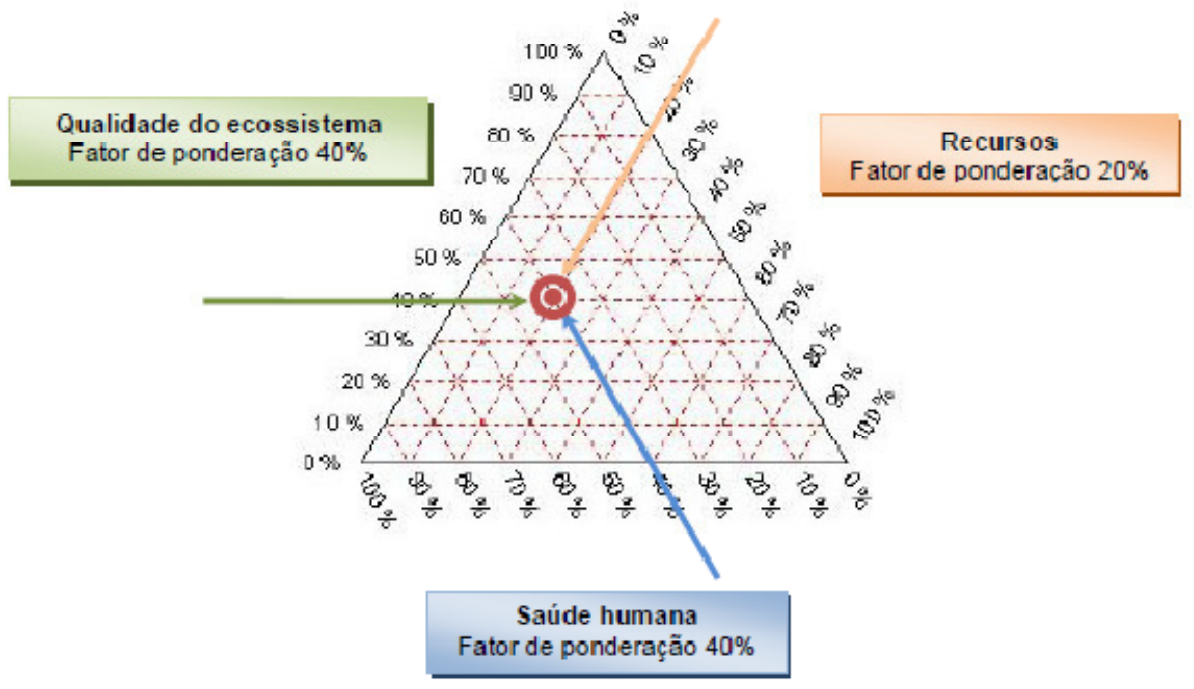

Figura 5.9 - Triangle tool . O ponto marcado no triangulo está posicionado onde a SH é ponderado em $40 \%$, a QE em $40 \%$ e os recursos em $20 \%$. O ponto é definido pelo valor dado em cada lado do triângulo, de onde as setas partem em direção ao ponto de encontro dentro do triângulo ( baseado em HOFSTETTER, 1998).

Esta ferramenta é útil para ilustrar o resultado da ponderação de cada categoria de um dado produto e comparar os resultados entre dois produtos

${ }^{27}$ Disponível para download no site http:// www.pre-consultants.com 
alternativos. Cada lado do triângulo representa as contribuições relativas (em um total de $100 \%$ ) do dano à saúde humana, à qualidade do ecossistema e aos recursos minerais e de combustíveis fósseis.

Um importante atributo desta ferramenta é a possibilidade de delinear linhas de indiferença (Figura 5.8).

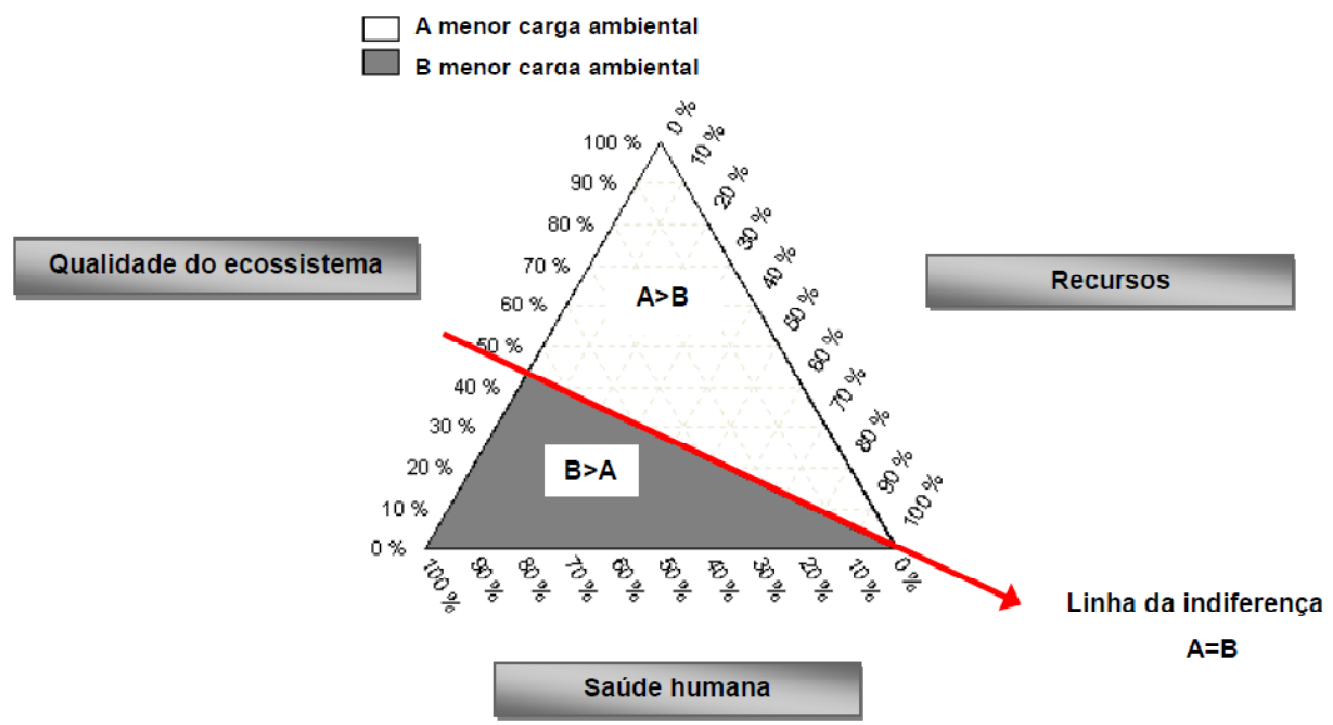

Figura 5.10 - Linha de indiferença dentro do Triangle tool e as sub áreas. Onde A>B significa que a alternativa $A$ é ambientalmente superior do que $B$ e o eco-índice de $B$ é maior do que $A$ ( baseado em GOEDKOOP \& SPRIENSMA, 2001 ).

Estas linhas representam os fatores ponderados, onde o produto A e produto $B$ tem a mesma carga ambiental. A linha de indiferença divide o triângulo em áreas de ponderação no qual o produto $A$ é mais favorável que o $B$ e vice-versa.

\subsection{Interpretações dos resultados}

.A interpretação corresponde à etapa da ACV, na qual os resultados dos parâmetros estudados e obtidos após os cálculos do inventário e da avaliação de impactos são refinados (em função do objetivo e escopo do estudo) no sentido de se obter conclusões e recomendações (Cf. NBR ISO 14044, 2009).

Há diferentes caminhos para a realização desta etapa da ACV e, em princípio, há dois tipos de análises: i) identificação das questões significantes e; ii) confiabilidade dos resultados ( TILMANN \& BAUMANN, 2004). 
No primeiro tipo, a análise pode ser conduzida de forma a identificar os estágios do ciclo de vida que produzem, por exemplo, mais poluentes, as questões metodológicas críticas, entre outros. Enquanto o segundo tipo, a análise visa estabelecer a confidência dos resultados, tais como análise das incertezas, sensibilidade e qualidade dos dados.

Neste trabalho, o processo de interpretação considerou a análise da identificação das questões significantes (por exemplo, perfil de impacto e desempenho energético) em função do objetivo e escopo estabelecidos na ACV dos sistemas de gaseificação e de energia solar fotovoltaica. Esta fase é apresentada no capítulo de conclusões e recomendações deste trabalho. 


\section{AVALIAÇÃO DO CICLO DE VIDA DOS SISTEMAS DE GASEIFICAÇÃO E DE ENERGIA SOLAR FOTOVOLTAICA}

Neste capítulo, os resultados alcançados na avaliação do ciclo de vida dos sistemas de gaseificação (leito fixo e leito fluidizado) e da planta de energia solar são relatados e discutidos em três partes sequenciais, que correspondem respectivamente às 03 (três) primeiras etapas metodológicas da ACV, mencionadas no capítulo anterior. Portanto, os resultados de cada etapa analítica dos sistemas energéticos estudados (gaseificação e energia solar fotovoltaica) são apresentados da seguinte forma: i) definição do objetivo, escopo e unidade funcional; ii) análise do inventário (incluindo o balanço energético) e; iii) análise de impactos.

\subsection{SISTEMAS DE GASEIFICAÇÃO}

\subsubsection{Definição do objetivo, escopo e unidade funcional.}

O objetivo da ACV dos sistemas de gaseificação da biomassa é identificar e comparar o desempenho ambiental e o energético de duas plantas de geração de energia de diferentes tecnologias, a saber: gaseificador de leito fixo (LFX) e gaseificador de leito fluidizado (LFL).

Conforme Lora et. al (2008), basicamente uma instalação de gaseificação é constituída pelos seguintes elementos: i) pré-processamento da biomassa (transporte, secagem e cominuição da biomassa), ii) gaseificador; iii) sistema de tratamento do gás (resfriamento e limpeza do gás) e iv) tratamento dos resíduos (disposição adequada). A figura 6.1 apresenta um exemplo simplificado de um sistema de gaseificação de leito fixo e a figura 6.2 de sistema de gaseificação de leito fluidizado.

Tendo em vista a ausência de informações disponíveis para a modelagem da gaseificação da biomassa de origem de resíduos agroindustriais, especificamente o bagaço de cana, optou-se pelo uso da madeira de diferentes origens, incluindo a oriunda de resíduos (discutidos adiante).

A potência definida para as plantas de gaseificação - LFX e LFL modeladas neste estudo, é de $1 \mathrm{MW}$ T cada, o que corresponde a uma alimentação de biomassa em torno de 45,00 a 46,00 $\mathrm{m}^{3} / \mathrm{dia}$ de madeira (base úmida), dependendo da tecnologia (leito fixo ou leito fluidizado). Isto é, cada planta processa cerca de 15 a 
$17 \mathrm{t} /$ dia de madeira e produz um valor líquido de 16.000 a $16.615 \mathrm{Nm}^{3}$ de syngas (330 dias/ano).

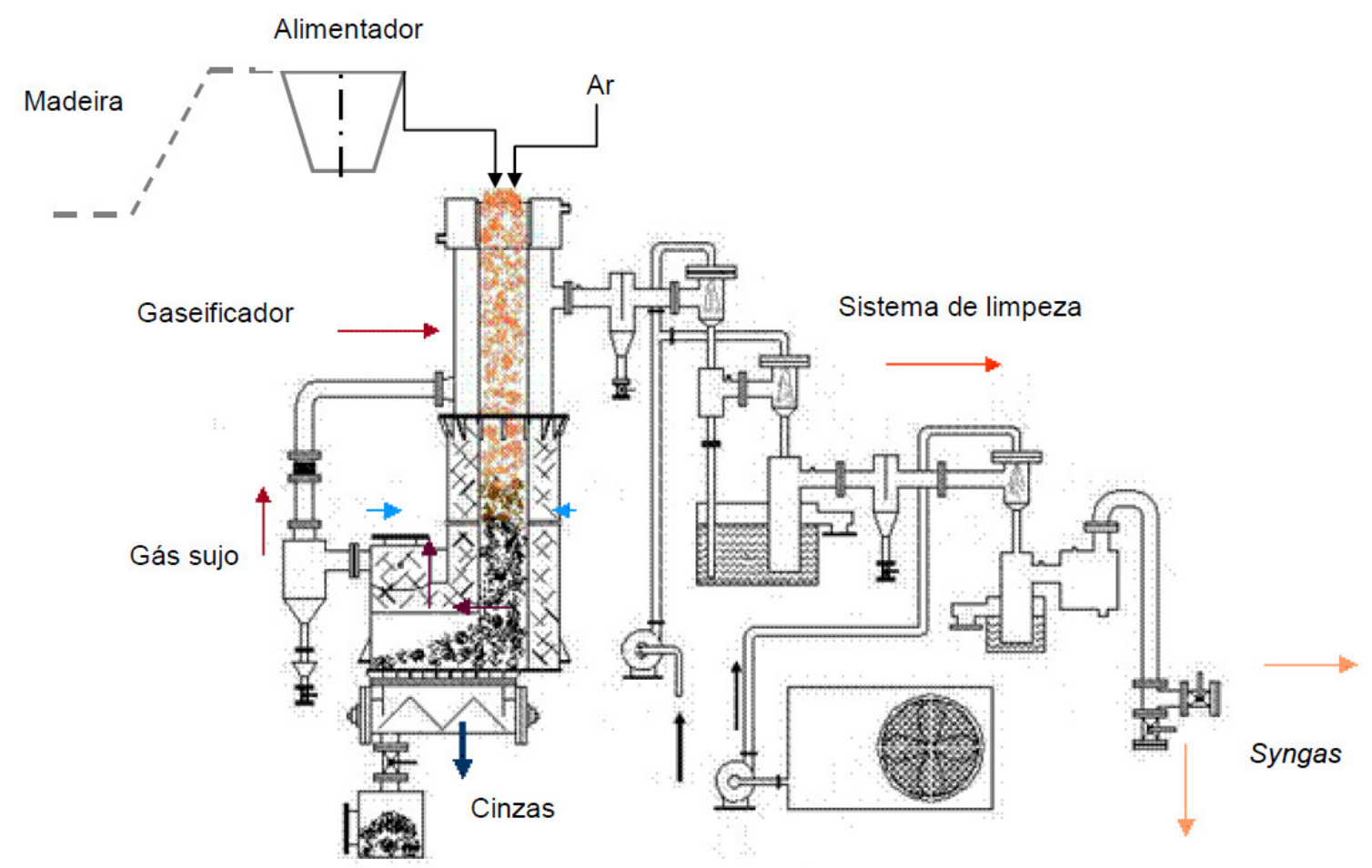

Figura 6.1 - Exemplo de um esquema de instalação de um gaseificador de biomassa leito fixo contracorrente (modificado a partir de USSHIMA, 2003).

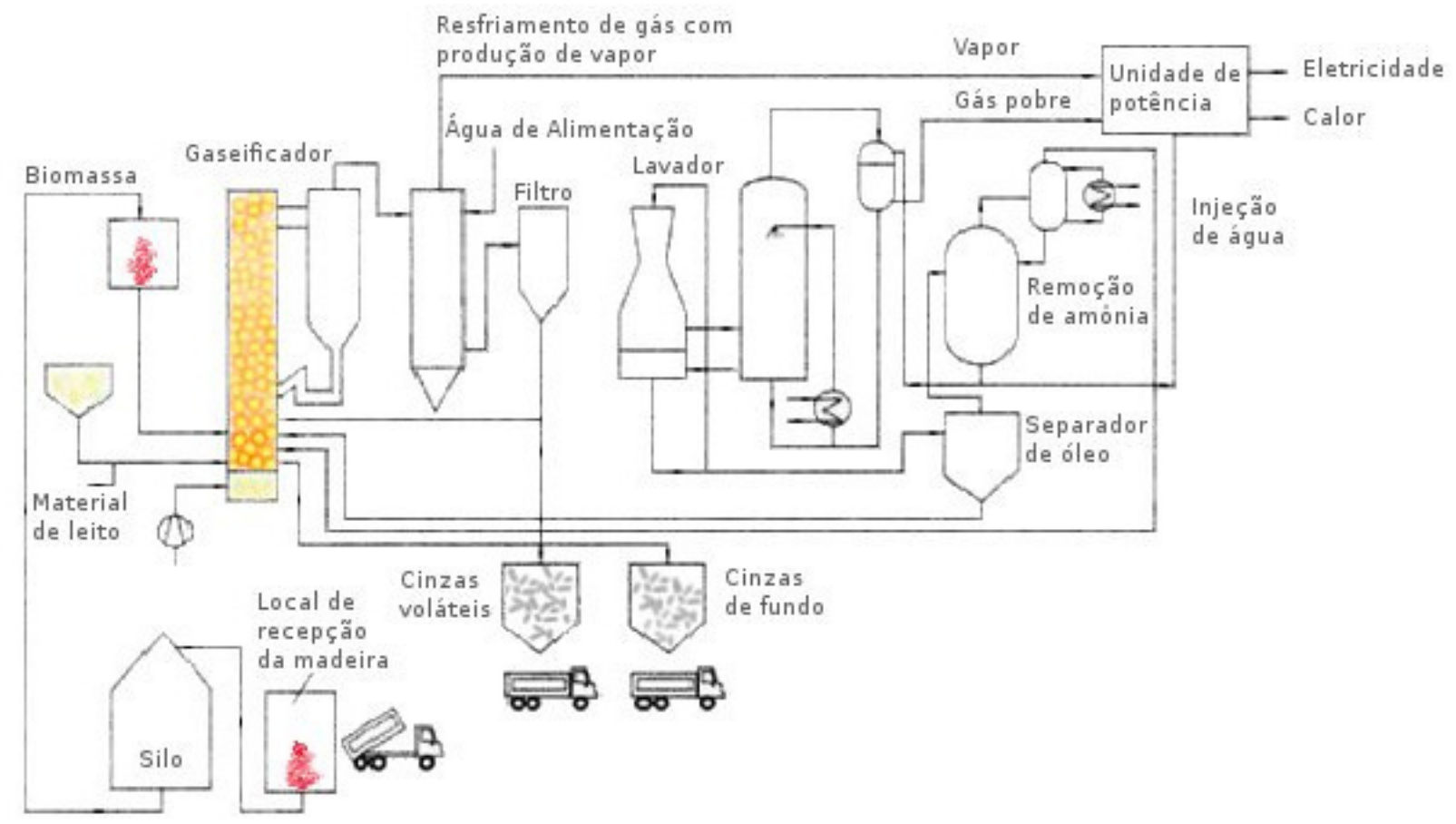

Figura 6.2 - Exemplo de um esquema de instalação de um gaseificador de biomassa leito fluidizado circulante (modificado a partir de LORA et. al, 2008). 
No presente estudo, a ACV dos sistemas de gaseificação não inclui na análise as tecnologias posteriores de utilização do combustível produzido pelos sistemas e suas respectivas eficiências de conversão. Neste sentido, um $M_{T}$ corresponde a $\mathrm{MW}_{\mathrm{El}}$, considerando a energia química $(\mathrm{PCl})$ contida no syngas $\left(\mathrm{MJ} / \mathrm{Nm}^{3}\right)$ e o seu equivalente em energia elétrica $(\mathrm{kWh})$.

Para a condução da ACV e de análises comparativas, a unidade funcional estabelecida para o presente estudo é a capacidade máxima de produção de energia (potência instalada) de $1 \mathrm{MW}_{\mathrm{El}}$, aqui denominada apenas MW. Em síntese, o escopo do estudo incluiu:

I. O transporte da biomassa (madeira) para os locais de pré-tratamento (redução do tamanho e redução da massa de água) de acordo com os requerimentos de cada sistema.

II. Os requerimentos de materiais para infraestrutura e montagem da planta, as estimativas do uso de energia para a construção (neste caso, o diesel utilizado nas máquinas de construção e no consumo de eletricidade on site), descomissionamento e a disposição/reciclagem da planta energética, bem como o uso e a ocupação do solo.

III. O processo de gaseificação, incluindo os processos de remoção de impurezas e contaminantes do syngas (limpeza do gás).

IV. A disposição final dos resíduos gerados durante a utilização da planta, tais como efluentes e resíduos sólidos.

Conforme Dauriat \& Gnansounou (2007), as características do syngas são estritamente dependentes do tipo de biomassa, da tecnologia considerada e dos processos de tratamento pós-gaseificação, estes últimos, por sua vez, são dependentes da finalidade de uso do syngas.

De fato, para a geração de energia em motores de combustão interna ou turbinas a gás, o syngas não possui os mesmos requisitos (valor calorífico, composição e pureza) do que, por exemplo, para a produção de hidrogênio, metanol e diesel Fischer - Tropsch. 
No que tange à produção de hidrogênio, Walter \& Nogueira (2008) recomendam as células a combustível de alta temperatura de operação (SOFC e $\mathrm{MCFC}^{1}$ ) para o acoplamento com gaseificadores da biomassa (Figura 6.3).

Walter \& Nogueira (op. cit., 2008) também indicam que, embora alguns contaminantes presentes no syngas, tais como $\mathrm{NH}_{3}$ e $\mathrm{H}_{2} \mathrm{~S}$, afetem o desempenho da SOFC, não existem ainda dados concretos disponíveis sobre os níveis de tolerância para outros contaminantes.

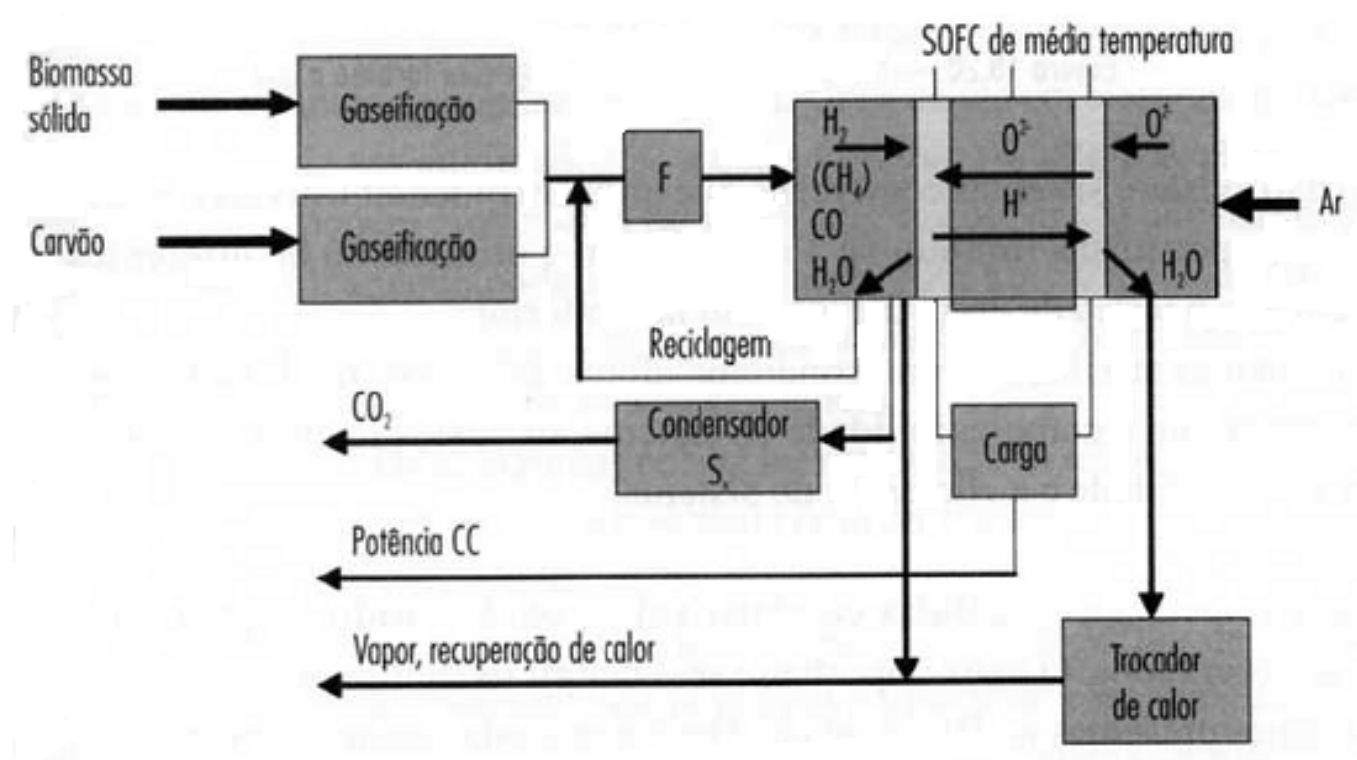

\section{$\mathrm{F}$ : Combustiveis sintéticos: $\mathrm{H}_{2}+\mathrm{CnHm}$}

Figura 6.3 - Diagrama esquemático de uma célula SOFC operando com um gaseificador de biomassa (WALTER \& NOGUEIRA, 2008).

Neste sentido, tendo como pressuposto que a futura aplicação do syngas, produzido em ambos os sistemas, está direcionado principalmente para o uso direto em células de alta temperatura, e considerando também a possibilidade de utilização para a produção de hidrogênio puro e outros vetores energéticos, a produção do syngas foi mantida tanto quanto possível independente do uso subsequente.

Destarte, os limites da planta de gaseificação foram configurados o mais próximo possível do tipo de gaseificador (incluindo os estágios de tratamento/limpeza do gás). Por conseguinte, não estão incluídos nos limites de ambos os sistemas os processos específicos para purificação e conversão do

\footnotetext{
${ }^{1}$ Estes dois tipos de CaC's são as que apresentam as melhores condições de integração com o sistema de gaseificação, nos quais, inclusive, é possível realizar a reforma do syngas internamente. Diferente das células de baixa temperatura de operação, onde a reforma deve ser externa, como por exemplo, a de Membrana Trocadora de Prótons (PEMFC) (Cf. capítulo 2).
} 
syngas em hidrogênio, bem como o armazenamento, distribuição e uso deste vetor energético. A figura 6.4 apresenta as atividades e processos inclusos nos limites dos sistemas de gaseificação estudados.

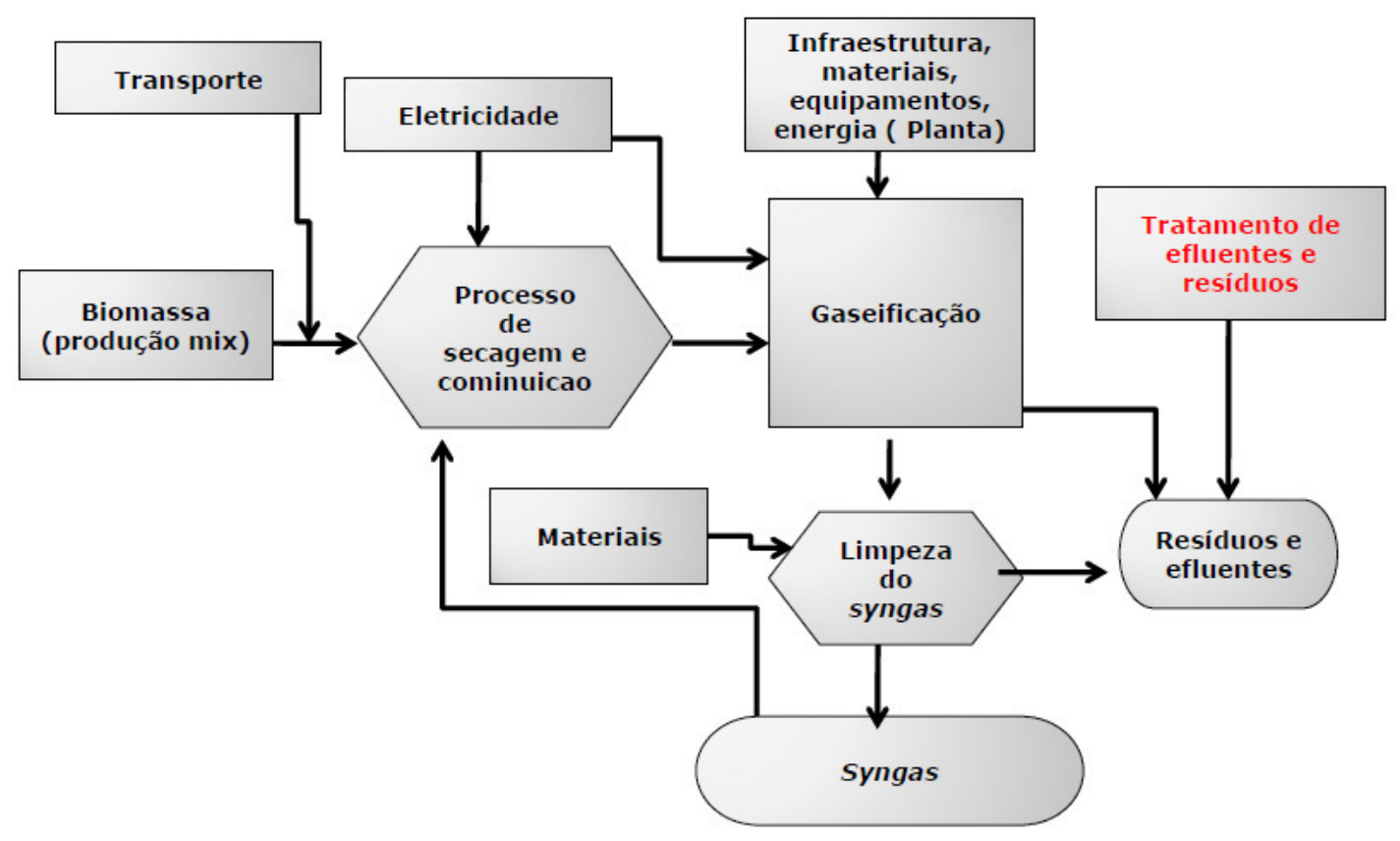

Figura 6.4 - Diagrama simplificado das atividades e processos incluídos nos limites dos sistemas de gaseificação estudados.

Devido à indisponibilidade de dados (relacionados a qualquer experiência comercial, estágio de demonstração e estudos específicos) sobre a construção de plantas de gaseificação, as plantas deste trabalho foram modeladas com base nos processos de fornos industriais de carvão de 1 a $10 \mathrm{MW}$. De acordo com Dauriat \& Gnansounou (2007), assume-se que tal tecnologia é relativamente similar, no mínimo, no que se refere ao tipo de reator. Considera-se que o tempo de vida útil da planta seja de 50 anos.

\subsubsection{Inventário}

\subsubsection{Características e composição da biomassa}

Para a produção de syngas foram utilizados três tipos de misturas de madeira de características (macia e dura) e de origens diferentes (florestal e industrial, incluindo os resíduos oriundos, por exemplo, da indústria da construção civil). Tal definição considerou as fontes de origem, características, além da participação no mercado, da madeira comumente utilizada nos processos de gaseificação. A composição típica e demais características são apresentadas na tabela 6.1. 
Tabela 6.1 - Composição típica da biomassa (lascas de madeira), percentual de umidade (u) e demais características utilizadas no estudo.

\begin{tabular}{|c|c|c|c|c|}
\hline \multicolumn{2}{|c|}{ Banco de dados (unidade básica) } & \multirow{2}{*}{$\begin{array}{l}\text { Lascas de madeira, } \\
\text { misturadas, } u=120 \% \text {, na } \\
\text { floresta }\left(\mathrm{m}^{3}\right)\end{array}$} & \multirow{2}{*}{$\begin{array}{c}\text { Lascas de } \\
\text { madeira, } \\
\text { misturadas, } \\
\text { origem industrial, } \\
\mathbf{u}=\mathbf{4 0 \%} \text {, na planta } \\
\text { ( } \mathbf{m}^{3} \text { ) } \\
72 \% \text { de lascas de } \\
\text { madeira macia, } 28 \% \\
\text { de lascas de } \\
\text { madeira dura }\end{array}$} & \multirow{2}{*}{$\begin{array}{c}\text { Lascas de madeira } \\
\text { descartadas, misturadas de } \\
\text { origem industrial, na planta } \\
\left(\mathrm{m}^{2}\right)\end{array}$} \\
\hline Tipos de madeiras inclusas & & & & \\
\hline Divisâo do mercado & $\%$ & $64 \%$ & $22 \%$ & $14 \%$ \\
\hline $\begin{array}{l}\text { Proporção de umidade na base } \\
\qquad \text { seca (u) }\end{array}$ & $\%$ wt. & $120 \%$ & $40 \%$ & $40 \%$ \\
\hline $\begin{array}{l}\text { Proporcão de umidade no total } \\
\text { da base }\end{array}$ & $\%$ wt. & $54.50 \%$ & $28.60 \%$ & $28.60 \%$ \\
\hline $\begin{array}{l}\text { Densidade da carga da base } \\
\text { seca }\end{array}$ & $\mathrm{kg} / \mathrm{m}^{3}$ seos & 188.6 & 188.6 & 188.6 \\
\hline Densidade aparente & $\mathrm{kg} / \mathrm{m}^{3}$ trencos & 414.9 & 264.0 & 264.0 \\
\hline $\begin{array}{l}\text { Poder Calorífico Inferior do } \\
\text { volume seco }\end{array}$ & $\mathrm{MJ} / \mathrm{m}^{3}$ soso & 3'294 & $3^{\prime} 465$ & $3^{\prime} 640$ \\
\hline $\begin{array}{c}\text { Poder Calorífico Inferior da } \\
\text { base seca }\end{array}$ & $\mathrm{MJ} / \mathrm{kg}$ seos & 18.9 & 18.9 & 19.8 \\
\hline $\begin{array}{l}\text { Tamanho padrão das lascas de } \\
\text { madeira }\end{array}$ & $\begin{array}{c}\mathrm{mm} \times \mathrm{mm} m \mathrm{~m} \\
\mathrm{~m}\end{array}$ & $70 \times 70 \times 70$ & $70 \times 70 \times 70$ & $70 \times 70 \times 70$ \\
\hline Oxigènio & $\mathrm{kg} / \mathrm{kg}$ & 0.494 & 0.494 & 0.438 \\
\hline Carbono, fóssil & $\mathrm{kg} / \mathrm{kg}$ & 0.000 & 0.000 & 0.000 \\
\hline Carbono, biogênico & $\mathrm{kg} / \mathrm{kg}$ & 0.441 & 0.441 & 0.443 \\
\hline Hidrogênio & $\mathrm{kg} / \mathrm{kg}$ & 0.061 & 0.061 & 0.057 \\
\hline Fonte & & Bauer (2003) & Bauer (2003) & Reichenbach de Sousa (2001) \\
\hline
\end{tabular}

As lascas de madeira descartadas são oriundas dos resíduos da construção e demolição (RCD). Esta madeira é coletada no local de demolição e transportada para as áreas de processamento de cominuição e, posteriormente, para a planta de gaseificação. A cadeia de suprimento de todos os tipos de madeiras, utilizadas no sistema, é ilustrada na figura 6.5 .

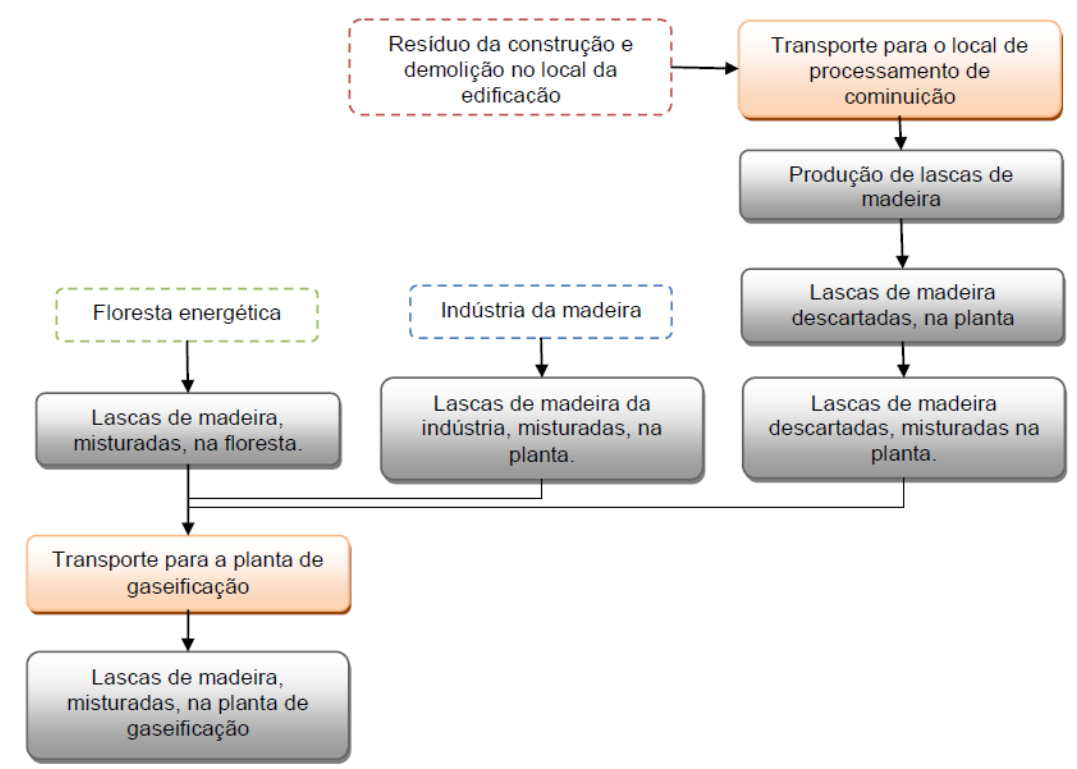

Figura 6.5 - Produção de lascas de madeira a partir dos resíduos da construção e demolição e suprimento de lascas de madeira para a planta de gaseificação (adaptado a partir de DAURIAT \& GNANSOUNOU, 2006). 
A madeira (na forma de lascas) pode ser utilizada em inúmeras aplicações e, para fins energéticos, o inventário da biomassa utilizada no estudo encontra-se disponíveis nos relatórios do banco de dados do Ecoinvent $n^{\circ} 06$ (BAUER et.al, 2003) e n 09 (WERNER et. al., 2003). Destaca-se que, no escopo do estudo, não estão inclusos os tratos culturais da madeira de origem florestal e tampouco da indústria de madeira.

Para o transporte utilizado no sistema de produção de lascas e suprimento de madeira para a planta de gaseificação, assume-se que o mesmo é executado por caminhões (carreta, 28 t) e a distância percorrida é, em média, de $50 \mathrm{~km}$ (tanto da floresta, quanto do local de cominuição para a planta). Esta hipótese está de acordo com outros processos relacionados a lascas de madeira do Ecoinvent. A tabela $\mathbf{6 . 2}$ apresenta os dados das unidades de processos considerados na produção da biomassa utilizada no estudo e a saída (output) do fluxo de referência $\left(\mathrm{m}^{3}\right.$ de madeira).

Tabela 6.2 - Dados das unidades do processo das diferentes misturas de lascas de madeira utilizadas no estudo e respectivas quantidades e valores

\begin{tabular}{|c|c|c|c|c|}
\hline \multicolumn{5}{|c|}{ Lascas de madeira, misturadas, $\mathrm{u}=120 \%$, na floresta } \\
\hline $\begin{array}{l}\text { Unidade básica } \\
\text { Lascas de madeira, macia, } u=140 \% \text {, na floresta } \\
\text { Lascas de madeira, dura, } u=80 \% \text {, na floresta } \\
\text { Volume final de lascas de madeira }\end{array}$ & $\begin{array}{c}\text { LFX } \\
\text { Quantidade } \\
21,125 \\
8,2152 \\
29,34\end{array}$ & $\begin{array}{c}\text { LFL } \\
\text { Quantidade } \\
19,701 \\
7,6614 \\
27,36\end{array}$ & $\begin{array}{l}\text { Unidade de medida } \\
\qquad \begin{array}{l}\mathrm{m}^{3} \\
\mathrm{~m}^{3} \\
\mathrm{~m}^{3}\end{array}\end{array}$ & $\begin{array}{c}\text { Fluxo } \\
\text { Input } \\
\text { Input } \\
\text { Output }\end{array}$ \\
\hline \multicolumn{5}{|c|}{ Lascas de madeira, misturadas, $\mathrm{u}=\mathbf{4 0} \%$, origem industrial, na planta } \\
\hline $\begin{array}{l}\text { Unidade básica } \\
\text { Lascas de madeira, macia, } u=40 \% \text {, origem industrial } \\
\text { Lascas de madeira, dura, } u=40 \% \text {, origem industrial } \\
\text { Volume final de lascas de madeira }\end{array}$ & $\begin{array}{c}\text { LFX } \\
\text { Quantidade } \\
7,2619 \\
2,8241 \\
10,086\end{array}$ & $\begin{array}{c}\text { LFL } \\
\text { Quantidade } \\
4,3094 \\
1,6759 \\
5,9853\end{array}$ & $\begin{array}{l}\text { Unidade de medida } \\
\qquad \begin{array}{l}\mathrm{m}^{3} \\
\mathrm{~m}^{3} \\
\mathrm{~m}^{3}\end{array}\end{array}$ & $\begin{array}{l}\text { Fluxo } \\
\text { Input } \\
\text { Input } \\
\text { Output }\end{array}$ \\
\hline \multicolumn{5}{|c|}{ Lascas de madeira, descartadas, misturadas, origem industrial, $u=40 \%$, na planta } \\
\hline Unidade básica & $\begin{array}{l}\text { LFX } \\
\text { Quantidade }\end{array}$ & $\begin{array}{c}\text { LFL } \\
\text { Quantidade }\end{array}$ & Unidade de medida & Fluxo \\
\hline $\begin{array}{l}\text { Disposição final, edificação de madeira, cromo } \\
\text { preservado, } u=20 \% \text {, para incineração municipal. }\end{array}$ & 1,8180 & 2,6641 & $\mathrm{~kg}$ & Input \\
\hline $\begin{array}{l}\text { Tratamento, produção de particulas, efluente para } \\
\text { tratamento na estação classe III }\end{array}$ & 0,0527 & 0,07726 & $\mathrm{~m}^{3}$ & Input \\
\hline $\begin{array}{l}\text { Residuos industriais de madeira, serralheria, serra } \\
\text { elétrica estacionária. }\end{array}$ & 1,2105 & 1773,9 & $\mathrm{~kg}$ & Input \\
\hline Serras & $5,006 \mathrm{E}-008$ & $7,3361 \mathrm{E}-008$ & pcs & Input \\
\hline Transporte, caminhão carreta, 28 t. & 84,733 & 124,17 & $\mathrm{tkm}$ & Input \\
\hline Agua $\quad$ Volume final de lascas de madeira & $\begin{array}{l}52,722 \\
6,4182\end{array}$ & $\begin{array}{l}77,26 \\
9,4054\end{array}$ & $\begin{array}{l}\mathrm{kg} \\
\mathrm{m}^{3}\end{array}$ & $\begin{array}{c}\text { Input } \\
\text { Output }\end{array}$ \\
\hline
\end{tabular}

Dada às respectivas densidades aparentes dos diferentes tipos das lascas de madeira, o peso efetivamente transportado de madeira é de $0,657 \mathrm{~kg} / \mathrm{Nm}^{3}$ para o leito fixo e de $0,645 \mathrm{~kg} / \mathrm{Nm}^{3}$ para o leito fluidizado. A medida $\mathrm{tkm}$ corresponde à massa $(\mathrm{t})$ de material transportado por kilômetro $(\mathrm{km})$ rodado. 


\subsubsection{Processo de gaseificação da biomassa}

Conforme apresentado no capítulo 3, a gaseificação consiste de uma série de distintos processos: aquecimento e secagem do combustível; pirólise do combustível sólido, condensação de vapores e materiais carbonáceos, reações sólido-gás, que consomem os materiais carbonáceos, e a fase de reações do gás que ajustam a composição química do syngas.

Os dois projetos de gaseificadores, leito fixo (LFX) e leito fluidizado (LFL) foram modelados com base nos dados do Ecoinvent. As características de ambos, utilizadas no presente estudo, são apresentadas na tabela 6.3.

\section{Tabela 6.3 - Características dos gaseificadores.}

\begin{tabular}{lcc}
\hline \multicolumn{1}{c}{ Processo } & Gaseificação LFX (1 MW) & Gaseificação LFL (1 MW) \\
Tecnologia & Leito fixo & Leito fluidizado \\
\hline Alimentação (base úmida) & $16,75 \mathrm{t}(\mathrm{dia})$ & $15,41 \mathrm{t}$ (dia) \\
Direto/Indireto & Indireto & Indireto \\
Atmosférico/Pressurizado & Atmosférico & Atmosférico \\
Air blow/Oxygen blow & Air blow & Air blow \\
Tratamento do gás & Limpeza do gás úmido a baixa & Limpeza do gás úmido a baixa \\
& temperatura & temperatura \\
Eficiência & $49,5 \%$ & $53,1 \%$ \\
\end{tabular}

O primeiro estágio do sistema de gaseificação consiste na redução do volume de água das lascas de madeira (utilizando o vapor ${ }^{2}$.) para um conteúdo de umidade na mistura de 10 a $15 \%$. A quantidade de calor requerida para os propósitos de secagem é de $0,890 \mathrm{MJ} / \mathrm{Nm}^{3}$.

No presente estudo, nos dois sistemas de gaseificação, considera-se que o calor necessário para a secagem é suprido pelo calor residual do próprio sistema de gaseificação e, portanto, o calor consumido para a secagem é 0 (zero). $O$ calor residual do processo é de 2,934 MJ por $\mathrm{Nm}^{3}$ de syngas líquido produzido.

Por outro lado, o processo de secagem também consome eletricidade de 0,025 kWh por kg de água evaporada (DAURIAT \& GNANSOUNOU, 2006), no qual cada sistema demanda diferentes quantidades de eletricidade, tal como no processo de cominuição. Destaca-se que, posterior à secagem da biomassa, torna-se

\footnotetext{
${ }^{2}$ A quantidade de vapor é calculada de acordo com a quantidade de água para evaporação e é dada por $2,8 \mathrm{MJ} / \mathrm{kg}$ de água evaporado (HAMMELINCK\& FAAIJ, 2001).
} 


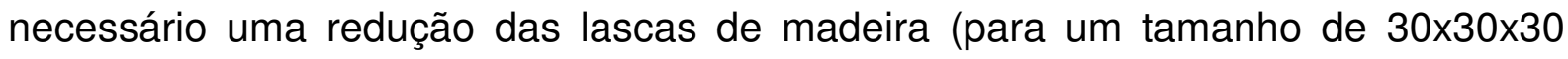
$\mathrm{mm}$ ) em ambos os sistemas.

Não obstante, a gaseificação requer uma quantidade de calor para direcionar a reação e, neste caso, o mesmo é fornecido pela combustão do syngas, após o processo de limpeza. No LFX, para cada $1,249 \mathrm{Nm}^{3}$ de syngas bruto produzido, $0,249 \mathrm{Nm}^{3}$ é utilizado para providenciar a energia térmica necessária para o processo, ou seja, cerca de $20 \%$ do total produzido.

No LFL, esta relação é de $0,232 \mathrm{Nm}^{3}$ para cada $1,232 \mathrm{Nm}^{3}$ de syngas bruto, isto é $18,8 \%$ do total de syngas produzido. Os requerimentos específicos de eletricidade e calor necessários para a operação dos dois sistemas são apresentados na tabela 6.4 .

Tabela 6.4 - Sumário da quantidade de calor e eletricidade requerida no sistema de gaseificação de leito fixo e leito fluidizado (adaptado a partir de DAURIAT \& GNANSOUNOU, 2006).

\begin{tabular}{|c|c|c|c|c|}
\hline \multirow{2}{*}{$\begin{array}{l}\text { Sistema } \\
\text { Processo }\end{array}$} & \multicolumn{2}{|c|}{ Planta de gaseificação leito fixo } & \multicolumn{2}{|c|}{ Planta de gasificação leito fluidizado } \\
\hline & $\begin{array}{c}\text { Consumo de calor } \\
\left(\mathrm{MJ} / \mathrm{Nm}^{3}\right)\end{array}$ & $\begin{array}{l}\text { Consumo de } \\
\text { eletricidade ( } \\
\mathrm{kWh} / \mathrm{Nm}^{3} \text { ) }\end{array}$ & $\begin{array}{c}\text { Consumo de calor } \\
\qquad\left(\mathrm{MJ} / \mathrm{Nm}^{3}\right)\end{array}$ & $\begin{array}{l}\text { Consumo de } \\
\text { eletricidade ( } \\
\mathrm{kWh} / \mathrm{Nm}^{3} \text { ) }\end{array}$ \\
\hline Secagem & 0 & 7,938 E-03 & 0 & 7,791 E-03 \\
\hline Cominuição & 0 & 3,450 E-03 & 0 & 3,387 E-03 \\
\hline Gaseificação & 9,328 E-01 & 0 & 9,156 E-01 & 0 \\
\hline Total ( liquido) & 9,328 E-01 & 2,201 E-02 & $9,156-01$ & 2,161E-02 \\
\hline
\end{tabular}

Referente às condições de operação e desempenho dos sistemas de gaseificação, consideradou-se a relação de equivalência - E/R (Cf. Cap. 3) e a razão de vapor / biomassa - steam to biomass ratio $(\mathrm{S} / \mathrm{B})^{3}$. Para o sistema LFX, assume-se que a razão típica de $E / R$ é 0,3 e, no $L F L$, de 0,276. Em relação a S/B, o valor considerado para ambos os sistemas de gaseificação é de 0,8691 (Cf. DAURIAT \& GNANSOUNOU, 2006).

\subsubsection{Limpeza do gás e composição do syngas produzido}

Conforme Lora e colaboradores (2008), a composição, o poder calorífico e a qualidade do gás, produzido por diferentes sistemas de gaseificação, indicam que as características do syngas são influenciadas pelo tipo de gaseificador. Ou seja, a escolha de uma dada tecnologia de conversão termoquímica da biomassa define, de

\footnotetext{
${ }^{3}$ Razão entre o fluxo de vapor entrando no sistema e a massa de fluxo de biomassa base seca. No sentido de mensurar o uso de vapor na gaseificação, o consumo é de fato indicado na forma de razão de vapor.
} 
certa forma, a composição do syngas e, portanto, também influencia a escolha de opções subsequentes para a síntese de hidrogênio.

De acordo com o NREL (2003), o gás produzido no processo de gaseificação requer condições adicionais para remover os materiais carbonáceos e impurezas inorgânicas. No LFX e no LFL, os processos de limpeza consistem basicamente na remoção de alcatrão, cinzas, álcalis, BTX (benzeno, tolueno e xileno) e halogêneos.

No presente estudo, os sistemas modelados apresentam o método de limpeza do gás úmido em baixa temperatura. Tal método demanda um requerimento de maior de energia e tratamento adicional de efluentes, porém é mais efetivo a curto e médio prazo do que limpeza do gás quente (DAURIAT \& GNANSOUNOU, 2004). A figura 6.4 apresenta o diagrama do processo de limpeza dos sistemas de gaseificação estudados.

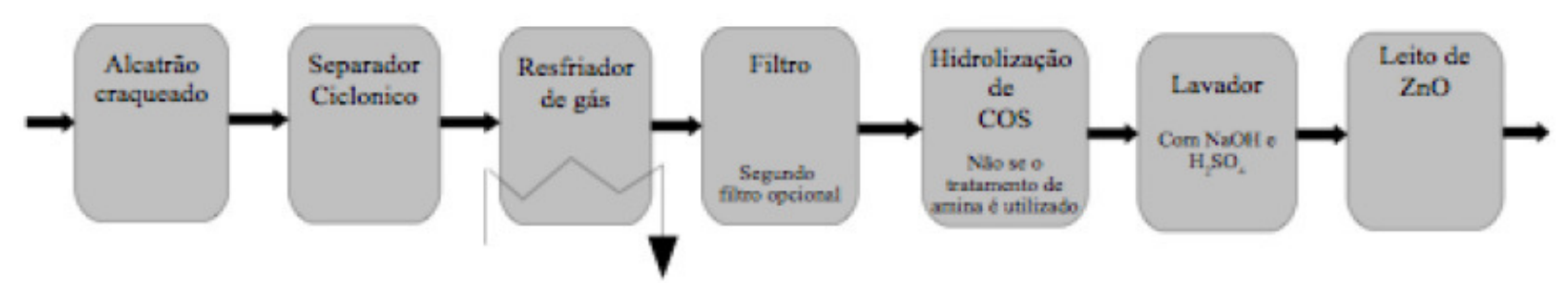

Figura 6.6 - Diagrama do processo de limpeza do gás úmido em baixa temperatura (DAURIAT \& GNANSOUNOU, 2006).

Para os gaseificadores atmosféricos, o processo de limpeza úmida a baixa temperatura inicia-se com craqueamento do alcatrão, cujo processo comumente utiliza dolomita. Sequencialmente, o syngas passa por um separador ciclônico, o qual remove a maior parte das impurezas sólidas, de tamanhos aproximados a $5 \mu \mathrm{m}$ (DAURIAT \& GNANSOUNOU, 2006).

Posteriormente, o gás é resfriado até acima do ponto de condensação da água, produzindo desta forma o vapor necessário ao processo. Na etapa de filtragem, partículas remanescentes e álcalis são removidas.

Em seguida, no estágio de purificação, o syngas é resfriado até $40^{\circ} \mathrm{C}$ abaixo do ponto de condensação. Partículas residuais, vapores químicos, gases halogênios e compostos de nitrogênio reduzidos são removidos em grandes quantidades pela água formada durante o segundo resfriamento. Usualmente, o purificador consiste em uma parte alcalina, onde a massa de H2S é removida com uma solução de $\mathrm{NaOH}$ e outra ácida para a remoção de amônia/ cianetos. Segundo Hamelinck 
(2001), não é necessário a remoção do enxofre para concentrações abaixo de 30 ppm de ácido sulfúrico presente no syngas bruto, uma vez que um leito de $\mathrm{ZnO} 4$ é o suficiente para reduzí-lo para menos de 0,1 ppm.

Destaca-se que a efetividade da limpeza úmida a baixa temperatura tem sido comprovada pelo ciclo combinado de gaseificação do carvão e aplicações na síntese de combustíveis por meio do processo Fischer-Tropsch. A composição típica do syngas, obtida a partir da gaseificação em LFX e LFL, é apresentada na tabela 6.5.

Tabela 6.5 - Composição típica do gás de síntese em leito fixo e leito fluidizado (DAURIAT \& GNANSOUNOU, 2006).

\begin{tabular}{|c|c|c|c|}
\hline \multicolumn{2}{|c|}{ Banco de dados (unidade básica) } & \multirow{2}{*}{$\begin{array}{l}\text { Gás de Síntese (Leito } \\
\text { Fixo) } \mathrm{Nm}^{3} \\
4.5\end{array}$} & \multirow{2}{*}{$\begin{array}{c}\text { Gás de Síntese (Leito } \\
\text { Fluidizado) } \mathrm{Nm}^{3} \\
4.7\end{array}$} \\
\hline Poder Calorífico Inferior & $\mathrm{MJ} / \mathrm{kg}$ & & \\
\hline Poder Calorífico Inferior & $\mathrm{MJ} / \mathrm{Nm}^{3}$ & 5.2 & 5.4 \\
\hline Densidade $20^{\circ} \mathrm{C}$ & $\mathrm{kg} / \mathrm{m}^{3}$ & 1.15 & 1.15 \\
\hline Oxigênio & kg/kg & 0.305 & 0.314 \\
\hline Carbono, fóssil & $\mathrm{kg} / \mathrm{kg}$ & 0.000 & 0.000 \\
\hline Carbono, biogênico & $\mathrm{kg} / \mathrm{kg}$ & 0.135 & 0.140 \\
\hline Hidrogênio & $\mathrm{kg} / \mathrm{kg}$ & 0.026 & 0.021 \\
\hline Nitrogênio & $\mathrm{kg} / \mathrm{kg}$ & 0.533 & 0.525 \\
\hline
\end{tabular}

Particularmente no que se refere à composição do syngas, observa-se que, dada à natureza de operação ${ }^{5}$ do LFX, este apresenta cerca de $20 \%$ a mais de hidrogênio do que o LFL.

Conforme pode ser observado nas tabelas 6.6 e 6.7 , embora existam algumas similaridades entre o FLX e o LFL, cada sistema de gaseificação demanda diferentes quantidades de biomassa e materiais no processo de produção do syngas (como por exemplo, a areia no LFL), entre outros, dada as especificidades de operação (Cf. Cap. 3).

\footnotetext{
${ }^{4} \mathrm{O} \mathrm{ZnO}$ é funcional por um ano e não se regenera.

${ }^{5}$ De acordo com Quaak et. al (1998), os principais componentes do gás produzido pelo gaseificador de leito fixo são monóxido de carbono e hidrogênio, formados na zona de redução, no qual ,além de outras várias reações, o carbono é convertido.
} 
Tabela 6.6 - Dados das unidades de processo da planta de gaseificador de leito fixo (1MW) utilizadas no estudo e respectivas quantidades e tipo de fluxo.

\begin{tabular}{|c|c|c|c|}
\hline \multicolumn{4}{|c|}{ Planta Gaseificador Leito Fixo (1 MW) } \\
\hline Unidade básica & Quantidade & $\begin{array}{l}\text { Unidade de } \\
\text { medida }\end{array}$ & Fluxo \\
\hline Lascas de madeira, misturadas, $\mathrm{u}=120 \%$, na planta & 29,34 & $\mathrm{~m}^{3}$ & Input \\
\hline Lascas de madeira, misturadas, $\mathrm{u}=40 \%$, origem industrial, na planta & 6,4182 & $\mathrm{~m}^{3}$ & Input \\
\hline Lascas de madeira, descartadas, misturadas, origem industrial, $\mathrm{u}=40 \%$, na planta & 10,086 & $\mathrm{~m}^{3}$ & Input \\
\hline $\mathrm{NaOH}, 50 \%$ em água, produção mix, na planta & 13,944 & $\mathrm{~kg}$ & Input \\
\hline $\mathrm{H}_{2} \mathrm{SO}_{4}$ liquido, na planta. & 55,404 & $\mathrm{~kg}$ & Input \\
\hline Água, no local do usuário. & 2458 & $\mathrm{~kg}$ & Input \\
\hline Eletricidade, média voltagem, na rede de distribuição. & 1644,4 & MJ & Input \\
\hline Planta de gás sintético & 1,5152 E-005 & pcs & Input \\
\hline Transporte de bens, trem & 61,243 & $\mathrm{tkm}$ & Input \\
\hline Transporte, carreta, $28 \mathrm{t}$ & 691,61 & tkm & Input \\
\hline Tratamento, esgoto, do local para a estação de tratamento, classe 2 & 1,6859 & $\mathrm{~m}^{3}$ & Input \\
\hline Forno industrial, gás natural & 3,1467 E-005 & pcs & Input \\
\hline Destinação final, mistura de cinzas, puro, $0 \%$ de $\mathrm{H}_{2} \mathrm{O}$, para incineração municipal & 38,397 & $\mathrm{~kg}$ & Input \\
\hline Destinação final, mistura de cinzas, puro, $0 \%$ de $\mathrm{H}_{2} \mathrm{O}$, para aterro sanitário & 29,005 & $\mathrm{~kg}$ & Input \\
\hline Emissões de $\mathrm{CO}_{2}$ & 0,347 & $\mathrm{~kg} / \mathrm{Nm}^{3}$ & Output \\
\hline Volume final liquido de syngas & 16615 & $\mathrm{Nm}^{3}$ & Output \\
\hline
\end{tabular}

Nota: a unidade básica pode ser dividida em recursos (água), materiais (NaOH), infraestrutura (plantas, sistemas de tratamento), energia (eletricidade, térmica), transporte e emissões. 
Tabela 6.7 - Dados das unidades de processo da planta de gaseificador de leito fluidizado (1MW) utilizadas no estudo e respectivas quantidades e tipo de fluxo.

\section{Planta Gaseificador Leito Fluidizado (1 MW)}

\section{Unidade básica}

Lascas de madeira, misturadas, $\mathrm{u}=120 \%$, na planta

Lascas de madeira, misturadas, $\mathrm{u}=40 \%$, origem industrial, na planta

Lascas de madeira, descartadas, misturadas, origem industrial, $u=40 \%$, na planta

$\mathrm{NaOH}, 50 \%$ em água, produção mix , na planta

Areia, sílica, na planta

Dolomita, na planta

Zeólita, na planta

$\mathrm{H}_{2} \mathrm{SO}_{4}$ liquido, na planta

Água, no local do usuário.

Eletricidade, média voltagem, na rede de distribuição

Planta de gás sintético

Transporte de bens, trem

Transporte, carreta, $28 \mathrm{t}$

Tratamento, esgoto, do local para a estação de tratamento, classe 2

Forno industrial, gás natural

Destinação final, mistura de cinzas, puro, $0 \%$ de $\mathrm{H}_{2} \mathrm{O}$, para incineração

municipal

Destinação final, material inerte, $5 \%$ de $\mathrm{H}_{2} \mathrm{O}$, para aterro de materiais inertes

Destinação final, zeolita, $5 \%$ de $\mathrm{H}_{2} \mathrm{O}$, para aterro de material inertes

\section{Quantidade}

27,362

9,4054

5,9853

13,248

201,57

162,51

33,285

52,637

2292,2

1533,5

4935 E-005

56,374

660,9

0,97512

3,0302 E-005

35,608

364,08

33,285

27,048

0,322

16000

Unidade de
medida
$\mathrm{m}^{3}$
$\mathrm{~m}^{3}$
$\mathrm{~m}^{3}$
$\mathrm{~kg}$
$\mathrm{~kg}$
$\mathrm{~kg}$
$\mathrm{~kg}$
$\mathrm{~kg}$
$\mathrm{~kg}$
$\mathrm{MJ}$
$\mathrm{pcs}$
$\mathrm{tkm}$
$\mathrm{tkm}$
$\mathrm{m}^{3}$
$\mathrm{pcs}$
$\mathrm{kg}$
$\mathrm{kg}$
$\mathrm{kg}$
$\mathrm{kg}$
$\mathrm{kg} / \mathrm{Nm}{ }^{3}$
$\mathrm{Nm}$

Fluxo

Input

Input

Input

Input

Input

Input

Input

Input

Input

Input

Input

Input

Input

Input

Input

Input

Input

Input

Input

Output

Output 
Segundo Lora e colaboradores (2008), os gaseificadores de leito fixo contracorrente apresentam um gás com alto teor de alcatrão ${ }^{6}$, em torno de 20 a 100 $\mathrm{g} / \mathrm{Nm}^{3}$. Isto, por sua vez, demanda um extensivo processo de limpeza do gás (QUAAK et. al, 1998). De fato, é possível observar que o LFX consome uma maior quantidade de água ( $2458 \mathrm{~kg}$ ) e, consequentemente, produz mais efluentes do que o LFL, cerca de $1,70 \mathrm{~m}^{3}$ (notadamente em função do processo de limpeza do gás adotado). Em contraposição, o LFL produz uma carga maior de resíduos do que LFX, resultante em grande parte do material utilizado (areia) no leito $(365 \mathrm{~kg})$, o qual é regularmente e parcialmente renovado.

Especificamente em relação às emissões para os diferentes compartimentos ambientais (ar, água e solo), mais de $90 \%$ das emissões resultantes do processo produtivo, tanto do sistema LFX, quanto do LFL, são emissões atmosféricas. Tal como observado por Mann \& Spath (1997), de todas as emissões atmosféricas, o $\mathrm{CO}_{2}$ é produzido em grande quantidade. A tabela 6.8 apresenta as principais contribuições em relação às emissões para 0 ar (orgânicas e inorgânicas) dos sistemas estudados em $\mathrm{kg}$ de $\mathrm{CO}_{2}$ equivalente.

Tabela 6.8 - Síntese das principais emissões atmosféricas (orgânicas e inorgânicas) dos sistemas de gaseificação estudados.

\begin{tabular}{|c|c|c|}
\hline Emissöes atmosféricas & Planta Gaseificador Leito Fixo & Planta Gaseificador Leito Fluidizado \\
\hline Emissões inorgânicas & $\mathrm{Kg} \mathrm{CO}_{2}$ Equlvalente & $\mathrm{Kg} \mathrm{CO}_{2}$ Equlvalente \\
\hline " & $5,4 \mathrm{E} 002$ & $4,2 \mathrm{EOO} 2$ \\
\hline $\mathrm{CO}_{2}$ (biótico) & $5,2 \mathrm{E} 003$ & $6,2 \mathrm{E} 003$ \\
\hline $\mathrm{CO}_{2}$ (transformação do solo) & 0,015 & 0,011 \\
\hline $\mathrm{NO}_{\mathrm{x}}$ & 5,4 & 4,8 \\
\hline Hexafluoreto de enxofre & 0,86 & 0,71 \\
\hline Total & $5,7 \mathrm{E} 003$ & $6,7 \mathrm{E} 003$ \\
\hline Emissões orgânicas & $\mathrm{Kg} \mathrm{CO}_{2}$ Equivalente & $\mathrm{Kg} \mathrm{CO} 2$ Equilvalente \\
\hline NMVOC & 3,1 & 3 \\
\hline $\mathrm{CH}_{4}$ & 19 & 14 \\
\hline $\mathrm{CH}_{4}$ (biótico) & 0,62 & 0,59 \\
\hline Total & 23 & 18 \\
\hline
\end{tabular}

Ressalta-se que, o carbono presente nos efluentes e resíduos, foi considerado convertido em $\mathrm{CO}_{2}$, de uma maneira ou outra, no final do processo de gaseificação (por exemplo, no tratamento de esgoto ou na planta de incineração), resultando, portanto, em emissões de dióxido de carbono para a atmosfera. Desta forma, as emissões globais de $\mathrm{CO}_{2}$ foram mensuradas de forma a fechar o balanço de carbono.

\footnotetext{
${ }^{6}$ Embora os gaseificadores de LFL também apresentem uma grande quantidade de alcatrão no gás produzido, os valores médios registrados (na faixa de $15 \mathrm{~g} / \mathrm{Nm}^{3}$ ) ainda são menores do os encontrados no LFX .
} 


\section{RESULTADOS E DISCUSSÕES}

\section{1.3 Análise do Balanço Energético}

\subsubsection{Demanda Acumulada de Energia e Tempo de Retorno em Investimento de Energia}

Conforme apresentado na metodologia, a demanda acumulada de energia primária (CED) para os dois sistemas foi calculada considerando o escopo do estudo e os dados do inventário. Os resultados obtidos do CED de ambos os sistemas, relativos às variáveis independentes do tempo $\left(E_{o}\right)$ são apresentados na figura 6.7.

No sistema de gaseificação em leito fluidizado, a CED equivalente em $E_{0}$ foi de 13.336 MJ. Deste montante, 12.495 MJ correspondem aos recursos não renováveis de energia (REN), $840 \mathrm{MJ}$ aos recursos renováveis (RER) e 0,026 MJ aos recursos de energia contida em materiais (M). No gaseificador em LFX, a CED total foi $11.150 \mathrm{MJ}$, na qual a distribuição da demanda entre ENR, RN e $M$ é de $10.325 \mathrm{MJ} ; 802 \mathrm{MJ}$ e 0,025 MJ, respectivamente.

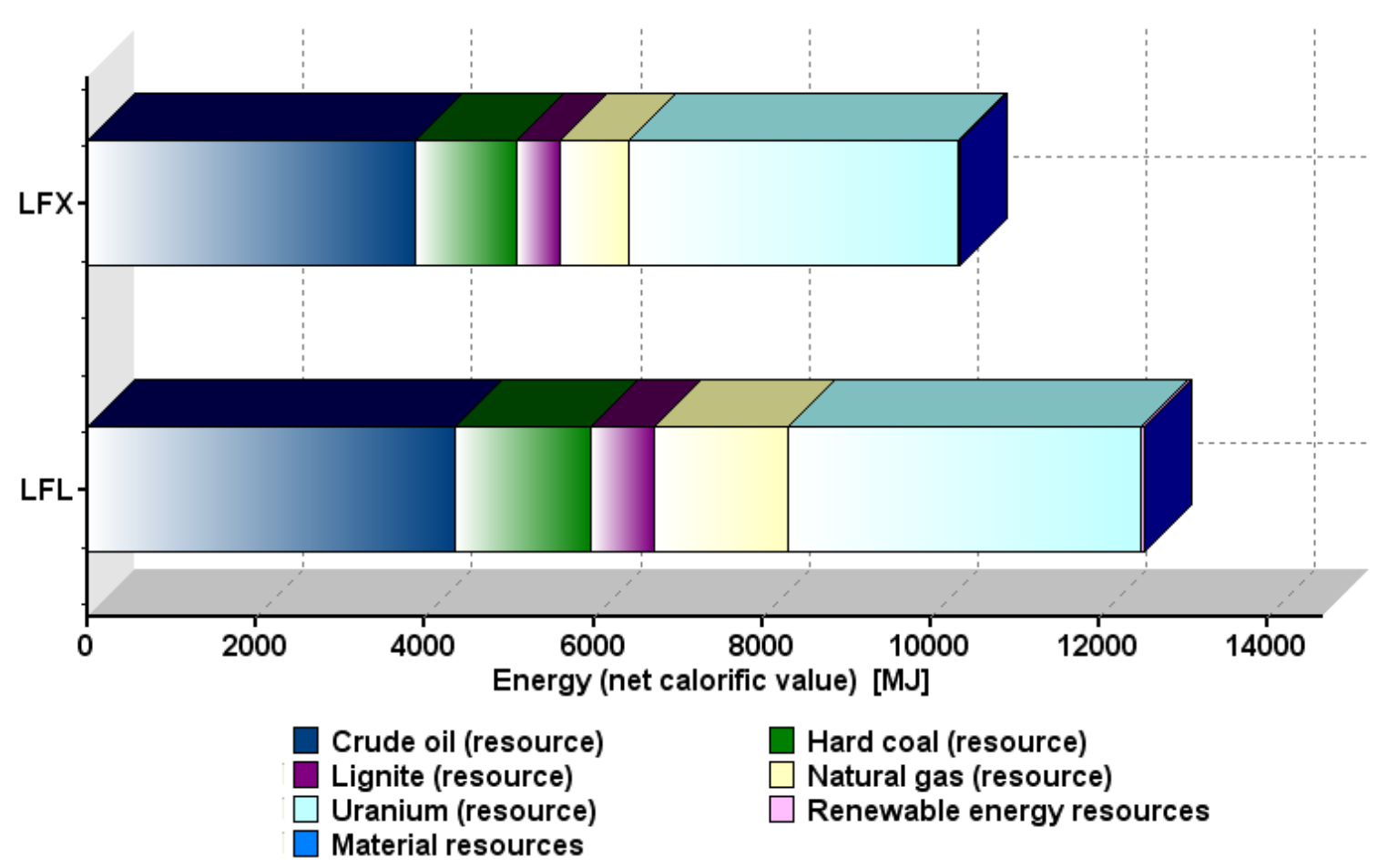

Figura 6.7 - Demanda Acumulada de Energia (CED, $E_{0}$ ) dos sistemas de gaseificação estudados (valor líquido calorífico em MJ).

$\mathrm{Na}$ contribuição relativa de CED de recursos não renováveis destaca-se a participação do óleo cru (combustível) e do urânio (eletricidade) em ambos os sistemas. Cabe ressaltar que a participação de recursos não renováveis, como por exemplo, urânio e carvão, são resultantes da fonte de suprimento de eletricidade, 
inventariados no banco de dados (Ecoinvent) e utilizada para modelar os sistemas. Neste caso, da matriz energética européia.

No LFL, os respectivos valores encontrados foram de $33 \%$ e $31 \%$, enquanto no LFX, o percentual é de $35 \%$ para os dois recursos. Estes valores correspondem ao consumo de energia durante a fase de manufatura (requerimentos de materiais), instalação e descomissionamento da planta (transporte de materiais, operação de máquinas e equipamentos). A tabela 6.9 apresenta o percentual de contribuição relativa na demanda e os valores obtidos (valor calorífico líquido em MJ) em cada um destes três parâmetros.

Tabela 6.9 -CED das variáveis independentes do tempo (CED, $E_{\circ}$ ).

\begin{tabular}{|c|c|c|c|c|}
\hline & \multicolumn{2}{|c|}{ Leito fluidizado } & \multicolumn{2}{|c|}{ Leito fixo } \\
\hline & $\begin{array}{c}\text { Contribuiçäo relativa } \\
\text { (\%) }\end{array}$ & $\begin{array}{c}\text { Valores absolutos } \\
\text { (MJ) }\end{array}$ & $\begin{array}{c}\text { Contribuição relativa } \\
(\%)\end{array}$ & $\begin{array}{c}\text { Valores absolutos } \\
\text { (MJ) }\end{array}$ \\
\hline $\begin{array}{l}\text { Recursos de energia nảo } \\
\text { renovável (total) }\end{array}$ & 94 & 12495 & 93 & 10325 \\
\hline Oleo Cru & 33 & 4354 & 35 & 3878 \\
\hline Carvảo mineral & 12 & 1608 & 11 & 1213 \\
\hline Lignina & 6 & 762 & 5 & 515 \\
\hline Gás natural & 12 & 1571 & 7 & 802 \\
\hline Urânio & 31 & 4200 & 35 & 3917 \\
\hline Recursos de energia renovável & 6 & 840 & 7 & 825 \\
\hline $\begin{array}{l}\text { Recursos de energia em } \\
\text { materiais }\end{array}$ & 0 & 0 & 0 & 0 \\
\hline Total de recursos de energia & 100 & 13336 & 100 & 11150 \\
\hline
\end{tabular}

Quanto à CED das variáveis dependentes do tempo $\left(E_{u}\right)$, a demanda de energia auxiliar $\left(E_{A}\right)$ corresponde ao consumo de eletricidade durante o processo de operação do sistema, enquanto a energia de combustíveis refere-se ao diesel (contabilizado como óleo cru) utilizado no transporte da biomassa para planta de gaseificação.

Tal como mencionado anteriormente, nos dois sistemas de gaseificação, o transporte da biomassa é executado por caminhões com capacidade de carga de $28 \mathrm{t}$ e a distância percorrida por dia é de $50 \mathrm{~km}$. No LFX, a massa transportada por km rodado (tkm) é de 692 tkm, enquanto no LFX é de 661 tkm (Cf. tabela 10.6 e 10.7).

O consumo diário de diesel tanto no LFX e LFL é de 0,058 $\mathrm{kg} / \mathrm{dia}$, o que corresponde a 2,5 MJ/dia ( $\mathrm{PCl} 43 \mathrm{MJ}$ ). $\mathrm{O}$ transporte de biomassa contabilizado 


\section{RESULTADOS E DISCUSSÕES}

durante o tempo de vida útil da planta (50 anos) para o leito fixo foi 11,4 E006 tkm e do LFL de 10,9 E006 tkm.

Neste sentido, a demanda acumulada de energia relativa ao transporte do sistema do LFX é de 28,5 TJ e do LFL de 27 TJ. Embora o tipo de veículo, a distância percorrida e o consumo diário de diesel sejam iguais nos dois sistemas, 0 LFX apresenta maior CED do que LFL, principalmente por requerer maior quantidade de biomassa para produzir a mesma quantidade de energia.

Similarmente, o consumo de eletricidade no LFX é maior (21,5 TJ) do que no LFL (19,8 TJ) e, neste caso, as diferenças entre a composição da biomassa (tipos e percentual de umidade) influenciam a demanda deste tipo de energia durante a operação da planta (Figura 6.8).

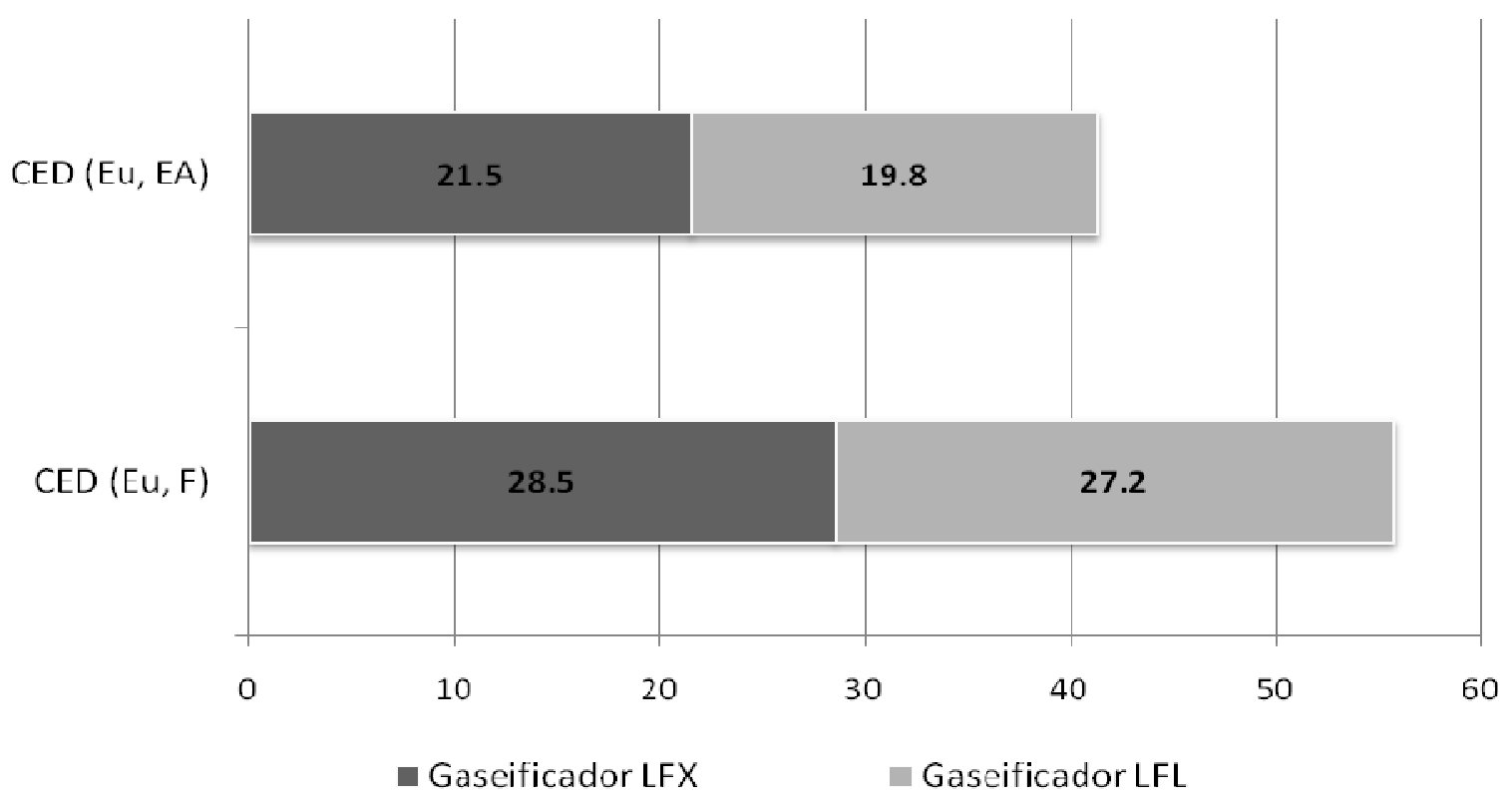

Figura 6.8 -CED das variáveis dependentes do tempo - Energia auxiliar $\left(E_{U}, E_{A}\right)$ e Transporte $\left(E_{U}, F\right)$.

A somatória da CED das variáveis dependentes $\left(E_{u}\right)$ e independentes do tempo $\left(E_{o}\right)$ corresponde a 50,01 TJ no LFX e 47,01 TJ MJ no LFL. Em ambos os sistemas observa-se que a CED de recursos não renováveis, em grande parte, deve-se ao uso de combustíveis fósseis utilizados no transporte da madeira para a planta de gaseificação, cujo fator é influenciado fortemente pelo montante transportado e as distâncias percorridas.

De fato, conforme o estudo sobre a CED de plantas de combustão da biomassa, realizado por Nussbaumer \& Oser (2004), o combustível utilizado no 
transporte da biomassa está entre os mais relevantes parâmetros que influenciam o valor final da CED e, consequentemente, o EPBT. Em menor percentual, porém não menos relevante, encontra-se a demanda de energia auxiliar necessária para os processos de redução do tamanho (cominuição) e a secagem da madeira, bem como nos processos de limpeza do syngas.

Neste sentido, observa-se que, para a mesma capacidade de produzir energia (1MW), o processo de gaseificação em leito fixo apresenta uma maior CED no seu ciclo de vida, quando comparado ao leito fluidizado. No que se refere à produção de energia anual líquida do LFX, esta é de 28,31 TJ e a do LFL é de 28,51 TJ. O EPBT encontrado para o sistema LFX é de 1,77 anos e a do LFL é de 1,65 anos.

A tabela 6.10 apresenta a demanda de energia das variáveis dependentes e independentes do tempo, a CED integrada (total), bem como as produções anuais de energia líquida e EPBT dos sistemas estudados.

Tabela 6.10-CED das variáveis independentes $\left(E_{0}\right)$ e independentes $\left(E_{U} / E_{A}, E_{F}\right)$ do tempo, CED integrada $\left(E_{o}, E_{U}\right)$, Produção Anual Líquida (PAE) e Tempo de Retorno de Investimento em Energia (EPBT) dos sistemas de gaseificação LFX e LFL.

\begin{tabular}{ccccccc}
\hline Sistema & $\begin{array}{c}{\left[E_{0}\right]} \\
(\mathrm{TJ})\end{array}$ & $\begin{array}{c}{\left[\mathrm{E}_{\mathrm{u}}, \mathrm{E}_{\mathrm{A}}\right]} \\
(\mathrm{TJ})\end{array}$ & $\begin{array}{c}{\left[\mathrm{E}_{\mathrm{u}, \mathrm{F}}\right]} \\
(\mathrm{T} \mathrm{J})\end{array}$ & $\begin{array}{c}{\left[\mathrm{E}_{\mathrm{O}} \mathrm{E}_{\mathrm{v}}\right]} \\
(\mathrm{TJ})\end{array}$ & $\begin{array}{c}\text { PAE } \\
(\mathrm{TJ})\end{array}$ & $\begin{array}{c}\text { EPBT } \\
\text { (anos) }\end{array}$ \\
Gaseificador LFX & 0,0115 & 21,5 & 28,5 & 50,01 & 28,31 & 1,77 \\
Gaseificador LFL & 0,0133 & 19,8 & 27,3 & 47,11 & 28,51 & 1,65 \\
\hline
\end{tabular}

Por fim, é possível constatar que, apesar das diferenças entre os dois sistemas de gaseificação (pertinentes ao consumo e produção de energia), estas não são tão significativas quando comparadas em termos de EPBT. O tempo de retorno de investimento em energia do LFX é praticamente o mesmo que o LFL, com uma diferença de apenas 43,5 dias a mais do LFX para o LFL.

Ao consideramos o tempo de vida útil das plantas (50 anos), o fator do balanço energético líquido ${ }^{7}$ é 28 para ambos os sistemas. Isto significa que os dois

\footnotetext{
${ }^{7}$ Também nomeado como Energy Yield Factor ou Energy Return Factor ( Alsema, 1998) e Net Energy Ratio (Pacca et. al, 2007). É dado por: PAE.Tempo de Vida Útil (tw )/ CED.
} 


\section{RESULTADOS E DISCUSSÕES}

sistemas produzem 28 vezes mais energia do que consomem no seu inteiro ciclo de vida (CED).

\subsubsection{Avaliação de Impacto Ambiental}

Conforme apresentado no capítulo 5, os dois sistemas de gaseificação foram avaliados segundo a metodologia do Eco-indicador 99. Os resultados obtidos (normalizados e ponderados) de todos os parâmetros avaliados em cada categoria de dano, qualidade do ecossistema (QE), saúde humana $(\mathrm{SH})$ e, recursos minerais e combustíveis fósseis (RMCF) são apresentados na Figura 6.9.

Dentre os diversos parâmetros avaliados, as duas contribuições mais significativas, em ambos os sistemas, estão relacionadas aos danos à saúde humana, isto é: Mudanças Climáticas e Efeitos Respiratórios (causados por substâncias inorgânicas). No parâmetro Mudanças Climáticas, o LFX apresenta uma contribuição de $64,69 \%$, enquanto o LFL é $55,68 \%$. Por outro lado, em relação aos efeitos respiratórios, o LFL contribui cerca de $5 \%$ a mais do que o LFX.

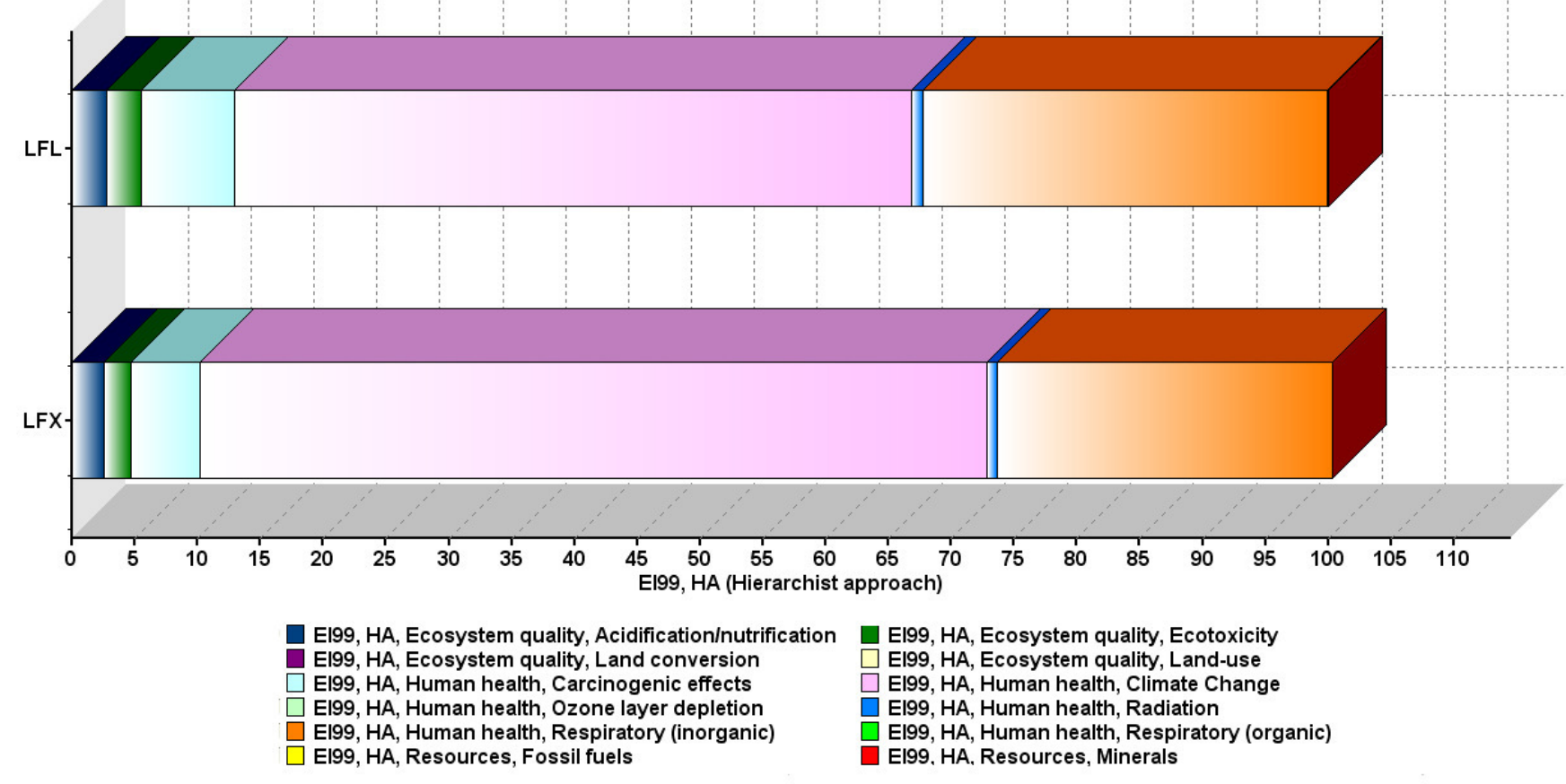

Figura 6.9 - Contribuição relativa dos danos a SH, QE e RMCF dos sistemas LFL e LFX (\%).

De fato, o LFX apresenta uma maior quantidade de emissões (NMVOC, $\mathrm{CH}_{4}$ e $\mathrm{CH}_{4}$ biótico), que colaboram para os danos às Mudanças Climáticas, modelados no El 99 e, menor no que se refere às emissões inorgânicas do que LFL (Cf. tabela 
6.8). Contudo, em termos de valor agregado, a contribuição dos danos à SH no LFX é maior do que LFL (Figura 6.10).

Figura 6.10 - Contribuição relativa (mudanças climáticas e efeitos respiratórios inorgânicos) dos sistemas de LFL e LFX na categoria de danos a saúde humana (\%).

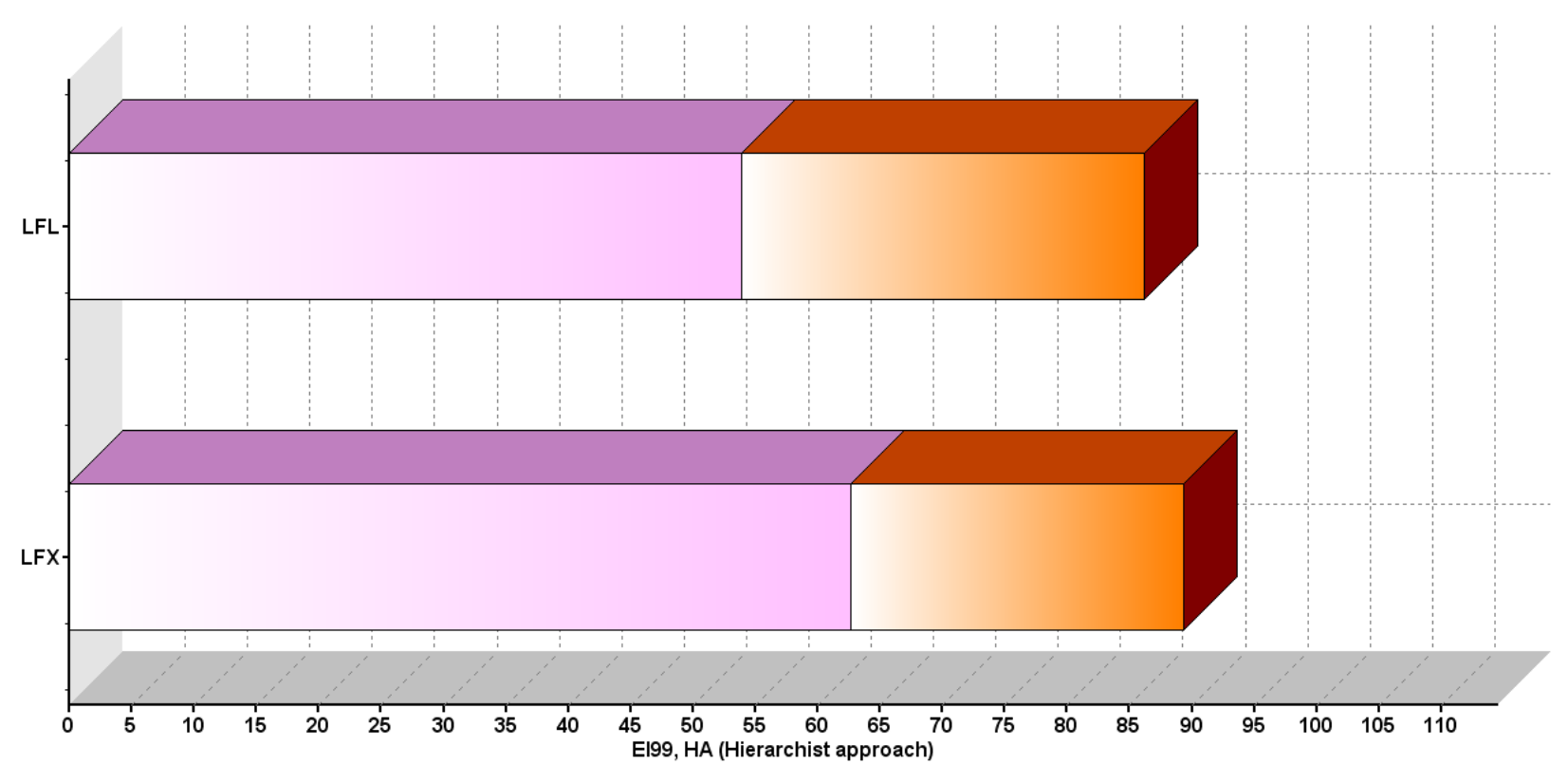

$\square$ El99, HA, Human health, Climate Change

$\square$ El99, HA, Human health, Respiratory (inorganic)

Referente à qualidade do ecossistema, somente os parâmetros acidificação e eutrofização, bem como ecotoxicidade apresentaram contribuições (apesar de relativamente menores), tanto no LFX, quanto no LFL (Figura 6.11). Nesta categoria de dano, o leito fixo tem uma menor carga ambiental $(4,82 \%)$ do que o sistema LFL $(5,72 \%)$, justificada pela menor quantidade de emissões de $\mathrm{CO}_{2}$ equivalente (Cf. tabela 6.8).

Em relação aos parâmetros dos recursos minerais e de combustíveis fósseis, não houve nenhuma contribuição oriunda dos sistemas de gaseificação; similar ao ocorrido nos demais parâmetros das categorias saúde humana e qualidade do ecossistema, em que as contribuições foram nulas ou menores do $0 \%$.

Tal ocorrência pode ser atribuída ao fato de uma dada substância (presente nas emissões inventariadas dos sistemas) contribuir para mais de um efeito ambiental, no qual, dependendo dos valores de normalização e ponderação adotadas no Eco-indicador 99 (Cf. capitulo 5), apresenta um peso maior em uma dada categoria do que em outra. 


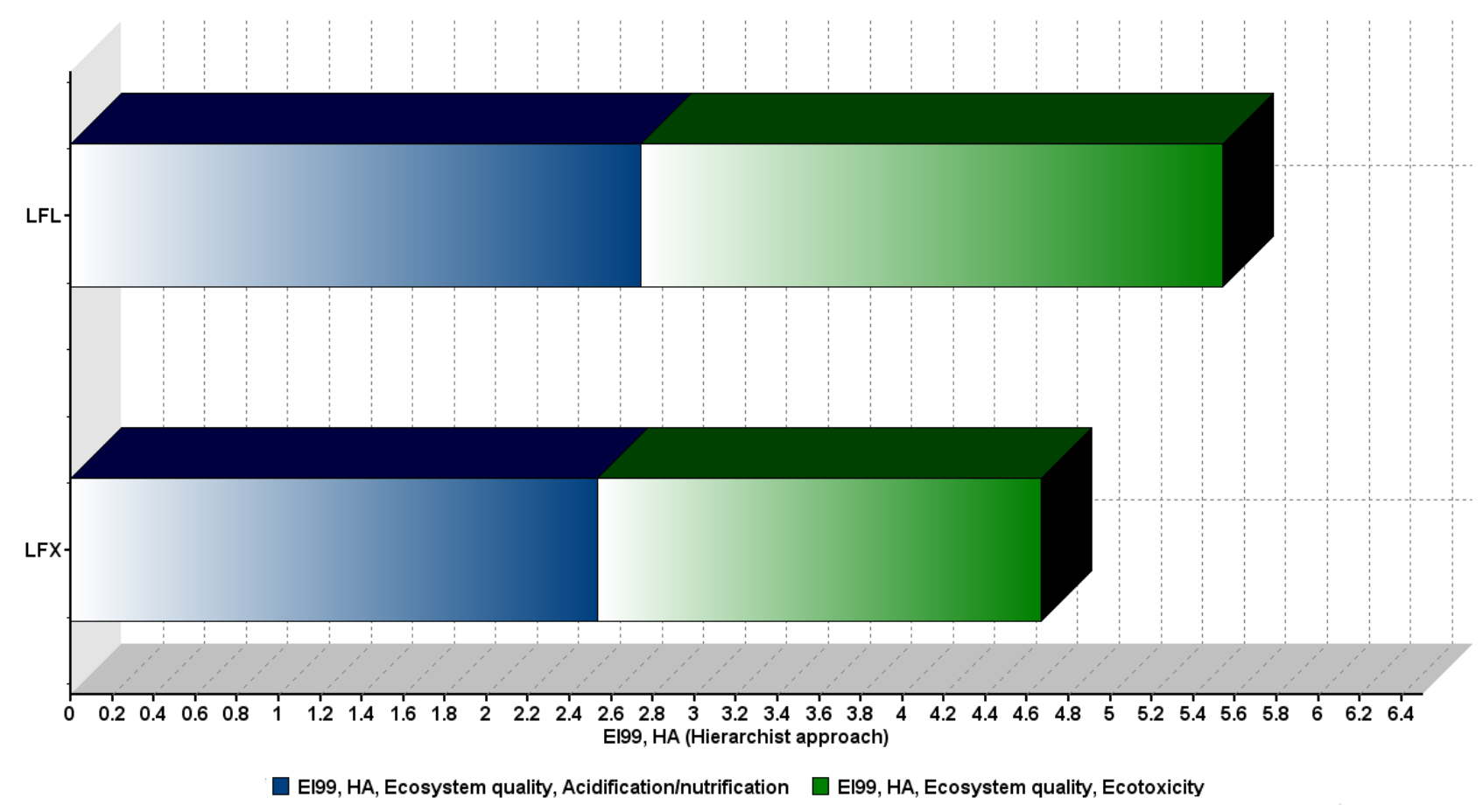

Figura 6.11 - Contribuição relativa (acidificação/eutrofização e ecotoxicidade) dos sistemas de LFL e LFX na categoria de danos a qualidade do ecossistema (\%).

Não obstante, conforme apresentado na metodologia, determinados efeitos no meio ambiente, decorrentes do uso de recursos, não foram considerados. Por exemplo, na modelagem dos danos dos recursos minerais e combustíveis fósseis, o uso do solo não é contabilizado por encontraram-se cobertos na modelagem da qualidade do ecossistema. A tabela 6.11 apresenta as contribuições relativas dos diferentes parâmetros utilizados na avaliação de impacto e o valor agregado por categoria (QE, SH, RMCF).

Tabela 6.11 - Contribuição relativa dos diferentes parâmetros utilizados na avaliação de impacto e valor agregado por categoria de dano (\%) dos sistemas LFL e LFX.

\begin{tabular}{|c|c|c|c|c|}
\hline Eco-indicador 99 & Leito fluidizado & Valor agregado & Leito fixo & Valor Agregado \\
\hline QE - Acidificaçăo/Nitrificação & 2,83 & & 2.61 & \\
\hline QE - Ecotoxicidade & 2,89 & & 2.21 & \\
\hline QE - Uso do Solo & 0,00 & & 0.00 & \\
\hline SH - Efeitos carcinogênicoe & 7,60 & & 5.71 & \\
\hline SH - Mudanças climáticas & 55,68 & & 64.69 & \\
\hline SH - Efeitos respiratórios (inorgânicos) & 30,01 & & 25.15 & \\
\hline SH- Efeitos respiratórios (orgânicos) & 0,05 & & 0.05 & \\
\hline RMCF - Combustiveis fósseis & 0,00 & & 0.00 & \\
\hline RMCF - Recursos minerais & 0,00 & 0.00 & 0.00 & 0.00 \\
\hline Total & 100 & 100 & 100 & 100 \\
\hline
\end{tabular}

A comparação do desempenho ambiental dos dois sistemas de gaseificação estudados é ilustrada na figura 6.12. 


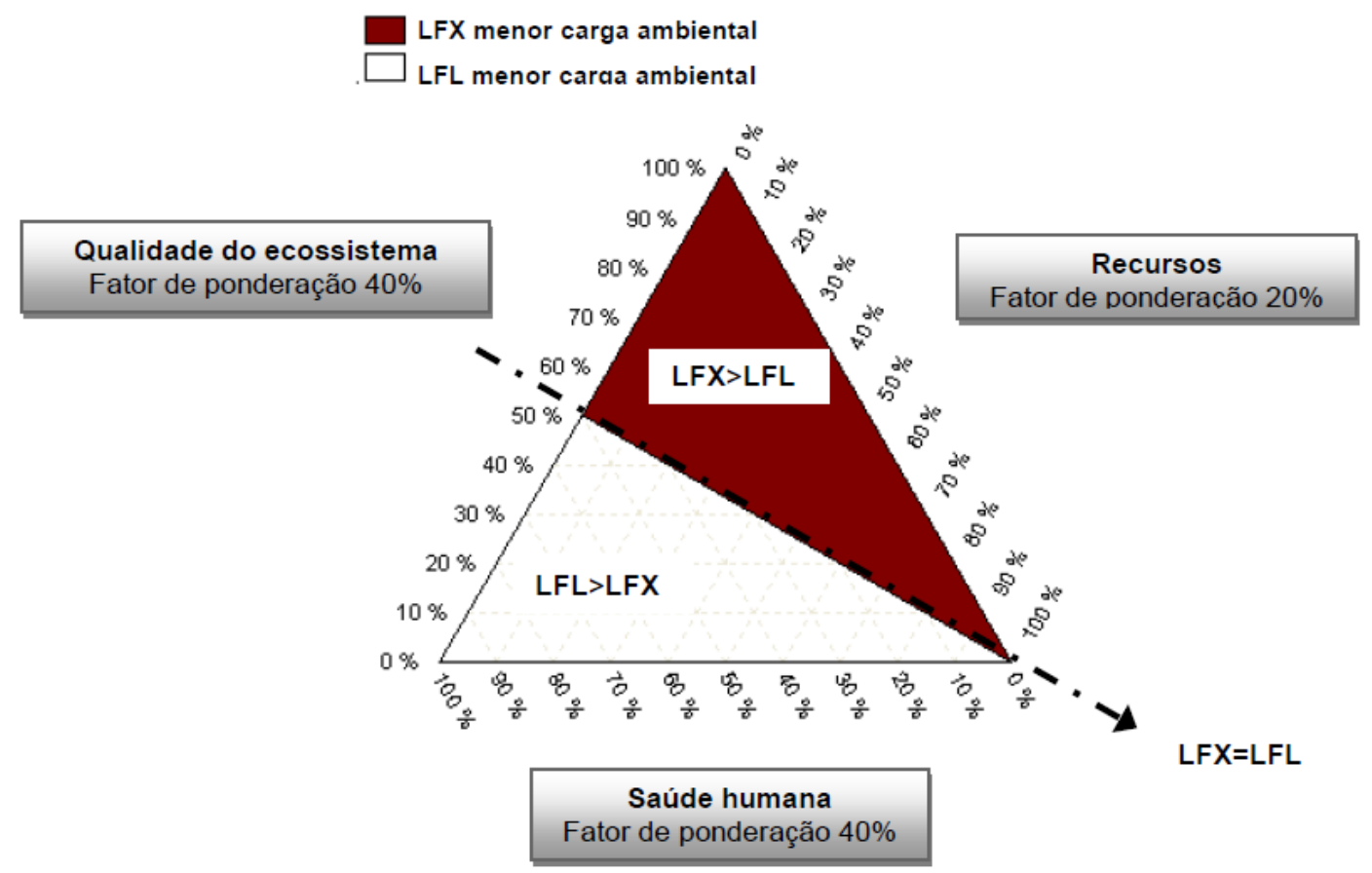

Figura 6.12 - Comparação do desempenho ambiental entre o sistema de gaseificação LFX e o LFL.

Conforme observado anteriormente, o leito fixo apresenta, relativamente, uma menor carga ambiental em relação aos danos à saúde humana, enquanto o leito fluidizado apresenta um melhor desempenho no que se refere aos danos à qualidade do ecossistema. A linha de indiferença indica a categoria de dano (recursos minerais e combustíveis fósseis) em que ambos os sistemas apresentam o mesmo perfil.

No que tange a aplicação destes dois sistemas para uma futura produção de hidrogênio, o monóxido de carbono obtido na gaseificação pode ser convertido em hidrogênio adicional pela reação shift água-gás. Posteriormente, o hidrogênio pode ser separado do dióxido do carbono pelo processo Pressuring Swing Adsorption (PSA), resultando em um hidrogênio 99,9\% puro (BAIN\&CRAIG, 2005) para aplicação direta em células de baixa temperatura.

Segundo os dados do estudo realizado por Hammelinck \& Faaij $(2001)^{8}$, a média estimada de produção de hidrogênio via gaseificação da biomassa é de 10,49

\footnotetext{
8 Este autor examinou gaseificadores diretos e indiretos, pressurizados e atmosféricos, com diversas configurações de limpeza do syngas e separação do hidrogênio (apud SPATH \& DAYTON, 2003.).
} 
t/dia para cada 1 tonelada de alimentação diária de biomassa, o que corresponde a 1,25 TJ/dia ${ }^{9}$, com base no poder calorífico inferior do hidrogênio $(\mathrm{MJ} / \mathrm{kg})$.

Neste sentido, considerando a alimentação da biomassa (base úmida) nos dois sistemas, a estimativa de produção de hidrogênio para as plantas de gaseificação modelada é de $176 \mathrm{t}$ de $\mathrm{H}_{2} /$ dia $\left(21 \mathrm{TJ}\right.$ ) para o LFX, e de $162 \mathrm{t}$ de $\mathrm{H}_{2} /$ dia (19 TJ) para LFL.

Neste quadro, é importante destacar:

I) Se por um lado a composição do syngas produzido pela planta de leito fixo apresenta um maior percentual de $\mathrm{H}_{2}$ (20\% a mais), por outro, o poder calorífico do gás produzido é menor $\left(5,2 \mathrm{MJ} / \mathrm{Nm}^{3}\right)$ do que o leito fluidizado $\left(5,4 \mathrm{MJ} / \mathrm{Nm}^{3}\right)$.

II) O leito fluidizado tem uma eficiência de conversão da biomassa maior do que leito fixo, ou seja, um menor consumo deste recurso para a mesma capacidade de produção de energia. Tal eficiência refletiu em cerca de menos $6 \%$ de demanda acumulada de energia, enquanto o tempo de retorno de investimento em energia é praticamente igual ao leito fixo.

III) Não obstante, em relação à contribuição dos danos a saúde, o leito fixo apresenta um perfil similar ao leito fluidizado (apenas $1 \%$ a mais) e, no que se refere à qualidade do ecossistema, a carga ambiental é15\% menor do que leito fluidizado.

IV) Especificamente em relação aos impactos de maior magnitude (notoriamente os relacionados à saúde humana), os danos causados pelos efeitos respiratórios apresentam uma escala de abrangência regional e local, enquanto no que se refere às mudanças climáticas, embora as emissões modeladas considerem o contexto europeu, os danos causados pelas emissões são de escala global.

No panorama geral, considerando os parâmetros de análise aqui utilizados, observa-se que para a mesma capacidade de produção de energia (1 MW), o sistema de gaseificação de leito fluidizado apresenta um melhor desempenho do

\footnotetext{
${ }^{9}$ Poder calorífico inferior do hidrogênio: $120 \mathrm{MJ} / \mathrm{kg}$.
} 
que o leito fixo, sendo mais recomendável para uma futura aplicação na produção de hidrogênio.

Todavia, se analisamos os impactos ambientais regionais e locais e as características do syngas gerado (principalmente em função do conteúdo de $\mathrm{H}_{2}$ ), a produção de energia via conversão da biomassa pelo leito fluidizado é menos favorável do que o leito fixo. Neste caso, as condições do local (ou região) da área de implementação da planta de gaseificação, como por exemplo, aspectos demográficos, características dos ecossistemas de entorno, restrições ambientais legais, disponibilidade de recursos, entre outros pertinentes, são importantes fatores que podem pesar sob esta análise.

Tais considerações, por sua vez, enfatiza a necessidade de estudos futuros não só relacionados aos critérios acima, como também da integração dos demais processos necessários para a produção do hidrogênio aos sistemas de gaseificação estudados.

Não obstante, destaca-se que a avaliação do ciclo de vida das plantas de gaseificação de leito fixo e leito fluidizado permitiu visualizar a relação das variáveis operacionais (como por exemplo, consumo de recursos e eficiência de conversão), com o desempenho energético (demanda acumulada de energia e tempo de retorno de investimento) e ambiental dos sistemas (quantidades de emissões, tipos de danos).

Por fim, as informações inventariadas sobre o consumo de materiais e energia, bem como a identificação e tipos de impactos dos sistemas de gaseificação aqui estudados, podem direcionar os esforços em Pesquisa e Desenvolvimento, auxiliar na execução de análises econômicas e, consequentemente, identificar a necessidade de investimentos futuros. 


\subsection{SISTEMA DE ENERGIA SOLAR FOTOVOLTAÍCA}

\subsubsection{Objetivo, escopo e unidade funcional}

Similarmente à ACV dos sistemas de gaseificação aqui estudados, o objetivo da avaliação é identificar e comparar o desempenho ambiental e o energético de uma planta fotovoltaica (FV), considerando os mesmos parâmetros de análise ( CED e EPBT) e a metodologia de impactos ( Eco-indicador 99).

Para a modelagem do sistema FV foram utilizadas como referência de análise, a tecnologia de silício monocristalino, o tipo de instalação (grounded monted) e a potência instalada $\left(1 \mathrm{MW}_{\mathrm{P}}\right)$, dentre as principais características da planta de energia solar da Universidade da Califórnia - Merced (Figura 13).

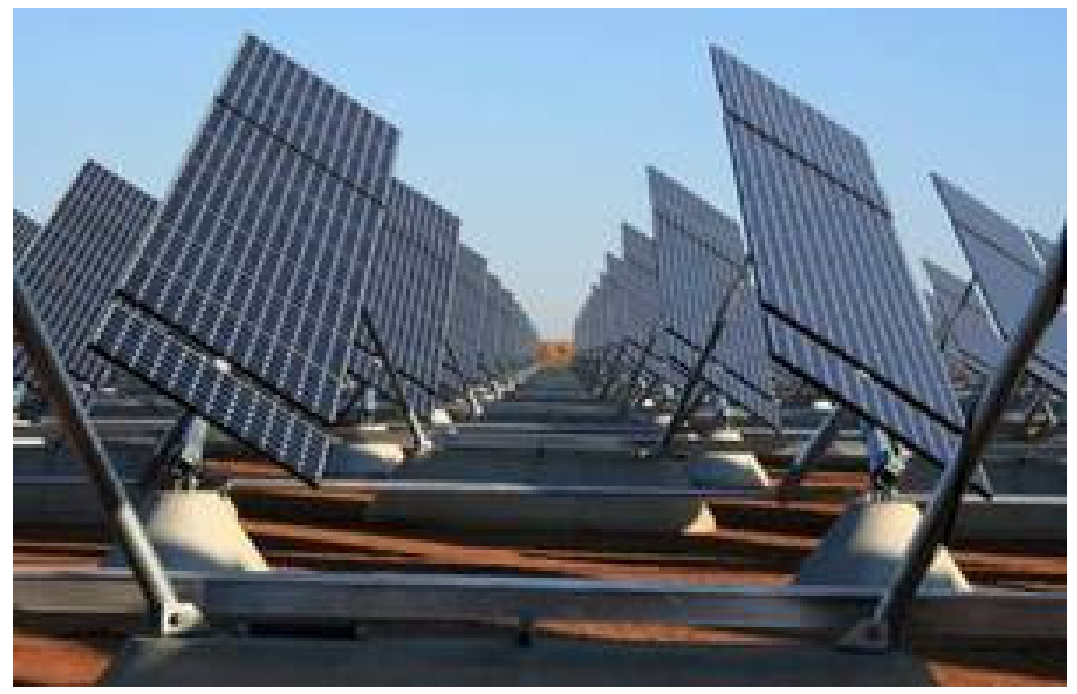

Figura 6.13 - Planta Solar Fotovoltaica de $1 \mathrm{MW}$ da Universidade da Califórnia - UC Merced (2009).

Conforme apresentado na metodologia, no que tange às condições climáticas e a eficiência do sistema adotou-se, respectivamente, a média de irradiação solar no Brasil e o performance ratio estimado pela IEA (Cf. cap. 3).

No sistema fotovoltaico modelado, a capacidade de geração de energia de 1 $\mathrm{MW}_{\mathrm{P}}$ corresponde a $1 \mathrm{MW}_{\mathrm{El}}$ sob condições padrões de teste ${ }^{10}$. Cada módulo possui $98,6 \mathrm{~cm}$ de largura e $162 \mathrm{~cm}$ de altura e uma potência de $224 W_{P}$, sendo a área total de incidência de irradiação (plano coletor) estabelecida para o estudo de $6730 \mathrm{~m}^{2}$.

\footnotetext{
${ }^{10}$ Comumente, em sistemas FV, a unidade $\mathrm{kWp}$ (kilowatt pico) é utilizada para referenciar a potência nominal (ou instalada) e esta representa a capacidade máxima de saída de energia do módulo FV sob condições padrões de teste $\left(1000 \mathrm{~W} / \mathrm{m}^{2}\right.$ de irradiação solar a $25^{\circ} \mathrm{C}$ de temperatura e espectro solar de massa do ar AM=1,5).
} 


\section{RESULTADOS E DISCUSSÕES}

Geralmente, um sistema fotovoltaico é constituído por módulos (ou arranjos) e elementos de suporte denominados balance of system (BOS). O BOS compreende as estruturas nos quais os módulos são fixados e orientados em direção ao sol, além de componentes que transportam (cabos) e convertem (inversor) a corrente contínua (DC) em corrente alternada (AC) (Figura 6.14).

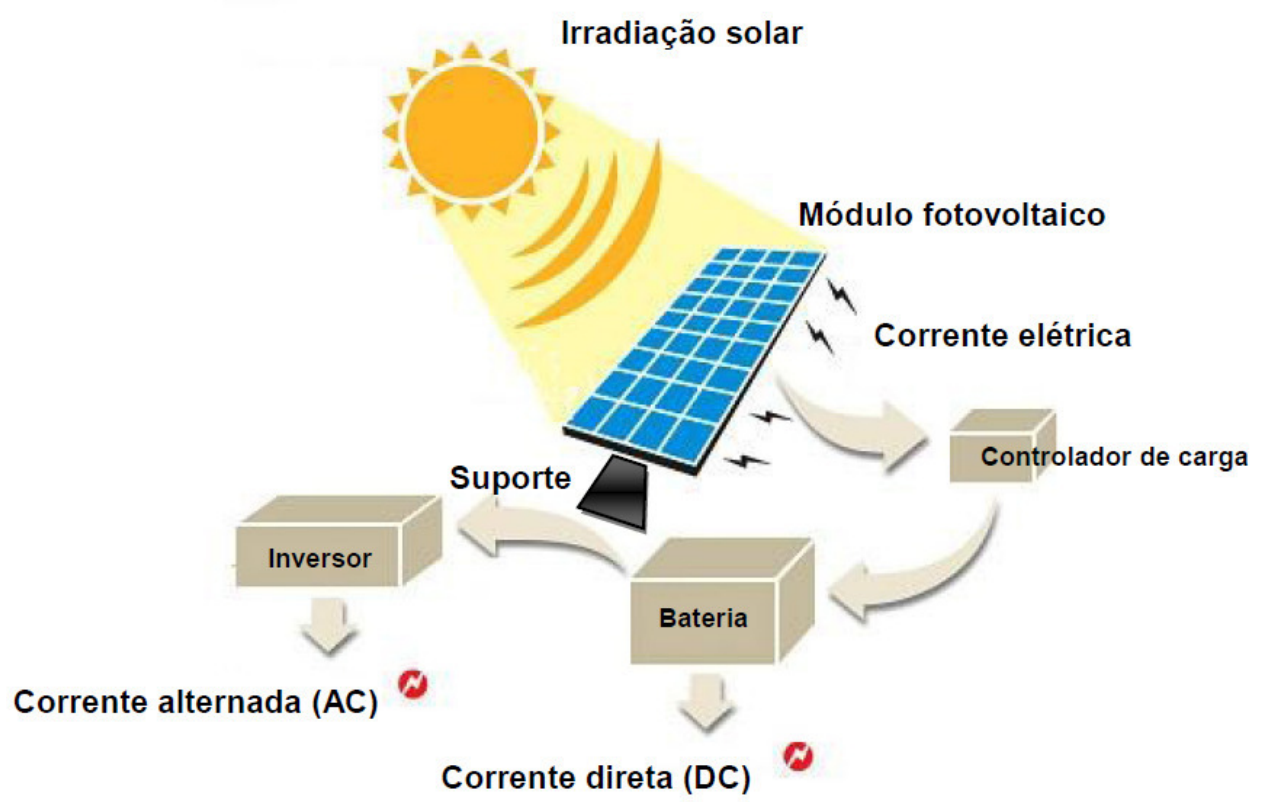

Figura 6.14 - Diagrama simplificado de um sistema de energia solar fotovoltaico (modificado a partir de Sumco Corporation, 2010).

Tipicamente, um determinado número de células solares são montadas em um módulo com área de 1.0 a $2 \mathrm{~m}^{2}$. Uma lâmina de vidro-plástico encapsula as células e, na maioria dos casos, uma moldura de alumínio é adicionada no módulo. O conjunto de células perfaz um módulo e o conjunto de módulos o painel. Por fim, o conjunto de painéis compõe o arranjo fotovoltaico (Figura 6.15).
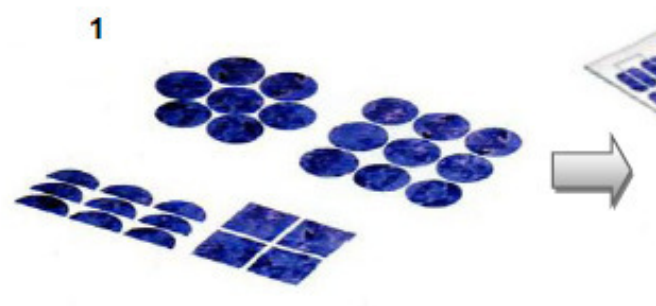

2
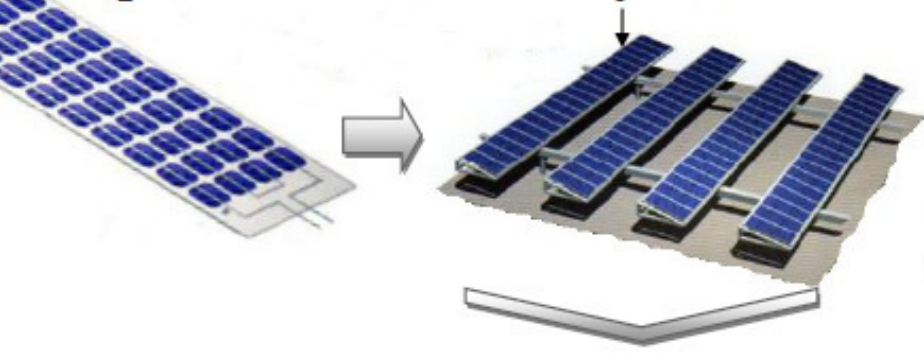

4

Figura 6.15 - Diagrama ilustrando a relação entre as células (1) o módulo (2), painel (3) e o arranjo (4) do sistema FV (modificado a partir de PRASAD \&SNOW,2005). 
Destaca-se que, para evitar possíveis confusões quanto ao termo módulo, adotou-se a nomenclatura utilizada no inventário do Ecoinvent (painel) para o processo produtivo dos módulos. De acordo com Jungbluth (2005), a expressão painel é, comumente, utilizada nos estudos de ACV de sistemas FV para se referir ao módulo, principalmente em aplicações domésticas (telhado).

Tal como nos sistemas de gaseificação, a unidade funcional estabelecida para o propósito do estudo é de $1 \mathrm{MW}^{11}$ e, conforme Held \& Shibasaki (2008), para fins comparativos, também utiliza-se o equivalente de energia em MJ. Para a avaliação do ciclo de vida do sistema FV, o escopo do estudo incluiu, além do estágio de geração de energia, os seguintes processos de produção dos componentes do sistema FV (Figura 6.16):

I. A produção mix de silício purificado (PM) para indústria $F V$, no qual considera-se que cerca de $80 \%$ do fornecimento de silício purificado é produzido pelo método Siemens modificado e, $20 \%$, é oriundo da matéria prima de lâminas de silício OG - off grade e de EG - eletronic grade (refugo da indústria de microeletrônica).

II. A produção de silício monocristalino (Si-sc), cujo inventário compreende o transporte do silício até a fábrica, bem como as demais entradas do processo (método Czochralski - CZ). Destaca-se que os dados dos materiais e outros insumos se limitam apenas aos portões de saída e entrada da fábrica.

III. A produção de lâminas (PL), que abrange o consumo de energia, água e matéria-prima, além dos tratamentos necessários dos resíduos produzidos dentro da fábrica.

IV. A produção de células solares (CS), de dimensões $156 \times 156 \mathrm{~mm}^{2}$. O inventário também compreende os processos de limpeza e polimento e os dados do processo abarcam o consumo de insumos, eletricidade e tratamento de resíduos na fábrica.

V. A produção dos inversores (IN), no qual estão inclusos o consumo dos principais materiais, eletricidade, transporte e tratamento de resíduos.

\footnotetext{
11 Similar ao sistemas de gaseificação, adotou-se a nomenclatura MW para referir-se a MW $\mathrm{El}_{\mathrm{El}}$.
} 
VI. A produção de painéis solares (PS): abrange, entre outros a produção do vidro, alumínio, cobre e etil vinilacetato (EVA) na fabricação do módulo, além dos tratamentos dos resíduos produzidos.

Os dados do inventário da produção de lâminas, células e módulos incluem a infraestrutura necessária para a construção da fábrica e descomissionamento das mesmas, bem como o transporte de materiais.

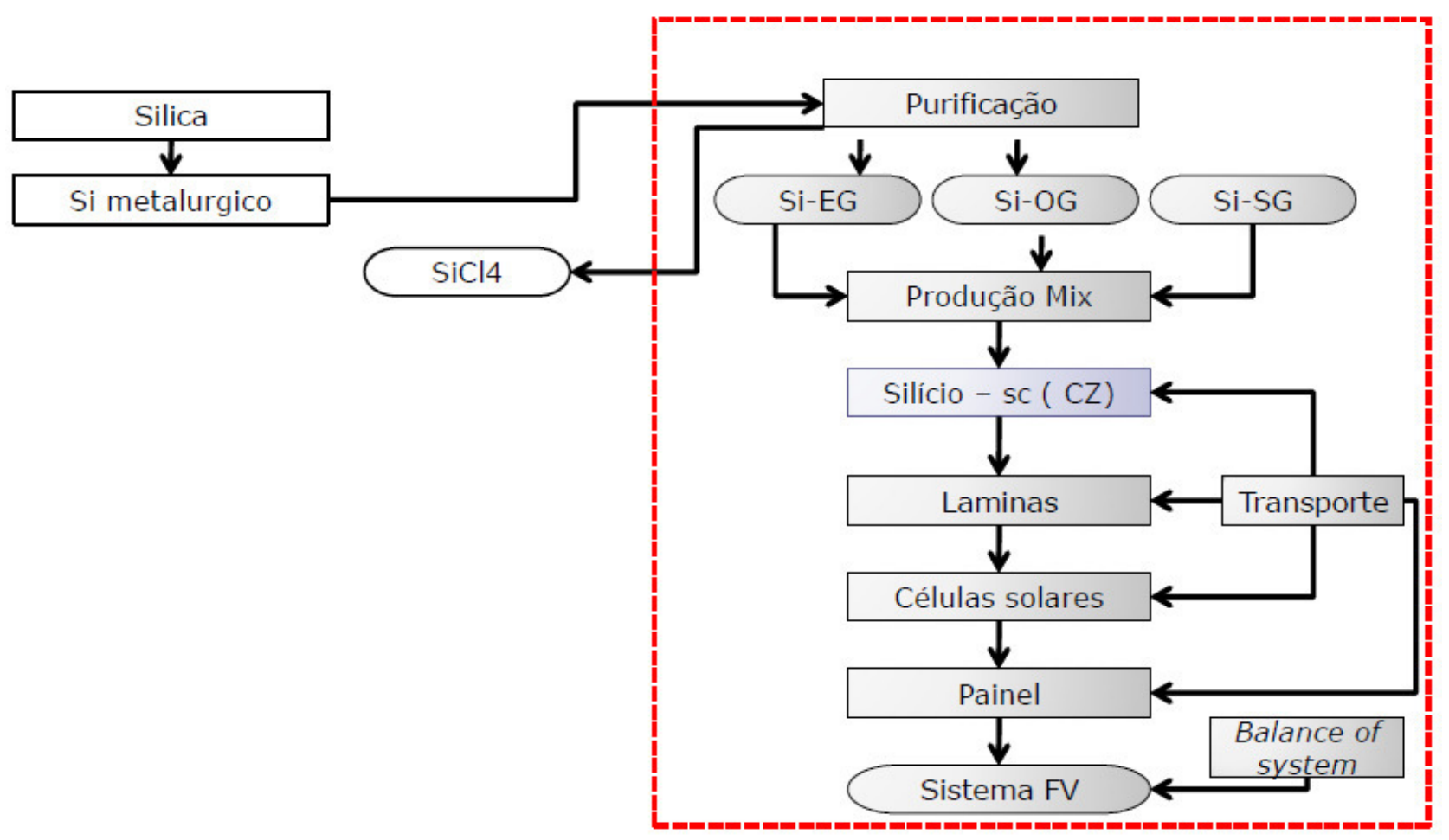

Figura 6.16- Diagrama simplificado dos processos incluídos nos limites do sistema de energia solar fotovoltaico estudado.

Dentre os principais componentes do BOS do sistema FV, somente os cabos (exceto os de conexão com a rede) e os inversores estão inclusos na análise. $O$ inversor considerado nesta avaliação e, utilizado por vários tipos de tecnologia ${ }^{12}$, possui a capacidade de $2500 \mathrm{~W}$. O tempo de vida útil estimado para a planta é de 30 anos. Igualmente aos sistemas de gaseificação, os processos subsequentes de produção de hidrogênio não foram incluídos no escopo da análise.

Além das informações disponibilizadas na literatura e em contatos pessoais, os elementos do inventário das etapas de produção do sistema FV modelado

\footnotetext{
12 O modelo Sunmaster 2500 inventariado no Ecoinvent V.2.01não se encontra mais disponível no mercado. O fabricante (Mastervolt) substituiu-o pelos modelos Sunmaster QS 2000 e Sunmaster QS 3200, que apresentam capacidades comparáveis ao modelo 2500 (Cf. Wild-Scholten, 2006).
} 
baseou-se, majoritariamente, nos dados do Ecoinvent $v$ 2.0, no qual, tanto a tecnologia FV de silício monocristalino, quanto multicristalino, foram recentemente atualizados.

Cabe ressaltar que, embora a indústria fotovoltaica esteja crescendo rapidamente e novas tecnologias vem sendo desenvolvidas, particularmente as células de Si-sc ainda dominam o mercado em conjunto com as de Si-mc. Mesmo diante do leve recuo da sua participação no mercado, este tipo de célula ainda permanecerá no futuro como uma importante tecnologia (FUKUROZAKI et. al., 2010).

\subsubsection{Inventário}

Embora alguns processos da cadeia produtiva da indústria $\mathrm{FV}$ ainda apresentem restrições quanto à disponibilidade e uso de dados (principalmente em função do sigilo industrial), em contraste com a disponibilidade de informações observada em relação aos dos sistemas de gaseificação, há uma vasta quantidade de processos inventariados disponíveis do sistema $\mathrm{FV}^{13}$.

\subsubsection{Produção mix de silício purificado - silício off grade (OG), grau eletrônico (EG) e grau solar (SG)}

No inventário deste processo, a maioria dos principais fluxos e seus valores está relacionada ao consumo de energia e a entrada de silício. O fluxo de referência é $\mathrm{kg}$ de silício purificado, sendo 5,2\% de silício EG e OG, 14,6 \% somente de EG e $80,2 \%$ de SG (processo Siemens modificado). O total produzido, necessário para produção das células utilizadas no sistema $F V$, foi de $6092 \mathrm{~kg}$. A tabela 6.12 apresenta os dados das unidades de processo de silício purificado.

Geralmente, para a obtenção do Si-EG realiza-se a deposição química a partir da fase de vapor do triclorosilano com hidrogênio, em reatores do tipo-U, em que filamentos de silício, montados em um arranjo na forma de ponte, são aquecidos por corrente elétrica a uma temperatura entre 1000 e $1100{ }^{\circ} \mathrm{C}$. Este é o comumente chamado processo Siemens e o silício (silício policristalino) obtido por este método e por outros similares apresenta um teor máximo de impurezas de até 0,001 ppm.

\footnotetext{
13 Todavia, ressalta-se que algumas das informações contidas no banco de dados, utilizadas no estudo, apresentam dados confidenciais (protegidos), onde não é possível determinar com precisão entradas e saídas específicas de algumas unidades básicas dos processos, uma vez que os valores se encontram agregados
} 
Tabela 6.12 - Dados (brutos) das unidades de processo da produção mix de silício purificado com respectivas quantidades e unidades de medidas.

\begin{tabular}{lccc}
\hline & Produção Mix de Silicio Purificado (na planta) & & \\
& & & \\
Processo, infraestrutura ou atividade & Quantidade & $\begin{array}{c}\text { Unidade de } \\
\text { medida }\end{array}$ & Fluxo \\
Silicio, grau solar, processo Siemens modificado, na planta & $4,9 \mathrm{E} 003$ & $\mathrm{~kg}$ & Input \\
Silicio, grau eletrônico, na planta & $8.9 \mathrm{E} 002$ & $\mathrm{~kg}$ & Input \\
Silicio, grau eletrônico, off grade, na planta & $3,2 \mathrm{E} 002$ & $\mathrm{~kg}$ & Input \\
Emissóes de $\mathrm{CO}_{2 \text { equvalente }}$ & $2.9 \mathrm{E} 005$ & $\mathrm{~kg}$ & Output \\
Massa final de silicio purificado & $6.9 \mathrm{E} 003$ & $\mathrm{~kg}$ & Output \\
\hline
\end{tabular}

Para a produção de silício grau solar, utilizado na indústria fotovoltaica, não é necessário atingir pureza tão elevada ${ }^{14}$ como a do Si-EG. Entretanto, dada a ausência de processos adequados para a obtenção de um silício grau solar específico para a conversão fotovoltaica, emprega-se o mesmo material consumido pelo setor de microeletrônica.

Tal prática esbarra nos altos preços de SI-EG. Como forma de redução destes custos, os produtores de células solares consomem, em parte, rejeitos da produção de Si-EG que não atingem a pureza exigida para os componentes microeletrônicos. Presentemente, existem processos alternativos para produção de silício grau solar, por meio de um processo similar ao Siemens, denominado Siemens modificado.

Conforme Jungbluth (2005), nos dias atuais a maioria do silício utilizado pela indústria PV é produzido por meio do processo Siemens modificado. Do ponto de vista da ACV, a mais importante diferença entre os dois processos Siemens, consiste na redução do consumo de energia do método modificado em relação ao processo padrão, visto que há uma flexibilidade maior no grau de pureza.

\subsubsection{Silício monocristalino}

Uma vez obtido o silício puro, é necessário obter-se o silício monocristal utilizando-se, para esse fim, o método Czochralski (CZ) (Figura 6.17). O método consiste em introduzir uma semente monocristalina em silício fundido, baixando então lentamente a temperatura para que se dê a cristalização, por exemplo, pelo método de Fusão Zonal Flutuante (FZ).

\footnotetext{
${ }^{14}$ O silício de grau solar apresenta uma concentração de impurezas de 0,01ppm.
} 


\section{RESULTADOS E DISCUSSÕES}

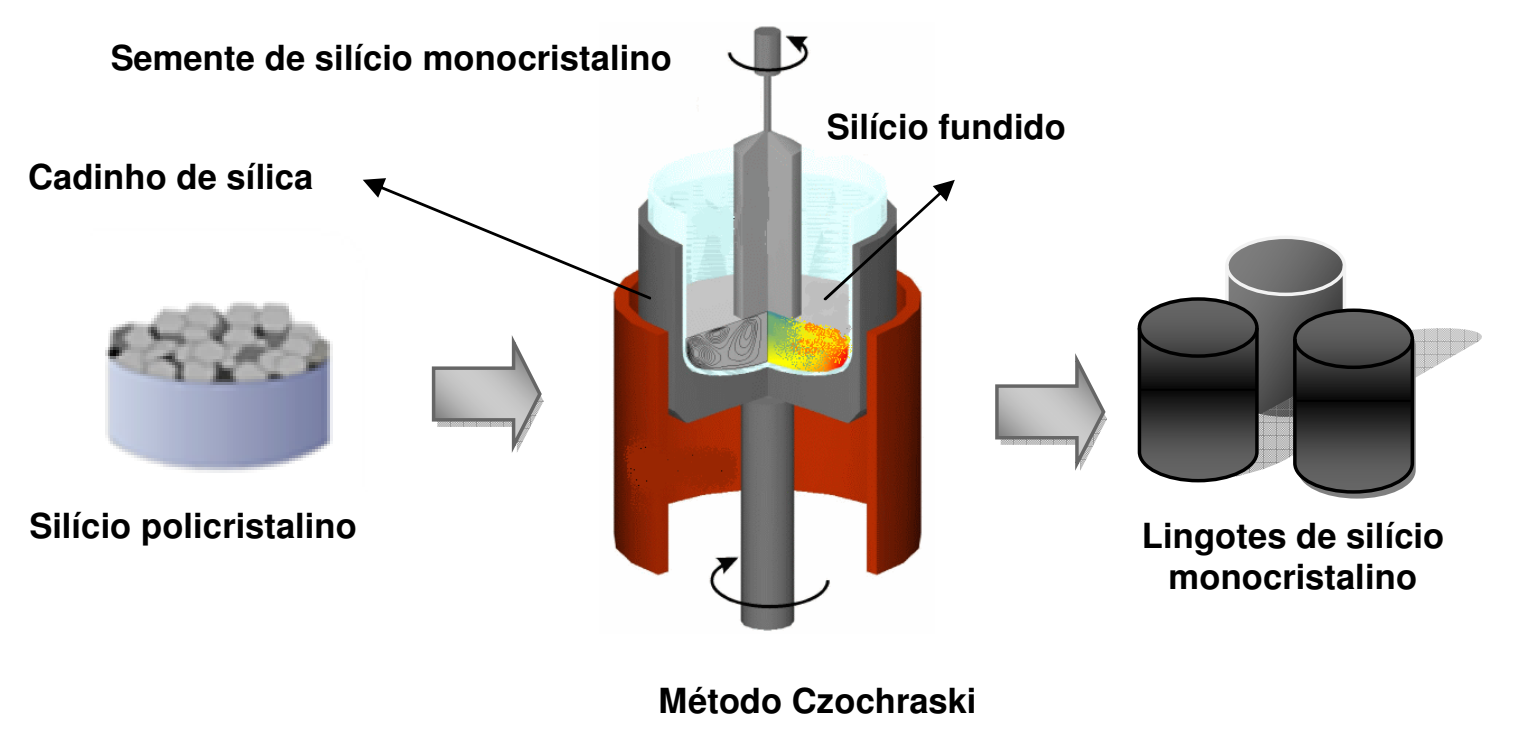

Figura 6.17 - Diagrama simplificado do processo de produção do silício monocristalino pelo método Czochralski (FUKUROZAKI, 2011).

Os dados do inventário estão baseados na literatura e em relatórios ambientais de fabricantes. De acordo com Wild-Scholten \& Alsema (2007), 0 consumo de energia estimado na purificação (método CZ) é de 85,6 kWh/kg, no caso do silício utilizado na indústria fotovoltaica e, de $200 \mathrm{kWh} / \mathrm{kg}$ para o setor de eletrônicos.

O processo modelado produz lingotes de silício com diâmetro $130 \mathrm{~mm}$ e comprimento de $150 \mathrm{~cm}$ e o fluxo de referência é $\mathrm{kg}$ de silício monocristalino. O total produzido e necessário para fabricar a quantidade de células requeridas para 0 painel foi de $6451 \mathrm{~kg}$. A tabela 6.13 apresenta os dados brutos das unidades de processo da produção do silício monocristalino.

\subsubsection{Produção de lâminas}

Os processos incluídos no estudo envolvem a usinagem, corte, desbaste, limpeza e polimento das lâminas. Em síntese, os lingotes (colunas) de Si-sc são cortados em quadrados com uma seção diagonal determinada pelo tamanho final almejado para a célula solar.

Em seguida, estas colunas são fatiadas em lâminas extremamente finas. Após esse processo, as lâminas são limpas e polidas com diferentes produtos químicos, tais como, entre outros, $\mathrm{KOH}$ ou $\mathrm{NaOH}$, ácido clorídrico e ácido acético. $\mathrm{O}$ polimento visa assegurar às propriedades ópticas e elétricas da célula solar (Figura 6.18). 

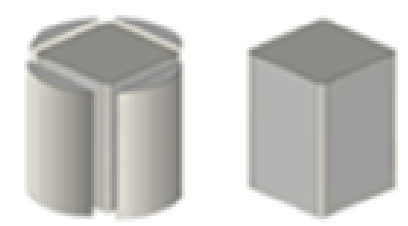

Fresa dos lingotes de silício

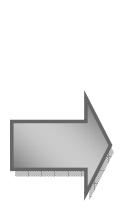
(1) .

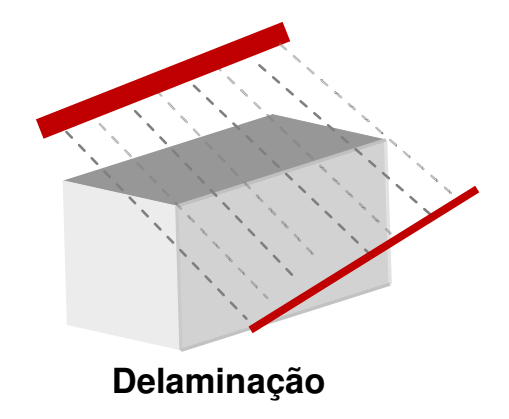

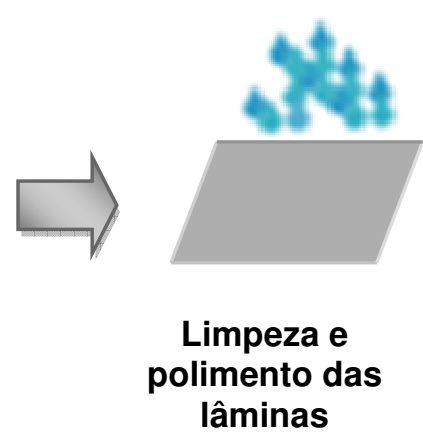

Figura 6.18 - Diagrama simplificado do processo de produção de lâminas de silício monocristalino (FUKUROZAKI, 2011).

Destaca-se que, na delaminação, o carbeto de silício e o trietileno glicol utilizados nesta etapa, são reciclados e reutilizados na indústria fotovoltaica. Assume-se que a espessura da lâmina seja de 270 mícrons e o peso é de $629 \mathrm{~g} / \mathrm{m}^{2}$.

O fluxo de referência deste processo de produção de lâminas é $\mathrm{m}^{2}$ de superfície da lâmina e o montante produzido para o sistema FV modelado foi de $6002 \mathrm{~m}^{2}$. No inventário deste processo estão inclusas as perdas de material não reciclado devido à delaminação. A tabela 6.14 , apresenta as unidades de processo utilizadas na produção das lâminas. 
Tabela 6.13 - Dados das unidades de processo da produção de silício monocristalino (método CZ) e respectivas referências de quantidades.

\begin{tabular}{|c|c|c|c|}
\hline \multicolumn{4}{|c|}{ Produção de Silício Monocristalino, Método Czochralski (Si-sc/CZ) } \\
\hline Unidade básica & Quantidade & $\begin{array}{l}\text { Unidade de } \\
\text { medida }\end{array}$ & Fluxo \\
\hline Silício purificado (produção mix) & $6,9 \mathrm{E} 003$ & $\mathrm{~kg}$ & Input \\
\hline Acetona, líquida, na planta & $3,2 \mathrm{E} 002$ & $\mathrm{~kg}$ & Input \\
\hline Ácido nítrico, $50 \% \mathrm{H}_{2} \mathrm{O}$, na planta & $6,1 \mathrm{E} 002$ & $\mathrm{~kg}$ & Input \\
\hline Planta industrial de silício & $6,5 \mathrm{E}-008$ & pcs & Input \\
\hline Ácido acético, $98 \% \mathrm{H}_{2} \mathrm{O}$, na planta & $7,0 \mathrm{E} 002$ & $\mathrm{~kg}$ & Input \\
\hline Água, no local do usuário. & $6,1 \mathrm{E} 005$ & $\mathrm{~kg}$ & Input \\
\hline Hidróxido de cálcio, hidratado, embalado, na planta & $1,2 \mathrm{E} 003$ & $\mathrm{~kg}$ & Input \\
\hline Argônio, líquido, na planta & 3,7 E004 & $\mathrm{kg}$ & Input \\
\hline Revestimento de cerâmica, no estoque regional & $2,2 \mathrm{E} 003$ & $\mathrm{~kg}$ & Input \\
\hline Fluoreto de hidrogênio & $3,3 \mathrm{E} 002$ & $\mathrm{~kg}$ & Input \\
\hline Hidróxido de sódio, $50 \% \mathrm{H}_{2} \mathrm{O}$, produção mix, na planta & 2,7 E002 & $\mathrm{kg}$ & Input \\
\hline Eletricidade, média voltagem, produção UCTE, na rede & $2,0 \mathrm{E} 006$ & MJ & Input \\
\hline Gás natural, queimado em forno industrial, baixo $\mathrm{NOx},>100 \mathrm{~kW}$ & 4.4 E005 & MJ & Input \\
\hline Transporte de bens, trem & 2.6 E004 & $\mathrm{tkm}$ & Input \\
\hline Transporte, carreta, $16 \mathrm{t}$, média da frota & 1,1 E004 & tkm & Input \\
\hline Disposição, resíduos, silício da produção de lâminas, inorgânicos, $9,4 \%$, para materiais residuais & $2.3 \mathrm{E} 004$ & $\mathrm{~kg}$ & Input \\
\hline Emissões de $\mathrm{CO}_{2}$ equivalente & 4,0 E005 & $\mathrm{kg}$ & Output \\
\hline Massa final & $6,5 \mathrm{E} 003$ & $\mathrm{~kg}$ & Output \\
\hline
\end{tabular}


Tabela 6.14 - Dados das unidades de processo da produção de lâminas de silício monocristalino e respectivas referências de quantidades.

\begin{tabular}{|c|c|c|c|}
\hline \multicolumn{4}{|c|}{ Produção de Lâminas de Silício Monocristalino ( L/Si-sc) } \\
\hline Unidade básica & Quantidade & $\begin{array}{l}\text { Unidade de } \\
\text { medida }\end{array}$ & Fluxo \\
\hline Silício monocristalino, método $\mathrm{CZ}$ & $6,5 \mathrm{E} 003$ & $\mathrm{~kg}$ & Input \\
\hline Carbeto de silício, na planta & 2,9 E003 & $\mathrm{kg}$ & Input \\
\hline Carbeto de silício, reciclagem na planta & $1,3 \mathrm{E} 004$ & $\mathrm{~kg}$ & Input \\
\hline Fábrica de lâminas & 0,024 & pcs & Input \\
\hline Dipropileno glicol monometil éter, na planta & $1,8 \mathrm{E} 003$ & $\mathrm{~kg}$ & Input \\
\hline Água, no local do usuário. & 36 & $\mathrm{~kg}$ & Input \\
\hline Trietileno glicol, na planta & $6,6 \mathrm{E} 002$ & $\mathrm{~kg}$ & Input \\
\hline Trietileno glicol, reciclagem, na planta & 1,6 E004 & $\mathrm{kg}$ & Input \\
\hline Ácido Hidroclorídrico, $30 \% \mathrm{H}_{2} \mathrm{O}$, na planta & 16 & $\mathrm{~kg}$ & Input \\
\hline Sulfonato de alquibenzeno, linear, petroquímico, na planta & $31,4 \mathrm{E} 003$ & $\mathrm{~kg}$ & Input \\
\hline Hidróxido de sódio, $50 \% \mathrm{H}_{2} \mathrm{O}$, produção mix, na planta & 50 & $\mathrm{~kg}$ & Input \\
\hline Poliestireno, alto impacto, HIPS, na planta & $1,2 \mathrm{E} 003$ & $\mathrm{~kg}$ & Input \\
\hline Água, completamente macia, na planta & 3,9 E005 & $\mathrm{kg}$ & Input \\
\hline Papel, madeira livre,embalagem, no armazém & 60 & $\mathrm{~kg}$ & Input \\
\hline Filme de embalagem, LPDE, na planta & $6 \mathrm{E} 002$ & $\mathrm{~kg}$ & Input \\
\hline Lã de vidro, na planta & 60 & $\mathrm{~kg}$ & Input \\
\hline Furador acrílico, $34 \% \mathrm{H}_{2} \mathrm{O}$, & 12 & $\mathrm{~kg}$ & Input \\
\hline Cobre e zinco, na planta & 45 & $\mathrm{~kg}$ & Input \\
\hline Aço, liga, na planta & $8,9 \mathrm{E} 003$ & $\mathrm{~kg}$ & Input \\
\hline Wire drawing, aço & $8.9 \mathrm{E} 003$ & $\mathrm{~kg}$ & Input \\
\hline Eletricidade, média voltagem, produção UCTE, na rede & $1,7 \mathrm{E} 005$ & MJ & Input \\
\hline Gás natural, queimado em forno industrial, baixo NOx, $>100 \mathrm{~kW}$ & 2.4 E004 & MJ & Input \\
\hline Transporte de bens, trem & $2,5 \mathrm{E} 004$ & $\mathrm{tkm}$ & Input \\
\hline Transporte, carreta, $16 \mathrm{t}$, média da frota & $6,4 \mathrm{E} 003$ & tkm & Input \\
\hline Disposição, resíduos, produção de lâminas de silício, $0 \%$ de $\mathrm{H}_{2} \mathrm{O}$, para depósito no subsolo & $6.6 \mathrm{E} 002$ & $\mathrm{~kg}$ & Input \\
\hline Emissões de $\mathrm{CO}_{2}$ equivalente & $1,2 \mathrm{E} 005$ & $\mathrm{~kg}$ & Output \\
\hline Massa final & $6,9 \mathrm{EO} 03$ & $\mathrm{~kg}$ & Output \\
\hline
\end{tabular}




\subsubsection{Produção de células solares, painéis solares e inversores}

Em termos gerais, para a produção das células solares, as lâminas de Si-sc são inicialmente sujeitas a banhos químicos para remover os danos (irregularidades) na superfície e, posteriormente são dopadas (usualmente com fósforo e em um único lado) para criar as junções P-N ativas.

Posteriormente, uma impressão metálica (metalização serigráfica) é realizada em ambos os lados, com intuito de permitir a condução elétrica. Por fim, uma camada de cobertura anti-reflexo é colocada na face superior das células visando elevar a eficiência da célula. A figura 6.19 ilustra a produção da célula até a produção do painel fotovoltaico.

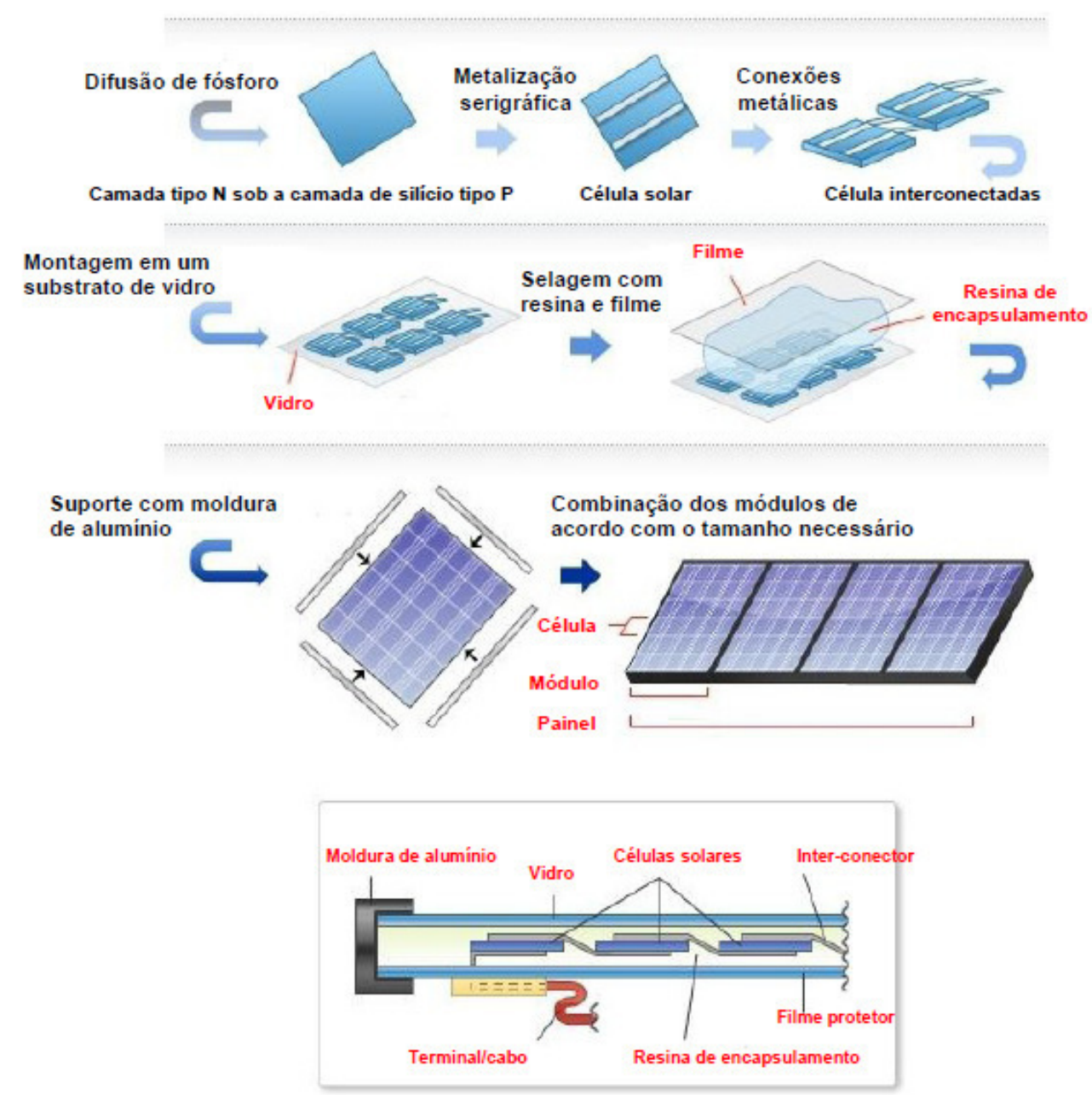

Figura 6.19 - llustração do processo de produção de células até a montagem do painel fotovoltaico e detalhado ampliado do painel (modificado a partir de Sumco Corporation, 2010)

A célula solar apresenta um tamanho final de $156 \times 156 \mathrm{~mm}^{2}\left(0,0243 \mathrm{~m}^{2}\right)$ e uma eficiência estimada de $15,4 \%$. O total produzido para compor o painel fotovoltaico 
utilizado no estudo foi de $6300 \mathrm{~m}^{2}$. As unidades de processo da produção das células são apresentadas na tabela 6.15 .

Para a produção de painéis fotovoltaicos, as células solares são, inicialmente, conectadas uma a outra por meio de conexões de cobre e embebidas em camadas de etil-venilacetato. Posteriormente, a parte posterior das células é coberta por um filme de Tedlar (poliéster e polivinilfluorado), enquanto uma película de vidro (glass low iron) é usada para cobrir a face superior.

Sequencialmente, as camadas são unidas sob pressão e calor, seguido pela limpeza das junções e isolamento das conexões. Por fim, uma moldura de alumínio tipo liga $\left(\mathrm{AlMg}_{3}\right)$ e uma conexão box são instaladas, formando assim os painéis. Cada painel (módulo) é composto por 60 células. $O$ fluxo de referencia é $\mathrm{m}^{2}$ de superfície de painel e o total produzido para o sistema fotovoltaico de $1 \mathrm{MW}$ foi de $6730 \mathrm{~m}^{2}$ (Tabela 6.16).

No que tange ao inversor (Figura 6.20), este consiste basicamente de transformadores, componentes da unidade de controle e conectores. A massa do inversor é de $18,5 \mathrm{~kg}$, com mais de $50 \%$ (kg/kg de aço) e $35 \%$ de transformadores.

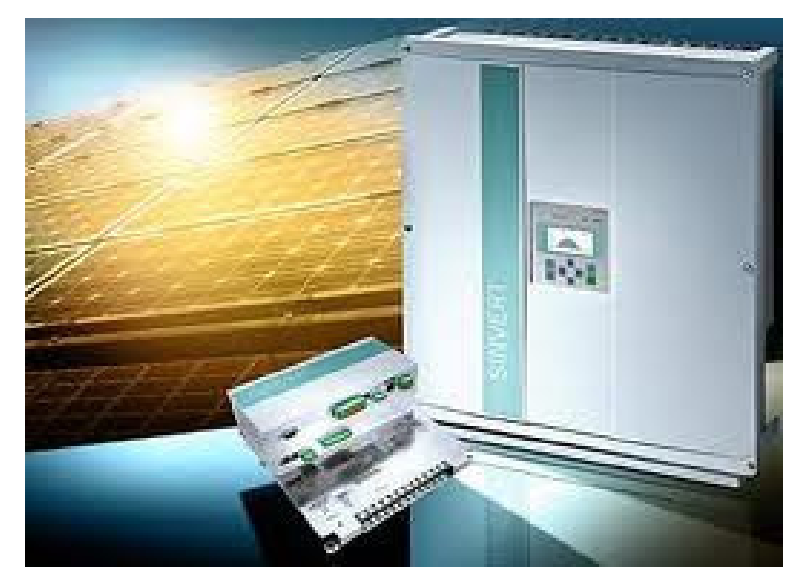

Figura 6.20 - Exemplo de inversor para plantas fotovoltaicas com geração de energia acima de $500 \mathrm{~kW}$ (Siemens, 2010)

De acordo com Schwarz \& Keller (1992), o consumo de eletricidade para montagem de inversor de $20 \mathrm{~kg}$ é de 22,0 kWh. No inversor estudado, o valor é de 21,2 $\mathrm{kWh} / \mathrm{kg}$ e a eficiência total é de $93,5 \%$. O consumo de embalagem e outros dados relacionados à montagem da estrutura protetora foram estimados a partir dos dados dos inversores de $500 \mathrm{~kW}$, encontrados na investigação realizado por Wild-Scholten (2006). Os dados brutos das unidades do processo de produção dos inversores são apresentados na tabela 6.17 . 
Tabela 6.15 - Dados das unidades de processo da produção das células solares de Si-sc e respectivas referências de quantidades.

Produção de Células Solares de Silício Monocristalino (CS/Si-sc)

\begin{tabular}{|c|c|c|c|}
\hline Unidade básica & Quantidade & $\begin{array}{l}\text { Unidade de } \\
\text { medida }\end{array}$ & Fluxo \\
\hline Lâminas de silício monocristalino & $6,0 \mathrm{E} 003$ & $\mathrm{~m}^{2}$ & Input \\
\hline Fabrica de células & 0,024 & pcs & Input \\
\hline Tetrafluoretileno, na planta & 18 & $\mathrm{~kg}$ & Input \\
\hline Amônia líquida, no estoque regional da loja & 38 & $\mathrm{~kg}$ & Input \\
\hline Pasta de metalização, face superior, na planta & 42 & $\mathrm{~kg}$ & Input \\
\hline Pasta de metalização, face inferior, alumínio, na planta & $4,1 \mathrm{E} 002$ & $\mathrm{~kg}$ & Input \\
\hline Pasta de metalização, face inferior, na planta & 25 & $\mathrm{~kg}$ & Input \\
\hline Cloreto de Cálcio, $\mathrm{CaCl}_{2}$, no estoque regional & $1,2 \mathrm{E} 002$ & $\mathrm{~kg}$ & Input \\
\hline Etanol a partir do etileno, na planta & 3,6 & $\mathrm{~kg}$ & Input \\
\hline Äcido fosfórico, fertilizante, $70 \% \mathrm{H}_{2} \mathrm{O}$, na planta & 43 & $\mathrm{~kg}$ & Input \\
\hline Isopropanol, na planta & $4,5 \mathrm{E} 002$ & $\mathrm{~kg}$ & Input \\
\hline Trietileno glicol, reciclagem, na planta & $1,6 \mathrm{E} 004$ & $\mathrm{~kg}$ & Input \\
\hline Solventes orgânicos, não especificado, na planta & 8,1 & $\mathrm{~kg}$ & Input \\
\hline Dióxido de titânio, produção, na planta & 0,008 & $\mathrm{~kg}$ & Input \\
\hline Ácido acético, $98 \% \mathrm{H}_{2} \mathrm{O}$, na planta & 16 & $\mathrm{~kg}$ & Input \\
\hline Agua, completamente mole, na planta & $7,8 \mathrm{E} 005$ & $\mathrm{~kg}$ & Input \\
\hline Cloreto de fósforo, na planta & 9 & $\mathrm{~kg}$ & Input \\
\hline Nitrogênio líquido, na planta & $1,4 \mathrm{E} 002$ & $\mathrm{~kg}$ & Input \\
\hline Oxigênio líquido, na planta & $5,8 \mathrm{E} 002$ & $\mathrm{~kg}$ & Input \\
\hline Produto silicone, na planta & 6,9 & $\mathrm{~kg}$ & Input \\
\hline Poliestireno expansível & 2,3 & $\mathrm{~kg}$ & Input \\
\hline Silicato de sódio,spray em pó, $80 \% \mathrm{H}_{2} \mathrm{O}$, na planta & $4,2 \mathrm{E} 002$ & $\mathrm{~kg}$ & Input \\
\hline Fluoreto de hidrogênio & $2,1 \mathrm{E} 002$ & $\mathrm{~kg}$ & Input \\
\hline Eletricidade, média voltagem, produção UCTE, na rede & $6,2 \mathrm{E} 005$ & MJ & Input \\
\hline
\end{tabular}




\begin{tabular}{|c|c|c|c|}
\hline \multicolumn{4}{|c|}{ Produção de Células Solares de Silício Monocristalino (CS/Si-sc) } \\
\hline Unidade básica & Quantidade & $\begin{array}{l}\text { Unidade de } \\
\text { medida }\end{array}$ & Fluxo \\
\hline Gás natural, queimado em forno industrial, baixo $\mathrm{NOx},>100 \mathrm{~kW}$ & 2.7 E004 & MJ & Input \\
\hline Öleo combustível leve, queimado em fonro industrial, $1 \mathrm{MW}$, não modular & $6,6 \mathrm{E} 003$ & MJ & Input \\
\hline Transporte de bens, trem & $8,6 \mathrm{E} 003$ & $\mathrm{tkm}$ & Input \\
\hline Transporte, carreta, $16 \mathrm{t}$, média da frota & $1,6 \mathrm{E} 003$ & tkm & Input \\
\hline Transporte transoceânico, bens, navio & 1,7E002 & tkm & Input \\
\hline Disposição, resíduos, produção de lâminas de silício, inorg. $9 \%$ de $\mathrm{H}_{2} \mathrm{O}$, para aterro & $1,6 \mathrm{E} 003$ & $\mathrm{~kg}$ & Input \\
\hline Tratamento, produção da célula FV, para estação de tratamento, classe 3 & $1,2 \mathrm{E} 003$ & $\mathrm{~m}^{3}$ & Input \\
\hline Emissões de $\mathrm{CO}_{2}$ equvalente & 1,4 E005 & $\mathrm{kg}$ & Output \\
\hline Ärea final & 6,3 E003 & $\mathrm{m}^{2}$ & Output \\
\hline
\end{tabular}

\section{Nota:}

1) O inventário do ciclo de vida deste processo é baseado principalmente na média de cinco empresas, elaborado por Wild-Scholten \& Alsema (2007) - Project Crystal Clear. Todas as empresas estudadas utilizam o processo de metalização serigráfica.

2) Algumas entradas e emissões são agregadas para proteger dados sensitivos. 


\section{Tabela 6.16 - Dados das unidades de processo da produção dos painéis solares de Si-sc e respectivas referências de quantidades.}

Produção de Painéis Fotovoltaicos de Silício Monocristalino (PV/Si-sc)

\section{Unidade básica}

Células de silício monocristalino Inversores

Vidro solar, baixo ferro,no estoque regional

Solda, livre de cádmio, na planta

Liga de alumínio, $\mathrm{AlMg}_{3}$, na planta

Oleo lubrificante, na planta

Plástico reforçado com fibra de vidro,poliamida, injeção de moldagem, na planta

Polietileno tereftalato, granulado, amorfo, na planta

Filme poliviniffluorado, na planta

Metanol, no estoque regional

Vinil acetato, na planta

1-propanol, na planta

Wire drawing, cobre

Cobre, no estoque regional

Acetona líquida, na planta

$\mathrm{H}_{2} \mathrm{O}$, no local do usuário

Niquel, na planta

Produto silicone, na planta

Vidro plano, temperado

Metanol, no estoque regional

Etilvinilacetato, alumínio, na planta

Placa corrugada, mix de fibra, simples divisão, na planta

Eletricidade, média voltagem, produção UCTE, na rede

Gás natural, queimado em forno industrial, baixo NOx, > 100kW

Transporte de bens, trem

Transporte, carreta, 16t, média da frota

Quantidade
6,3 E003
0,027
6,8 E004
59
1,8 E004
11
1,3 E003
2,5 E003
7,4 E002
15
11
55
7,6 E002
6,0 E002
87
1,4 E005
1,1
2,0 E002
6,1 E004
15
6,7 E003
7,4 E003
1,1 E005
3,6 E004
6,4 E004
1,1 E004

Fluxo

Input

Input

Input

Input

Input

Input

Input

input

Input

Input

Input

Input

Input

Input

Input

Input

Input

Input

Input

Input

Input

input

Input

Input

Input

Input 
Produção de Painéis Fotovoltaicos de Silício Monocristalino (PV/Si-sc)

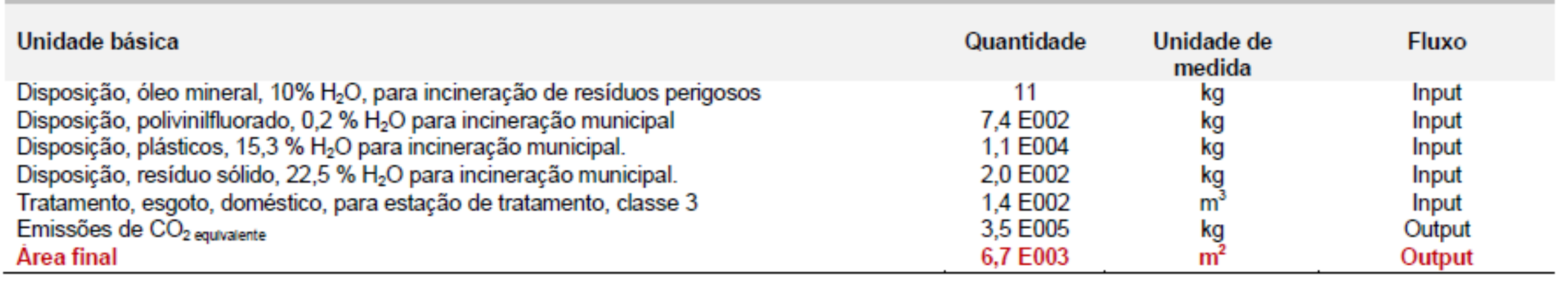

\section{Nota:}

1) Segundo Jungbluth (2005), o tamanho do painel e a quantidade de células podem variar significativamente entre diferentes produtores. Contudo no inventário do Ecoinvent, pequenas diferenças em relação à quantidade de células não são consideradas. 


\section{Tabela 6.17 - Dados das unidades de processo da produção dos inversores e respectivas referências de quantidades}

\section{Produção de Inversores (2500 W)}

\section{Unidade básica}

Capacitor, tantanlum, perfurado, na planta

Capacitor, filme, perfurado, na planta

Capacitor, tipo eletrolítico, $2 \mathrm{~cm}$ de $\mathrm{H}$, na planta

Diodo, não especificado, na planta

Wire drawing, cobre

Rolo, aço

Barra de extrusão seccionada, alumínio

Operação de fabricação, metal, calor a partir do carvão

Espuma fina de poliestireno

Alumínio, produção mix, na planta

Conector, grampo de conexão, na planta

Cobre, no estoque regional

Transistor, cabeado, pequeno tamanho, perfurado, na planta

Circuito integrado, IC, tipo lógico, na planta

Indutor, tipo anel de bracelete, na planta

Tecido, polietileno, na planta

Placa corrugada, mix de fibras, simples divisão, na planta

Placa de fiação impressa, perfurado, na planta

Resistor, tipo filme metálico, perfurando, na planta

Aço, elétrico, não especificado e de baixa liga, na planta

Operação de fabricação, metal, média de calor energético

Fábrica metalúrgica

Eletricidade, média voltagem, produção UCTE, na rede

Transporte de bens, trem

Transporte, carreta, 16t, média da frota

Transporte transoceânico, bens, navio

$\begin{array}{ccc}\text { Quantidade } & \begin{array}{c}\text { Unidade de } \\ \text { medida }\end{array} & \text { Fluxo } \\ 0,00095 & \mathrm{~kg} & \text { Input } \\ 0,00092 & \mathrm{~kg} & \text { Input } \\ 0,0061 & \mathrm{~kg} & \text { Input } \\ 0,0011 & \mathrm{~kg} & \text { Input } \\ 0,13 & \mathrm{~kg} & \text { Input } \\ 0,24 & \mathrm{~kg} & \text { Input } \\ 0,034 & \mathrm{~kg} & \text { Input } \\ 0,034 & \mathrm{~kg} & \text { input } \\ 0,0072 & \mathrm{~kg} & \text { Input } \\ 0,00024 & \mathrm{~kg} & \text { Input } \\ 0,0057 & \mathrm{~kg} & \text { Input } \\ 0,13 & \mathrm{~kg} & \text { Input } \\ 0,00091 & \mathrm{~kg} & \text { Input } \\ 0,0067 & \mathrm{~kg} & \text { Input } \\ 0,0084 & \mathrm{~kg} & \text { Input } \\ 0,0014 & \mathrm{~kg} & \text { Input } \\ 0,06 & \mathrm{~kg} & \text { Input } \\ 0,0054 & \mathrm{~m} & \text { Input } \\ 0,00012 & \mathrm{~kg} & \text { Input } \\ 0,24 & \mathrm{~kg} & \text { Input } \\ 0,00024 & \mathrm{~kg} & \text { Input } \\ 2,2 \mathrm{E}-010 & \mathrm{pcs} & \text { Input } \\ 1,8 & \mathrm{MJ} & \text { Input } \\ 0,17 & \mathrm{tkm} & \text { Input } \\ 0,055 & \mathrm{tkm} & \text { Input } \\ 0,97 & \mathrm{tkm} & \text { Input }\end{array}$




\section{Produção de Inversores $(2500 \mathrm{~W})$}

Unidade básica

Disposição, polietileno tereftalato, $0,2 \%$ de $\mathrm{H}_{2} \mathrm{O}$ para incineração municipal

Disposição, polietileno, $0,4 \%$ de $\mathrm{H}_{2} \mathrm{O}$ para incineração municipal

Disposição, embalagem de papelão, $19,6 \%$ de $\mathrm{H}_{2} \mathrm{O}$ para incineração municipal

Disposição, tratamento das placas de fiação impressa

Emissões de $\mathrm{CO}_{2}$ equvalente

Quantidade final

$\begin{array}{ccc}\text { Quantidade } & \begin{array}{c}\text { Unidade de } \\ \text { medida }\end{array} & \text { Fluxo } \\ 0,074 & \mathrm{~kg} & \text { Input } \\ 0,0014 & \mathrm{~kg} & \text { Input } \\ 0,06 & \mathrm{~kg} & \text { Input } \\ 0,041 & \mathrm{~kg} & \text { Input } \\ 4,4 & \mathrm{~kg} & \text { Output } \\ 0,024 & \mathrm{pcs} & \text { Output }\end{array}$


Similar aos sistemas de gaseificação, cerca de $93 \%$ das emissões liberadas para o meio ambiente (ar, água e solo) do sistema FV são emissões atmosféricas. As principais contribuições em $\mathrm{kg}$ de $\mathrm{CO}_{\text {2equivalente do inteiro sistema são }}$ apresentadas na tabela 6.18 .

Tabela 6.18 - Síntese das principais emissões atmosféricas (orgânicas e inorgânicas) do sistema solar fotovoltaico.

\begin{tabular}{|c|c|}
\hline Emissões atmosféricas & Sistema Solar FV \\
\hline Emissões inorgânicas & $\mathrm{Kg} \mathrm{CO}_{2}$ Equivalente \\
\hline $\begin{array}{l}\mathrm{CO}_{2} \\
\mathrm{CO}_{2} \text { (biótico) } \\
\mathrm{CO}_{2} \text { (transformação do solo) } \\
\mathrm{NO}_{x} \\
\mathrm{Hexafluoreto} \mathrm{de} \mathrm{enxofre} \\
\text { Total }\end{array}$ & $\begin{array}{c}1,1 \mathrm{E} 006 \\
4,7 \text { E006 } \\
80 \\
1,5 \mathrm{E} 004 \\
3,7 \mathrm{E} 004 \\
1.2 \mathrm{E} 006\end{array}$ \\
\hline Emissões orgânicas & $\mathrm{Kg} \mathrm{CO}_{2}$ Equivalente \\
\hline $\begin{array}{l}\mathrm{NMVOC} \\
\mathrm{CH}_{4} \\
\mathrm{CH}_{4} \text { (biótico) }\end{array}$ & $\begin{array}{l}3,5 \text { E004 } \\
7,4 \text { E004 } \\
2,1 \text { E003 } \\
1.1 \text { E005 }\end{array}$ \\
\hline
\end{tabular}

Normalmente, durante a operação de plantas fotovoltaicas, não ocorre nenhuma emissão para o ar. Neste sentido, o total de emissões para o $\operatorname{ar}\left(\mathrm{kg}\right.$ de $\mathrm{CO}_{2}$ equivalente) estimado para o sistema FV foi de $195 \mathrm{~kg} / \mathrm{m}^{2}$ ou $30 \mathrm{~g} / \mathrm{kWh}^{15}$. As emissões devido à manutenção da planta aqui modelada foram consideradas no inventário do sistema.

Segundo Donnes \&Frischknetch (1998), consome-se em torno de 20 litros de água na lavagem dos painéis (remoção de poeira) por $\mathrm{m}^{2}$. O total de emissões para a água corresponde a $4 \%$ do total de emissões para o meio ambiente e a massa correspondente é de 4,8 E004 kg (48 t) de substâncias inorgânicas (principalmente, cloretos, sódio e sulfato).

\subsubsection{Análise do Balanço Energético}

\subsubsection{Demanda de Energia Acumulada de Energia e Tempo de Retorno de Investimento em Energia}

A CED da planta de energia fotovoltaica avaliada no presente trabalho foi calculada, conforme indicado na metodologia, e os valores alcançados no inteiro sistema são apresentados na figura 6.21. Embora os dados específicos para a

\footnotetext{
${ }^{15} \mathrm{O}$ valor de $30 \mathrm{~g}$ de $\mathrm{CO}_{2}$ equivalente $/ \mathrm{kWh}$, encontram-se dentro da escala de 30 a $45 \mathrm{~g}$ de $\mathrm{CO}_{2}$ equivalente $/ \mathrm{kWh}$, reportados por Alsema e Wild-Scholten, em 2004, para módulos de silício.
} 
demanda de energia primária da etapa de instalação $\left(E_{I}\right)$ da planta estejam disponíveis, os valores alcançados nesta fase são desprezíveis, quando comparados ao estágio de manufatura, isto é, $\mathrm{E}_{\mathrm{l}}=0^{16}$.

Dada à indisponibilidade de informações específicas da etapa de descomissionamento $\left(E_{D}\right)$ para a planta FV modelada neste estudo, esta demanda de energia também foi considerada nula $\left(E_{D}=0\right)$. Tal procedimento em relações a estas variáveis foi similar ao adotado por Keoleian \& Lewis (1997); Alsema (1998) e Koroneos et. al. (2006).

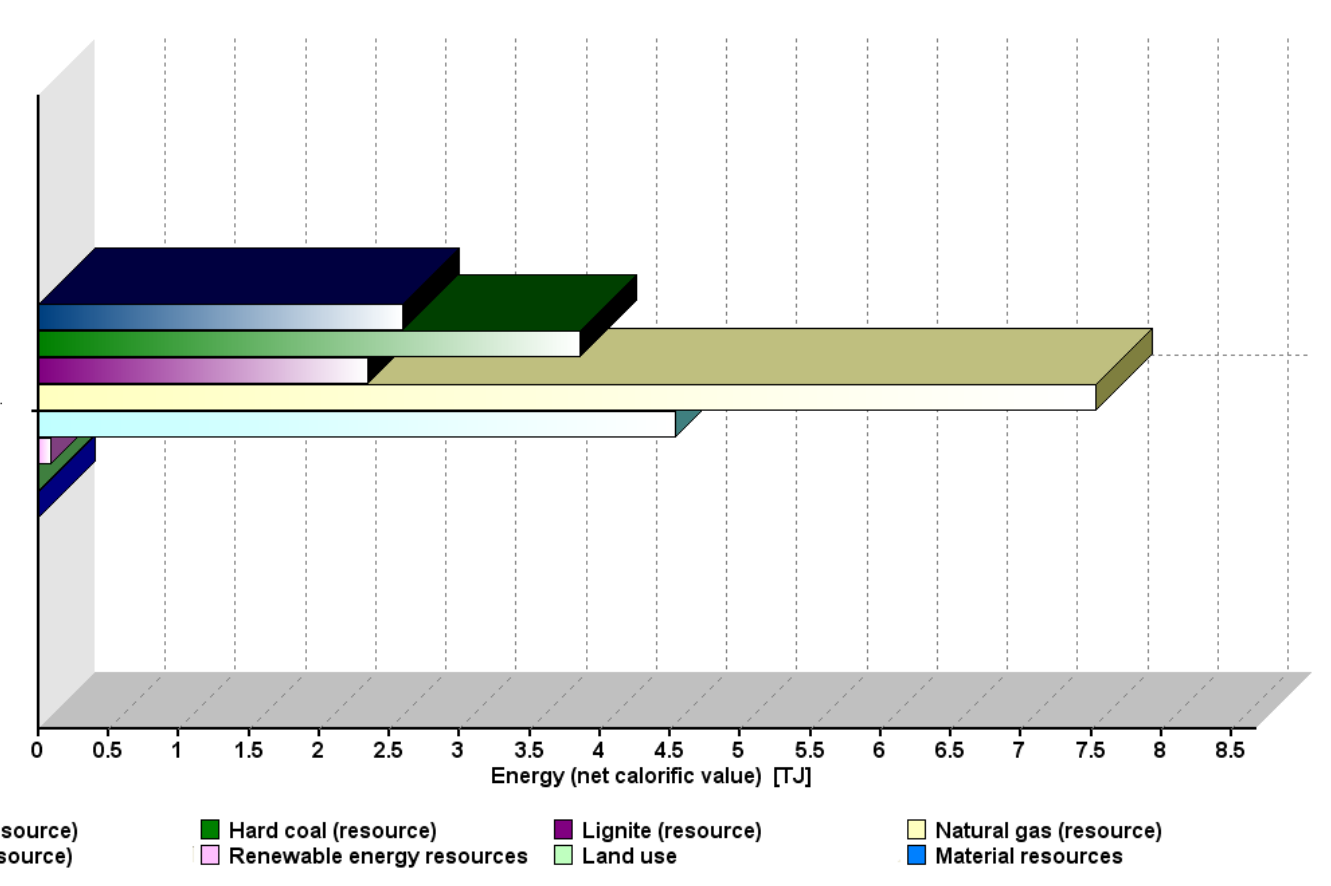

Figura 6.21 - Demanda Acumulada de Energia do sistema fotovoltaico (valor calorífico líquido em TJ)

Desta forma, a CED $\left(\mathrm{E}_{0}, \mathrm{~F}_{\mathrm{T}, 0}\right)$ do sistema FV corresponde a 23 TJ (3417 $\mathrm{MJ} / \mathrm{m}^{2}$ ), no qual os recursos não renováveis (urânio, gás natural, lignina, carvão e óleo cru) compreendem praticamente 100\% da CED. Notoriamente, dentre as diferentes contribuições, destaca-se o uso de gás natural e de urânio (eletricidade), com uma participação de 8,3 TJ e $5 \mathrm{TJ}$, respectivamente. Os valores absolutos e a contribuição relativa dos REN são apresentados na Tabela 6.19.

Em termos de processos produtivos, a maior contribuição na demanda de energia acumulada advém da produção do silício monocristalino (método CZ), o qual responde por 36\% do CED do sistema e cerca de 2.4 TJ do consumo de urânio. Em

\footnotetext{
${ }^{16}$.Tal como assumido para o estágio de operação da planta (Cf. capítulo 3)
} 
segundo lugar, encontra-se a produção mix de silício, cuja participação na CED é de $20,48 \%$ e de 3,4 TJ no uso de gás natural (Figura 6.22). De fato, tais processos são reconhecidos pelo o uso energético intensivo, dado a natureza de operação de cada processo (Alsema, 2000; Pacca et. al, 2007).

Tabela 6.19 - Valores absolutos e contribuição relativa dos recursos não renováveis na Demanda Acumulada de Energia do sistema FV:

\begin{tabular}{|c|c|c|}
\hline Sistema Solar & Fotovoltaico ( $1 \mathrm{MW}$ ) & \\
\hline Fluxo de entrada & $\begin{array}{l}\text { Contribuição } \\
\text { relativa (\%) }\end{array}$ & $\begin{array}{c}\text { Valores } \\
\text { absolutos } \\
\text { (TJ) }\end{array}$ \\
\hline $\begin{array}{l}\text { Recursos de energia não } \\
\text { renovável (total) }\end{array}$ & 99,6 & 23 \\
\hline Óleo Cru & 12 & 2,9 \\
\hline Carvão mineral & 18 & 4,3 \\
\hline Lignina & 11 & 2,6 \\
\hline Gás natural & 36 & 8,3 \\
\hline Urânio & 22 & 5 \\
\hline $\begin{array}{l}\text { Recursos de energia } \\
\text { renovável }\end{array}$ & 0,39 & 0,0091 \\
\hline $\begin{array}{l}\text { Recursos de energia em } \\
\text { materiais }\end{array}$ & 0,00093 & 0,00022 \\
\hline $\begin{array}{l}\text { Total de recursos de } \\
\text { energia }\end{array}$ & 100 & 23 \\
\hline
\end{tabular}

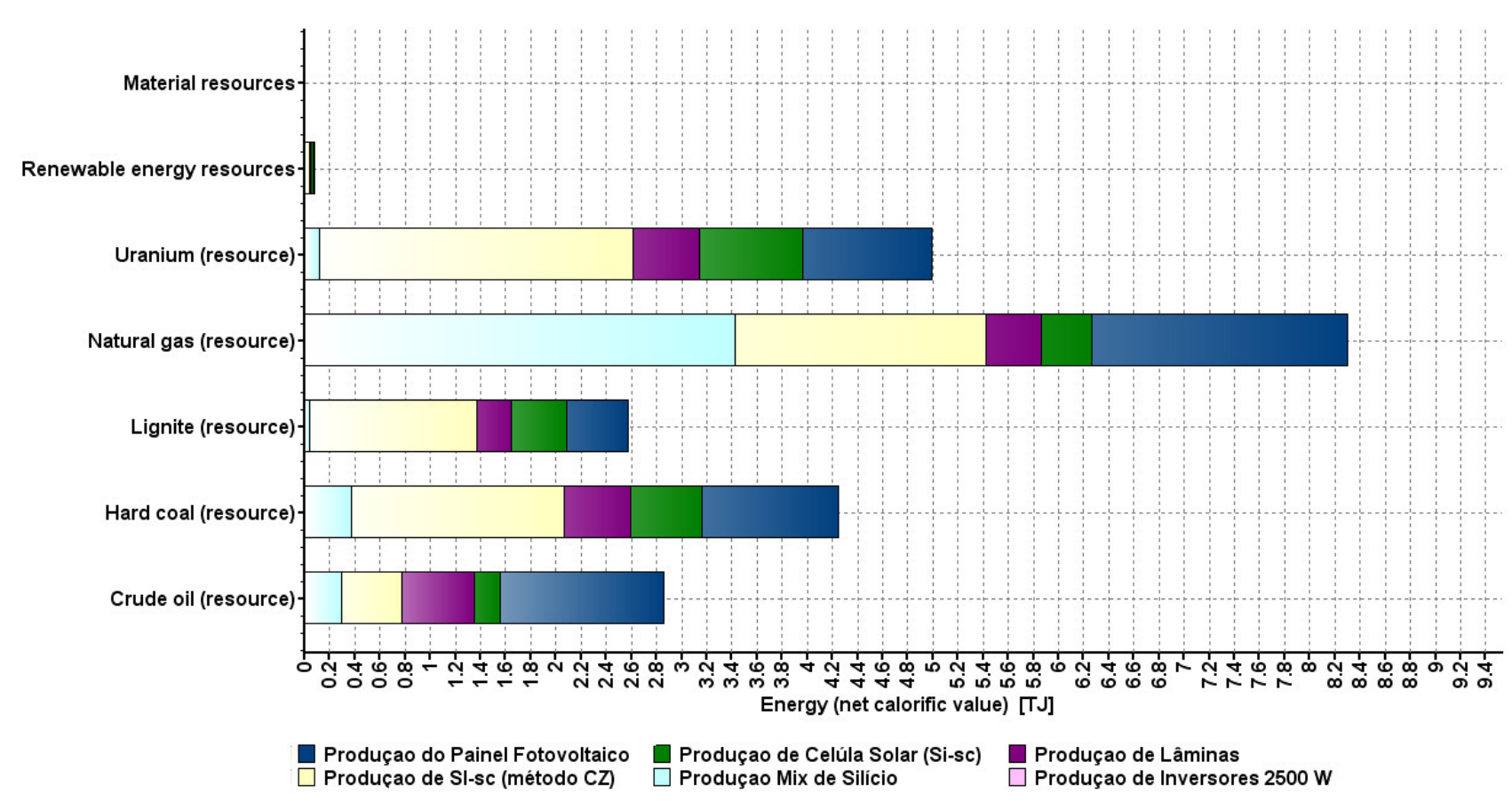

Figura 6.22 - Demanda Acumulada de Energia de cada processo produtivo do sistema FV (valor calorífico liquido em TJ).

O terceiro maior contribuinte na CED do sistema FV é a produção dos painéis solares. Esta etapa apresenta um montante de 4,0 TJ e é responsável por cerca de $17 \%$ do consumo de energia total do sistema FV. Particularmente, a moldura de 
alumínio utilizada nos painéis aumenta significativamente a CED e, conforme Keoleian \& Lewis (1997), responde por uma fração considerável dos requerimentos de energia no processo de produção de painéis solares. Destaca-se que a contribuição dos inversores na CED é praticamente nula em relação aos demais estágios produtivos.

No que tange à produção anual líquida do sistema $\mathrm{FV}$, esta foi estimada em 1.440.758,400 kWh/kWp, o que corresponde a 5,1 TJ. O tempo de retorno de investimento de energia (EPBT) é de 4,5 anos. Este valor é coerente com o cenário tecnológico atual (FUKUROZAKI \& PASCHOAL, 2010) e, especificamente, em relação à mesma tecnologia (Si-sc), próximo às últimas estimativas reportadas na literatura por Alsema \& Wild-Schoten (2008) e Jungbluth \& Frischkneecht (2008). No que tange ao balanço energético líquido, o sistema FV produz cerca de 6 vezes a mais energia do que demanda no seu inteiro ciclo de vida.

\subsubsection{Avaliação de Impacto Ambiental}

O sistema de energia fotovoltaico foi avaliado conforme a metodologia do Eco-indicador 99 e os resultados obtidos são apresentados na figura 6.23.

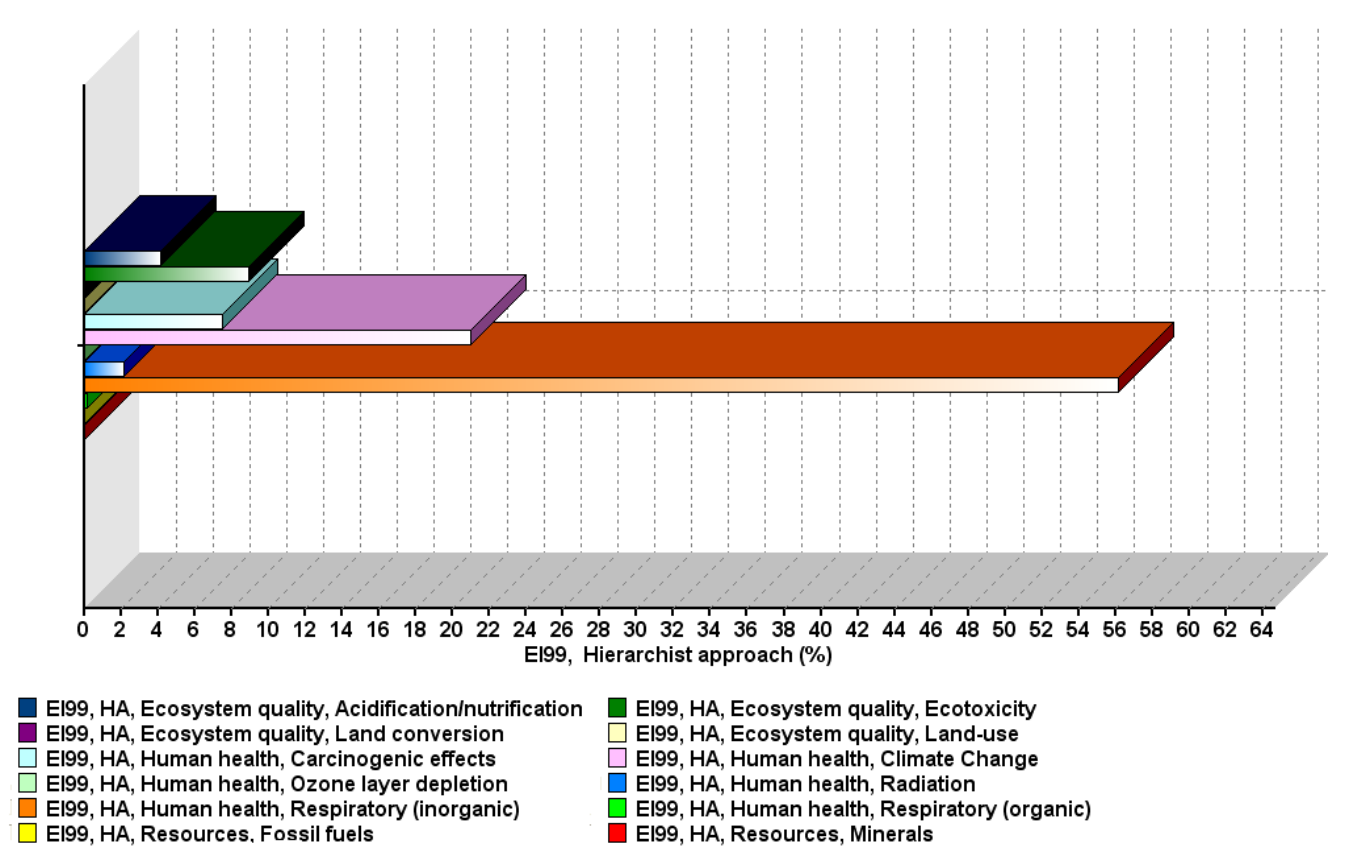

Figura 6.23 - Contribuição relativa dos danos a SH, QE e RMCF do sistema FV (percentual de participação)

Os danos à saúde humana caracteriza a maior contribuição de carga ambiental do sistema FV. Os dois principais parâmetros que contribuíram para os 
danos nesta categoria foram: os Efeitos Respiratórios - causados por substâncias inorgânicas (56\%) e as Mudanças Climáticas (21\%). No que tange aos danos à qualidade do ecossistema, o parâmetro Ecotoxicidade responde pela maior participação (8,9\%). A tabela 6.20 apresenta a contribuição relativa de cada parâmetro e o valor agregado por categoria de dano.

Tabela 6.20 - Contribuição relativa de cada parâmetro e o valor agregado por categoria de dano do sistema FV:

\begin{tabular}{lcc}
\multicolumn{1}{c}{ Eco-indicador 99 } & Sistema FV & Valor agregado \\
QE - Acidificação/Nitrificação & 4,10 & \\
QE - Ecotoxicidade & 8,90 & 13 \\
QE - Conversão do solo & 0,00 & \\
QE - Uso do Solo & 0,00 & \\
SH - Efeitos carcinogênicos & 7,50 & \\
SH - Mudanças climáticas & 21,00 & $\mathbf{8 7}$ \\
SH - Depleção da camada de ozônio & 0,024 & \\
SH - Radiação ionizante & 2,10 & \\
SH - Efeitos respiratórios (inorgânicos) & 56,00 & \\
SH- Efeitos respiratórios (orgânicos) & 0,12 & $\mathbf{0 . 0 0}$ \\
RMCF - Combustiveis fósseis & 0,00 & $\mathbf{1 0 0}$ \\
RMCF - Recursos minerais $\quad$ Total & 0,00 & \\
\end{tabular}

Designadamente em relação aos processos produtivos do sistema $\mathrm{FV}$, a produção de silício monocristalino e a do painel fotovoltaico são os estágios produtivos que mais contribuem tanto para os danos relacionados aos efeitos respiratórios (substâncias inorgânicas), quanto às mudanças climáticas (Figura 6.24).

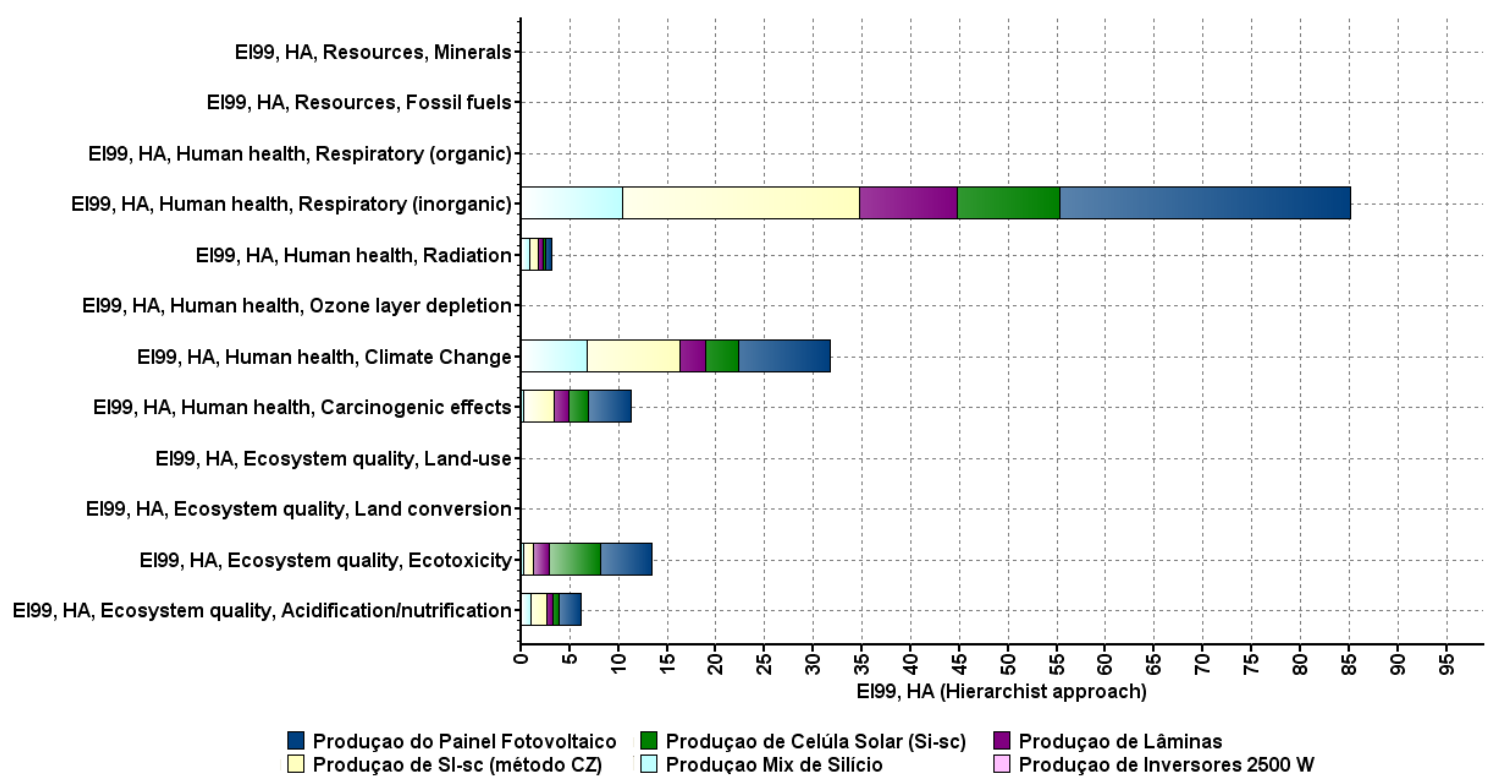

Figura 6.24 - Contribuição relativa de cada processo produtivo do sistema FV de danos a SH, QE e RMCF (percentual de participação). 
Notadamente, todos os estágios produtivos do sistema fotovoltaico apresentam um percentual de participação dos danos relacionados à saúde humana maior que $50 \%$ em relação às demais categoriais de danos (QE e RMCF), conforme pode ser observado na figura 6.25 .

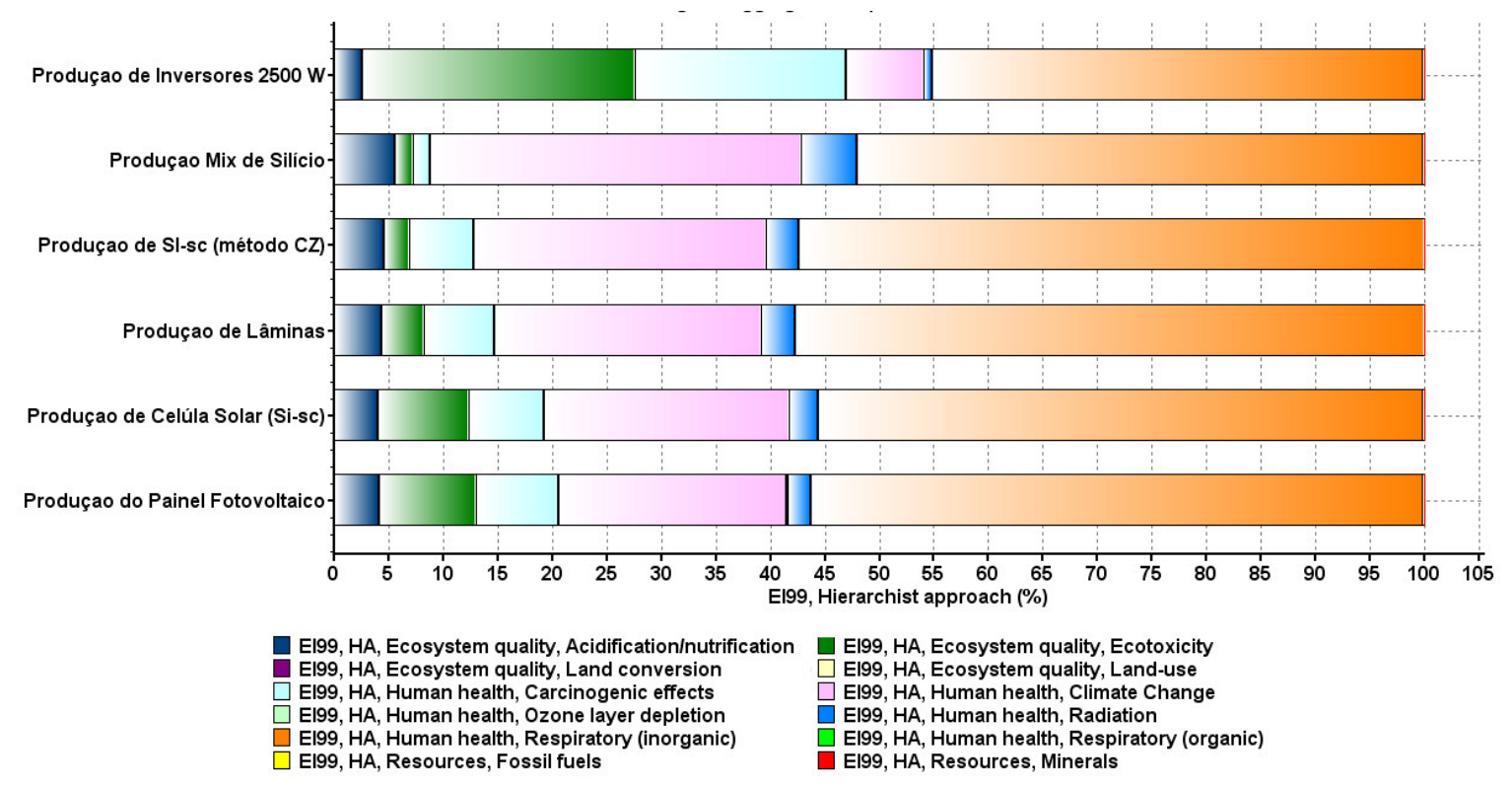

Figura 6.25 - Contribuição relativa dos danos a SH, QE e RMCF por processo produtivo do sistema FV (percentual de participação normalizados para $100 \%$ ).

Destaca-se que, na produção de inversores ocorre uma significativa participação do parâmetro ecotoxicidade (cerca de 20\%) e efeitos carcinogênicos (20\%), contrário ao que ocorrem nos demais estágios. Todavia, em termos de valor agregado, estas contribuições do processo não são significativas no cômputo total de danos oriundos da etapa de manufatura do sistema.

Em síntese, os principais impactos ambientais (danos a $\mathrm{SH}$ e a QE) do sistema FV baseado em Si-sc são decorrentes, principalmente, do uso de recursos energeticos não renováveis e consequentes emissões atmosféricas (Cf. JUNGBLUTH et.al, 2004). Isto é, a cadeia de manufatura do sistema FV apresenta uma alta demanda de energia e, conforme Dones \& Frischknecht (1998), esta demanda determina a maior parte da carga ambiental de sistemas FV, em oposição à fase de produção de eletricidade dos mesmos.

Não obstante, é importante ressaltar que as características da matriz de fornecimento de energia na Europa (mix de eletricidade), onde os componentes da 
planta fotovoltaica são produzidos colaboram para o perfil de danos encontrados no sistema.

Comparado aos sistemas de gaseificação (LFX e LFL), o sistema FV apresenta melhor desempenho ambiental na categoria de danos á saúde humana, enquanto os dois sistemas de gaseificação apresentam uma carga menor de impactos em relação à qualidade do ecossistema. Os três sistemas apresentaram o mesmo perfil em relação aos danos pertinentes aos recursos minerais e combustíveis fósseis (Figura 6.26 e Figura 6.27).

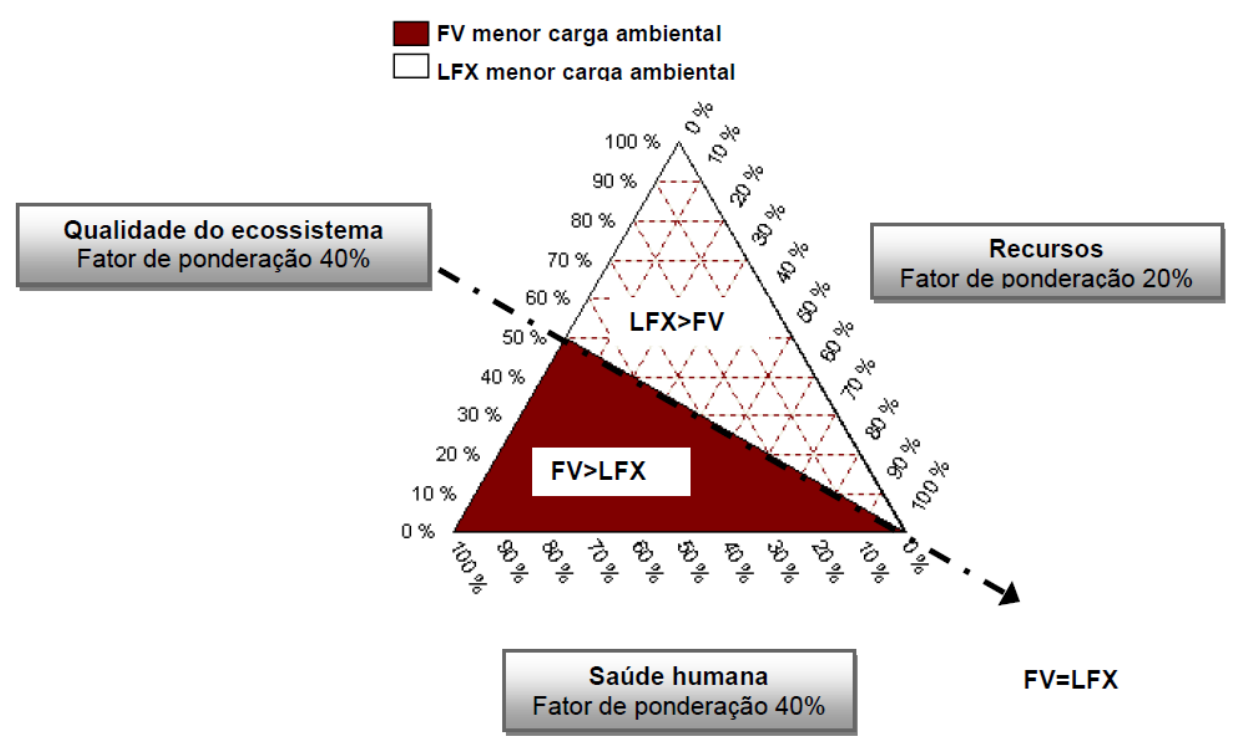

Figura 6.26 - Comparação do desempenho ambiental entre o sistema de gaseificação LFX e o sistema FV

Em termos de balanço de energia líquida, todos os sistemas apresentam um coeficiente positivo, isto é, produzem mais energia no seu tempo de vida útil do que consomem no seu inteiro ciclo de vida. Destaca-se que as plantas de gaseificação apresentem um fator de produção (28) 5 vezes maior do que a planta fotovoltaica (6).

Em relação à produção de hidrogênio, diversos sistemas de energia solar fotovoltaica têm sido integrados a eletrolisadores para produzir $\mathrm{H}_{2}$ puro (Cf. capítulo 2). Conforme Kroposki et. al (2006), idealmente, $39 \mathrm{kWh}$ e 8,9 litros de água são necessários para produzir $1 \mathrm{~kg}$ de hidrogênio a $25{ }^{\circ} \mathrm{C}$ e $1 \mathrm{~atm}$. Tipicamente, as eficiências dos eletrolisadores comerciais variam de $56 \%$ a $73 \%$ e isto corresponde 
a uma de demanda de energia elétrica de 70,1 kWh a 53,4 kWh por $\mathrm{kg}$ de $\mathrm{H}_{2}$ (NREL, 2004).

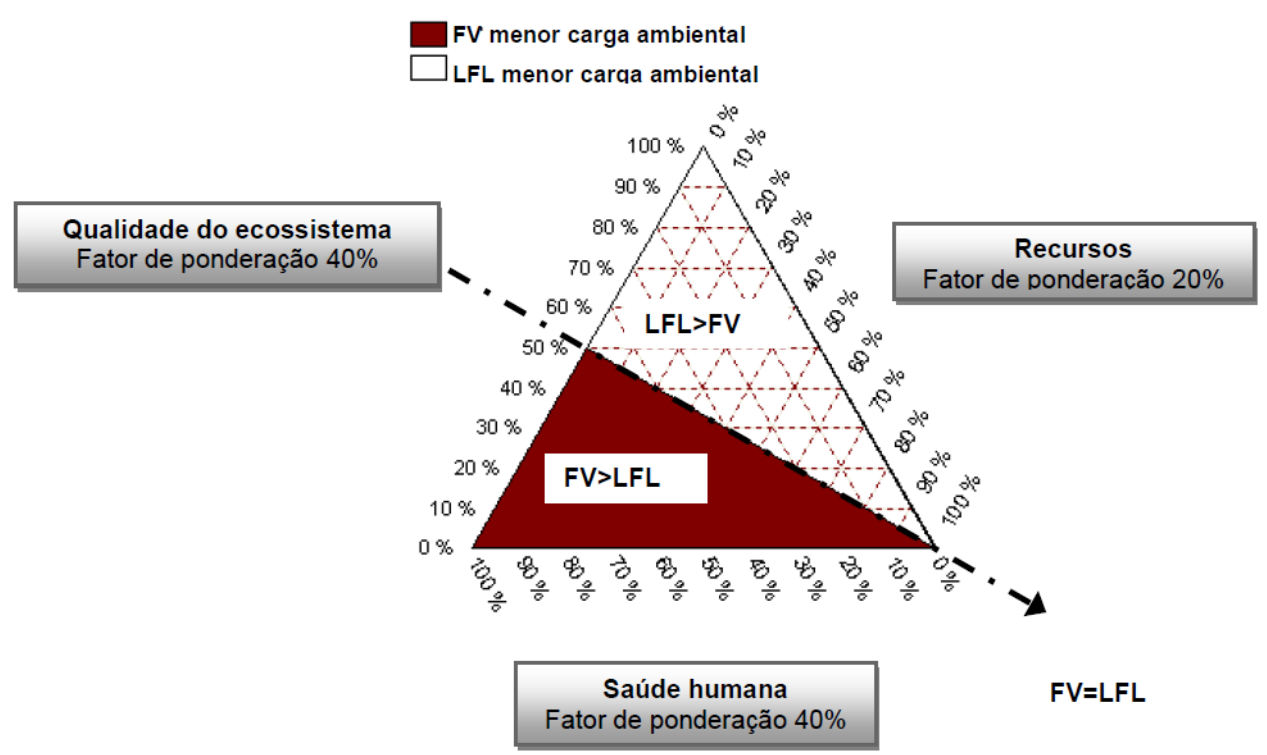

Figura 6.27 - Comparação do desempenho ambiental entre o sistema de gaseificação LFL e o sistema FV.

Neste sentido, estima-se que o sistema fotovoltaico (modelado no presente estudo) integrado a um eletrolisador, seja capaz de produzir diariamente $88,5 \mathrm{~kg}$ de hidrogênio puro, considerando a média irradiação de $5,45 \mathrm{kWh} / \mathrm{m}^{2} /$ dia e a potência instalada de $1 \mathrm{MWp}$, bem como a média de consumo de energia de $61,75 \mathrm{kWh} / \mathrm{kg}$ $\mathrm{H}_{2}$.

Diante deste quadro, ressalta-se que:

I) O sistema FV, comparado aos sistemas de gaseificação, apresenta uma demanda acumulada de energia primária (23 TJ) em torno de $50 \%$ menor, comparado aos sistemas de gaseificação (50, 01 TJ no LFX e 47,11 TJ no LFL), porém o tempo de retorno de investimento em energia ( 4,5 anos) é mais que o dobro em relação aos valores obtidos para os sistemas de gaseificação (de 1,65 a 1,77 anos).

II) Em relação aos impactos ambientais, o sistema FV apresentou uma menor carga (em torno de $9 \%$ a menos) na categoria de danos à saúde (87\%) comparada aos valores encontrados nos sistemas de gaseificação (de 94 a 95\%). É interessante observar que, especificamente em relação aos parâmetros desta categoria, os sistemas de gaseificação apresentam maior participação em relação às 
mudanças climáticas, enquanto no sistema FV a maior contribuição está relacionada aos efeitos respiratórios (substâncias inorgânicas).

III) Na categoria de danos à qualidade do ecossistema, tanto nos parâmetros acidificação/eutrofização, quanto ecotoxicidade, os valores do sistema FV foram relativamente maiores do que os encontrados nos sistemas de conversão da biomassa, aqui estudados. Em termos de valor agregado, o sistema FV apresenta uma diferença de 37\% a mais de contribuição em relação ao LFX e, cerca de $44 \%$ a mais comparado ao LFL.

Ao consideramos os custos encontrados na literatura sobre os sistemas de gaseificação de 1,44 a 2,83\$/kg e os sistemas híbridos de energia solar fotovoltaica de 0,98 a $6,02 \$ / \mathrm{kg}$ (cf. capítulo 2), a produção de $\mathrm{H}_{2}$ via gaseificação da biomassa pode representar uma opção mais adequada em um dado momento e local do que a energia solar e, vice versa. Isto é, a definição final sobre qual sistema utilizar também dependerá das variáveis envolvidas na análise de custos.

Destarte, ratifica-se que o intuito da avaliação do ciclo de vida realizada no presente trabalho não é o de apontar o potencial de cada uma das rotas alternativas de produção de hidrogênio, considerando o uso de energia, consumo de recursos e materiais, emissões esperadas com suas possíveis aplicações e consequências. 
Este capítulo apresenta as conclusões do estudo e constituem a quarta e última fase do processo da Avaliação do Ciclo de Vida, denominada Interpretação. Tal como mencionado na metodologia, esta etapa considerou a análise da identificação das questões majoritárias em função do objetivo e escopo estabelecidos na ACV dos sistemas de gaseificação e de energia solar fotovoltaica.

\section{Interpretação}

O potencial de contribuição da biomassa e da energia solar no suprimento energético mundial e, principalmente no Brasil, onde tais recursos renováveis encontram-se em abundância, são enormes e promissoras. Não obstante, o uso de tecnologias de gaseificação e conversão fotovoltaica como rotas de produção de hidrogênio apresentam particularidades favoráveis para o desenvolvimento de Sistemas de Energia Sustentáveis.

Por esta razão, é importante avaliar as consequências ambientais do ciclo de vida das mesmas, enquanto a tomada de decisões sobre os aspectos técnicos, econômicos e ambientais ainda estão sendo definidas. Neste caso, a Avaliação do Ciclo de Vida é uma ferramenta fundamental para avaliar e conduzir o desenvolvimento de tecnologias energéticas.

Ao analisarmos o ciclo de vida dos sistemas de gaseificação e de energia solar fotovoltaica em relação às suas emissões, o consumo de recursos e demanda de energia, foi possível determinar os respectivos desempenhos energético e ambiental, de tal forma que os objetivos propostos no estudo foram atendidos.

Em relação à metodologia, ressalta-se que os resultados dos danos analisados dependem das fronteiras do sistema estabelecidas no estudo (escopo), bem como dos fatores de normalização e ponderação utilizados na avaliação de impactos do ciclo de vida, uma vez que estão baseados nas condições européias.

Destaca-se ainda, dois aspectos importantes do método de avaliação impactos aplicado no estudo: i) um único elemento inventariado (substância, processo ou atividade) é comumente associado a múltiplos impactos (danos) e ii) nem todos estes elementos dentro e/ou em distinta categoria de impactos resultam em quantidades iguais de danos ao meio ambiente. Isto por sua vez, também reforça os resultados encontrados na categoria de danos recursos minerais e 
combustíveis fósseis e enfatiza a necessidade de utilizar outros parâmetros de análise energética, para fornecer uma visão complementar em relação à obtida no Eco-indicador 99.

De forma análoga às demais fases do sistema FV em que as contribuições são desprezíveis, as etapas de manufatura, instalação e descomissionamento, são as que menos influenciam o desempenho energético e ambiental dos sistemas de gaseificação.

Do ponto de vista do potencial de produção de hidrogênio é importante destacar que, enquanto os sistemas de gaseificação, modelados no estudo, produzam um combustível (syngas) que pode ser utilizado diretamente em células a combustível de alta temperatura, o sistema fotovoltaico integrado ao eletrolisador pode produzir um gás ultrapuro, ideal para aplicações em células de baixa temperatura.

Diante dos parâmetros analisados e os resultados obtidos no presente estudo, observa-se que, se por um lado os sistemas de gaseificação proporcionam um melhor desempenho energético, por outro, o sistema de energia solar fotovoltaica é o mais ambientalmente favorável para a produção de energia. De fato, os sistemas estudados apresentam mais características de complementaridade do que competição.

Neste contexto, a tomada de decisão sobre qual dos sistemas de conversão de energia aqui considerados é o mais favorável em um dado local, reforça a demanda por uma análise dos fatores econômicos e sociais pertinentes a cada país ou região, considerando também o inteiro ciclo de vida dos sistemas. O resultado da avaliação econômica com esta abordagem agregado às conclusões obtidas na avaliação do ciclo de vida propiciarão, indubitavelmente, informações que permitam efetivamente o desenvolvimento e aplicação de Sistemas de Energia Sustentável. 


\section{Estudos Futuros}

Em virtude das considerações apresentadas no decorrer e final do presente estudo torna-se necessário frisar a continuidade de estudos futuros. Para complementar este trabalho, recomenda-se:

1) A avaliação das etapas de cultivo da biomassa de culturas energéticas e das fontes de recursos renováveis de origem residual no Brasil, bem como das etapas relacionadas à mineração da sílica e produção de silício metalúrgico (no qual o Brasil é um importante fornecedor), com intuito de identificar a influência das mesmas em termos ambientais e econômicos no ciclo de vida do sistema.

2) Estudos do Ciclo de Vida de Custos associados ao consumo de recursos, materiais, energia, tratamento ou disposição de emissões para o meio ambiente e/ou outra avaliação econômica (como, por exemplo, a propiciada pela ExternE) que considere os efeitos das externalidades geradas ao longo da cadeia produtiva dos sistemas de conversão.

3) Análises de sensibilidade com o intuito de identificar como as mudanças nos dados e nas escolhas metodológicas podem afetar os resultados da avaliação de impactos ambientais do ciclo de vida, nos diferentes estágios do sistema gasificação da biomassa e da planta de energia solar fotovoltaica.

Por fim, faz-se necessário uma avaliação ambiental dos processos posteriores pertinentes à produção de hidrogênio (reforma, purificação e eletrólise), preferencialmente, já integrados aos sistemas de energia renovável aqui avaliados. 
ALLY, J. \& PRYOR, T. Life Cycle Assessment of Diesel, Natural Gas and Hydrogen Fuel Bus Transportation Systems. Journal of Power Sources, 170, 2007. pp. 401411.

ALSEMA, E. A. Energy Requirements of Thin-film Solar Cell Modules: a review. Renewable Sustainable Energy Rev. 2,1998 . pp. 387-415.

ALSEMA, E. A. Energy Requirements and $\mathrm{CO}_{2}$ Mitigation Potential of PV Systems. In: Photovoltaics and Environment 1998, BNL/NREL, Keystone, CO, 1999.

ALSEMA, E. Energy Payback Time and $\mathrm{CO}_{2}$ Emissions of PV Systems. Prog. Photovol.: Res. Appl. 8, 2000. pp.17-25.

ALSEMA, E. A.; DE WILD-SCHOLTEN, M. Environmental Impact of Crystalline Silicon Photovoltaic Module Production. Presented at Materials Research Society Symposium, Boston, Nov., 2005.

ALSEMA E. A. AND WILD-SCHOTEN, M.J. Reduction of Environmental Impacts in Crystalline Silicon Photovoltaic Technology: An Analysis of Driving Forces and Opportunities. Materials Research Society. Symposium Proceedings Volume 1041, 2008. pp. 3-12.

ANEEL - AGÊNCIA NACIONAL DE ENERGIA ELÉTRICA. Atlas de Energia Elétrica no Brasil. 2. Ed. Brasília: ANEEL( 2005). 243 p.

ABNT - ASSOCIAÇÃO BRASILEIRA DE NORMAS TÉCNICAS. NBR ISO 14.044 Gestão ambiental - Avaliação do ciclo de vida: Requisitos e Orientações. Rio de Janeiro: ABNT, 2009.

BABIR, F. Transition to Renewable Energy Systems with Hydrogen as an Energy Carrier. Energy, 34, 2009. pp. 308-312.

BAIN, R. O., R. \& CRAIG, K. Gaseificação para a Geração de Calor e Eletricidade e a Produção de Metanol e Hidrogênio. In: Uso da biomassa para a produção na indústria brasileira. ROSILLO-CALLE, F., BAJAY, S. V. \& ROTHMAN, H. (Org.); 
tradutores ROCHA, J. D. \& ROCHA, M. P. G. D. - Campinas, SP: Editora da UNICAMP, 2005. 447p.

BALLAT, M. Potential Importance of Hydrogen as a Future Solution to Environmental and Transportation Problems. International Journal of Hydrogen Production 33, 2008. pp.4013-4029.

BARTELS, J et.al. An Economic Survey of Hydrogen Production from Conventional an Alternative Sources. International Journal of Hydrogen Production 35, 2010. pp.8371-8384.

BAUEN, A. et. al. Fuel Cells for Distributed Generation in Developing Countries - an analysis. International Association for Hydrogen Energy. Elsevier Science Ltda. 2003. pp. $695-701$.

BAUMANN, H \&TILLMAN, A.M. \&. The Hitch Hiker's Guide to LCA. An Orientation in Life Cycle Assessment Methodology and Application, Studentlitteratur, Lund, Sweden (2004).

BAIN, R. OVEREND, R. \& CRAIG, K. Gaseificação para a geração de calor e eletricidade e a produção de metanol e hidrogênio. In: Uso da biomassa para a produção na indústria brasileira. ROSILLO-CALLE, F., BAJAY, S. V. \& ROTHMAN, H. (ORG); tradutores ROCHA, J. D. \& ROCHA, M. P. G. D. - Campinas, SP: Editora da UNICAMP, 2005, 447P.

BRidghateR, A. V. AND G. V. C. PEACOCKE . Fast Pyrolysis Processes for Biomass. Renewable and Sustainable Energy Reviews 4, 2000. pp.1-73.

BROWN, R. C. Biomass Refineries based on Hybrid Thermochemical/Biological Processing- an Overview. Biorefineries, Biobased Industrial Processes and Products, Kamm, B., Gruber, P. R., Kamm, M. (eds). Wiley - VCH Verlag, Weinhein, Germany, 2005.

CALDEIRA-PIRES - PIRES, A. et.al. (org.). Avaliação do Ciclo de Vida: a ISO 14040 na América Latina. - Brasília: Abipit, 2005. 330p. 
CENTRO DE GESTÃO E ESTUDOS ESTRATÉGICOS - CGEE. Estado da Arte e Tendências das Tecnologias de Energia. Secretaria técnica do Fundo Setorial de Energia, 2003. 75p.

CENTRO DE REFERENCIA EM BIOMASSA - CENBIO. Atualização do Panorama do Potencial de Biomassa no Brasil. Disponível em http://www.cenbio.org.br/pt/dadosbiomassa.html. Acesso em setembro de 2007.

CHAPMAN, P.F. \& ROBERTS, F. Metal Resources and Energy. Butterworths Monographs in Materials. 1983.

COELHO, S. T. Panorama do Potencial de Biomassa no Brasil. Brasília: ANEEL, 2002. $75 p$.

COHEN, C. Padrões de Consumo e Energia: Efeitos sobre o Meio Ambiente e o Desenvolvimento. In: Economia do meio ambiente: teoria e prática. MAY, P.H; LUSTOSA, M. C.; da VINHA, V. ( org). Rio de Janeiro: Elsevier, 2003. pp. 245-269.

DONES R, FRISCHKNECHT R. Life Cycle Assessment of Photovoltaic Studies: Results of Swiss Studies on Energy Chains. Progress in Photovoltaics: Research and Applications, 6, 1998. pp.117-125.

DAUIRIAT, A. \& GNANSOUMOU, E. Synthetic biofuels. Ecoinvent report $n^{0} 17$. Swiss Centre for Life Cycle Inventories, Dubendorf, CH, 2007. pp.505 - 557.

FAAIJ et. al. Novas Tecnologias para os Vetores Modernos de Energia de Biomassa. In: Uso da Biomassa para a Produção na Indústria Brasileira. ROSILLOCALLE, F., BAJAY, S. V. \& ROTHMAN, H. (ORG); tradutores ROCHA, J. D. \& ROCHA, M. P. G. D. - Campinas, SP: Editora da UNICAMP, 2005, 447p.

FEDERAÇÃO DA INDÚSTRIAS DO ESTADO DE SÃO PAULO/ ONFEDERACAO DAS INDÚSTRIAS DO ESTADO DE SÃO PAULO - FIESP /CIESP. Ampliação da Oferta de Energia através da Biomassa. São Paulo: FIESP/CIESP, 2001. 90p.

FOOD AND AGRICULTURAL ORGANIZATION OF THE UNITED NATIONS Wood Gas as Engine Fuel. Forestry Paper 72. Roma, Italy,1986. 
FTHENAKIS, V.M.; ALSEMA, E.A. Wild-Schoten, M.J.. Life Cycle Assessment of Photovoltaics: perceptions, needs and challenges. 31st IEE Photovoltaics Specialists Conference, Jan 3-7, 2005.

FTHENAKIS,V.M. AND ALSEMA, E. Photovoltaics Energy Payback Time, Greenhouse Gas Emissions and External Costs: 2004-early 2005 Status. Prog. Photovol.: Res. Appl. (14), 2006. pp. 275-280.

FTHENAKIS, V. M.; KIM, H.C. AND ALSEMA E. Emissions from photovoltaic life cycles. Environmental Science and Technology 42 (6), 2008. pp. 2168-2174.

FTHENAKIS, V. M; ZWEIBEL, R. AND MASON, J. The technical, geographical, and economic feasibility for solar energy to supply the energy needs of the United States. Energy Policy 37 (2), 2009. pp. 387-399.

FUKUROZAKI, S.H. Análise Ambiental da Célula a Combustível de Membrana Trocadora de Prótons sob o enfoque da Avaliação do Ciclo de Vida. Dissertação (Mestrado em Ciência). Universidade de São Paulo. Instituto de Pesquisas Energéticas e Nucleares - IPEN, 2006. 150p.

FUKUROZAKI, S.H, PASCHOAL, J.O.A. \& COIMBRA, C.F. LCA, EPBT and Cost of PV Technology; an Overview. Renewable Energy 2010 International Congress, Okohama, Japan, 2010.

FUKUROZAKI, S.H \& PASCHOAL, J.O.A. Avaliação do Ciclo de Vida de Tecnologias Fotovoltaicas: Panorama Atual do Tempo de Retorno de Investimento em Energia e Custos Associados. III Congresso Brasileiro de Energia Solar - Belém, 21 a 24 de setembro de 2010.

GRANOVSKII, M.; DINCER, I; ROSEN, M.A. Life Cycle Assessment of Hydrogen Fuel and Gasoline Vehicles. International Journal of Hydrogen Energy, 31, 2006. pp.337-352.

GRANOVSKII,M.;DINCER,I.;ROSEN,M.A. Exergetic Life Cycle Assessment of Hydrogen Production from Renewable. Journal of Power Sources, 167, 2007. pp.461-471. 
GRAY, D. \& TOMLINSON, G. Hydrogen from Coal. MTR 2002-31. Mitreck; 2002.

GRIMONI, J. A. B, GALVÃO, L.C.R. \& UDAETA, M. E. M. (org). Iniciação a Conceitos de Sistemas Energéticos para o Desenvolvimento Limpo.- São Paulo: Editora da Universidade de São Paulo, 2004. 306p.

GOEDKOPP, M. \& SPRIENSMA, R. The Eco-indicator 99: a Damage Oriented Method for Life Cycle Assessment. Methodology report. Pré-consultants B.V. 2001, $132 \mathrm{p}$.

HALL C. A. S., C. J. CLEVELAND, \& R. K. KAUFMANN. Energy and Resource Quality: The Ecology of the Economic Process. Wiley Interscience, New York, 1986.

HALL, D.O; HOUSE,JO.L; \& SCRASE, I. Visão Geral de Energia e Biomassa. In: Uso da biomassa para a produção na indústria brasileira. ROSILLO-CALLE, F., BAJAY, S. V. \& ROTHMAN, H. (Org.); tradutores ROCHA, J. D. \& ROCHA, M. P. G. D. - Campinas, SP: Editora da UNICAMP, 2005, 447p.

HAMELINCK,C.N \&FAAIJ, A. P. Future prospects for production of methanol and hydrogen from biomass. University of Ultrech, Netherlands,2001.

HANSEN, J. L. Fluidized bed combustion of biomass: an overview. Proc. Biomass Combustion. Washington, D.C. Reno: U. S. Department of Energy, 1992.

HAUSSINGER, P. LOHMULLER, R. \& WATSON, A. M. Hydrogen. Ullmanns Encyclopedia of Industrial. Wiley-VCH Verlag GmbH \& Co.KGaA, 2000.

HAUSCHILD, M \& WENZEL. Environmental Assessment of Products, part 2: Scientific Background. Chapman and Hall: Cambridge, 1998.HEIJUNGS Environmental Life Cycle of Products: Backgrounds. Report. Nr 9266. CML, Leiden.

HENDRICKSON, C. T; LAVE, L.B.;MATTHEWS, H.S. Environmental Life Cycle Assessment of Goods and services: an Input-Output Approach. Washington, DC: RFF Press Book, 2006. 
HEIJUNGS, R.J.B, HUPPES, R.M,.LANKREIJER, H.A. UDO DE HAES, A. et. al. Environmental Life Cycle Assessment of Products: Backgrounds. Report, CML, Leiden.

HERZOG, A. \& TATSUTANI, M. A Hydrogen Future? An Economic and Environmental Assessment of Hydrogen Production Pathways. Natural Resources Defense Council, 2005. 23p.

HOFFMANN, W. PV solar electricity industry: Market growth and perspective. Solar Energy Materials and Solar Cells 90(18-19), 2006. pp. 3285-3311.

HOLDREN, J.P. \& SMITH, K. R. Energy, the Environment and Health. In World energy assessment; energy and the challenge of sustainability. United Nations Development Programme, United Nations Department of Economic and Social Affairs, Word Energy Council, 2000. pp. 65-104.

HOLLADAY, J.D; HU, J.; KING D.L.; WAN Y. An Overview of Hydrogen Production Technologies. Catalysis Today 139. (2009).pp 244-260.

IEA - PVSP. International Energy Agency/ Photovoltaic Power Systems Programme. Trends in PV Application in Selected IEA CounEPBTs between 1992 and 2000, report IEA-PVPS 1-10: 2001.

IEA - PVPS. International Energy Agency/ Photovoltaic Power Systems Programme. Trends in Photovoltaic Applications: survey report of selected IEA countries between 1992 and 2008. Report IEA-PVPS T1-18: 2009.

IFIAS - International Federation of Institutes for Advanced Studies.Report on the Workshop on Energy Analysis and Economics (in Lindigoe, Sweden, June 1975). Resources and Energy (1),1978. pp. 151-204.

IPCC - INTERNATIONAL PANEL OF CLIMATE CHANGE. Climate Change 2001: Working Group II. Impacts, adaptation and vulnerability. Disponível em: http://www.grida.no/climate ipcc/wg2/005.html. Acesso em setembro/2006. 
ISO - INTERNATIONAL ORGANIZATION FOR STANDARDIZATION. Environmental management - Life Cycle Assessment- ISO 14.040. Genebra: ISO, 1997.

JOCHEM, E. Energy End-Use Efficiency. In World energy assessment; energy and the challenge of sustainability. United Nations Development Programme, United Nations Department of Economic and Social Affairs, Word Energy Council, 2000. pp. 173-211.

JOSHI, A. S.; DINCER, I. \& REDDY, B. V. Exergetic Assessment of Solar Hydrogen Production Methods. International Journal of Hydrogen Energy 35 , 2010. pp. $4901-4908$.

JUNGBLUTH, N. Life Cycle Assessment of Crystalline Photovoltaics in the Swiss Ecoinvent Database Prog. Photovolt: Res. Appl.,(13) 2005. pp. 429446.

KALTSCHMITT, M; ROSCH, C. \& DINKELBACH,L . Biomass Gasification in Europe. European Comission Report AIR3-CT-94-2284. Bruxelas: EC, 1998.

KALINCI, Y; HEPBASLI, A.\& DINCER, I. Biomasss-based Hydrogen Production: A Review and Analysis. International Journal of Hydrogen Energy 34, 2009. pp.8799- 8817 .

KHATIB, H. Energy Security. In World energy assessment; energy and the challenge of sustainability. United Nations Development Programme, United Nations Department of Economic and Social Affairs, Word Energy Council, 2000. pp. 111130.

KEOLEIAN, G. AND LEWIS, G. Application of life-cycle energy analysis to photovoltaic module design. Prog. Photovoltaics: Res. Appl. 5-4, 1997. pp. 287300.

KLÖPFFER, W. In defense of the cumulative energy demand (editorial). International Journal of Life Cycle Assessment $22,1997.61$ p. 
KOMIYAMAA H., MITSUMORI B T., YAMAJIC K., YAMADAD K. Assessment of Energy Systems by Using Biomass Plantation. Fuel 80, 2001. pp. 707- 715.

KOLLNER, T. Species-pool Effect Potentials (SPEP) as yardstick to evaluate land use impacts on biodiversity. Journal of Cleaner Production, 1999.

KOMP, R. J. Pratical Photovoltaics, Electricity from Solar Cells. Michigan; Aatec Publications, $2002.197 \mathrm{p}$.

KORONEOS, C, DOMPROS, A \& ROUMBAS, G. Hydrogen Production Via Biomass Gasification: a Life Cycle Assessment Approach. Chemical Engineering an Processing 47, 2008. pp. 1261-1268.

KORDESCH, K \& SIMADER, G. Fuel Cells and their Applications. Weinheim: New York; Basel; Cambridge: Tokyo: VCH, 1996. ISBN 3-527-28579-2. NE: Simader, Gunter. pp. 375.

LORA E. E.S., ANDRADE, R.V.,SANCHEZ,C,G.GOMEZ,E.O.SALES,C.A.V.B. Gaseificação. In. Biomassa para Energia. Cortez, L.A.B. Lora, E.S. Gomez, E. O. ( Org) Campinas, Editora da Unicamp, 2008.pp.241 -327.

LORENZO,E. Energy Collected and Delivered by PV Modules. In Luque, A. \& Hegedus, S.( Eds.).Handbook of Photovoltaic Science and Engineering, Wiley Chichester, 2003. pp.905-970.

MACEDO, I. C.; LEAL, M.R.L.V; DA SILVA, J.E.A.R. Balanço das emissões de gases do efeito estufa na produção e no uso do etanol no Brasil. Governo do Estado de São Paulo. Secretaria do Meio Ambiente. Abril, 2004.

McDENDRY, P. Energy production from Biomass ( part 1): overview of biomass. Bioresource Technology 83, 2002. pp $37-46$.

MANN, M.K.\& SPATH, P.L. Life Cycle Assessment of Biomass Gasification Combined-Cycle System. U.S Department of Energy:National Renewable Energy Laboratory, 1997. 
MANZINE, E. \& VEZZOLI, C. O Desenvolvimento de Produtos Sustentáveis. Trad. Carvalho, A. - 1 ed. São Paulo: Editora da Universidade de São Paulo, 2005. 366p.

MARTINS, F.R.; PEREIRA, E.B., SILVA, S.A.B., ABREU,S.L.COLLE,S. Solar Energy in Brazil, Part One, Resource Assessment. Energy Policy 36, 2008. pp. 2483 - 2854.MÉRIDA, W. MANESS, P. C., BROWN, R.C., LEVIN, D.B. Enhanced Hydrogen Production Indirectly Heated, Gasified Biomass, and Removal of Carbon Gas Emissions using a Novel Biological Reformer. International Journal of Hydrogen Energy, 29. 2004. pp. 283-290 .

MINISTÉRIO DA CIÊNCIA E TECNOLOGIA - MCT. Economia do Hidrogênio. Programa de Ciência, Tecnologia e Inovação para a Economia do Hidrogênio (ProH2). Disponível em http://www.mct.gov/index.php/content/view/4948.html?. Acesso em agosto de 2007.

MEENT, D. VAN DE, KLEPPER, O. Mapping the Potential Affected Fraction (PAF) of Species as an Indicator of Generic Toxic Stress. RIVM report 607504001, Bilthovem, June, 1997.

MURRAY, C.J.L; LOPEZ, A.D. \& JAMISON, D.T. The Global Burden of Disease in 1990: summary results, sensitive analysis and future directions. Bulletin of the Worls Health Organization, 72 (3), 1994. pp. 495-509.

MULLER-WENK. LAND -USE. The Main Threat to Species. IWOE Discussion Paper, no 64, IWOE University of St. Gallen, 1998.

NUSSBAUMER, T. \& OSER, M. Evaluation of Biomass Combustion based Energy Systems by Cumulative Energy Demand and Energy Yield Coefficient, International Energy Agency IEA Bioenergy Task 32 and Swiss Federal Office of Energy, Verenum press, Version 1.0, Zurich, January 2004.

NATIONAL RENEWABLE ENERGY LABORATORY. New Horizons for Hydrogen: Producing Hydrogen from Renewable Sources. Research Review, 2003. 
OCDE/IEA. Organization for Economic Co-operation and Development - OCDE/ International Energy Agency -IEA. Renewable for Power Generation: Status and Prospects. Paris, 2003. pp. 53-73.

PEHNT, M. Life Cycle Assessment of Fuel Cell Stacks. International Association for Hydrogen Energy. Elsevier Science Ltda, 2001. pp. 91 - 101.

PEREIRA, E.B., MARTINS,F.R.,DE ABREU,S.L \& RUTHER, R.. Atlas Brasileiro de Energia Solar. São José dos Campos: INPE, 2006. 64 p.

PEREZ, R., AGUiAR, R. COLlaReS-PEREIRA, M. DIUMATIER, D., ESTRAdACAJIGAL,V. et. al. Solar Resource Assessment: A review. In Gordon. J. (Ed) Solar Energ: The State fo Art, James \& James, London, 2001.

PERRY, R. H. \& CHILTON, C. H. Chemical Engineers Handbook, 5 ed. Nova York: McGraw-Hill Book Co., 1973.

PRASAD, D \& SNOW, M. Designing with Solar Power: a source book for building integrated photovoltaics (BiPV). London: Earthscan, 2005. 252 p.

PRÉ CONSULTANTS - Goedkoop, M. \& Oele Michele. SimaPro 6: Introducción a LCA con SimaPro. Pré Consultants, 2004. 81p.

PILKINGTON, A. HURLEY, F. DONNAN, P. Health Effects in ExternE Transport: Assessment and Exposure -Response Functions. Institute of Occupational Medicine, Edinburgh. July, 1997.

QUAAK , P. KNOEF, H. STASSEN, H. Energy from Biomass: A Review of Combustion and Gasification Technologies. Washington DC: Word Bank Technical Paper, no 422 - Energy Series, 1998. 78 p.

RAUGEI, M. AND FRANKL, PAOLO. Life cycle impacts and costs of photovoltaics: current state of the art and future outlooks. Energy, 34, 2009. pp. 392-399. 
REEDY, A.K.N. et. al. Energy and Social Issues. In: World Energy Assessment: Energy and the Challenge of Sustainability. GOLDEMBERG, J. (Editor). UNDP: Washington, D.C, 2000. pp.41-58.

REIS, L. B. \& SILVEIRA. S. Energia Elétrica para o Desenvolvimento Sustentável. 2 ed. - São Paulo: Editora da Universidade de São Paulo, 2001. (Acadêmica; 27).

REIS, L.B.; FADIGAS, E. A. A. \& CARVALHO, C. E. Energia, Recursos Naturais e a Prática do Desenvolvimento Sustentável. - Barueri, SP. Manole, 2005. 415 p.

REED, T. Biomass Gasification: Principles and Technology. Park Ridge, N.J., Noyes Data Corp ,1981.

ROGNER, H.H \& POPESCU, A. An Introduction to Energy. In: World Energy Assessment: Energy and the Challenge of Sustainability. GOLDEMBERG, J. (Editor). UNDP: Washington, D.C, 2000. pp. 31-37.

SCHAEFER, H. \& HAGERDON, G.Hidden. Energy and Correlated Environmental Characteristics of PV Power Generation. Renewable Energy, Vol.2., No. 2, 1992. pp156-166.

SCHWARZ, U. \& KELLER, M. ERZ and OPRZ einer 3 KW Photovoltaikanlange. Semesteralbeit. Eth, Zurich. 1992

SANDVIG, E., G. WALLING, D. E. DAUGAARD, R. J. PLETKA, D. RADLEIN, W. JOHNSON AND R.C. BROWN (2004). The prospects for integrating fast pyrolysis into biomass power systems. International Journal of Power and Energy Systems 24(3), 2004: pp. 228-238.

SPATH, P. L. AND D. C. DAYTON. Preliminary Screening - Technical and Economic Assessment of Synthesis Gas to Fuels and Chemicals with Emphasis on the Potential for Biomass-Derived Syngas. Golden, Colorado, National Renewable Energy Laboratory, 2003. 
SOLLI, C. Fissil or Fossil: a Comparative Hybrid Life cycle Assessment of Two Different Hydrogen Production Methods. Master thesis. Norwegian University of Science and Technology, 2004. 43p.

SORESEN, B. Total life cycle assessment of PEM fuel cell car. Report, Energy and Environment Group. Roskilde University Denmark, 2004

SORESEN, B. Hydrogen and Fuel Cells: emerging Technologies and applications. Energy and Environment Group. Roskilde University Denmark, 2005

TAMPIER, M., SMITH, D.;BIBEAU,E.;BEAUCHEMIN, P. Identifying environmentally preferable uses for biomass resources. Canada: Envirochem Services Inc. 2004, 123p.

TANG, Z.G.,MA,P.Y.,CHENG,J.P.,LI,Y.L.\& LIN, Q.Z. A Novel Biomass Gasifier for Producing Tar-Free and Hydrogen-Rich Syngas. Advanced Materials Reseach Vols. 105-105, 2010. pp.709-712.

TSUO, Y.S.; GEE, J.M; MENNA,P. STREBKOV, D.S.;PINOV, A. \& ZADDE, V. Environmentally Benign Silicon Solar Cell Manufacturing. In. Shcmid and others (ED) Proceedings of the Second World Conference on PV Solar Energy Conversion. Report EUR 18656. Brussels.

TILLMAN, A.M. \& BAUMANN, H. General Description of Life Cycle Assessment Methodology. Estocolmo: Chalmers University of Technology, 1995.

TOMPSON, M. ,ELLIS, R. WIDAVSKY, A. Cultural Theory. West Print Boulder, 1990.

TURKENBURG, W.C. Renewable Energy Technologies. World Energy Assessment: Energy and the Challenge of Sustainability. GOLDEMBERG, J. (Editor). UNDP: Washington, D.C, 2000. pp.222-247.

UNEP/ SETAC - UNIDET NATIONS ENVIRONMENT PROGRAME. Life Cycle Approaches. The road from analysis to practice. Division of Technology, Industry and Economics (DTIE). Production and Consumption Unit. Paris: France. 89p. 
UNITED NATIONS DEVELOPMENT PROGRAMME - UNDP. Energy after Rio: Prospects and Challenges. In collaboration with International Energy Initiative, Stockholm Environment Institute and United Conference on Environment and Development. UNDP: New York, 1997.

UNITED NATIONS DEVELOPMENT PROGRAMME - UNDP/UNITED NATIONS DEPARTMENT OF ECONOMIC AND SOCIAL AFFAIRS - WORLD ENERGY COUNCIL. World Energy Assessment: Energy and the Challenge of Sustainability. GOLDEMBERG, J. (Editor). UNDP: Washington, D.C, 2000. 508 p.

UTGIKAR, V. \& THIESEN, T. Life Cycle Assessment of High Temperature Electrolysis for Hydrogen Production via Nuclear Energy. International Journal of Hydrogen Energy 31, 2006. pp. 939-944.

ZINI, G. \& TARTARINI,P. Hybrid Systems for Solar Hydrogen: a Selection of CaseStudies. Applied Thermal Engineering, 29, 2009. pp.2585-2595.

WALTER, A., FAAIJ, A. BAUEN, A.. A produção da Eletricidade a partir da Biomassa. In: Uso da Biomassa para a Produção na Indústria Brasileira. ROSILLOCALLE, F., BAJAY, S. V. \& ROTHMAN, H. (ORG); tradutores ROCHA, J. D. \& ROCHA, M. P. G. D. - Campinas, SP: Editora da UNICAMP, 2005, 447p.

WALTER, A. \& NOGUEIRA, L.A.H. Sistemas de Produção de Eletricidade a partir da Biomassa. In. Biomassa para Energia. Cortez, L.A.B. Lora, E.S. Gomez, E. O. ( Org) Campinas, Editora da Unicamp, 2008. pp.575 -631.

WENHAM, S. R., GREEN, M.A.; WATT, M.E. \& CORKISH, R. Applied Photovoltaics. United Kingdom: Earthscan, 2009. 319 p.

WIERTZ,J. Van DJIK \& LATOUR, J.B. Vegetatie-module, de kans op voorkomen van 7000 plantersoorten als functie van vocht, ph, nutrient en zout. RIVM rapport, n711901006. Bilthoven, 1992.

WILSON, R. AND YOUNG, A. Embodied energy payback period of photovoltaic installations applied to buildings in the UK. Build. Environ. 314 1996. pp. 299305. 
WORDEN, R. M., A. J. GRETHLEIN, M. K. JAIN AND R. DATTA. Production of butanol and ethanol from synthesis gas via fermentation. Fuel 70(5): 1991615-619. 